\title{
Chemical Composition of
}

\section{Bulk Precipitation in the}

North-Central and

Northeastern United States,

December 1980 Through

\section{February 1981}



GEOLOGICAL SURVEY CIRCULAR 874 



\section{Chemical Composition of Bulk Precipitation in the North-Central and Northeastern United States, December 1980 Through February 1981}

By Norman E. Peters and Joseph E. Bonelli

Geological Survey Circular 874 


\title{
United States Department of the Interior \\ WILLIAM P. CLARK, Secretary
}

\author{
Geological Survey \\ Dallas L. Peck, Director
}

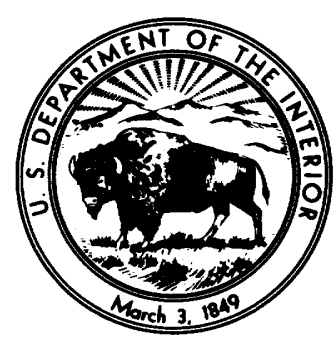

First printing 1982

Second printing 1982

Third printing 1984

Library of Congress Cataloging in Publication Data

Peters, Norman E.

Chemical composition of bulk precipitation in the north-central and northeastern United States, December 1980 through February 1981

(Geological Survey circular ; 874)

Bibliography: $p$.

1. Precipitation (Meteorology)-Middle West-Analysis. 2. Precipitation (Meteorology)-Northeastern States-Analysis. I. Bonelli, Joseph E. II. Title. III. Series.

QE75.C5 no. 874 557.3s 82-600116

[QC925.1.U8A14] [551.57'71] 


\section{CONTENTS}

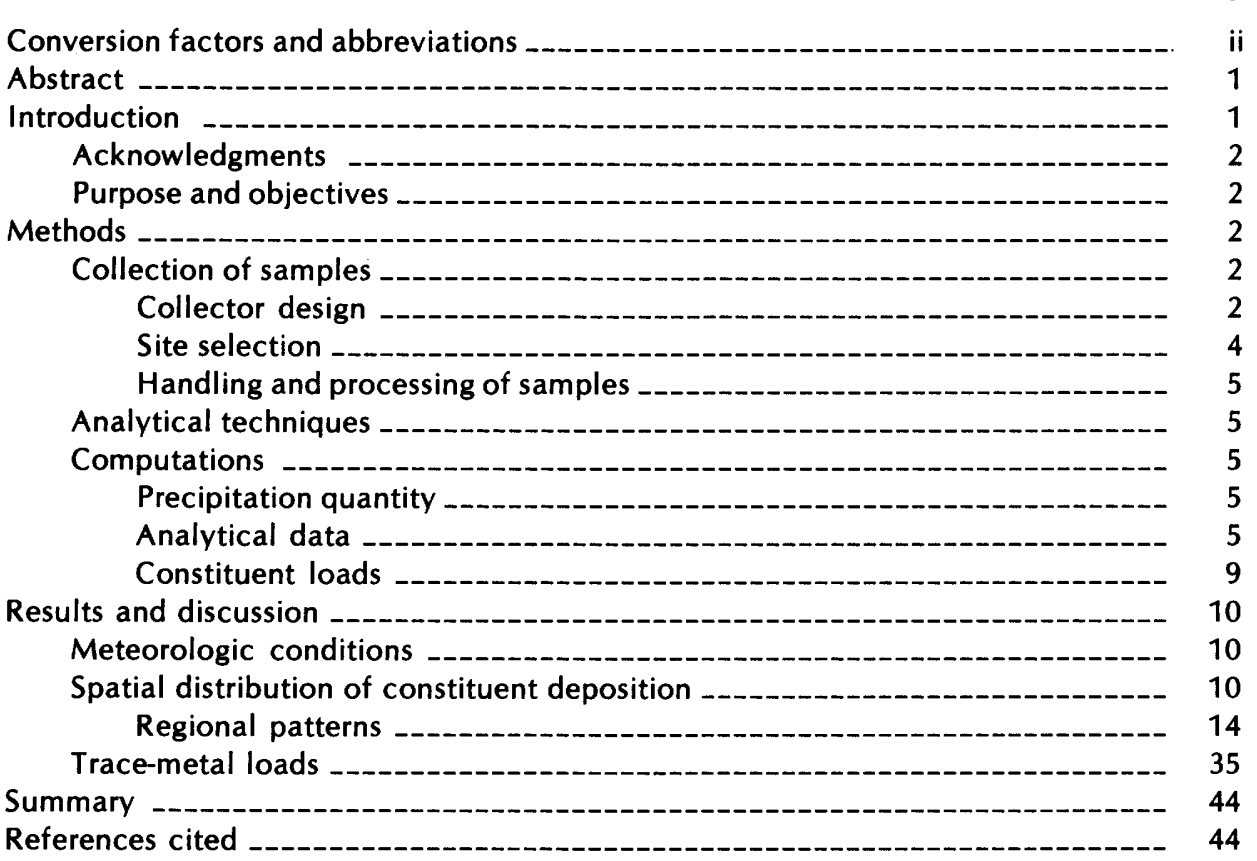

Tables

Table 1. Techniques and methods for chemical analyses of bulk-precipitation and snow-core samples

Page

2. Statistical summary of dissolved chemical concentrations in the bulkprecipitation samples

3. Deposition of lead, copper, nickel, zinc, cadmium, manganese, and iron in bulk precipitation

4. Descriptions of bulk-precipitation-collection sites

5. Dissolved chemical constituent concentrations of bulk-precipitation samples

\section{Illustrations}

Figure 1. Map showing location of sampling sites

2. Photograph of typical bulk-precipitation collectors used in this study ----

3. Graph showing cation vs. anion equivalents of all bulk-precipitation samples

4. Graph of precipitation quantity recorded vs. quantity collected --.---_--

5. Maps showing air-temperature departures and percentage of normal precipitation, December 1980 through February 1981 .-.--_-----

6. Maps showing mean monthly 700-millibar pressure surface, December 1980 through February 1981

7. Map showing average surface-wind patterns over the North-Central and Northeastern United States, December 1980 through February 1981 _

8. Map and histogram showing distribution of precipitation 


\section{Illustrations}

9-20. Maps with histograms showing concentration and daily loads of dissolved constituents in bulk samples:

9. Sodium -

10. Chloride --_-_- 20

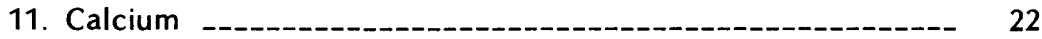

12. Fluoride --_-_-

13. Sulfate --_-_-_-_- 26

14. Hydrogen ion --_-_-_-_- 28

15. Nitrate -

16. Lead --_-

17. Ammonium _._- 36

18. Iron -

19. Strontium --_-_-_-_-_-_-_-_-_- 40

20. Manganese -

\section{CONVERSION FACTORS AND ABBREVIATIONS}

The following factors may be used to convert the International System (SI) of metric units of measure used in this report to inch-pound units.

\begin{tabular}{|c|c|c|}
\hline Multiply SI units & by & To obtain inch-pound units \\
\hline \multicolumn{3}{|c|}{ Length } \\
\hline $\begin{array}{l}\text { micrometer }(\mathrm{mm}) \\
\text { millimeter }(\mathrm{mm}) \\
\text { centimeter }(\mathrm{cm}) \\
\text { meter }(\mathrm{m}) \\
\text { kilometer }(\mathrm{km})\end{array}$ & $\begin{array}{l}0.0000394 \\
.0394 \\
.394 \\
3.28 \\
.6214 \\
\end{array}$ & $\begin{array}{l}\text { inch (in) } \\
\text { inch (in) } \\
\text { inch (in) } \\
\text { foot (ft) } \\
\text { mile (mi) }\end{array}$ \\
\hline \multicolumn{3}{|c|}{ Area } \\
\hline $\begin{array}{l}\text { square kilometer }\left(\mathrm{km}^{2}\right) \\
\text { square meter }\left(\mathrm{m}^{2}\right)\end{array}$ & $\begin{array}{l}0.3861 \\
10.76\end{array}$ & $\begin{array}{l}\text { square mile }\left(\mathrm{mi}^{2}\right) \\
\text { square foot }\left(\mathrm{ft}^{2}\right)\end{array}$ \\
\hline \multicolumn{3}{|c|}{ Volume } \\
\hline $\begin{array}{l}\text { liter }(\mathrm{L}) \\
\text { milliliter }(\mathrm{mL})\end{array}$ & $\begin{array}{r}0.2642 \\
.0610 \\
\end{array}$ & $\begin{array}{l}\text { gallon (gal) } \\
\text { cubic inches }\left(\mathrm{in}^{3}\right)\end{array}$ \\
\hline \multicolumn{3}{|c|}{ Mass } \\
\hline $\operatorname{gram}(\mathrm{g})$ & 0.0353 & ounces (oz) \\
\hline \multicolumn{3}{|c|}{ Other abbreviations used in this report } \\
\hline
\end{tabular}

meq/L, milliequivalent per liter

$\mathrm{mmho} / \mathrm{cm}$ at $25^{\circ} \mathrm{C}$, micromho per centimeter at $25^{\circ}$ Celsius

$\mathrm{mm} / \mathrm{d}$, millimeter per day

$\mathrm{mg} / \mathrm{L}$, milligram per liter

$\mathrm{mg} / \mathrm{L}$, microgram per liter

$\mathrm{mm}$, micrometer

$\mathrm{mg} / \mathrm{m}^{2}$, milligram per square meter

$\mathrm{mg} / \mathrm{m}^{2}$, microgram per square meter

$\mathrm{mb}$, millibar 


\title{
Chemical Composition of Bulk Precipitation in the North-Central and Northeastern United States, December 1980 Through February 1981
}

\author{
By \\ Norman E. Peters and Joseph E. Bonelli
}

\begin{abstract}
Samples of bulk precipitation were collected at 179 sites in the North-Central and Northeastern United States for 3 months during the winter of 1980-81 to provide data on the distribution of chemical constituents. Concentrations and average daily loads of 29 dissolved constituents were determined. Sodium and chloride deposition was relatively high in coastal areas and adjacent to some urban centers. Regional patterns of the daily loads of hydrogen ion, nitrate, lead, and iron correlate well with one another and form a concentric pattern around a center of high deposition in eastern Ohio and western Pennsylvania, which suggests an urban-industrial source. Samples from this area had a low $\mathrm{pH}(<4.2)$, whereas samples from southern Minnesota and Illinois had a more neutral $\mathrm{pH}(>5.6)$. The latter samples had high concentrations of both calcium and total inorganic carbon, which suggests $\mathrm{pH}$ control by soil-derived carbonate minerals. Deposition patterns of ammonium, nitrate, and sulfate display regional highs in Illinois, Indiana, and southwestern Michigan, which suggest agricultural sources such as fertilizer. Median loads of zinc, iron, and lead were lower than reported in previous studies for North America. The apparent decrease in lead from earlier levels throughout the area studied may be attributed to reduced consumption of leaded fuels and to lower deposition in winter.
\end{abstract}

\section{INTRODUCTION}

Much has been written about "acid rain" and its effects in the Northeastern United States and elsewhere, and many hypotheses have been formulated about both its sources and its geographic distribution (Likens, 1976; Babich and others, 1980; Hileman, 1981). Most of the substances that contribute to acid rain are formed within the atmosphere through hydrolysis of the oxidized forms of nitrogen oxides and sulfur oxides (a major source of these is the combustion of fossil fuels) and are deposited with rain and snow (Galloway and others, 1976). Acid atmos- pheric precipitation has been defined as rain or snow having a pH of less than 5.6, the value of pure water in equilibrium with ambient levels of atmospheric carbon dioxide.

Considerable concern also has arisen over the release of other contaminants to the atmosphere and their subsequent deposition, particularly those that are known to be toxic. Regional patterns of chemical deposition can delineate major source areas of atmospheric contaminants and indicate the direction of transport from those sources.

Atmospheric deposition may be divided into two parts: the wet component and the dry component. The wet component includes rain, snow, dew, and hail; the dry component includes fine to intermediate particles that are deposited by impact on a surface, gases that are adsorbed or absorbed by surfaces, and relatively large or heavy particles that settle from the atmosphere by gravity and are commonly caught on horizontal surfaces. No commonly accepted methods exist for measuring the impaction load or the sorbed gases that are deposited on surfaces, but dustfall collectors have been used for many years to collect what is assumed to represent the gravity component of dry deposition (Galloway and Likens, 1978). This method has certain shortcomings, in that such collectors do not allow for resuspension of the dustfall in the manner of other surfaces and the dustfall frequently contains a high proportion of locally derived material that overwhelms the part transported from longer distances. This is especially true during the growing season. During winter, however, when the ground is frozen or covered by snow and deciduous plants have lost their leaves, dustfall contains lesser amounts of local litter and consists largely of material that has been transported longer distances. 
In general, interpreting the composition of bulk precipitation (the combination of dustfall and wet deposition in an open container) is difficult because substances borne in the wet component cannot be distinguished from those borne in the dustfall. If the collectors receive much locally derived dry material, bulk precipitation is a poor source of data for determining areal deposition patterns. Yet, if it is infeasible to collect separate samples of wet deposition and dustfall, bulk precipitation may be the only recourse. If collection is done during winter, when the ground is frozen or covered with snow, the amount of locally derived dustfall will be minimal, and bulkprecipitation samples collected over a 3-month period should represent the composition of atmospheric deposition within the region. If the collectors are located according to uniform criteria, results should indicate areas in which the greatest loads of airborne chemical constituents are being deposited.

\section{ACKNOWLEDGMENTS}

The authors thank U.S. Geological Survey fieldoffice personnel for continued cooperation and assistance, without which a project of this scope could not have been made. Thanks also are extended to personnel of the Atmospheric Sciences Research Center of the State University of New York at Albany for the collection of samples from the Whiteface Mountain event site, to personnel from the Rensselaer Polytechnic Institute, Troy, N.Y., for collection of samples from the Old Forge, N.Y., event site, and to personnel from Pennsylvania State University, State College, Pa., for collection of samples from the Pennsylvania event site.

Samples were processed and analyzed by the U.S. Geological Survey National Water Quality Laboratory in Denver, Colo. Herman Feltz, Northeastern Region staff member, coordinated the 1980-81 snow-chemistry study; Vance C. Kennedy and Howard E. Taylor, National Research Program, conceived the project and provided guidance.

To the many individuals whose work is represented here, we express our gratitude.

\section{Purpose ANd Objectives}

The snow-chemistry reconnaissance was designed to provide information on the regional distribution of chemical constituents in bulk precipitation over the North-Central and North- eastern United States. In addition to collecting bulk precipitation, cores of the snowpack were taken at selected sites for comparison of their chemical composition with that of the bulk samples. All precipitation samples and snowpack cores were filtered, and the residue from select sites currently (1982) is being analyzed for chemical and mineral composition to determine its effect on the liquid fraction of the samples.

This report describes the areal distribution of some of the dissolved constituents in bulkprecipitation samples. Samples were collected throughout the North-Central and Northeastern United States from about December 1, 1980, through February 1981. Also, the report examines regional patterns of loading of selected constitutents in relation to possible source areas.

\section{METHODS}

\section{COLLeCTION OF SAMPLES}

Samples of bulk precipitation as well as snowpack cores were collected during the winter of 1980-81. Primary bulk-precipitation collectors were installed at 189 sites from Maine to Minnesota and from the Canadian border south to the Ohio River valley (fig. 1). Each site represents about $6,500 \mathrm{~km}^{2}$. At 21 of the sites, both a primary and a replicate collector were installed. At 15 of the sites, both a primary and an event collector were installed; 12 of these also had a replicate collector.

All collectors were installed on or about December 1,1980 , and the primary and replicate collectors were sampled on or about March 1 , 1981. (Samples were recovered from only 179 sites because at the remaining 10 sites either collectors were vandalized or samples were lost.) The event collectors were sampled four times (every 3 weeks) during this period. Snow cores were to be taken at approximately 10 percent of the sites at the time of bulk-sample collection, but, on the collection date, snow cover was insufficient for sampling at all but five sites.

\section{Collector Design}

The collectors (fig. 2) consisted of a $170-\mathrm{cm}$ length of relatively inexpensive thick-walled fiber tubing of $45.7-\mathrm{cm}$ inside diameter, the type generally used as a form for concrete footings and pillars. The tube was enclosed in a $46.3-\mathrm{cm}$ diameter pol yethylene bag that was folded over the top of the tube and taped to the inside to 


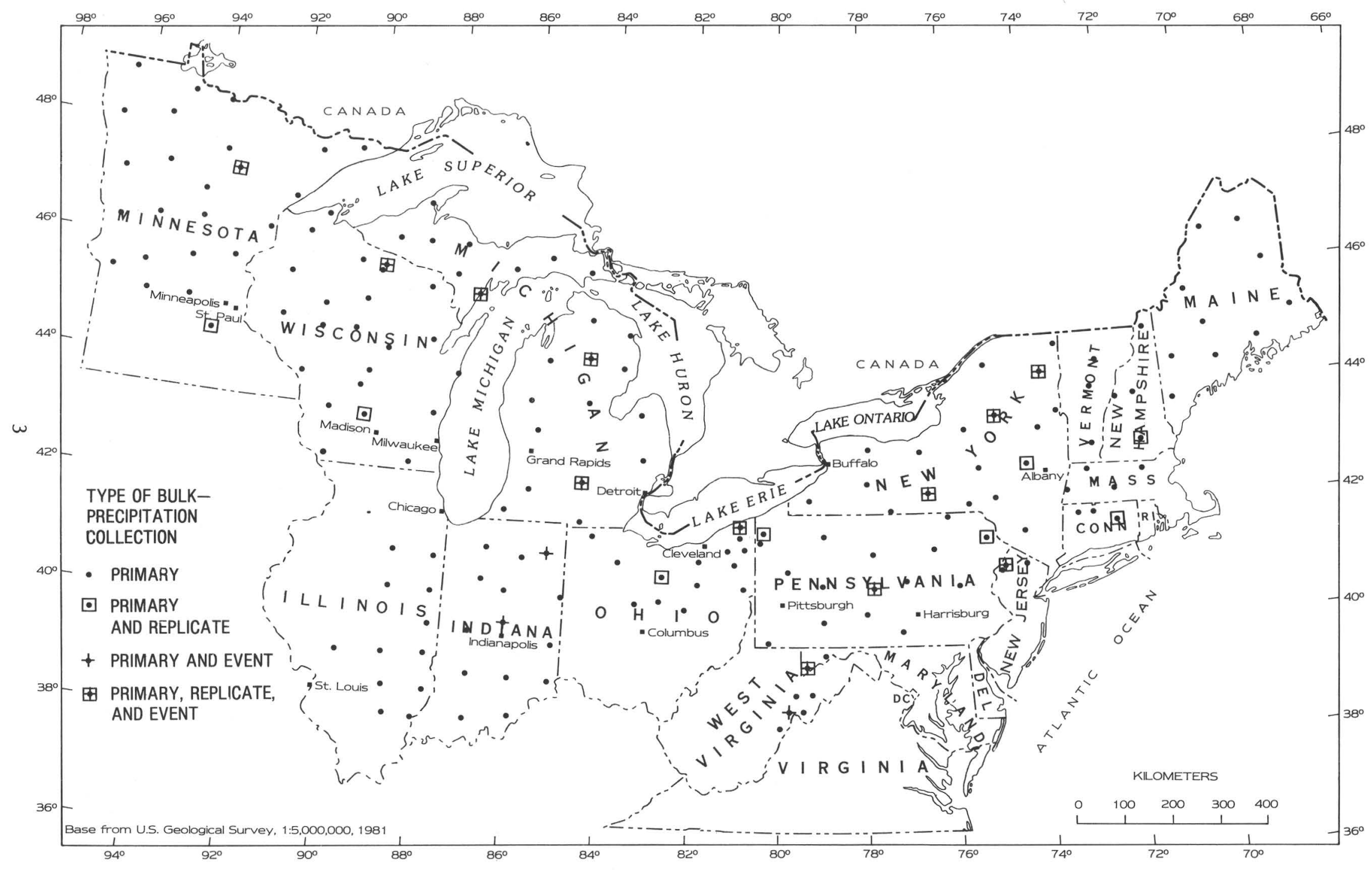

FIGURE 1. - Location of sampling sites, winter 1980-81. 


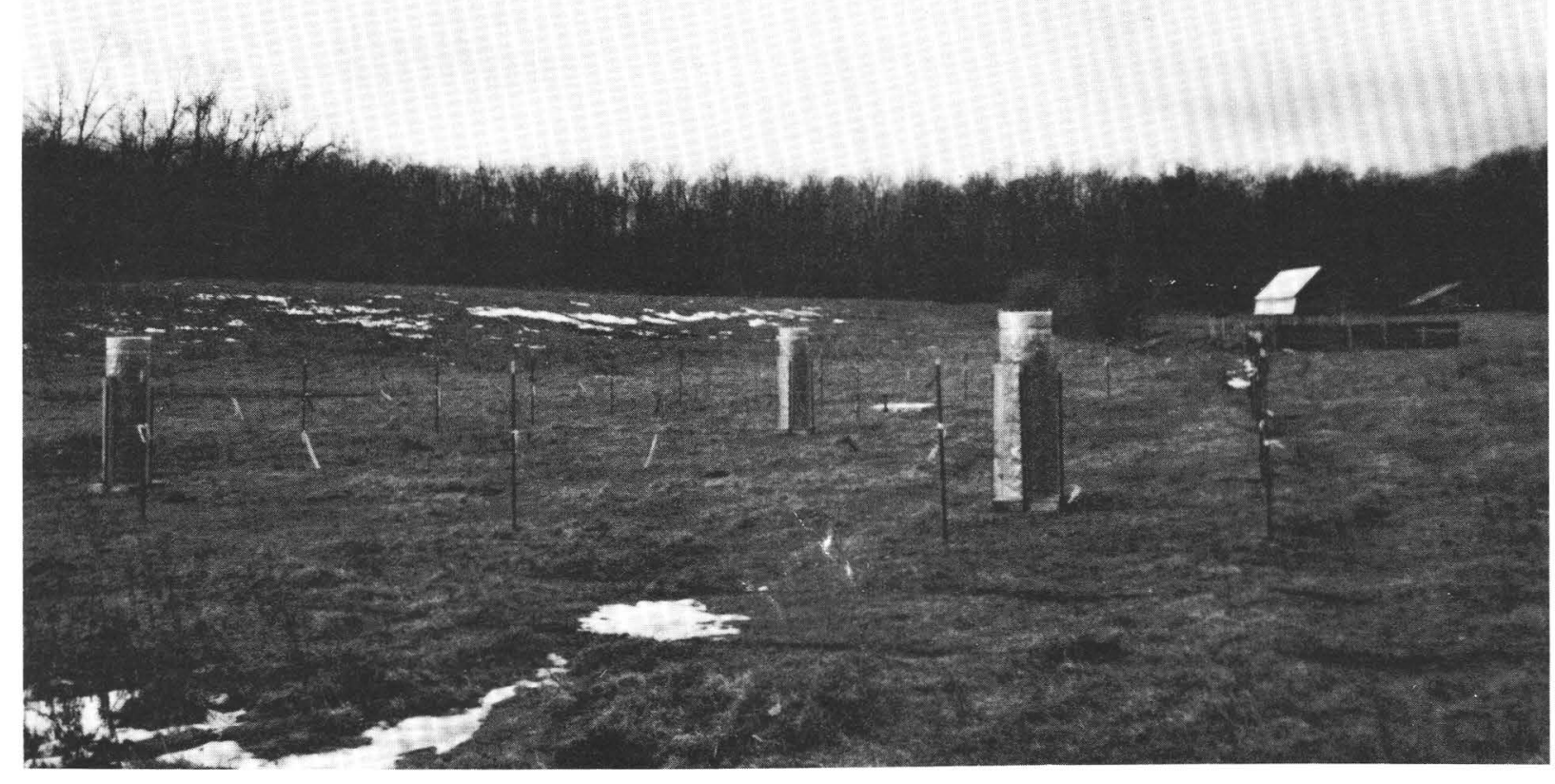

FIGURE 2. - Typical bulk-precipitation collectors used in this study.

prevent moisture from softening and decomposing the fiber. Two polyethylene bags (one inside the other) were placed inside the tube, the inner for sample collection and the outer to retain the sample should the inner bag leak. A bird deterrent consisting of inverted garden-border fencing (vinyl-coated wire) was wrapped around the top of the collector with the prongs about 4 $\mathrm{cm}$ apart and extending $7 \mathrm{~cm}$ above the top of the collector. The assembly was mounted on a $50-\mathrm{cm}$ square of $1.3-\mathrm{cm}$ plywood and strapped between supporting metal fenceposts.

The snowpack was sampled with prewashed Adirondack snow-coring equipment consisting of a $150-\mathrm{cm}$ depth-graduated fiberglass tube with a 16.7-cm diameter stainless steel cutting head and a spring scale calibrated for water content. Snow cores were taken on a $120-\mathrm{cm}$ square sheet of $1.3-\mathrm{cm}$ plywood that was covered with $0.152-\mathrm{mm}$ polyethylene sheeting and placed on the ground $5 \mathrm{~m}$ upwind from the bulk collectors. The purpose of the sampling platform was to prevent contamination of the snowpack from underlying soils and vegetation.

\section{Site Selection}

Because the study was designed to assess the regional character of atmospheric deposition, considerable effort was made to avoid local contamination. A major criterion for site selection was to avoid proximity to sources such as highways, chimneys, barnyards, and vegetation. Most collectors were placed off seldom-traveled secondary paved roads at least $0.5 \mathrm{~km}$ downwind from any frequently used dirt road, $300 \mathrm{~m}$ from any known point source of contamination, and separated from the nearest vegetation by a distance equivalent to six times the height of the vegetation. Areas of excessive snow drifting were avoided to ensure uniform settling of the snow in to the collector. Locations on northern slopes were sought to maximize snow cover and minimize melting, particularly in the southern part of the study area.

Regional site-selection criteria consisted simply of avoiding najor contamination sources such as cities, industrial plants, and coal- and oil-fired powerplants; therefore, collectors were placed at 
least $25 \mathrm{~km}$ downwind from these sources. Because collection of local soil and organic particulates was to be avoided, collectors were located, if possible, where snow was expected to cover the ground for at least 60 percent of the collection period, based on long-term records. General characteristics of each site are listed in table 4 (following "References Cited").

\section{Handling and Processing of Samples}

Event sample bags were removed and replaced with new bags on three occasions at approximately 3-week intervals during the collection period. These samples were stored at a maximum temperature of $4^{\circ} \mathrm{C}$ until the final samples were collected. At the end of the collection period, bags containing the bulk samples and bags containing the snowpack cores were chilled and transported to field laboratories for processing. All samples were filtered under pressure through a $0.2-\mu \mathrm{m}$ Nuclepore' polycarbonate "aerosol membrane" filter, a type chosen for its low trace-element content.

Many of the samples contained sufficient solid material to require more than one filter. A small part of the filtrate of each sample was used to rinse three precleaned $1-\mathrm{L}$ polyethylene bottles and one $250-\mathrm{mL}$ Teflon bottle. After the four bottles for each sample were filled, the remainder of the sample was filtered, weighed, and discarded. The four bottles from each site and the respective filters were shipped on ice to the Geological Survey's National Water Quality Laboratory in Denver, Colo. Before chemical analysis, the sample in the acid-rinsed polyethlyene bottle was acidified with $1.0 \mathrm{~mL}$ of concentrated (15.5 molar) ultrapure nitric acid. To minimize chemical changes during sample handling and storage, particularly those produced by biological activity, all samples were kept at $4^{\circ} \mathrm{C}$.

Analytical determinations began approximately 2 months after the first samples were collected and processed. The acidified samples were analyzed for trace elements and metals; the unacidified samples were analyzed for other constituents or properties.

\section{ANALYTICAL TECHNIQUES}

All filtered liquid samples were analyzed for the suite of 28 constituents plus specific conductance and $\mathrm{pH}$, provided sufficient sample was

\footnotetext{
'The use of brand names in this report is for identification purposes and does not imply endorsement by the U.S. Geological Survey.
}

available. A variety of analytical techniques were used; the selection of techniques and methods for each determination was based on their suitability for concentration levels anticipated. Techniques and methods used for determining each constituent or property, the lower detection limits, and the published reference for each are given in table 1 . These techniques and methods are generally those used daily in the Geological Survey's National Water Quality Laboratories.

\section{COMPUTATIONS}

\section{Precipitation Quantity}

The quantity of precipitation (rain, snow, and so forth) at each site during the collection period was estimated by summing the daily precipitation recorded at nearby precipitation gages of the $\mathrm{Na}$ tional Weather Service (U.S. National Oceanic and Atmospheric Administration, 1980-81). If no precipitation gage was nearby, data from several adjacent National Weather Service gages at elevations comparable to those at the sampling site were averaged. Also, the volume of sample collected at many sites was inferred from the sample weight. Discrepancies between calculated and measured volume were treated as described below.

\section{Analytical Data}

Chemical concentrations were calculated from calibration curves generated with laboratory standards. Although field blanks were not obtained, possible contamination by the collection bags was estimated from blanks obtained by rinsing bags with reagent water. The concentrations of constitutents in the blank samples were almost always at or below the analytical limit of detection (table 2).

Ceneral estimates of the sampling precision associated with the collectors and the analytical precision associated with the respective determinations were calculated. For each site at which both a primary and a replicate sample were collected, the absolute value of the difference between the respective concentrations (above detection limit) was divided by the mean of the two and expressed as a percentage. Similarly, 43 of the samples were split and analyzed along with the other bulk samples; the splits were identified with different laboratory codes. Estimates of precision for these split determinations were calculated in the same way as those from the replicate collectors. These two precision estimates, 


\begin{tabular}{|c|c|c|c|c|}
\hline $\begin{array}{l}\text { Constituent } \\
\text { or property }\end{array}$ & Technique $^{*}$ & Methodt & $\begin{array}{c}\text { Detection } \\
\text { limit } \\
\text { (microgram } \\
\text { per liter) }\end{array}$ & Reference \\
\hline As & AA _. & h.g -- & 0.1 & Skougstad and others, 1979, p. 65 \\
\hline $\mathrm{Ba}$ & ICP & d.a & 2 & Garbarino and Taylor, 1979 \\
\hline $\mathrm{Be}-\mathrm{C}_{-1}$ & $\bar{s}-----d o_{-----}$ & ------do_----- & .5 & Do. \\
\hline $\begin{array}{l}\text { Total inorganic } \\
\text { carbon. }\end{array}$ & S - - - - - - & $a_{-\ldots}$ & 200 & Do. \\
\hline $\mathrm{Ca}$ & ICP & d.a & 20 & Do. \\
\hline $\mathrm{Cd}$ & -_-_-_do_-_-_- & _._._-_do___._- & 1 & Do. \\
\hline $\mathrm{Cl}$ & IC & d. $\mathrm{i}$ & 50 & Fishman and Pyen, 1979 \\
\hline Co & ICP & d.a & 3 & Garbarino and Taylor, 1979 \\
\hline $\mathrm{Cu}$ & ----- do_--_-- & -...... do & 10 & Do. \\
\hline F & IC & d.i & 50 & Fishman and Pyen, 1979 \\
\hline $\mathrm{Fe}$ & $\mathrm{ICP}$ & d. a & 3 & Garbarino and Taylor, 1979 \\
\hline$H(p H)$ & E & g.e -------- & & Skougstad and others, 1979, p. 543 \\
\hline $\mathrm{Hg}--1-1-0-1$ & $\mathrm{AA}$ & C.V & .1 & Skougstad and others, 1979, p. 197 \\
\hline K - - - - - - - & $---1--d$ do_-_--- & d.a & 100 & Skougstad and others, 1979, p. 229 \\
\hline 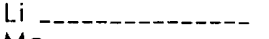 & ICP & $-\ldots$ do & 4 & Garbarino and Taylor, 1979 \\
\hline Mg & -_-_-_do_-_--- & --.--- do & 100 & Do. \\
\hline Mn & s----do_----- & --_--- do_----- & 1 & Do. \\
\hline $\mathrm{NH}_{4}-\mathrm{N}$ & $S_{--1----}$ & C & 10 & Skougstad and others, 1979, p. 415 \\
\hline $\mathrm{NO}_{3}-\mathrm{N}$ & 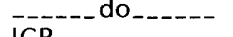 & $----\mathrm{do}_{---\ldots-}$ & 100 & Skougstad and others, 1979 , p. 445 \\
\hline $\mathrm{Na}-----------$ & ICP ---------- & d.a & 200 & Garbarino and Taylor, 1979 \\
\hline $\begin{array}{l}\mathrm{Ni} \\
\mathrm{Ph}\end{array}$ & AA --- & c.e - - - & 1 & Skougstad and others, 1979 , p. 215 \\
\hline $\mathrm{Pb}$ & ------ do & ----- do_-_-_- & 1 & Skougstad and others, 1979, p. 167 \\
\hline 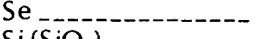 & $--n \mathrm{do}_{--n}$ & h.g --n----- & 1 & Skougstad and others, 1979, p. 237 \\
\hline $\mathrm{Si}\left(\mathrm{SiO}_{2}\right) \ldots$ & ICP & d.a & 9 & Garbarino and Taylor, 1979 \\
\hline $\begin{array}{l}\text { Specific } \\
\text { conductance. }\end{array}$ & E - --------- & 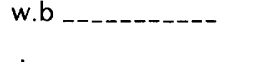 & & Skougstad and others, 1979, p. 545 \\
\hline 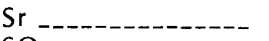 & ICP & d.a & .5 & Garbarino and Taylor, 1979 \\
\hline $\mathrm{SO}_{4}$ & IC & d. $\mathrm{i}$ & 100 & Skougstad and others, 1979 \\
\hline V - - - - - - - - - - - & ICP & d.a & 6 & Garbarino and Taylor, 1979 \\
\hline Zn & ------ do_------ & ------_do do $_{-----}$ & 3 & Do. \\
\hline \multicolumn{3}{|c|}{$\begin{array}{l}\text { * AA Atomic absorption spectrometry. } \\
\text { E Electrometry. } \\
\text { IC Ion chromatography. }\end{array}$} & 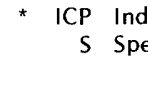 & $\begin{array}{l}\text { vely coupled plasma atomic emission spectrometry. } \\
\text { photometry. }\end{array}$ \\
\hline \multirow{2}{*}{\multicolumn{3}{|c|}{ c.e. Chelation extra }} & \multirow{2}{*}{$\begin{aligned}+ \text { d.a. } & \mathrm{Di} \\
\text { d.i. } & \mathrm{Di} \\
\text { g.e. } & \text { Lo } \\
\text { h.g. } & \mathrm{Au} \\
\text { w.b. } & \text { W }\end{aligned}$} & $\begin{array}{l}\text { aspiration into flame or plasma. } \\
\text { injection. }\end{array}$ \\
\hline & & & & $\begin{array}{l}\text { onductivity glass electrode. } \\
\text { lated hydride generation before thermal decomposition. } \\
\text { stone bridge. }\end{array}$ \\
\hline
\end{tabular}

$¥$ Detection limits are those specified in references attainable under prevailing analytical conditions.

one representing sampling plus analytical error and the other representing analytical error range from 0 to 200 depending on the constituent (table 2). Of these two potential sources of imprecision (sampling plus analytical and analytical), that associated with the analytical determinations was generally the lesser. In this report, contour maps are given only for those constituents from the primary collectors in which the median percentage error of both precision estimators was less than 50 . The concentration intervals on the maps were chosen to reflect consideration of the two precision estimators.

In addition, an estimate of sampling precision associated with sample preservation was calculated. The constituent loads for event samples were summed for each site and compared with the loads of the primary collector in a manner analogous to the calculation of sampling and analytical precision; however, loads rather than concentrations were used. The median percentage error calculated from the sum of the event loadings and loadings from the primary bulk collections for the total period is slightly higher than the imprecision associated with collection and analysis. It is possible that the handling of the samples could produce minor perturbations in the composition of each sample and that these effects have been amplified by summing the values of each event. Before taking the absolute value of this error, however, a cursory review of the sign of this error term suggests that the event calculations neither consistently underestimate nor overestimate the loading as compared with 
TABLE 2.-Statistical summary of dissolved chemical concentrations in the bulk precipitation samples

[Concentrations estimated to be below the limit of detection for a constituent (table 1) were set equal to zero]

\begin{tabular}{|c|c|c|c|c|c|c|c|c|c|c|}
\hline \multirow[b]{2}{*}{ Constituent } & \multicolumn{3}{|c|}{ Concentration } & \multirow[b]{2}{*}{ Skewness } & \multicolumn{2}{|c|}{$\begin{array}{c}\text { Number of } \\
\text { observations } \\
\text { (detection limit) }\end{array}$} & \multirow{2}{*}{$\begin{array}{c}\text { Concen- } \\
\text { tration } \\
\text { of } \\
\text { blank }\end{array}$} & \multirow{2}{*}{$\begin{array}{c}\text { Median' } \\
\text { percent error } \\
\text { in split } \\
\text { samples }\end{array}$} & \multirow{2}{*}{$\begin{array}{c}\text { Median' } \\
\text { percent error } \\
\text { in replicate } \\
\text { samples }\end{array}$} & \multirow{2}{*}{$\begin{array}{c}\text { Median }^{2} \\
\text { percent error } \\
\text { in event } \\
\text { samples }\end{array}$} \\
\hline & Median & & ange & & Above & Below & & & & \\
\hline Ammonium as nitrogen $(\mathrm{mg} / \mathrm{L})$ & 0.34 & $<0.01$ & $-\quad 3.7$ & 3.6 & 172 & 7 & $<0.06$ & $3(42)$ & $28(19)$ & $39(11)$ \\
\hline Arsenic $(\mu \mathrm{g} / \mathrm{L})$ & $<.1$ & $<.1$ & -4 & 1.5 & 84 & 95 & $<.1$ & $200(25)$ & $0(8)$ & ---- \\
\hline Barium $(\mu \mathrm{g} / \mathrm{L})$ & 2 & $<2$ & -30 & 4.4 & 97 & 82 & $<2$ & $80(25)$ & $20(8)$ & --- \\
\hline Beryllium $(\mu \mathrm{g} / \mathrm{L})$ & $<.5$ & $<.5$ & -.6 & 7.6 & 3 & 174 & $<.5$ & --- & --- & ---- \\
\hline Cadmium $(\mu \mathrm{g} / \mathrm{L})$ & $<1$ & $<1$ & -191 & 5.9 & 87 & 92 & 1 & $176(27)$ & $200(11)$ & \\
\hline Calcium $(\mathrm{mg} / \mathrm{L})$ & 6 & .05 & -41 & 6.7 & 179 & 0 & $<.02$ & $13(43)$ & $26(20)$ & $65(11)$ \\
\hline Chloride $(\mathrm{mg} / \mathrm{L})$ & .44 & .07 & -3.0 & 2.1 & 179 & 0 & .05 & $24(43)$ & $36(20)$ & $55(11)$ \\
\hline Cobalt $(\mu \mathrm{g} / \mathrm{L})$ & $<3$ & $<3$ & -4 & 3.4 & 13 & 166 & $<3$ & $200(6)$ & $200(8)$ & ---- \\
\hline Copper $(\mu \mathrm{g} / \mathrm{L})$ & $<10$ & $<10$ & -120 & 4.1 & 50 & 129 & $<10$ & $200(17)$ & $200(10)$ & \\
\hline Fluoride $(\mathrm{mg} / \mathrm{L})$ & .07 & .01 & -.64 & 4.3 & 179 & 0 & $<.05$ & $40(43)$ & $46(20)$ & $36(11)$ \\
\hline Hydrogen ion $(\mathrm{mg} / \mathrm{L})$ & .040 & .000 & $0-.125$ & .6 & 178 & & -- & $23(42)$ & $23(20)$ & $36(11)$ \\
\hline Iron $(\mu \mathrm{g} / \mathrm{L})$ & 25 & $<3$ & -128 & 1.4 & 178 & 1 & $<3$ & $19(43)$ & $30(20)$ & $43(11)$ \\
\hline Lead $(\mu \mathrm{g} / \mathrm{L})$ & 5 & $<1$ & -78 & 5.5 & 172 & 7 & 1 & $35(43)$ & $32(20)$ & $22(11)$ \\
\hline Lithium $(\mu \mathrm{g} / \mathrm{L})$ & 12 & $<4$ & -59 & .8 & 153 & 26 & 11 & $67(43)$ & $61(17)$ & ---- \\
\hline Magnesium (mg/L) & .1 & $<.14$ & -3.4 & 4.7 & 110 & 69 & $<.1$ & $67(33)$ & $83(14)$ & ---- \\
\hline Manganese $(\mu \mathrm{g} / \mathrm{L})$ & 7 & $<1$ & -91 & 2.8 & 176 & 3 & $<1$ & $15(43)$ & $28(19)$ & $¥ 3(11)$ \\
\hline Mercury $(\mu \mathrm{g} / \mathrm{L})$ & $<.1$ & $<.1$ & -.3 & 3.0 & 28 & 151 & $<.1$ & $150(6)$ & $200(4)$ & ---- \\
\hline Molybdenum $(\mu \mathrm{g} / \mathrm{L})$ & $<10$ & $<1$ & 10 & -- & 0 & 179 & $<10$ & --- & --- & ---- \\
\hline Nickel $(\mu \mathrm{g} / \mathrm{L})$ & 1 & $<1$ & -34 & 7.0 & 111 & 68 & $<1$ & $171(39)$ & $133(14)$ & ---- \\
\hline Nitrate as nitrogen $(\mathrm{mg} / \mathrm{L})$ & .7 & .1 & -2.5 & 1.4 & 179 & 0 & $<.1$ & $0(43)$ & $25(20)$ & $42(11)$ \\
\hline Potassium (mg/L) & .1 & $<.10$ & -2.8 & 6.2 & 104 & 75 & .1 & $28(29)$ & $200(11)$ & --- \\
\hline Selenium $(\mu \mathrm{g} / \mathrm{L})$ & $<.5$ & & $<.5$ & -- & 0 & 179 & $<.5$ & ---- & ---- & ---- \\
\hline Silica $(\mathrm{mg} / \mathrm{L})$ & .17 & $<.009$ & $9-\quad 2.6$ & 3.5 & 172 & 7 & $<.009$ & $78(43)$ & $102(20)$ & ---- \\
\hline Sodium $(\mathrm{mg} / \mathrm{L})$ & .2 & .2 & -1.6 & 1.6 & 122 & 57 & $<.2$ & $0(29)$ & $28(15)$ & $14(11)$ \\
\hline Specific conductance $\left(\mu \mathrm{mho} / \mathrm{cm} @ 25^{\circ} \mathrm{C}\right)$ & 23 & .3 & -250 & 5.6 & 179 & & -- & $13(43)$ & $32(19)$ & --- \\
\hline Strontium $(\mu \mathrm{g} / \mathrm{L})$ & 3 & $<.5$ & -81 & 6.6 & 178 & 1 & $<.5$ & $23(43)$ & $42(20)$ & $43(11)$ \\
\hline Sulfate $(\mathrm{mg} / \mathrm{L})$ & 2.9 & .23 & -47 & 6.6 & 179 & 0 & $<.1$ & $11(43)$ & $19(20)$ & $22(11)$ \\
\hline Total inorganic carbon $(\mathrm{mg} / \mathrm{L})$ & .4 & .1 & -8.6 & 4.9 & 179 & $\mathbf{0}$ & .1 & $0(43)$ & $0(20)$ & $12(11)$ \\
\hline Vanadium $(\mu \mathrm{g} / \mathrm{L})$ & $<6$ & $<6$ & -7 & 13.3 & 1 & 178 & $<6$ & --- & --- & --- \\
\hline Zinc $(\mu \mathrm{g} / \mathrm{L})$ & 13 & $<3$ & -592 & 7.7 & 144 & 35 & $<3$ & $16(37)$ & $85(18)$ & ---- \\
\hline
\end{tabular}

${ }^{1}$ Number in parentheses is the number of paired samples for which the percent error was determined.

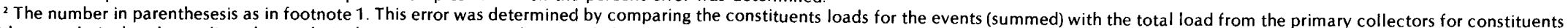

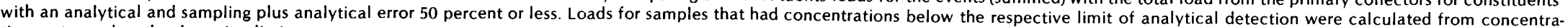
tions set equal to the detection limit. 


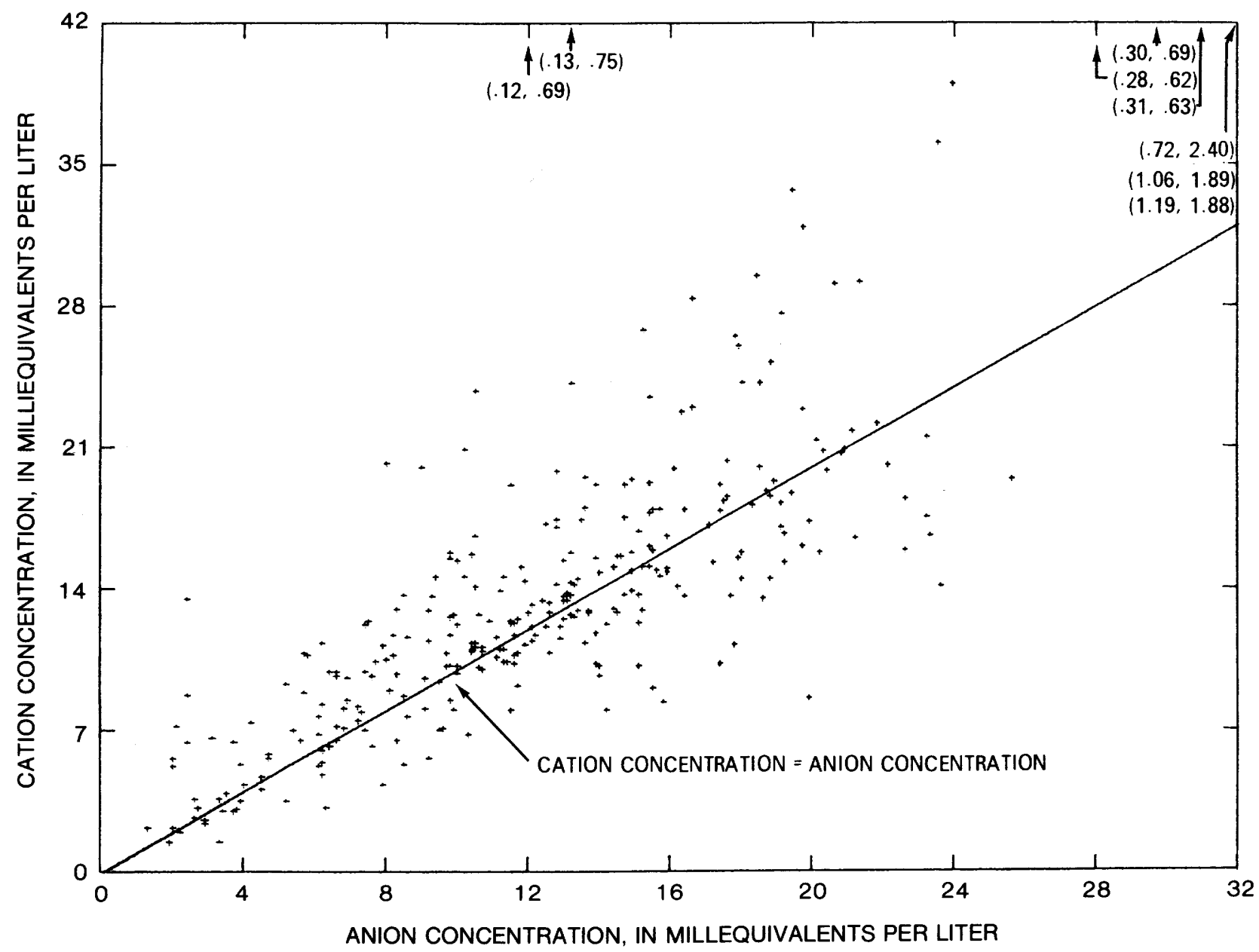

Figure 3. - Cation vs. anion equivalents of all bulk-precipitation samples.

the total bulk collection. Therefore, the changes that may have developed in either the primary sample while it was in the field or the event samples between collection and analysis were minor and apparently random.

As a further check on the precision of the analytical data, a comparison of the total milliequivalents of cations and anions was made. Calcium, magnesium, potassium, sodium, ammonium, and hydrogen ions were included in the cation sum. The anion sum included chloride, sulfate, and nitrate (see fig. 3; table 5 following "References Cited"). As indicated by the graph of cations against anions in figure 3 , some samples appear to contain an excess of cations. Although carbonate bicarbonate alkalinity was not determined, the few samples having very high cation excesses also had high $\mathrm{pH}$ and contained relatively large amounts of calcium and total inorganic carbon. The contribution of carbonate bicarbonate to the anion sum of these samples may be significant, but, in general, the lower $\mathrm{pH}$ of most samples suggests little carbonate bicarbonate contribution.

The discrepancy observed here is not unique; results from other studies indicate the same anion deficiency (McColl, 1980; Natural Resources Ecology Laboratory, 1978-81). A cursory review of the data from the National Atmospheric Deposition Program (National Resources Ecology Laboratory, 1978-81) indicates a slight anion excess in the Eastern United States trending to a large cation excess in the Midwest. Acidification of the samples for determining cation concentrations could release additional cations from particulates not removed by filtration. Although discrepancies were noted in various samples for the cation-anion balance, no determinations were deleted. The analytical data presented in table 5 (following "References Cited") and interpreted herein are complete. 


\section{Constituent Loads}

Data on concentration of dissolved constituents provide a means of discerning and comparing their spatial distributions. However, the slight differences in length of the collection period from site to site, combined with the unequal distribution of precipitation over the region during collection, suggest a need for normalization of data to enable valid comparisons among the individual sites. Therefore, average daily constituent loadings, expressed as mass daily deposition per unit area (microgram per square meter or milligram per square meter), were computed for each sample. The loads were computed by multiplying the concentration by the precipitation quantity (from National Weather Service data) and dividing the result by both the number of sampling days and the area of the collector opening.
The distributions of both concentrations and loads are generally postively skewed, which means that the distributions are asymmetrical, with most observations clustered at low values. To offset this effect, median concentrations were chosen to represent the data populations. Further data analysis that would relate these concentrations from bulk precipitation to geochemical abundance in atmospheric deposition should employ data transformation such as the lognormal distributions of Krige (1960) and Sichel (1952). These methods should take into account the loss of data through censoring or truncation, as would be appropriate for constituent concentrations that were below detection limits (Cohen, 1959).

Because precipitation quantity was a factor in calculating daily constituent loadings, the reported quantity was compared with the collected

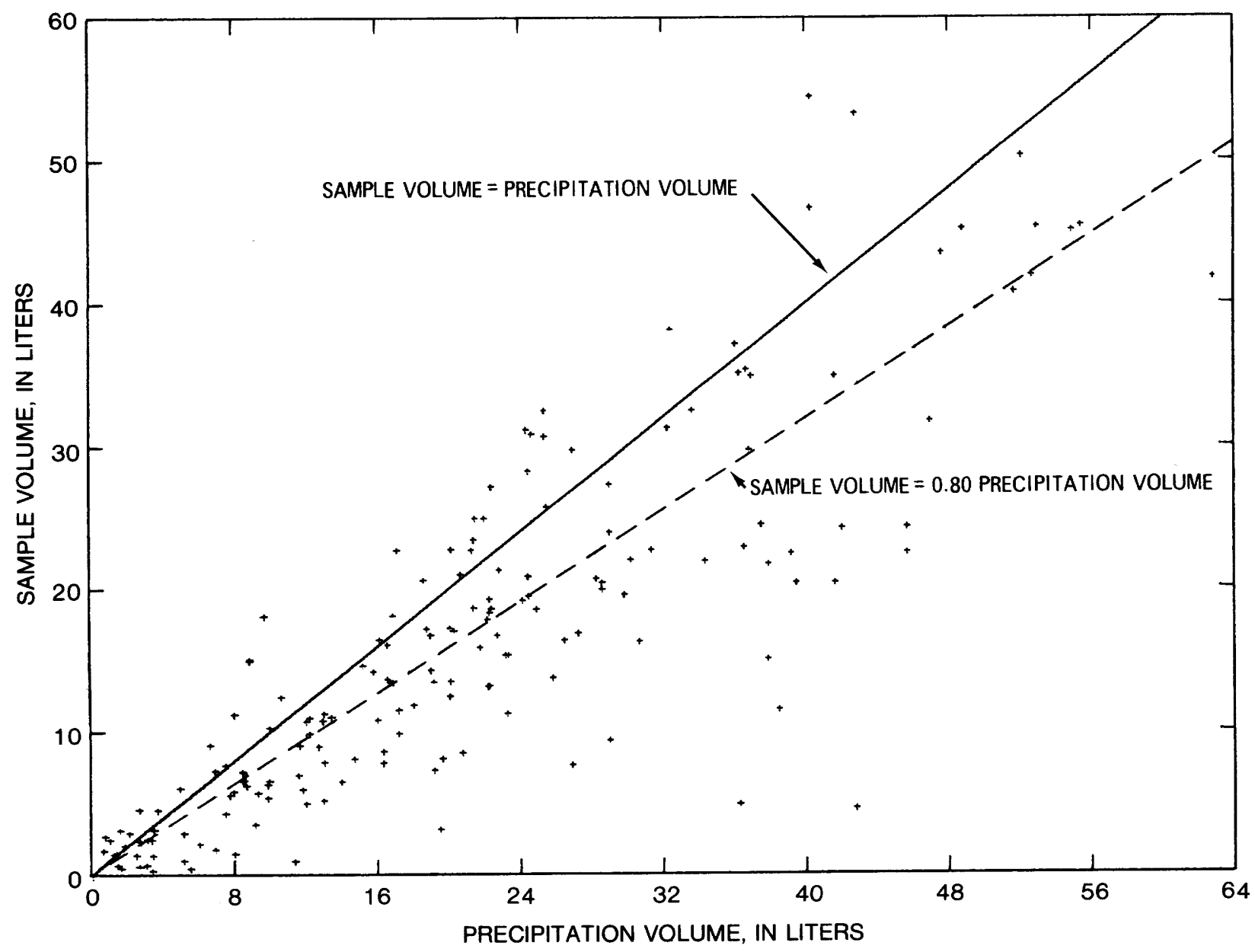

FICURE 4. - Precipitation quantity recorded at the National Weather Service gages vs. quantity actually collected. 
amounts. A graph of reported quantity against collected quantity is shown in figure 4; the relation was calculated from a linear least-squares technique wherein the collected value was the independent variable. Results yield a slope of 0.8 (a slope of 1 would suggest that the amount of water estimated was equivalent to the amount collected), which indicates either that the collectors did not collect the precipitation as efficiently as the rain gages or that they lost some of their collected water through sublimation, evaporation, and (or) leakage.

Although some water loss was probably due to evaporation or sublimation, many of the sample bags leaked. Also, some of the incoming precipitation, particularly snow, may have been lost through wind turbulence (Galloway and Likens, 1978). Although the size of the opening and the depth of the collector suggest that the efficiency of snow collection was similar to that of the weighing-bucket rain gages at the National Weather Service sites, the opening may, in fact, have been smaller than assumed. To calculate precipitation volume from the National Weather Service data, a collector diameter of $45.7 \mathrm{~cm}$ (that of the fiber tube) was used. However, because a plastic bag was wrapped over the edge of the collector and taped to the inside and two bags were suspended within the container and wrapped over the outside, the effective diameter was slightly less than that used in the calculation. A $1.25-\mathrm{cm}$ reduction in diameter would reduce by about 5 percent the calculated quantity intercepted, and a $2.5-\mathrm{cm}$ reduction would diminish the quantity by 10 percent. Because the amount of water lost from the collectors by evaporation or sublimation is not known, neither the constituent concentrations nor the loads have been adjusted for this factor. Where evaporative losses occurred, the constituent loads are slightly overestimated.

\section{RESULTS AND DISCUSSION}

\section{METEOROLOGIC CONDITIONS}

Meteorologic conditions during the study were generally atypical. Low-level air from the Atlantic Ocean or the Gulf of Mexico provided the dominant source of moisture, particularly in February. Although this pattern is normal, the occurrence, intensity, and duration of storms were unusual. December 1980 in the Northeast was colder and dryer than normal, and January 1981 was much colder and drier than normal. In contrast, February was much warmer and wetter than normal.
(See temperature and precipitation maps for these months, fig. 5.)

As a consequence, the requirement that snow cover prevail at least 60 percent of the collection time was not met at most sites. Some precipitation fell as rain, particularly in the southern part of the area, and, during February, many of the samples melted in the collector. Also, only five snow cores - one-quarter of the number expected-could be obtained.

To determine the sources of trace constituents in samples after each storm would require a detailed meteorologic analysis beyond the scope of this study. However, the general circulation pattern of air over the Northern Hemisphere and the movement of low-pressure systems that cause precipitation are depicted in maps of the mean monthly 700-mb pressure surface for December 1980 through February 1981 in figure 6 . The synoptic scale winds characteristic of the general circulation of the atmosphere move approximately parallel with the height contours of the $700-\mathrm{mb}$ pressure surface, which is from the northwest and west in December and January with a more southerly component in February. These winds result from the combination of the Coriolis and pressure-gradient forces. The low-level air from the south and east, which was the dominant source of moisture during the study, generally followed the west-to-east circulation pattern but had a more southerly component. Mean monthly velocity and direction of surface winds in each State indicate the same general west-to-east transport of air as synoptic scale winds (fig. 7). A more detailed discussion of weather and air circulation is given in Taubensee (1981), Wagner (1981), and Dickson, (1981).

\section{SPATIAL Distribution OF CONSTITUENT DEPOSITION}

Locations of the major urban centers of the area studied are shown in figure 1 ; the distribution of precipitation is shown in figure 8 . Of the 29 constituents analyzed including hydrogen ion, 13 had an analytical and sampling plus analytical precision of 50 percent or less. The areal distribution of concentrations and loads of 12 of these constituents (sodium, chloride, calcium, flucride, sulfate, hydrogen ion, nitrate, lead, iron, ammonium, strontium, and manganese) are summarized in figures 9 through 20 . Because the concentrations are not normalized to account for the variation in length of collection period and 

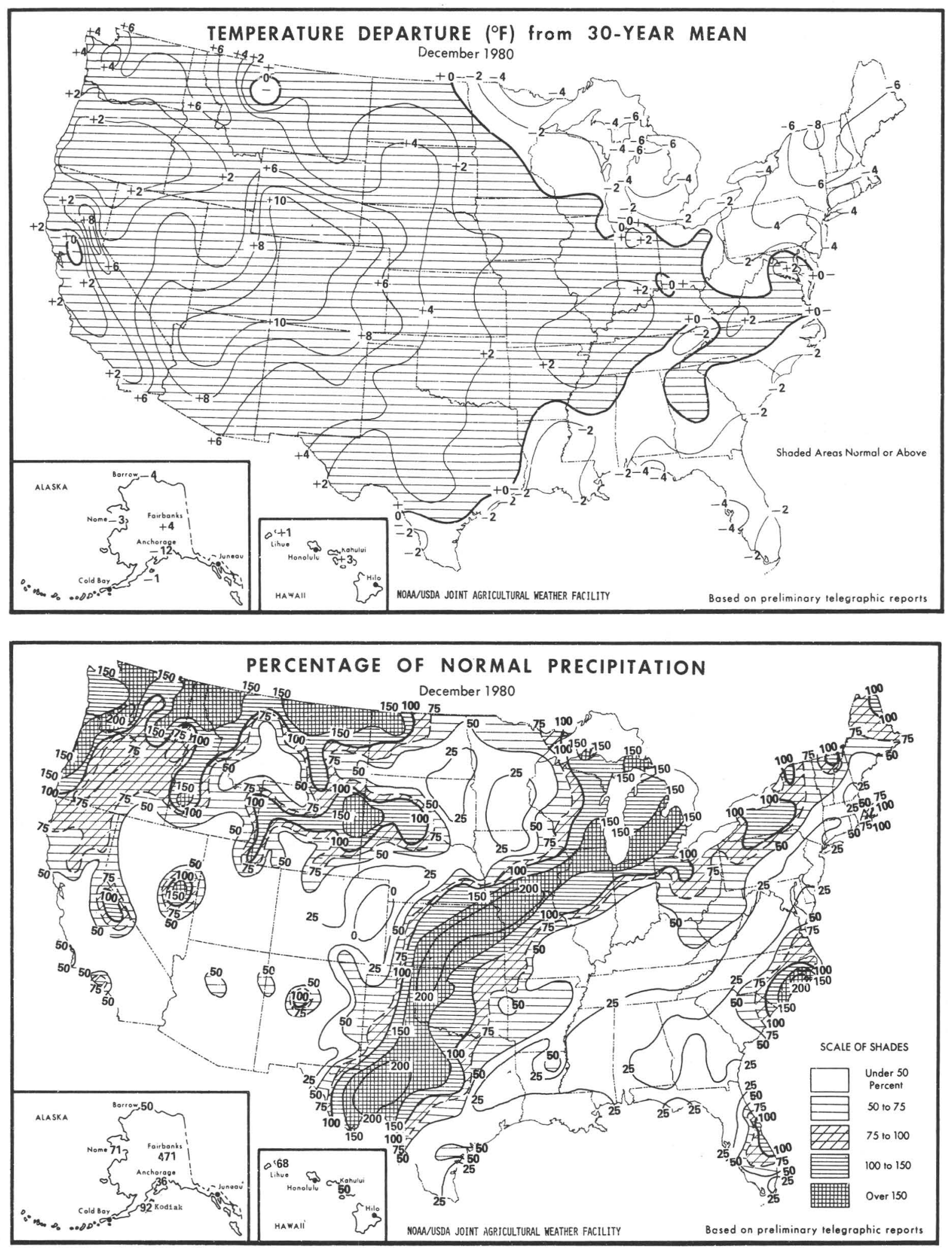

A, December 1980. 

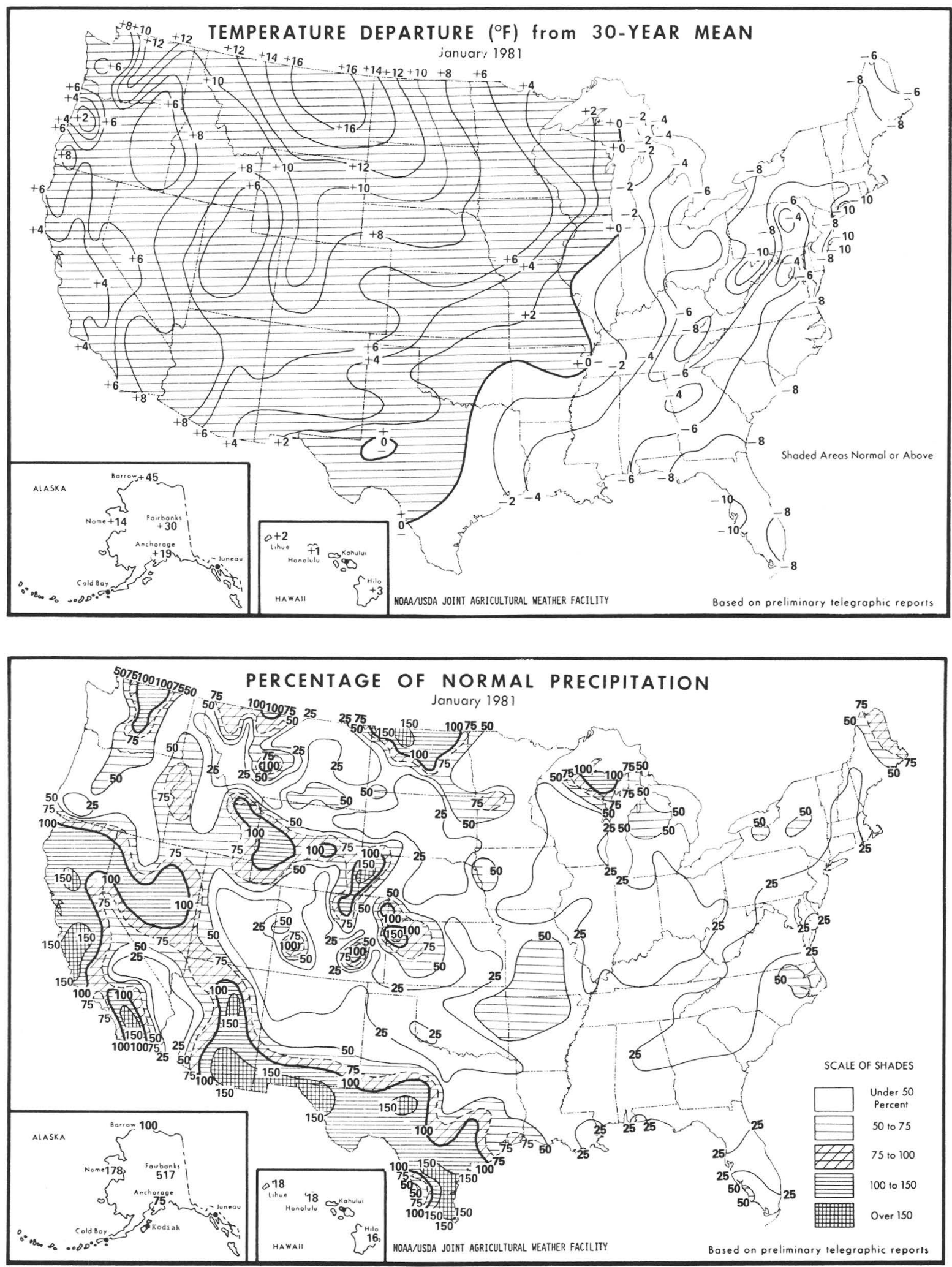

$B$, January 1981 . 

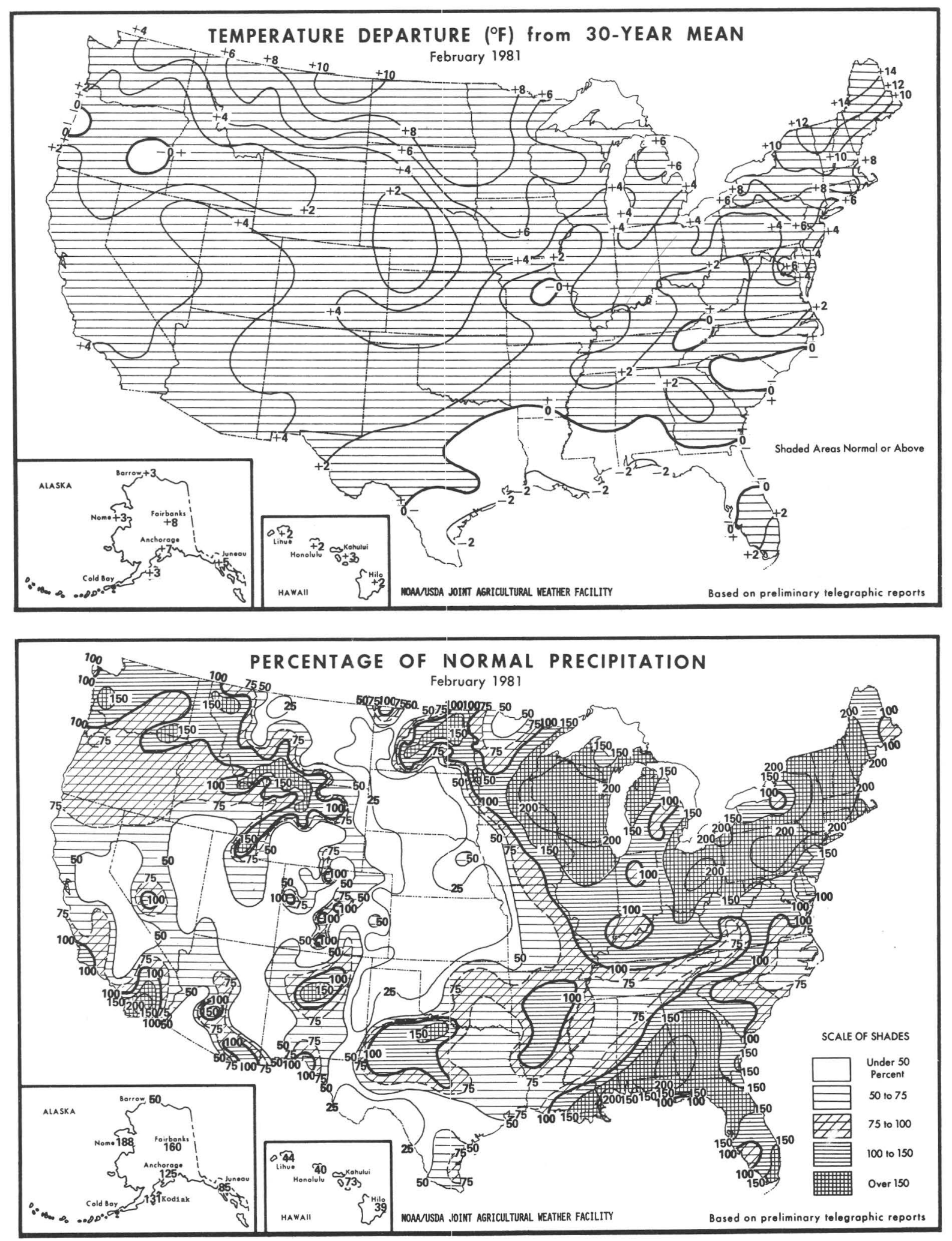

C, February 1981 

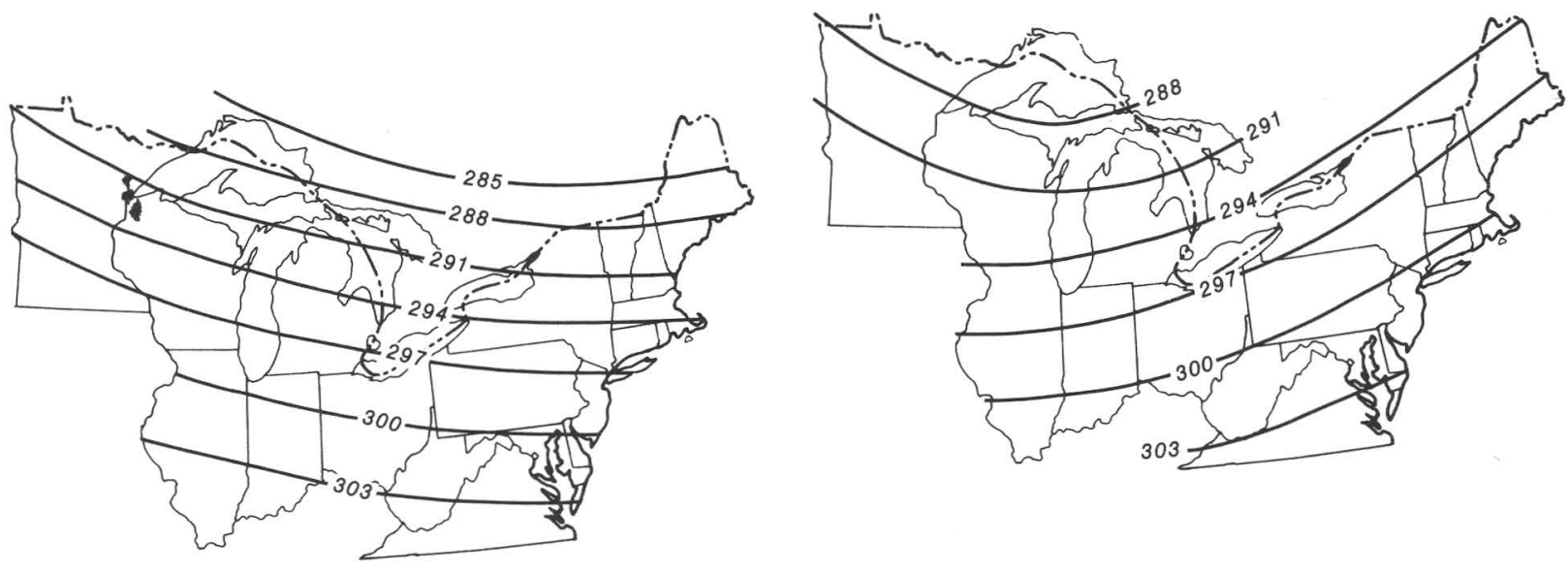

C, February 1981 (from Dickson, 1981).

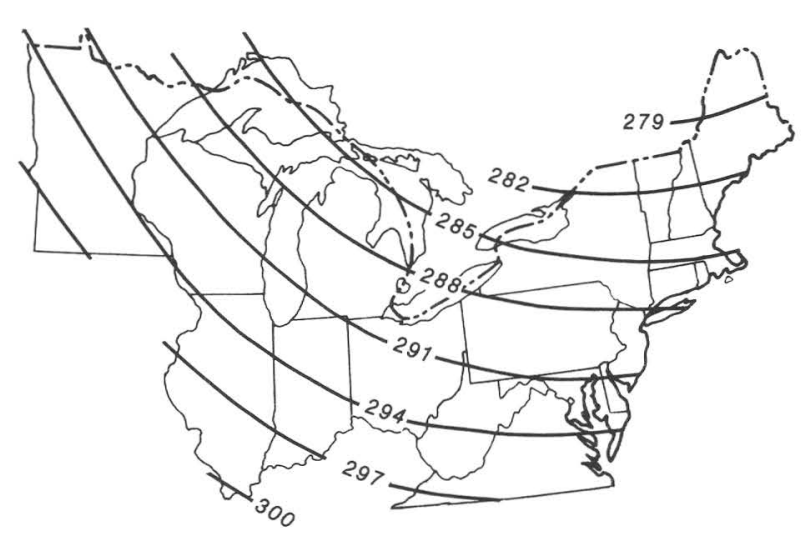

B, January 1981 (from Taubensee, 1981).

precipitation quantity, the following discussion refers mainly to average daily loadings (microgram per square meter or milligram per square meter), which are easier to interpret than concentration. Despite the limitations associated with the collection procedures and the minor analytical uncertainties, clear geographic patterns of concentrations and loads are evident in figures 9 through 20.

The maps reveal both regional and local patterns. By ignoring the local deviations, one can discern regional patterns. Although it is beyond the scope of this report to discuss the local pattern deviations or relate local deviations to plausible source areas, most of the local highs seem to be downwind from urban centers.

\section{Regional Patterns}

Two main distribution patterns of regional bulk precipitation are evident in figures 9 through 18 : a banded pattern and a concentric pattern. The banded one has two subpatterns: an even transition from high to low and a series of alternating highs and lows.

\section{Precipitation, Sodium, and Chloride}

The maps of precipitation distribution (fig. 8) and sodium (fig. 9B) and chloride (fig 10B) loads display a banded pattern. Each shows high deposition along the coastal region that decreases first sharply, then more gradually, to the west. This pattern of chloride deposition and concentration was reported by Jackson (1905) for New York and New England and subsequently by many other investigators. Because both sodium and chloride closely follow this regional pattern, the source is probably sea salt. The general pattern of low loading inland is obscured by local highs near urban centers; these highs may be caused by the cycling of salt used for snow and ice removal.

The band of high precipitation along the east shore of Lake Michigan and extending northward through the Upper Penninsula of Michigan is probably caused by evaporation from Lake Michigan. 


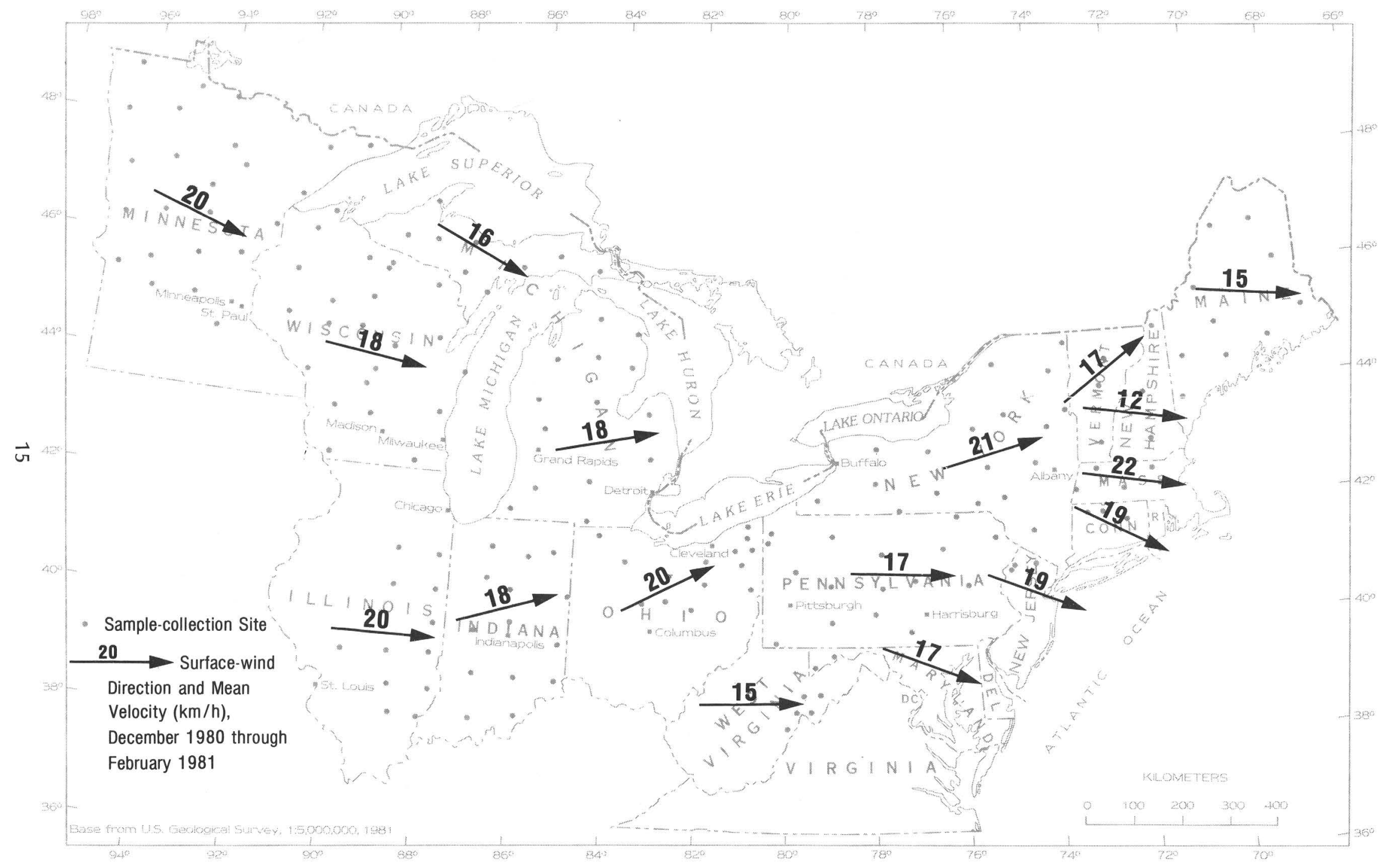

Figure 7. - Average surface-wind patterns over the North-Central and Northeastern United States, December 1980 through February 1981 


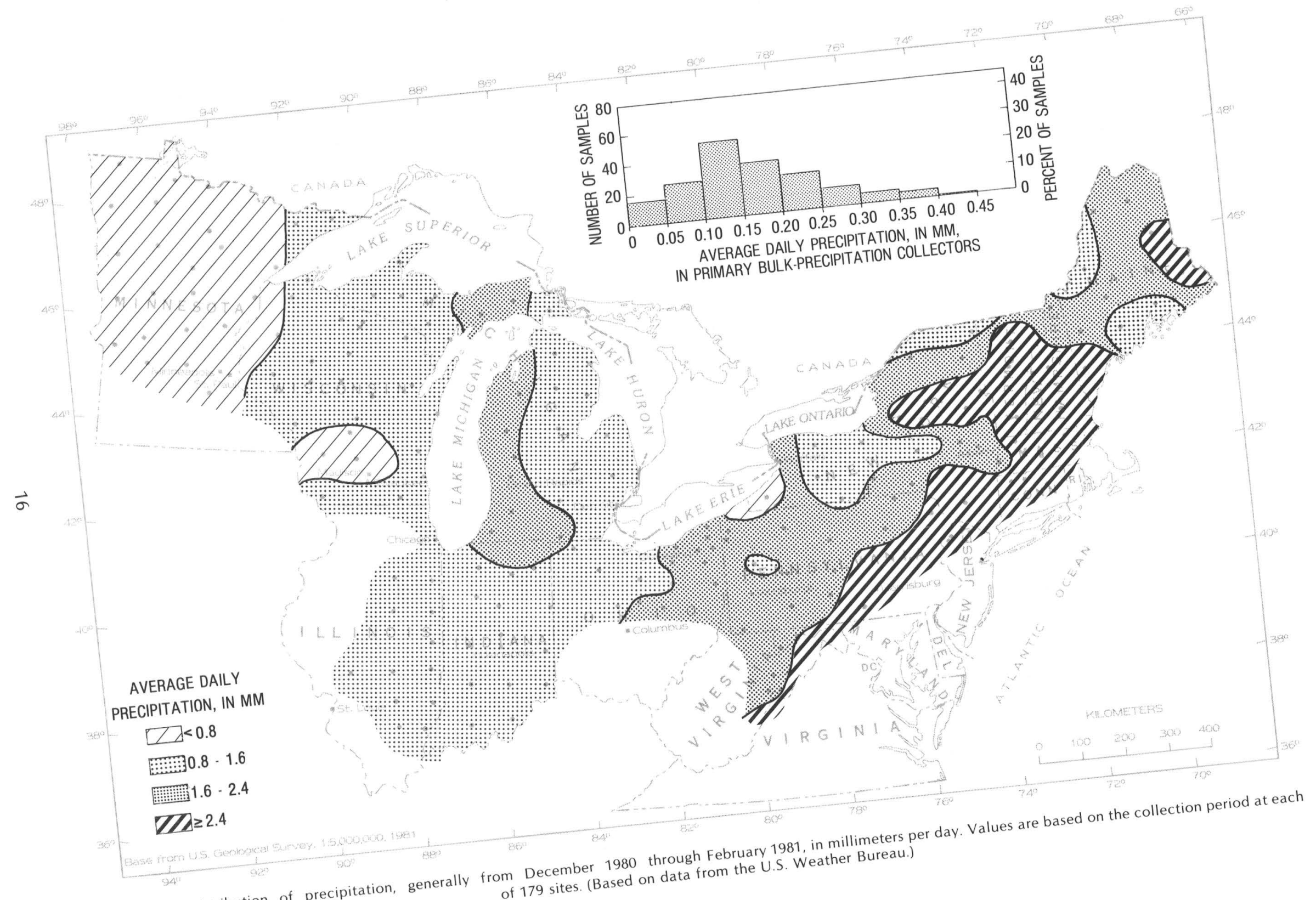

FIGURE 8-Distribution of precipitation, of 179 sites. 
Both the distribution maps and the general meteorologic trends (fig. 7) indicate an eastward transport of both moisture and dissolved constituents in the midwest. This eastward transport is probably obscured in coastal areas by moisture from the ocean.

\section{Calcium}

The distribution of calcium deposition (fig. 11) shows an area of high daily loads ( $\left.\geqslant 2.0 \mathrm{mg} / \mathrm{m}^{2}\right)$ that extends from western Minnesota through IIlinois and southern Indiana. The gradient to lower loading in northeastern Minnesota is much steeper than the one trailing out to the east. The low to the east $\left(<0.5 \mathrm{mg} / \mathrm{m}^{2}\right)$ is similar to that of northeastern Minnesota but begins along the New York-New England border, considerably farther from the regional high than that of Minnesota.

Samples from areas of the highest calcium loading also have the highest concentration of total inorganic carbon and the highest $\mathrm{pH}$ (fig. $14 A$ ), which suggests a chemical control on the solution by carbonate mineral equilibria; soils are possible sources of carbonate minerals in these areas of high loading.

\section{Fluoride}

Fluoride distribution displays a regional series of bands (fig. 12). A region of medium to high daily loads $\left(0.1-0.3 \mathrm{mg} / \mathrm{m}^{2}\right)$ with a north-south trend is indicated in New England. A low is depicted in Maine, and another extends from north-central New York through northeastern Pennsylvania and northern New Jersey. The next band of highs begins just east of the Twin Cities in Minnesota and runs southeast through southern Michigan, eastern Ohio, and southwestern Pennsylvania. The highest loads of this system ( $\left.\geqslant 0.3 \mathrm{mg} / \mathrm{m}^{2}\right)$ form peaks immediately east (downwind) of several urban centers such as Madison, Minneapolis-St. Paul, Grand Rapids, Cleveland, and Pittsburgh. The association of high loads with urban areas suggests local sources. Atmospheric mixing and transport away from the sources could produce a wider distribution of high loading, similar to the regional pattern. Urban sources of fluoride include chemical plants, the electronics industry, and the aluminum and steel industries. (See "Iron".)

\section{Sulfate}

The distribution of sulfate deposition over the Northeastern United States (fig. 13) is depicted as a banded pattern. The highest loads $\left(\geqslant 8.0 \mathrm{mg} / \mathrm{m}^{2}\right)$ occur generally in the southern one-half of the area, whereas lows $\left(<2.0 \mathrm{mg} / \mathrm{m}^{2}\right)$ are indicated only in northern Minnesota and northern Maine.

The sulfate loads reported here are similar to those reported from wet-deposition data over most of the area from November 1979 through March 1980 by Glass and Brydges (in press). The greater detail in U.S. Geological Survey data results from a higher sampling density; figure $13 B$ reveals several areas of high and low loadings that are not evident in the map by Class and Brydges (in press). The local variations in figure $13 B$ may be the result of a combination of sources such as soil particulates, gaseous uptake and subsequent oxidation in solution of sulfur dioxide, and washout of sulfate.

\section{Hydrogen Ion}

Concentric regional patterns of constituent loadings are displayed for hydrogen ion (fig. 14B) and also for nitrate (fig. 15B), lead (fig 16B), ammonium (fig, 17B), and iron (fig. 18B). The main center of the high daily loads $\left(\geqslant 0.15 \mathrm{mg} / \mathrm{m}^{2}\right)$ is in eastern Ohio and western Pennsylvania; another peak is centered over northern New York. The gradient to the west of the main high is less steep than that to the northeast. Minnesota, Wisconsin, Illinois, and a large part of Indiana receive the lowest daily loads $\left(<0.05 \mathrm{mg} / \mathrm{m}^{2}\right)$, with the westernmost part (Minnesota and western $W$ isconsin) receiving the lowest loads $(<0.001$ $\mathrm{mg} / \mathrm{m}^{2}$ ). Although these data are similar to those reported by Class and Brydges (in press), caution should be exercised in concluding that these data reflect the acidity of bulk atmospheric deposition. The conditions under which the samples were taken and processed, the complex chemical equilibria involved, and the difficulties associated with accurate measurement of $\mathrm{pH}$ together cause uncertainity as to the accuracy of individual measurements.

\section{Nitrate and Lead}

These and iron are the only constituents mapped that have distribution patterns (figs. 15, 16) similar to that of hydrogen ion (fig. 14). Each of these constituents has a center of high loading 
FIGURE 9. - Distribution of sodium deposition, December 1980 through February 1981

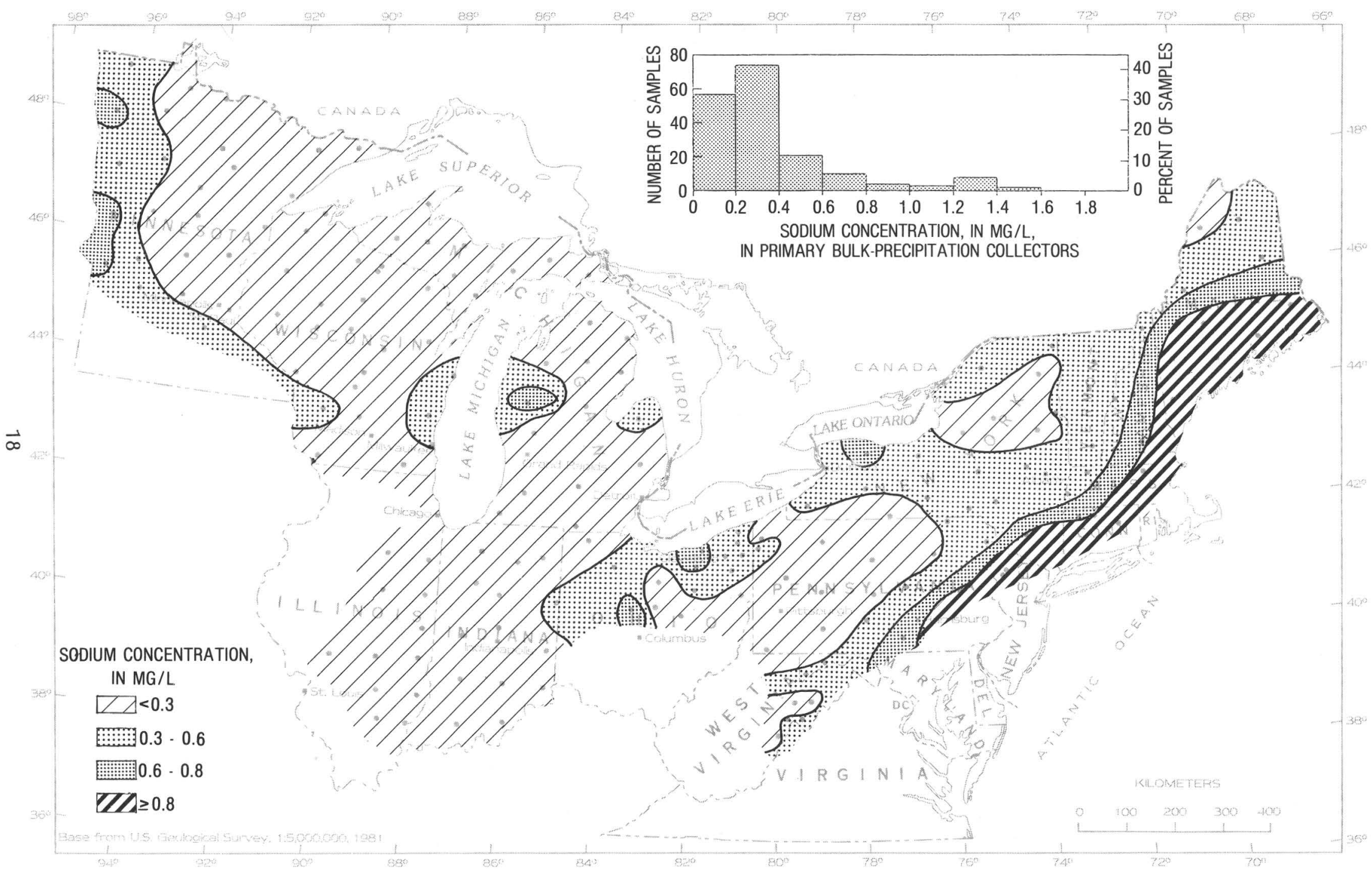

A, Concentration in milligrams per liter. 


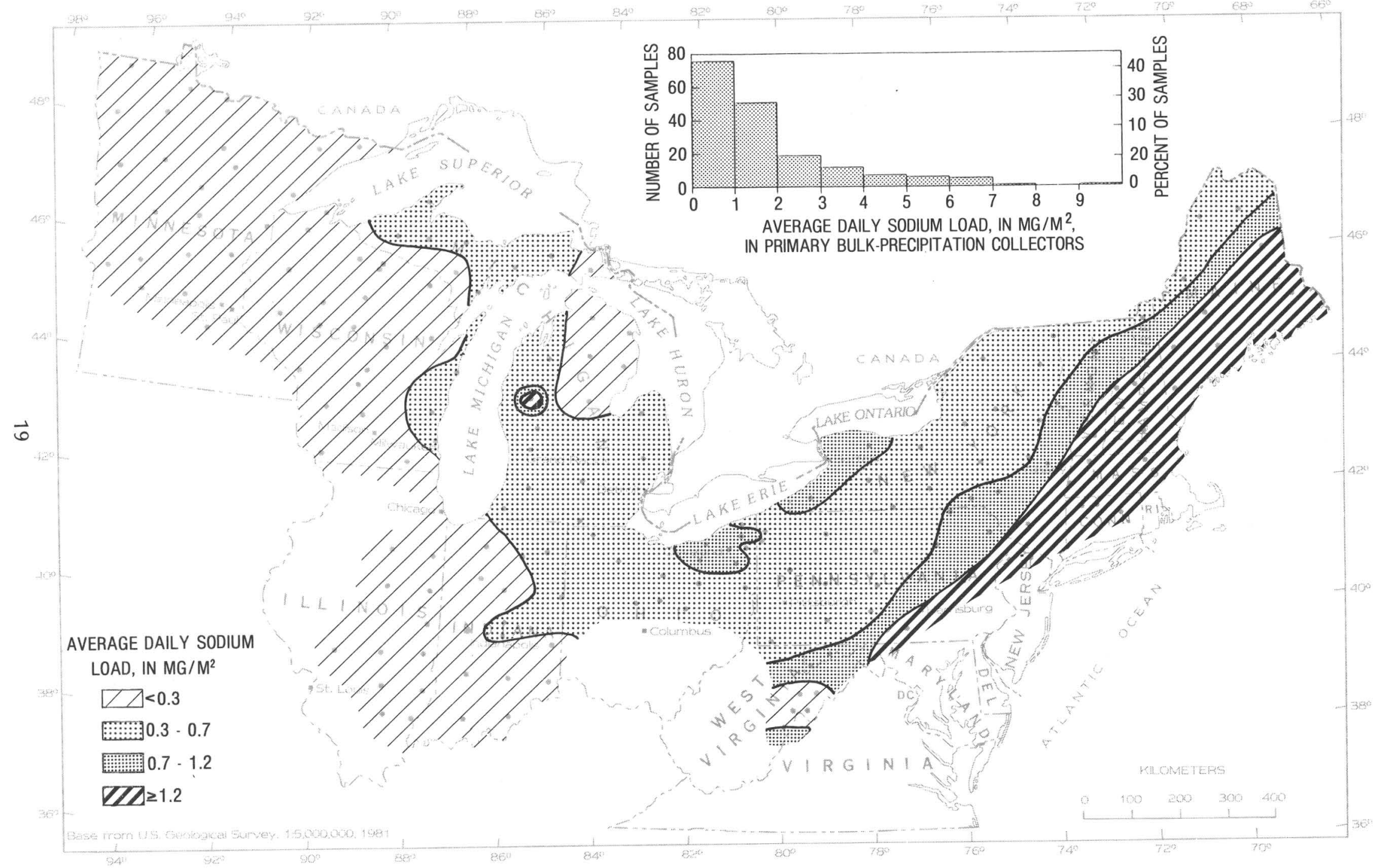

$B$, Daily loads in milligrams per square meter. 


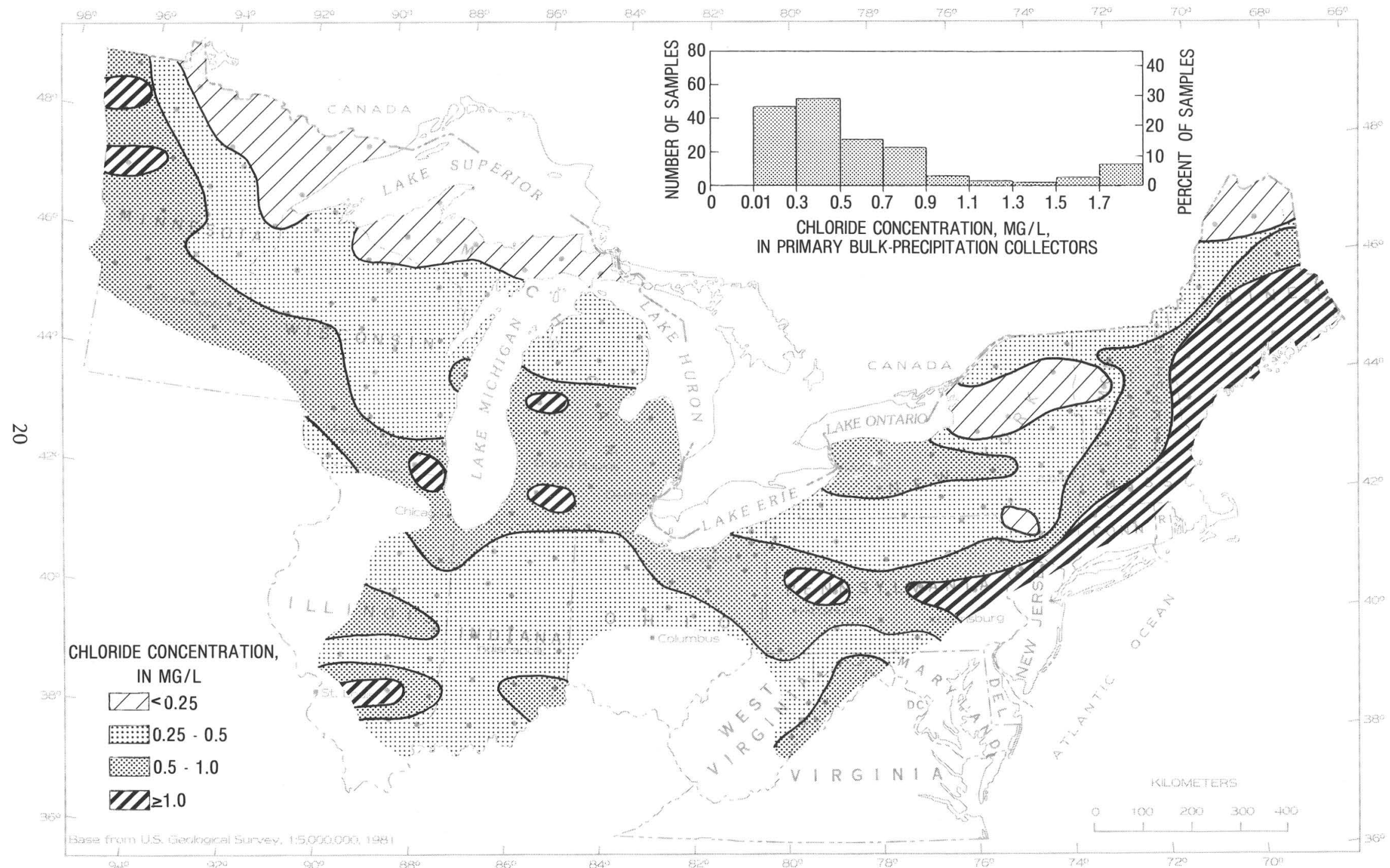




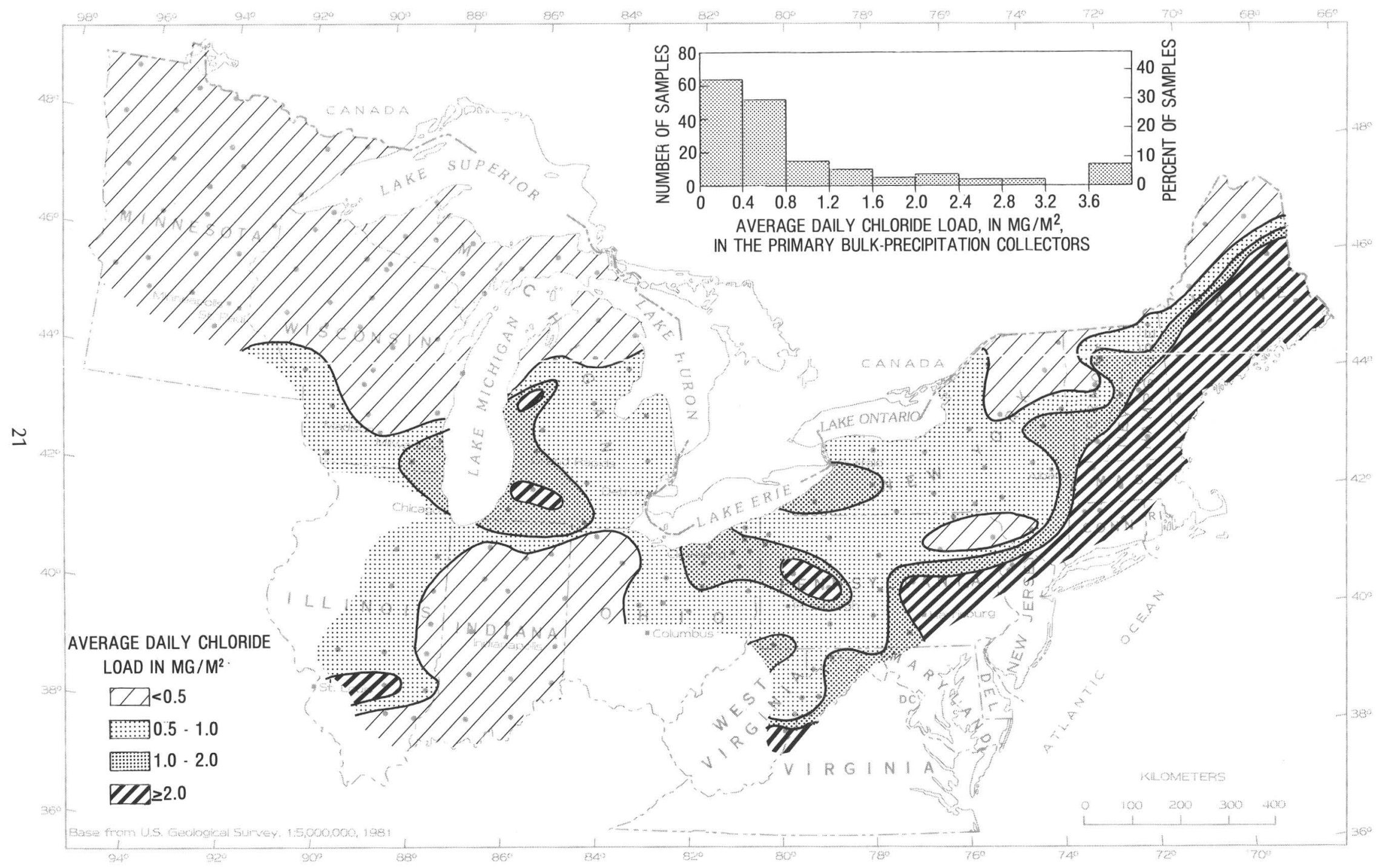

$B$, Daily loads in milligrams per square meter. 
Figure 11. - Distribution of calcium deposition, December 1980 through February 1981.

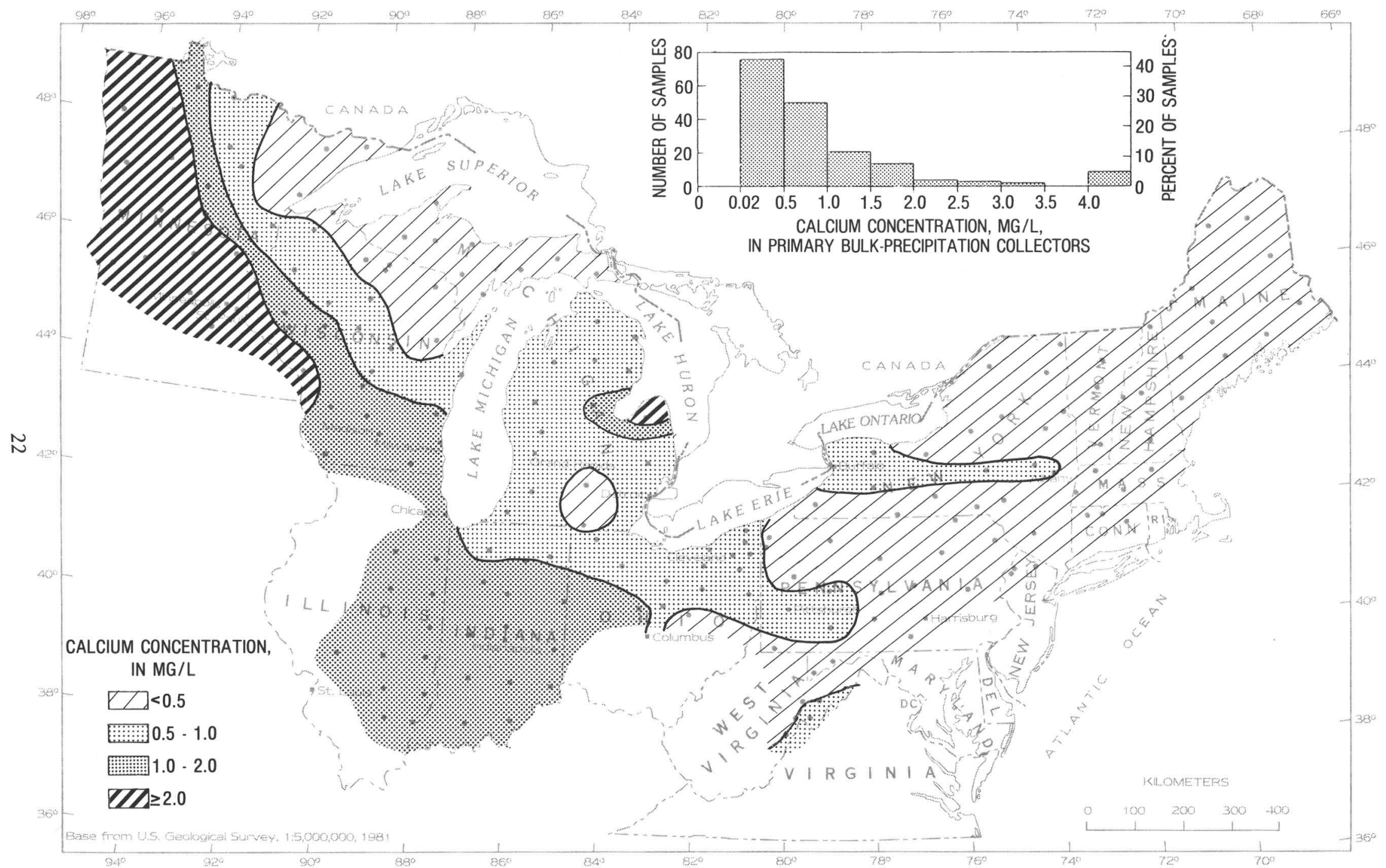




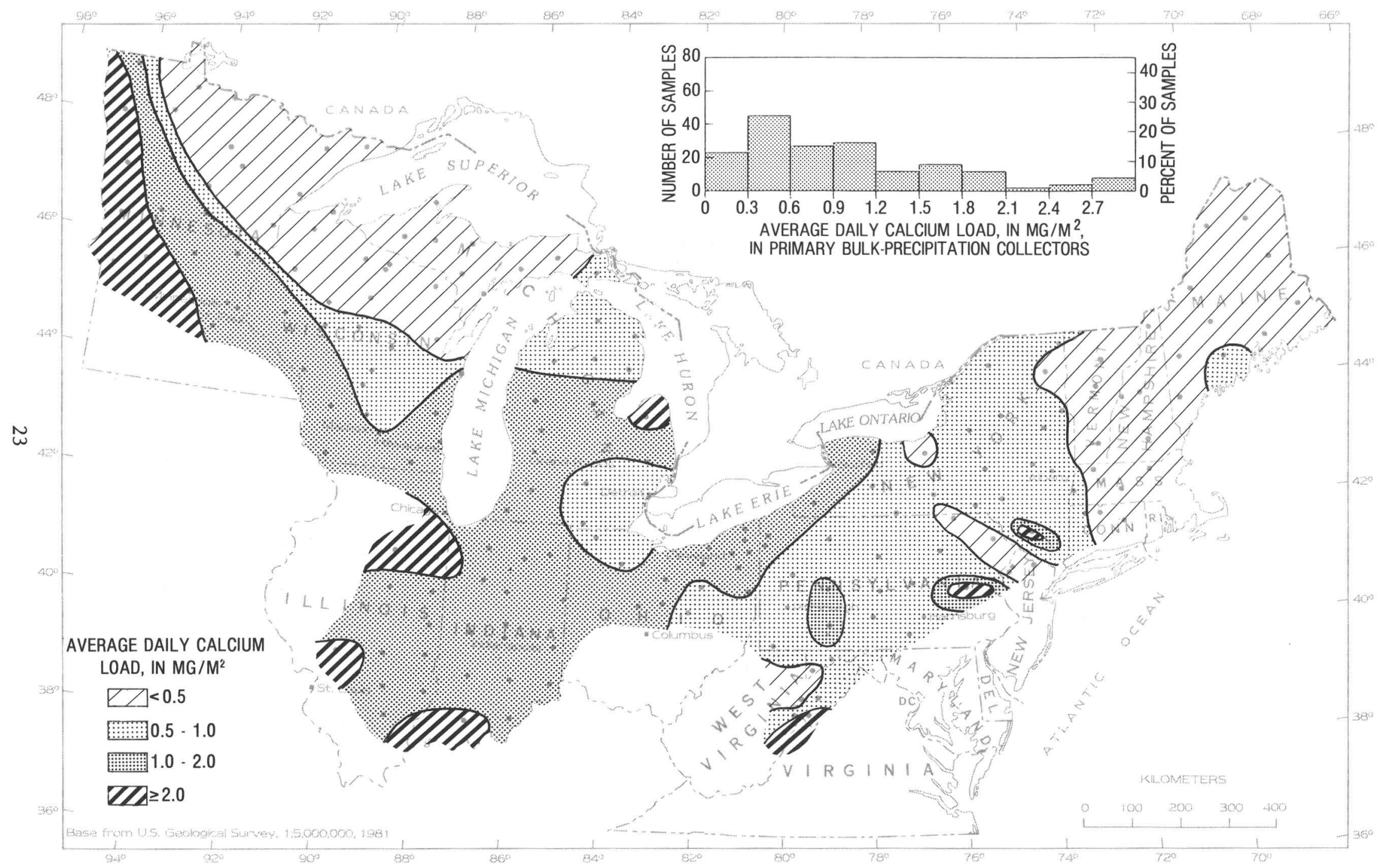

$B$, Daily loads in milligrams per square meter 
FIGURE 12.-Distribution of flouride deposition, December 1980 through February 1981

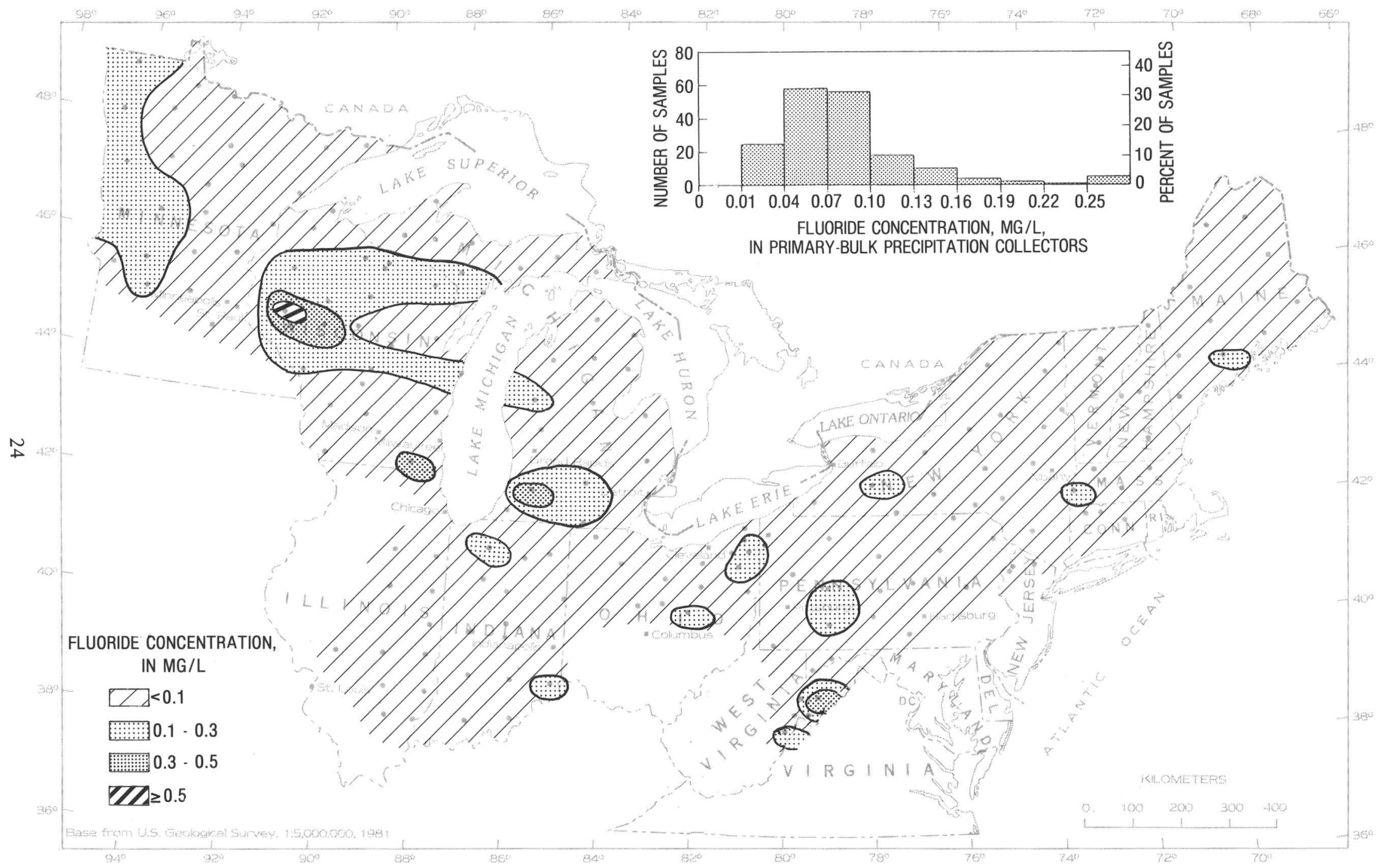

$A$, Concentration in milligrams per liter. 


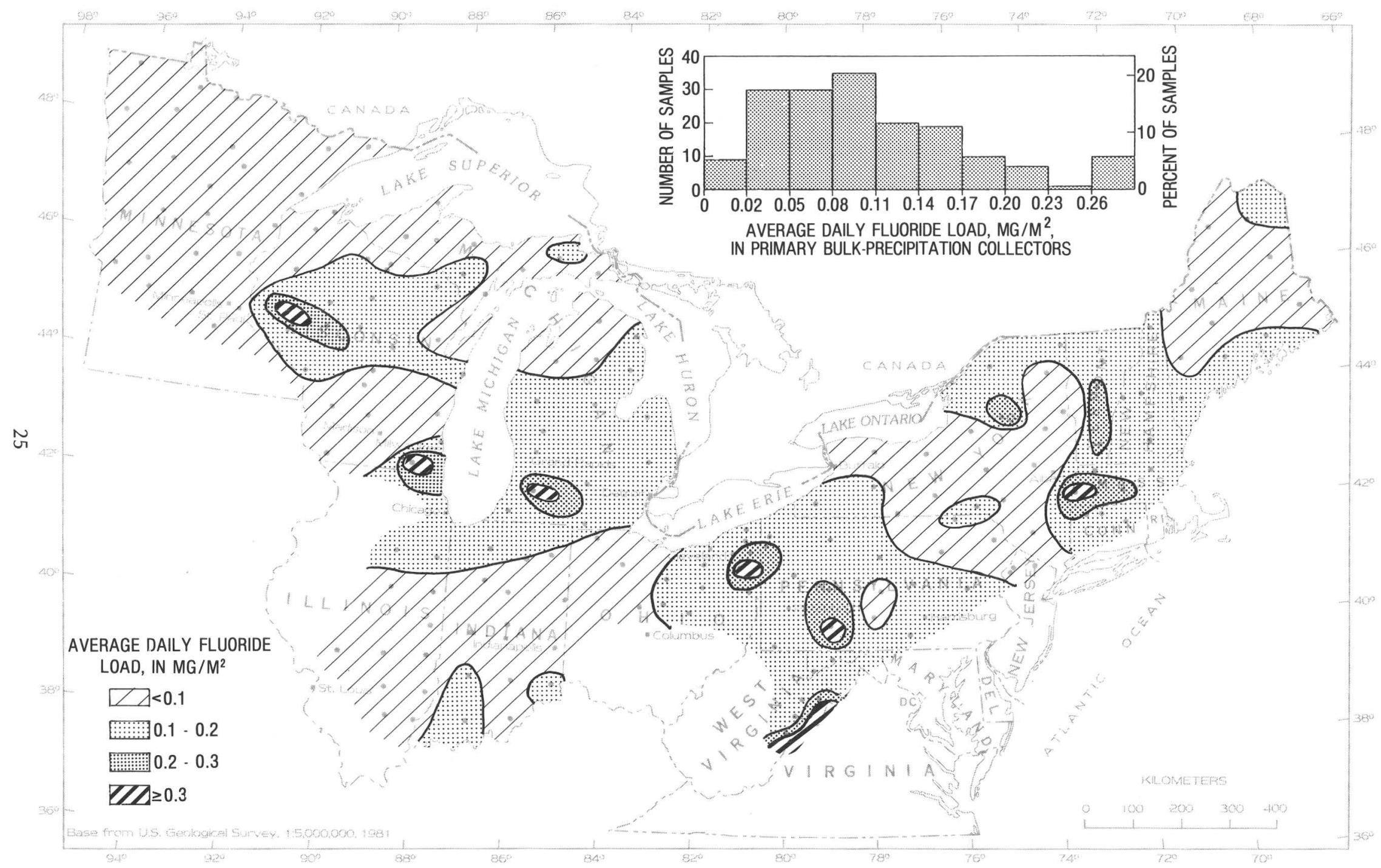

$B$, Daily loads in milligrams per square meter. 


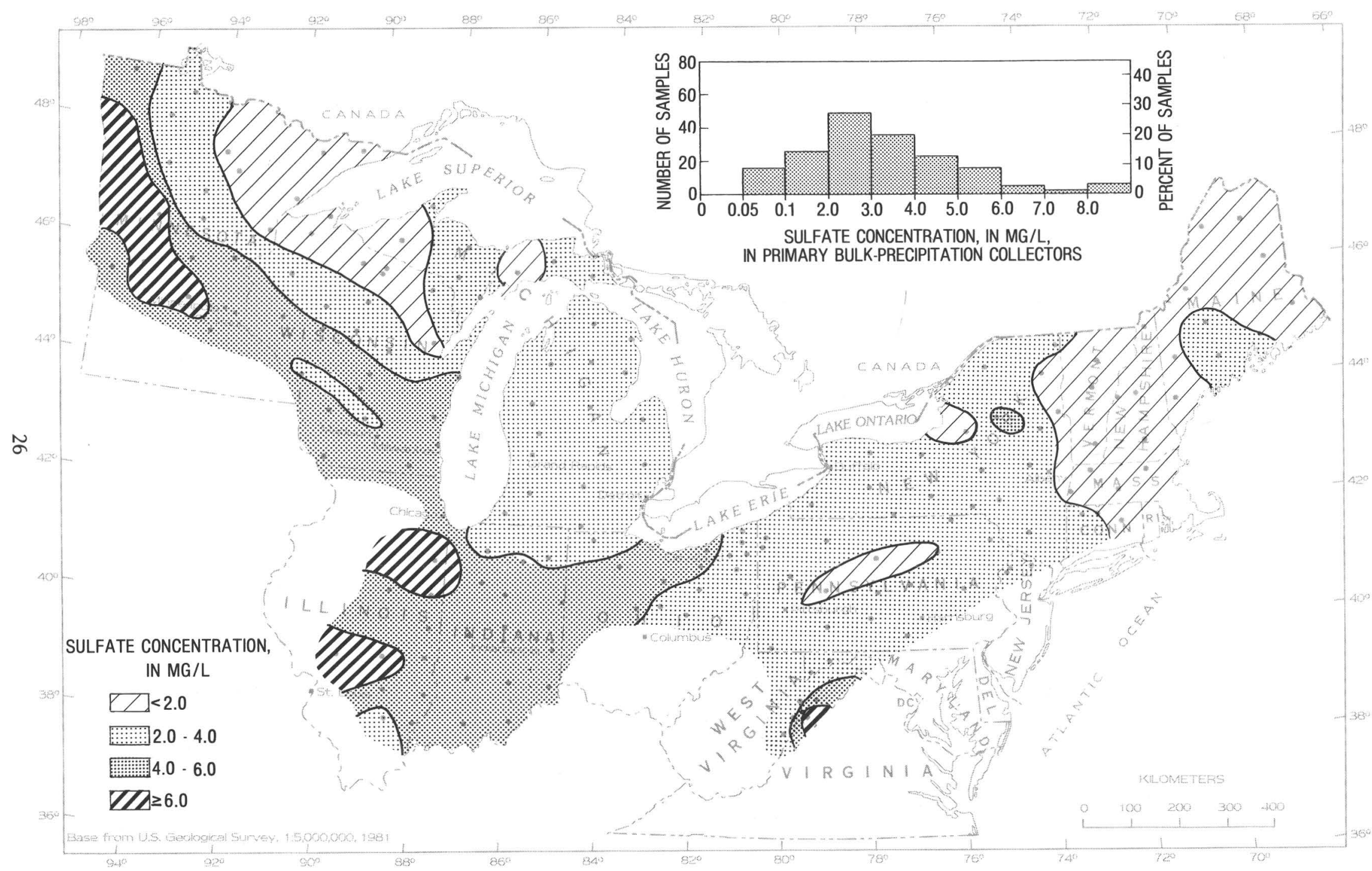




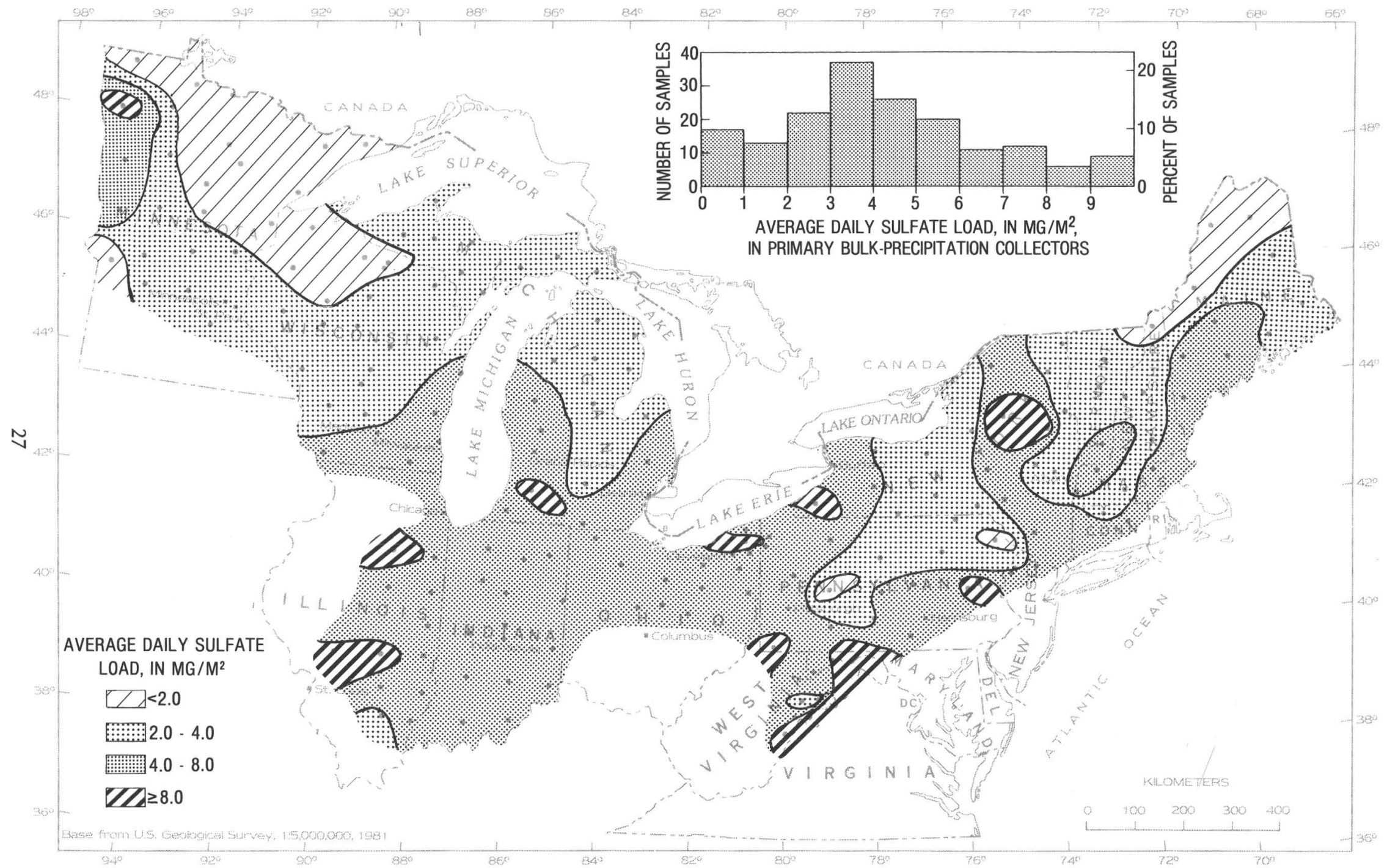

$B$, Daily loads in milligrams per square meter. 


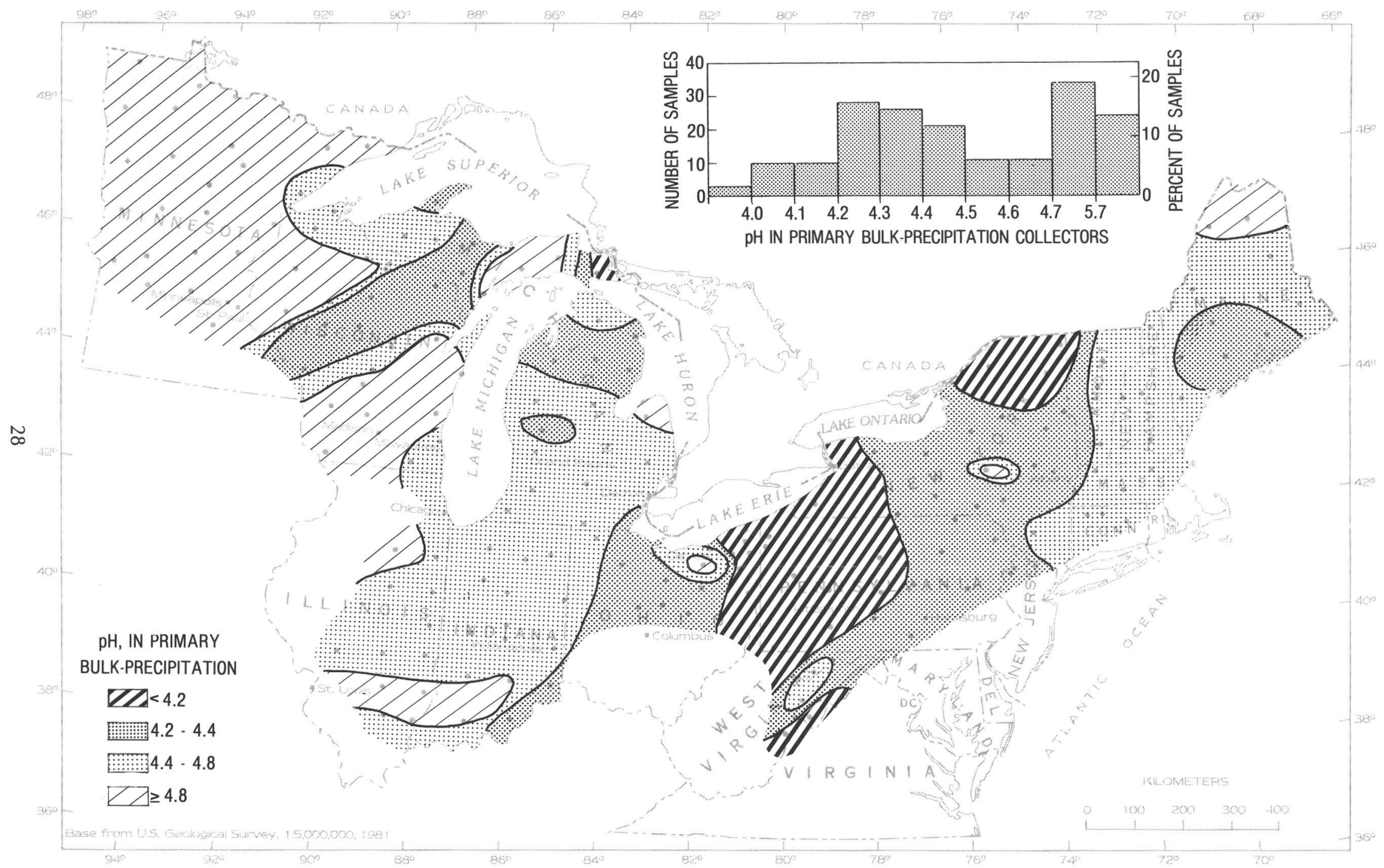




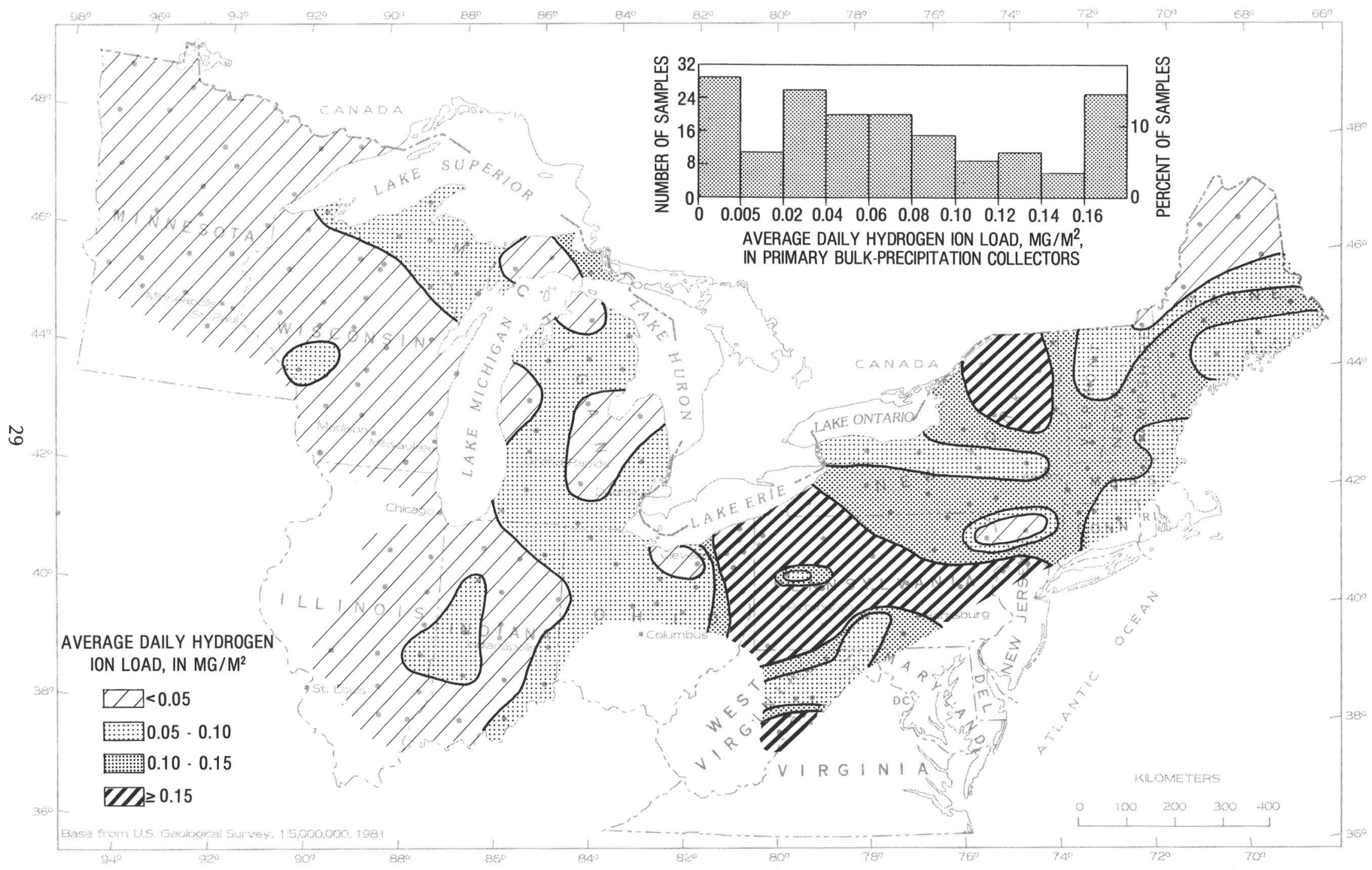

$B$, Daily loads in milligrams per square meter. 


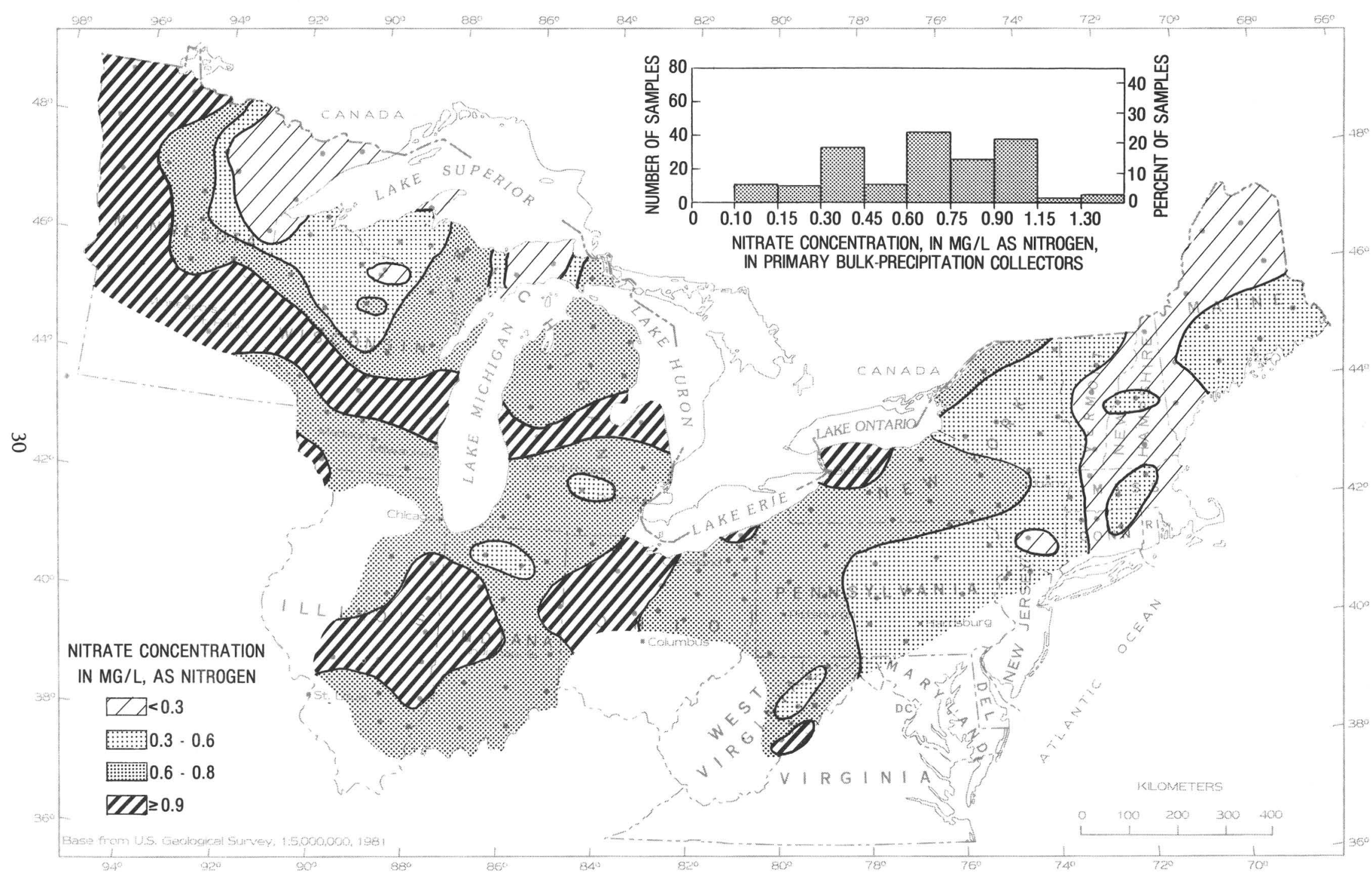

A, Concentration as nitrogen in milligrams per liter. 


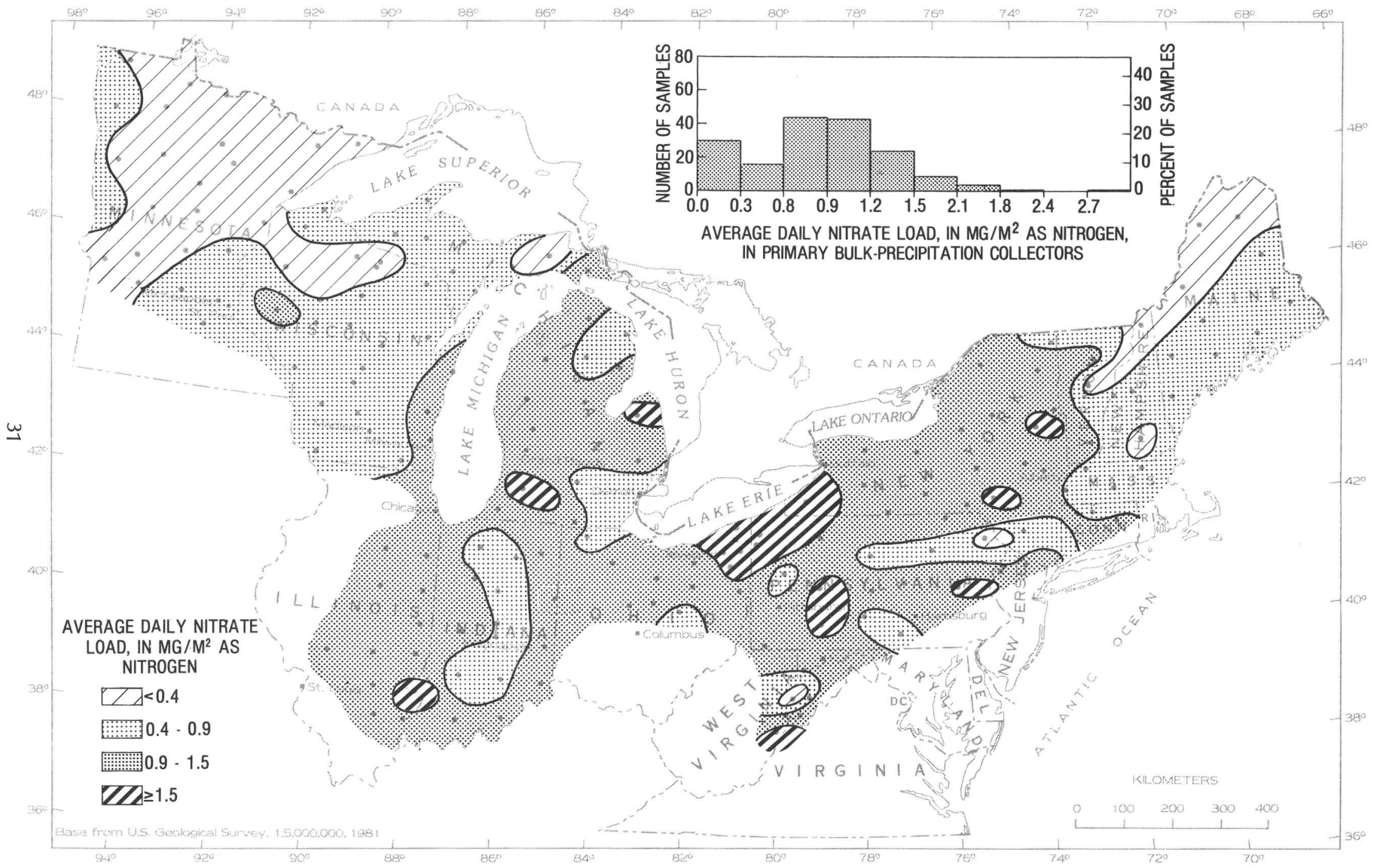

$B$, Daily loads as nitrogen in milligrams per square meter. 


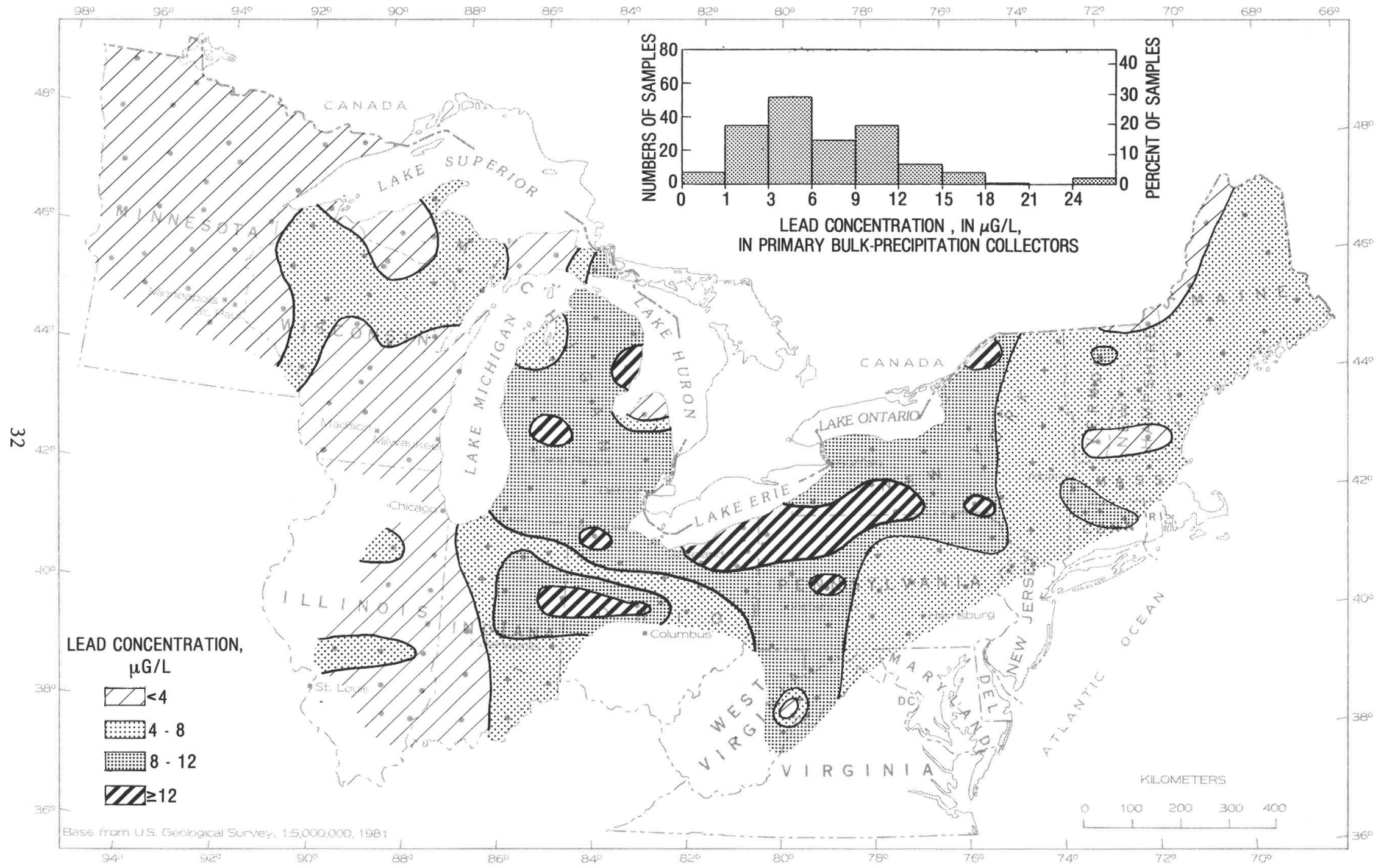




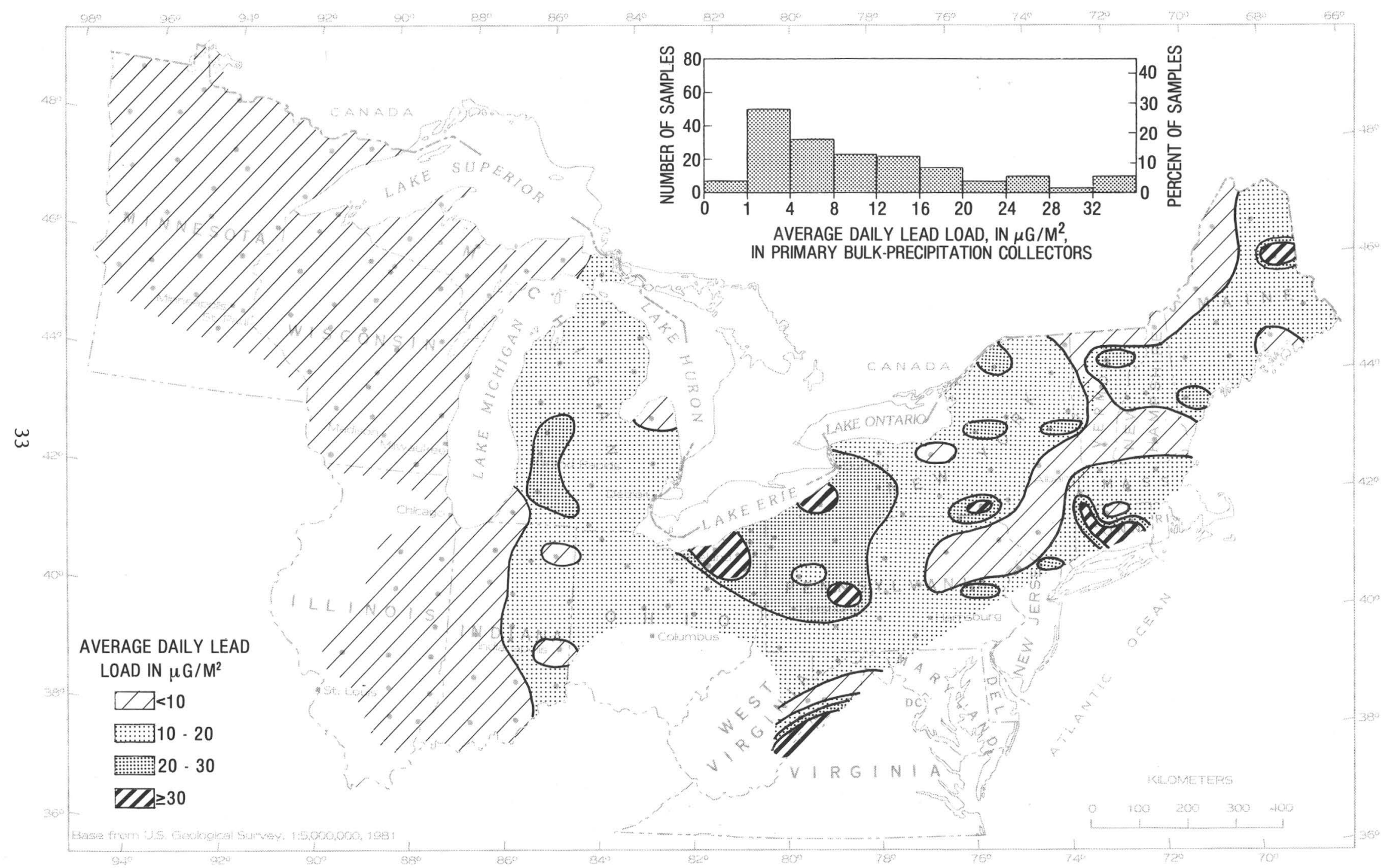

$B$, Daily loads in micrograms per square meter. 
near the main center of high hydrogen ion loads. Patterns of nitrate loads (fig. 15B) are similar to those of hydrogen ion northeast of the high in western Pennsylvania. Although the nitrate loads generally decrease to the west, they do not correlate with hydrogen ion patterns there. Lead distribution (fig. 16) shows the same westward decline as hydrogen ion but has more numerous local highs and lows to the northeast.

Deposition of nitrate is low $\left(<0.4 \mathrm{mg} / \mathrm{m}^{2}\right.$ as nitrogen) in Minnesota northwest of a line extending from the northwest shore of Lake Superior southwest through Minnesota. In addition, values are low in a band parallel to the line in Minnosota but extending from the Detroit area in Michigan to the southwest corner of Indiana. This low is followed by a band of highs centered 200 $\mathrm{km}$ to the northwest; the ridge extends from St. Louis through the Lower Peninsula of Michigan.

The distribution of nitrate concentrations (fig. $15 A$ ) is similar to those reported by Junge (1958) for wetfall samples collected from January to March 1957; Junge did not report the zone of high concentrations in Illinois and Indiana, however. In the areas of high nitrate concentration (fig. 15A) that coincide with those of Junge (1958), concentrations are twice as high as those reported by Junge. Although the similarities between the patterns of hyrdogen ion (fig. 14A), nitrate (fig. 15A), and lead (fig. 16A) may be coincidental, other explanations are possible.

The association between hydrogen ion and nitrate rather than hydrogen ion and sulfate is puzzling. Galloway and Likens (1981) have suggested the increasing importance of nitric acid as a contribution to acid rain in recent years; this may account for the associations observed here.

The apparent correlation between lead and hydrogen ion may reflect the higher dissolution rate and higher solubility of lead in acidic solutions. The distribution of dissolved lead loads (fig. $16 B$ ) correlates with the laboratory $\mathrm{pH}$ of the primary bulk samples (fig. $14 A$ ); the lower $\mathrm{pH}$ of these bulk samples could cause more lead to be leached from intercepted dustfall.

\section{Ammonium}

Ammonium load (fig. 17B) shows the same concentric pattern as hydrogen ion (fig. 14B), nitrate (fig. 15B), and lead (fig. 16B) but with a center in southern Illinois and western Indiana. The gra- dients toward lower loads are steeper to the north and west than to the east. However, the area of high loading ( $\geqslant 0.9 \mathrm{mg} / \mathrm{m}^{2}$ as nitrogen) correlates closely with the nitrate band.

The distribution of ammonium concentration noted by Junge (1958) is also similar to that in figure $17 \mathrm{~A}$ except in the zone of high concentration in Illinois and Indiana, where Junge found low concentrations. The concentrations reported by Junge (1958) are one-third of those found in this study.

The alternating bands of high and low nitrate loads west of the center of high loading warrant discussion because they do not correlate with the observed distribution of lead or hydrogen ion in that area. Possible explanations are use of nitrogen fertilizer for farming or release and subsequent oxidation of ammonia from alkaline soils. Both are exemplified by the distribution of ammonium load (fig. 17B).

\section{Iron}

The distribution of iron loads (fig. 18B) is also concentric, with a center of high load in the same general vicinity as the high hydrogen ion, (fig. $14 B$ ), nitrate (fig. 15B), and lead (fig. 16B) loads. The association of iron with hydrogen ion could be caused by dissolution of iron from soil particulates in more acidic solutions. Also, although fluoride (fig. 12B) shows other areas of high loading, high fluoride loads correlate well with the high iron loads (fig. 18B) in eastern Ohio, western Pennsylvania, and southern Michigan.

Fluoride is a component of the flux used in smelting iron and could be released to the atmosphere with iron during the smelting and handling processes. Processing of primary metals in the Northeastern United States is centered in the same areas as production of fabricated metal products (U.S. Geological Survey, 1970). These areas include the southern one-third of the western shore of Lake Michigan, southeastern part of Michigan, and areas in eastern Ohio and western Pennsylvania. Eastward transport from the western shore of Lake Michigan, southwestward transport from southern Michigan, and deposition adjacent to sources in Ohio and Pennsylvania could produce the pattern depicted for iron and fluoride.

The dominant fluoride mineral used by these industries is fluorspar $\left(\mathrm{CaF}_{2}\right)$. Approximately 50 percent of the total consumption of fluorspar in 
the United States occurs in the Northeast -13 percent in Ohio; 10.5 percent in Pennsylvania; approximately 4 percent in each of Illinois, Indiana, Michigan, and West Virginia; and 10 percent in New Jersey and southern New England (U.S. Bureau of Mines, 1977.) Of the total fluorspar consumption, 44 percent was consumed by the iron and steel industry and 40 percent by the chemical industry (U.S. Bureau of Mines, 1977).

\section{Strontium}

The distribution of strontium loads (fig. 19B) shows no distinct pattern. A region of high values with peaks and depressions extends from southern New England to southeastern Indiana; loads diminish to the north and west of this region. The strontium data are notable because the concentration was determined precisely and shows variations in abundance in rocks, soils, and vegetation. These facts may provide a basis for investigating the types and quantities of materials collected.

\section{Manganese}

The distribution of manganese (fig. 20B) shows a center of high load similar to that of iron (fig. $18 B$ ) in eastern Ohio and western Pennsylvania, but, west of this area, the patterns are dissimilar. In general, the pattern of manganese loading indicates a decrease from the southwestern part of the area to the north and northeast, which correlates with the pattern of sulfate (fig. 13B).

\section{TRACE-METAL LOADS}

The pattern of deposition of selected trace metals in this study compares well with data compiled from many studies for North America by Jeffries and Snyder (1981); the minimum and maximum daily loadings of lead, copper, nickel, zinc, cadmium, and manganese presented herein generally bracket the ranges given in their study (table 3 ). The only constituent having a greater maximum load in this study than in that of Jeffries and Snyder is iron.

A comparison of the median loads in both studies reveals major differences (table 3 ); the median values of most of the trace metals are lower in this study. The filtration of samples before analysis in this study could have caused the values to be lower than those of Jeffries and Snyder (1981); however, median loads of all trace
TABLE 3.-Deposition of lead, copper, nickel, zinc, cadmium, manganese, and iron in bulk precipitation

\begin{tabular}{|c|c|c|c|c|c|}
\hline \multirow[b]{3}{*}{ Element } & \multicolumn{5}{|c|}{$\begin{array}{c}\text { Daily deposition } \\
\text { (microgram per square meter) }\end{array}$} \\
\hline & \multicolumn{3}{|c|}{ North America* } & \multicolumn{2}{|c|}{$\begin{array}{c}\text { North-Central and } \\
\text { Northeastem United Statest }\end{array}$} \\
\hline & \multicolumn{2}{|c|}{ Range } & \multirow{2}{*}{$\frac{\text { Median }}{44}$} & \multirow{2}{*}{$\begin{array}{c}\text { Range } \\
0.2-180\end{array}$} & \multirow{2}{*}{$\frac{\text { Median }}{9}$} \\
\hline Lead__-_-_-_-_- & 12 & 87 & & & \\
\hline Copper & 4 & 22 & 10 & $1.2-230$ & 15 \\
\hline Nickel _._. & $<4$ & 13 & - & $.04-55$ & 2 \\
\hline Zinc & 25 & 266 & 130 & $.5-880$ & 18 \\
\hline Cadmium _...-- & .3 & 2.4 & 1.8 & $.2-370$ & 2 \\
\hline Manganese & 6.6 & 29 & 8.2 & $.2-220$ & 8 \\
\hline Iron & $4.1-$ & 800 & 600 & $1.3-240$ & 34 \\
\hline
\end{tabular}

* Values are for annual average daily loads from Jeffries and Snyder (1981).

t From primary collectors in this study.

metals, except lead and iron, in unfiltered samples from a rural site in south-central Ontario adjacent to the area described in this study are comparable to or slightly lower than those reported here. The median iron load reported here is lower by more than an order of magnitude than that reported by Jeffries and Snyder (1981), and the median load of lead reported here is also about 5 times smaller than that reported by them (table 3). These differences may result partly from the extremely low daily loads observed throughout Minnesota, Wisconsin, and Illinois during the 1981 winter (fig. 14B). Also, the lead load estimates of Jeffries and Snyder may not reflect the temporal decrease in lead associated with the reduced production and consumption of leaded fuels. Troutman and Peters (1982) reported annual daily loads of total lead (unfiltered acidified samples) in three basins in the southwestern Adirondack Mountains of New York for 1978 to 1979 to be $50 \mu \mathrm{g} / \mathrm{m}^{2}$. Siccama and Smith (1978) reported annual daily average load (total) of 87 $\mu \mathrm{g} / \mathrm{m}^{2}$ in 1975 at the Hubbard Brook Experimental Forest of New Hampshire. Both studies indicate a greater rate of deposition in summer than in winter. Lazrus and others (1970) report daily lead deposition to range from $10 \mu \mathrm{g} / \mathrm{m}^{2}$ at a site in Minnesota to $460 \mu \mathrm{g} / \mathrm{m}^{2}$ in downtown Chicago, based on pooled monthly bulk samples collected predominantly from urban sites from September 1966 through March 1967.

The relatively low median value reported in this study suggests a reduction of lead loading, possibly from a combination of seasonally low deposition of lead in winter and a general 
FIGURE 17. - Distribution of ammonium deposition, December 1980 through February 1981.

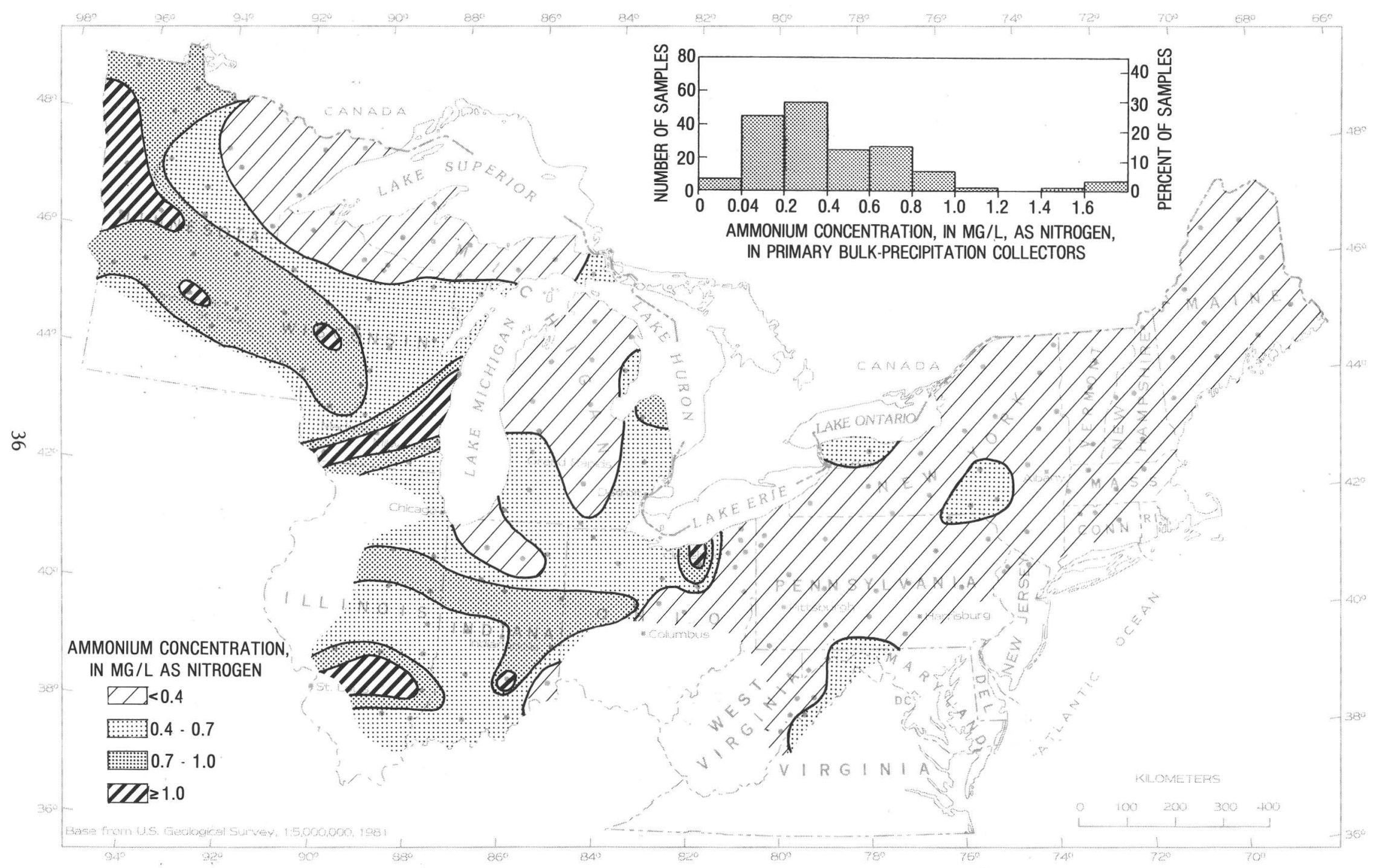

A, Concentration as nitrogen in milligrams per liter. 


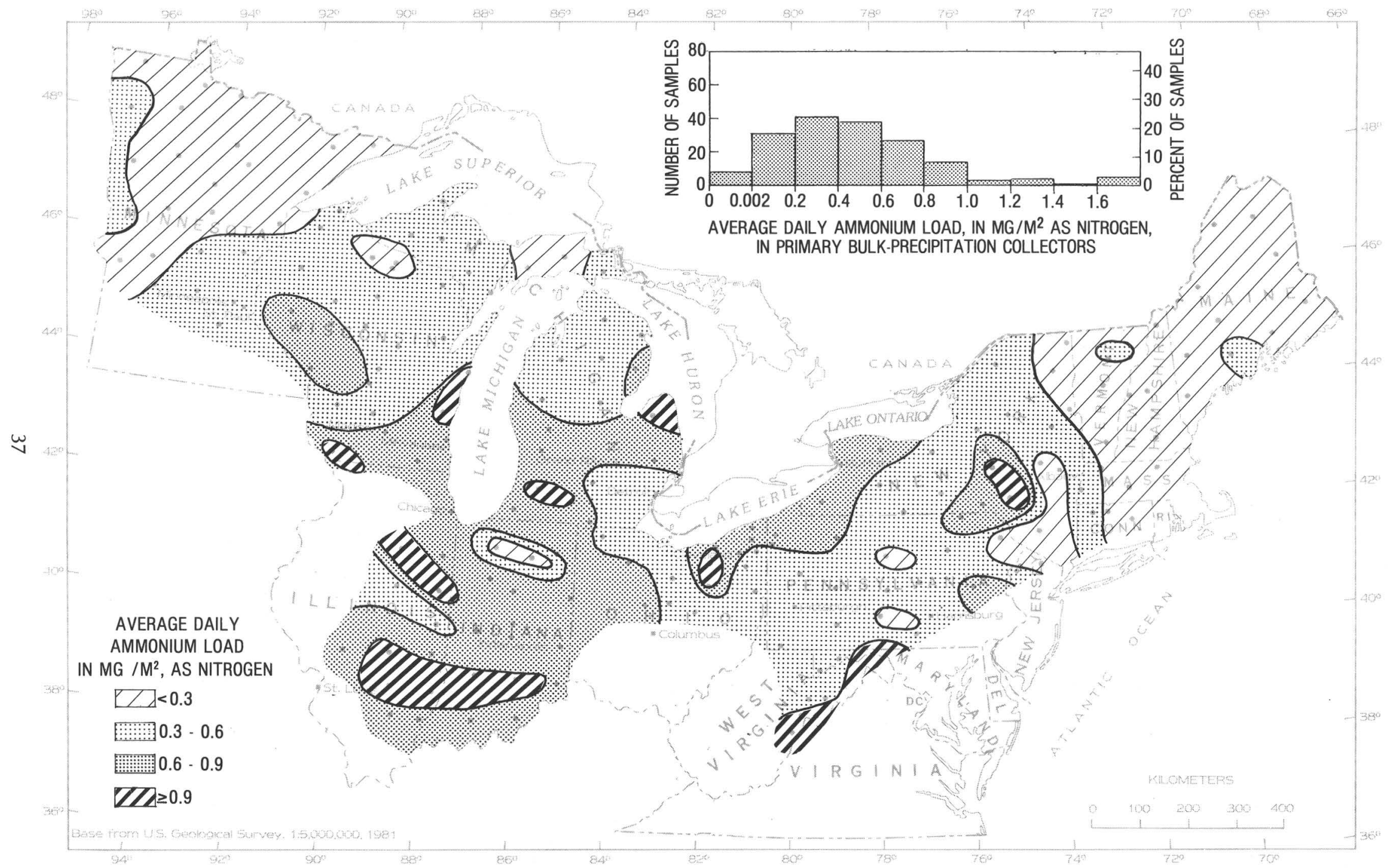

$B$, Daily loads as nitrogen in milligrams per square meter. 
FicURE 18. - Distribution of iron deposition, December 1980 thorugh February 1981.

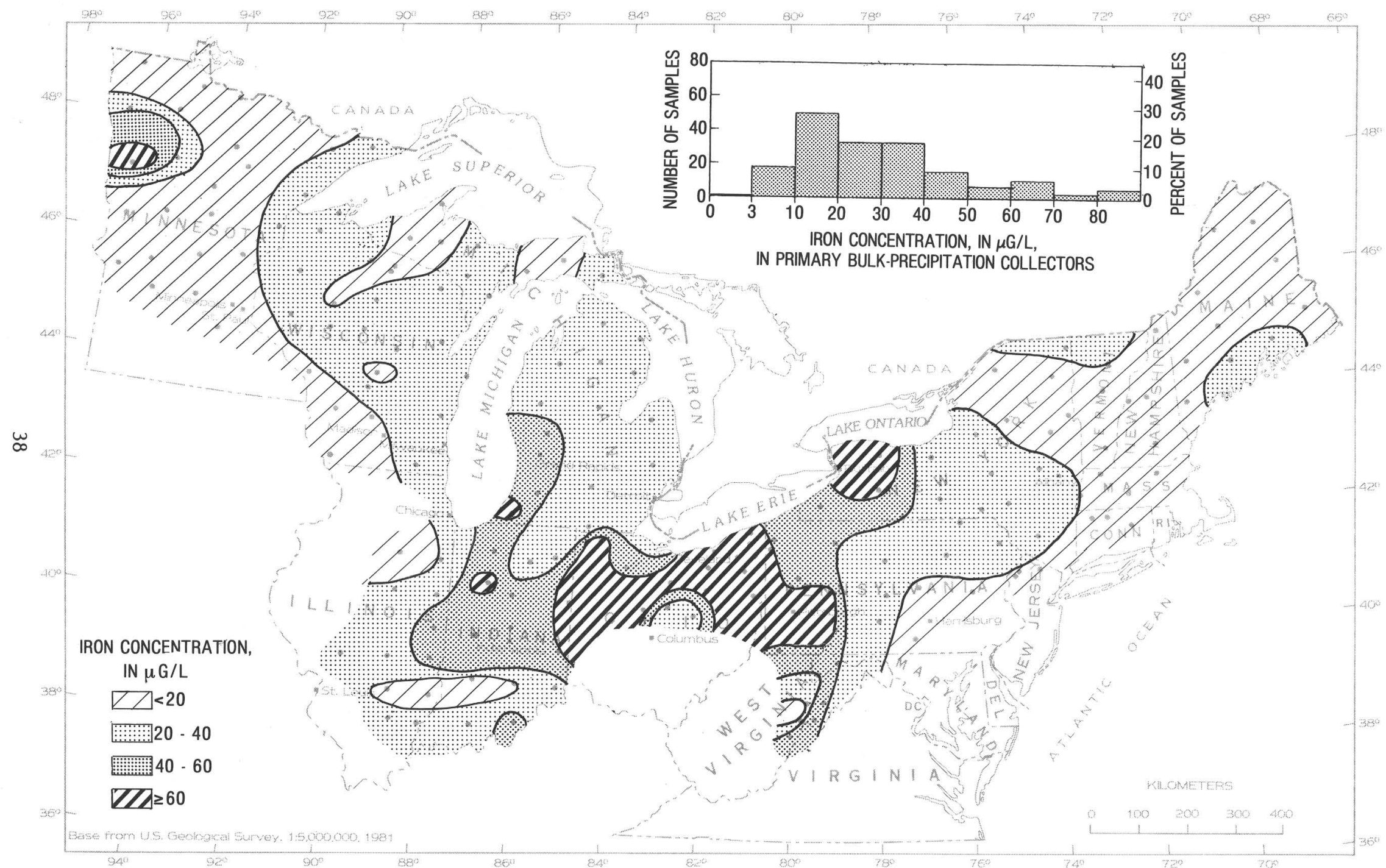

A, Concentration in micrograms per liter. 


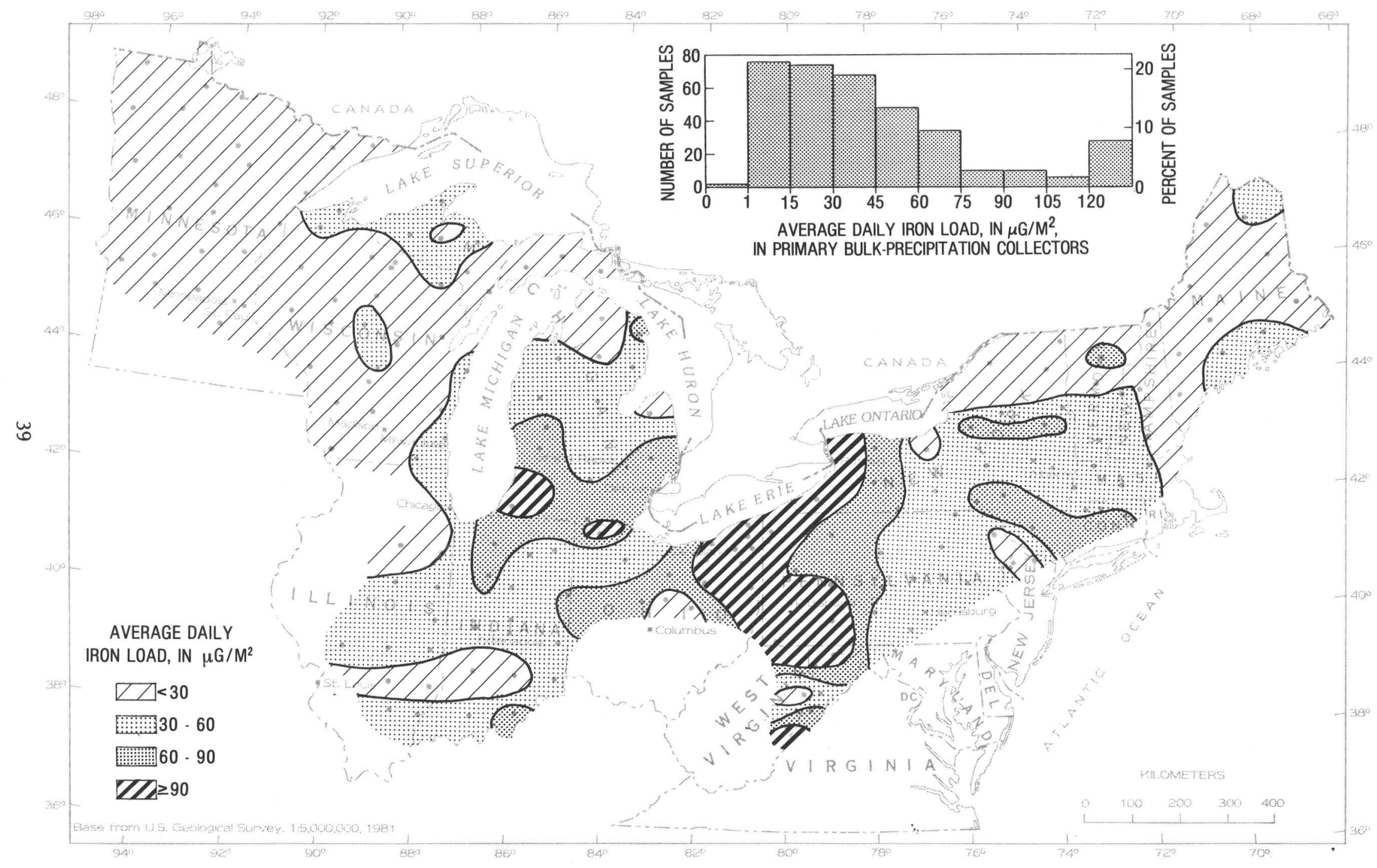

$B$, Daily loads in micrograms per square meter. 


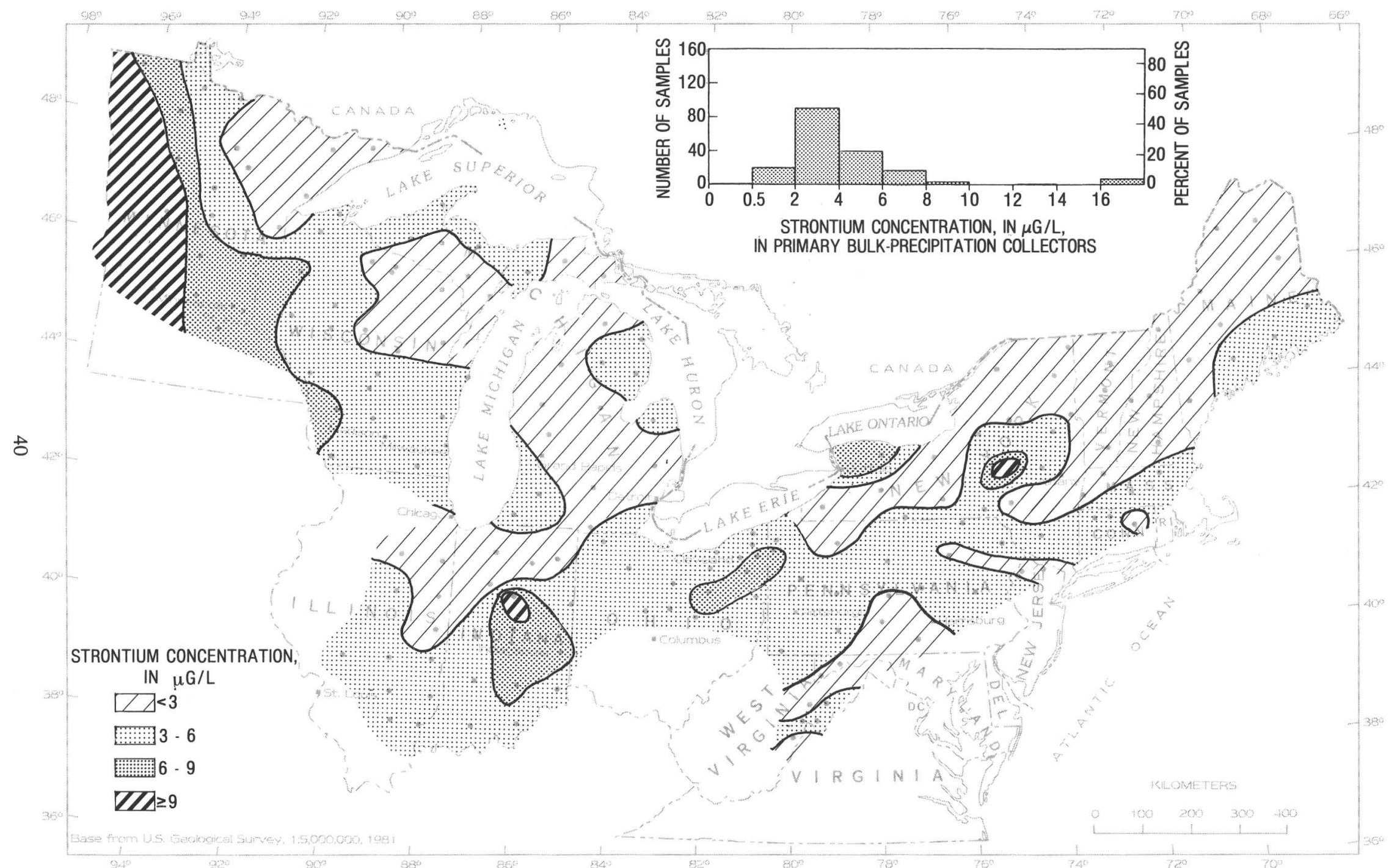




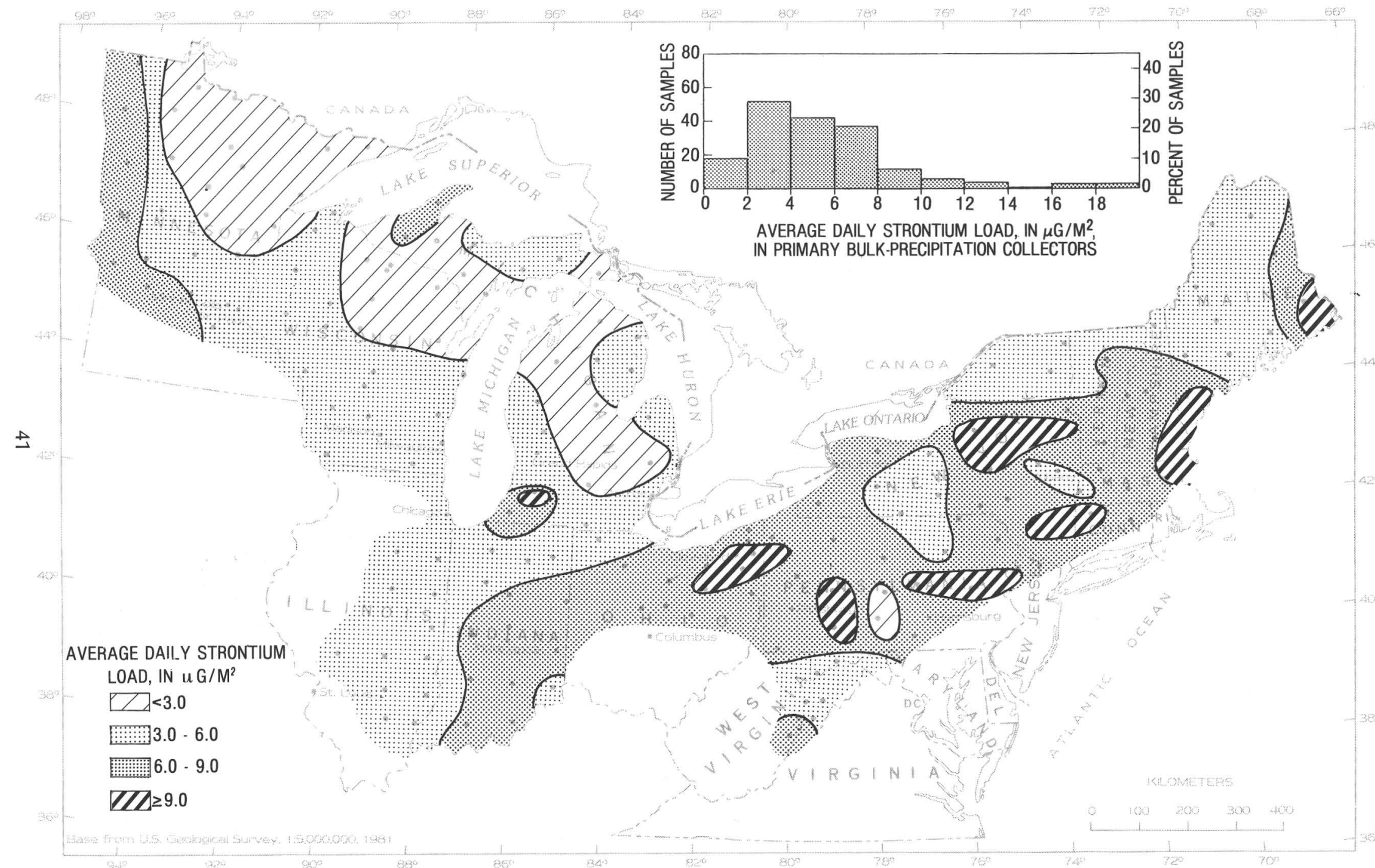

$B$, Daily loads in micrograms per square meter 


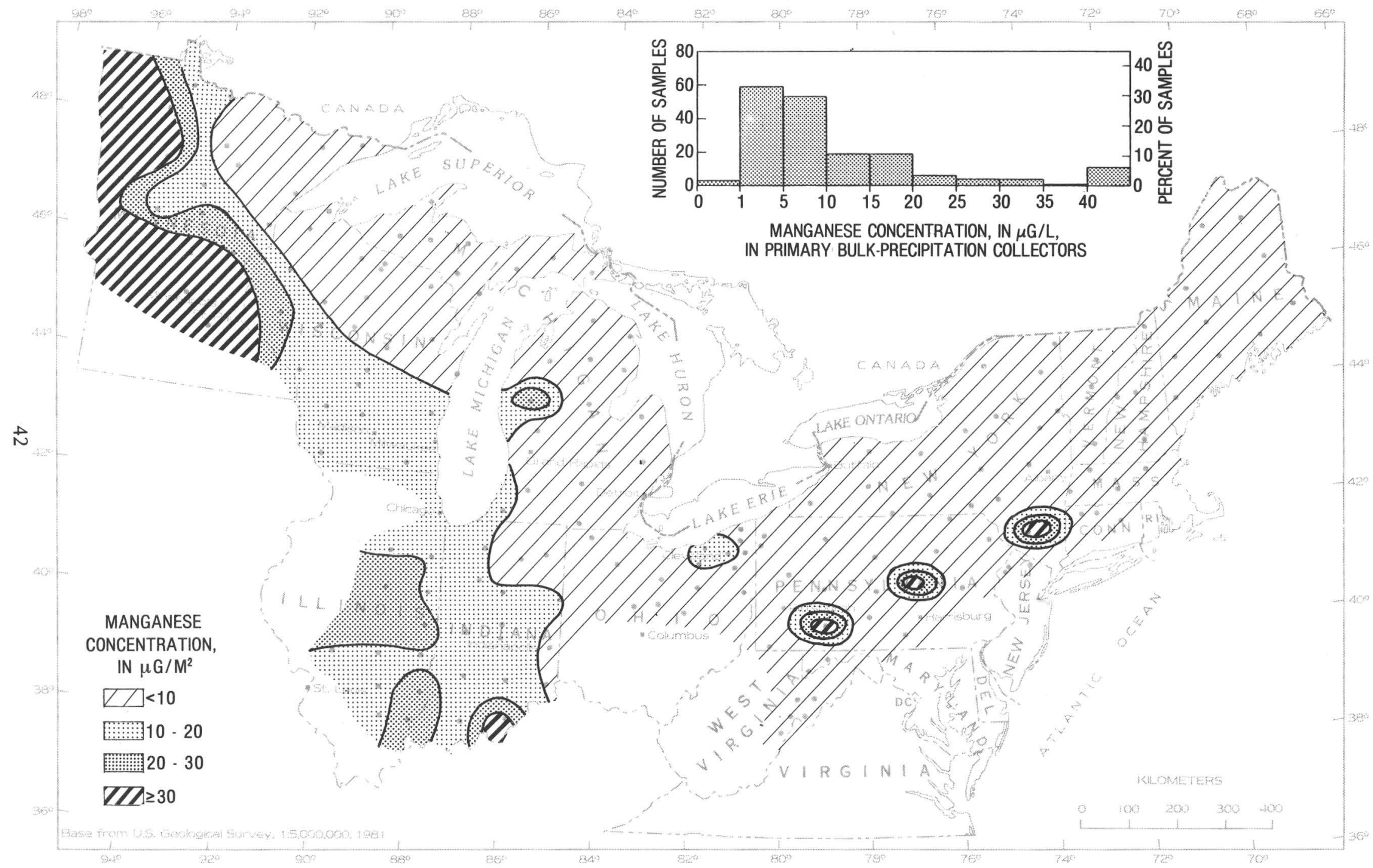

A, Concentration in micrograms per liter. 


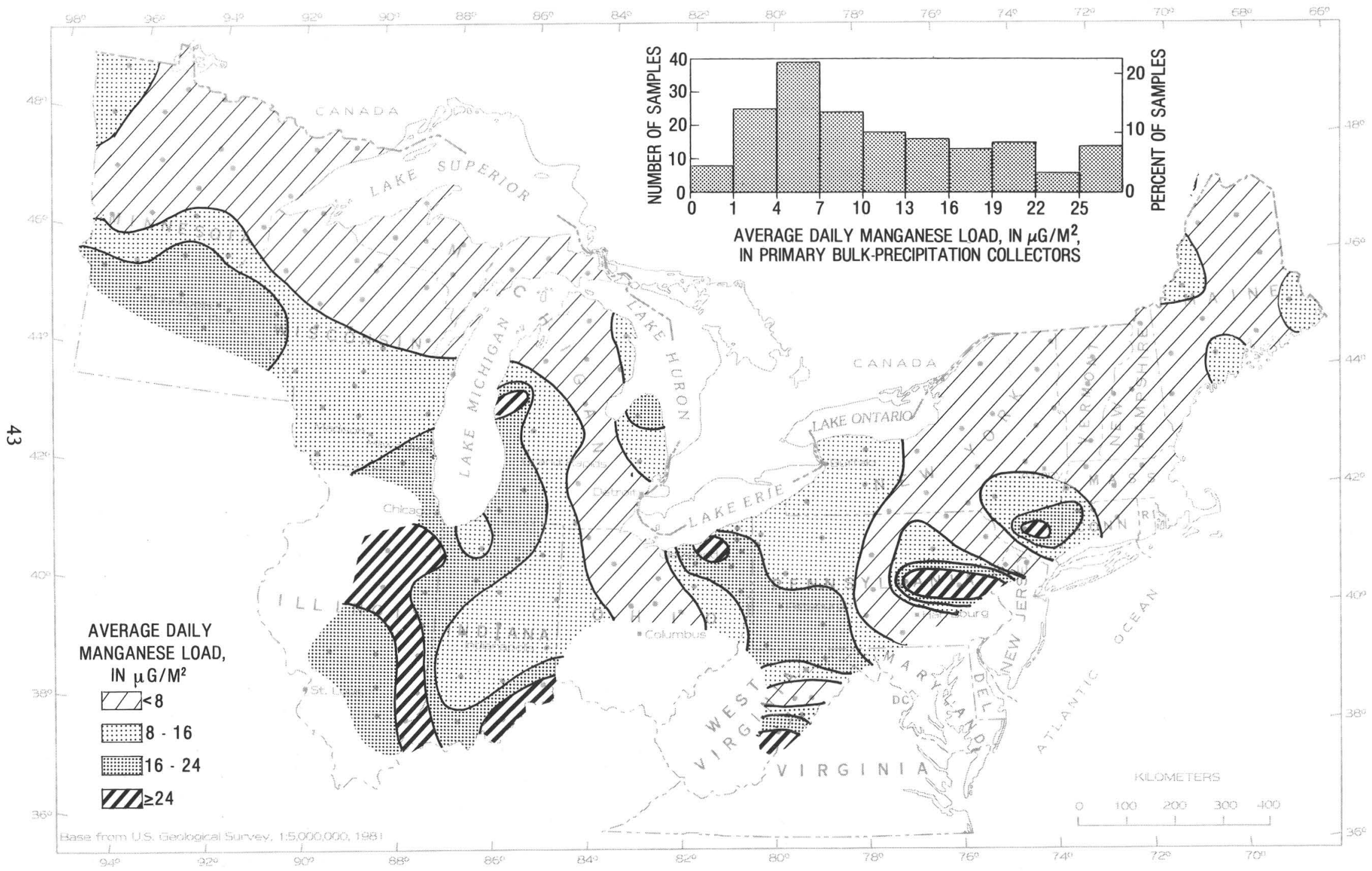

$B$, Daily loads in micrograms per square meter. 
national decrease in the consumption of leaded fuels.

\section{SUMMARY}

Bulk atmospheric deposition samples were collected at 179 sites from December 1980 through February 1981 in the Northeastern United States. Weather was atypical; both precipitation and air temperature were lower than average during the first 2 months and higher than normal during the last, when precipitation fell as rain in most of the area. The general air-circulation pattern during the period indicates that moisture was derived from the Atlantic Ocean and the Gulf of Mexico, with surface wind typically from west to east.

Concentrations and loads of the following dissolved constituents were determined for each sample: $\mathrm{As}, \mathrm{Ba}, \mathrm{Be}$, total inorganic carbon, $\mathrm{Ca}$, $\mathrm{Cd}, \mathrm{Cl}, \mathrm{Co}, \mathrm{Cu}, \mathrm{F}, \mathrm{Fe}, \mathrm{H}, \mathrm{Hg}, \mathrm{K}, \mathrm{Li}, \mathrm{Mg}, \mathrm{Mn}, \mathrm{Mo}$, $\mathrm{NH}_{4}-\mathrm{N}, \mathrm{NO}_{3}-\mathrm{N}, \mathrm{Na}, \mathrm{Ni}, \mathrm{Pb}, \mathrm{Se}, \mathrm{Si}, \mathrm{Sr}, \mathrm{SO}_{4}, \mathrm{~V}$, and $\mathrm{Zn}$. Replicate samples were collected from an additional collector at 10 percent of the sites, and 43 samples splits also were analyzed. Of the 29 constituents, 13 had an analytical and sampling plus analytical precision of 50 percent or less. Contour maps and histograms depict concentrations and loads for the following 12 constituents: $\mathrm{Na}, \mathrm{Cl}, \mathrm{Ca}, \mathrm{SO}_{4}, \mathrm{~F}, \mathrm{H}, \mathrm{NO}_{3}-\mathrm{N}, \mathrm{Pb}, \mathrm{Fe}$, $\mathrm{NH}_{4}-\mathrm{N}, \mathrm{Sr}$, and $\mathrm{Mn}$.

The maps of constituent loads display both banded and concentric regional distribution patterns. Sodium and chloride loads exemplify a simple banding pattern with a zone of high values along the coast, presumably a result of recycling of sea salt. The decrease to the northwest is steep initially but becomes gradual in the vicinity of Lake Michigan. This regional pattern is somewhat obscured by local highs near some major urban centers; these may reflect recycled highway salt.

Calcium and sulfate both show a general decrease from south to north. Fluoride, however, has a band of high loading with scattered peaks from Pennsylvania to east of the Twin Cities in Minnesota. These peaks are east (downwind) of major urban centers, and many of them correlate with the iron peaks.

Sites in western Pennsylvania and eastern Ohio had $\mathrm{pH}$ of less than 4.2 and large loads of hydrogen ion. The distribution pattern is concentric, with the highest $\mathrm{pH}$ in Minnesota and southern IIlinois.
Distribution pattrerns of nitrate, lead, and iron loads are similar to that of hydrogen ion. All have a center of high loading in eastern Ohio and western Pennsylvania; however, west of this center, the nitrate pattern differs from that of hydrogen ion but parallels that of ammonium.

Median daily loads of lead $\left(9 \mu \mathrm{g} / \mathrm{m}^{2}\right)$, zinc (18 $\left.\mu \mathrm{g} / \mathrm{m}^{2}\right)$, and iron $\left(34 \mu \mathrm{g} / \mathrm{m}^{2}\right)$ are lower than those reported from rural sites in North America (Jeffries and Snyder, 1981). Lead deposition seems to have been decreasing with time, possibly as a result of decreased consumption of leaded fuels. The low lead value obtained during the winter of 1980-81 also may be related partly to seasonal lows, as reported by other researchers.

\section{REFERENCES CITED}

Babich, Harvey, Davis, D. L., and Stotzky, Guenther, 1980, Acid precipitation, causes and consequence: Environment, v. 22, no. 4, p. 6-13.

Cohen, A. C., Jr., 1959, Simplified estimators for the normal distribution when samples are singly censored or truncated: Technometrics, v. 1, no. 3, p. 217-237.

Dickson, R. R., 1981, Weather and circulation of February 1980: Monthly Weather Review, v. 109, no. 5, p. $1130-1135$.

Fishman, M. J., and Pyen, G., 1979, Determination of selected anions in water by ion chromatography: U.S. Geological Survey Water-Resources Investigations 79-101, $30 \mathrm{p}$.

Galloway, J. N., and Likens, G. E., 1978, The collection of precipitation for chemical analysis: Tellus, v. 30, p. $71-82$.

1981, Acid precipitation-The importance of nitric acid: Atmospheric Environment, v. 15, no. 6 , p. 1,081-1,085.

Galloway, J. N., Likens, G. E., and Edgerton, E. S., 1976, Hydrogen ion speciation in the acid precipitation of the Northeastern United States: Water, Air, and Soil Pollution, v. 6, p. 423-433.

Carbarino, J. R., and Taylor, H. E., 1979, An inductive-coupled plasma atomic emission spectrometric method for routine water-quality testing: Applied Spectroscopy, v. 33, no. 3, p. 220-226.

Glass, G. E., and Brydges, T. G., in press, Problem complexity in predicting impacts from altered precipitation chemistry, in T. Harnes (ed.), Proceedings of the Acid Rain/Fisheries Symposium, August 2-5, 1981, Cornell University, Ithaca, New York: Bethesda, Md., American Fisheries Society.

Hileman, Bette, 1981, Acid precipitation: Environment Science and Technology, v. 15, no. 10, p. 1119-1124. 
Jackson, D. D., 1905, The normal distribution of chlorine in natural waters of New York and New England: U.S. Geological Survey Water-Supply Paper 144, $31 \mathrm{p}$.

Jeffries, D. S., and Snyder, W. R., 1981, Atmospheric deposition of heavy metals in central Ontario: Water, Air, and Soil Pollution, v. 15, p. 127-152.

Junge, C. E., 1958, The distribution of ammonia and nitrate in rain water over the United States: Transactions, American Geophysical Union, v. 39, no. 2 , p. 241-248.

Krige, D. G., 1960, On the departure of ore value distributions from the log-normal model in South African gold mines: South African Institute Mining Metallurgy Journal, v. 61, no. 4, p. 231-244.

Lazrus, A. L., Lorange, E., and Lodge, J. P., 1970, Lead and other metal ions in United States precipitation: Environmental Science and Technology, v. 4, no. 1, p. 55-58.

Likens, G. E., 1976, Acid precipitation: Chemical and Engineering News, v. 54, no. 48, p. 29-44.

McColl, J. G., 1980, A survey of acid precipitation in northern California: Final Research Project Report for California Air Resources Board, Contract A7-149-30, and Agricultural Experiment Station, University of California at Berkeley, Project CA-B-SPN-3664-H, $94 \mathrm{p}$.

Natural Resource Ecology Laboratory, 1978-81, NADP data report, precipitation chemistry: Fort Collins, Colo., Colorado State University, v. 1, no. $1-v .4$, no. 1 (issued quarterly).

Siccama, T. G., and Smith, W. H., 1978, Lead accumulation in a northern hardwood forests: Environmental Science and Technology, v. 12, no. 5 , p. 593-594.

Sichel, H. S., 1952, New methods in the statistical evaluation of mine sampling data: London, Institution of Mining Metallurgy Transactions, v. 61, p. 261-288.
Skougstad, M. W., Fishman, M. J., Friedman, L. C., Erdmann, D. E., and Duncan, S. S. (eds.), 1979, Methods for determination of inorganic substances in water and fluvial sediments: U.S. Geological Survey, Techniques of Water-Resources Investigations, bk. 5, chap. A1.

Taubensee, R. E., 1981, Weather and circulation of December 1980: Monthly Weather Review, v. 109. no. 3, p. 676-682.

Troutman, D. E., and Peters, N. E., 1982, Deposition and transport of heavy metals in three lake basins affected by acid precipitation in the Adirondack Mountains, New York, in L. H. Keith (ed.), Energy and Environmental Chemistry, v. 2: Washington, D.C., American Chemical Society, p. 33-61.

U.S. Bureau of Mines, 1977, Minerals yearbook 1975, Volume I, Metals, minerals and fuels: Washington, D.C., Bureau of Mines, p. 635-638.

U.S. Geological Survey, 1970, The national atlas of the United States: Washington, D.C., U.S. Geological Survey, $417 \mathrm{p}$.

U.S. National Oceanic and Atmospheric Administration, 1980-81, Climatological data for Illinois, Indiana, Maryland, Michigan, Minnesota, New England, New Jersey, New York, Ohio, Pennsylvania, West Virginia, and Wisconsin: Ashville, N.C., National Climatic Center, v. 92, no. 11 through v. 93, no. 3.

U.S. National Oceanic and Atmospheric Administration and U.S. Department of Agriculture, 1981, [Maps showing] Temperature departure $\left({ }^{\circ} \mathrm{F}\right)$ from 30 -year mean and percentage of normal precipitation: Weekly Weather and Crop Bulletin, v. 68, nos. 1, 6, and 10.

Wagner, A. J., 1981, Weather and circulation of January 1981: Monthly Weather Review, v. 109, no. 4, p. $920-928$. 
TABLE 4. - Descriptions of bulk-precipitation-collection sites

\begin{tabular}{|c|c|c|c|c|c|c|c|c|c|c|c|}
\hline $\begin{array}{l}\text { Lat1- } \\
\text { tude }\end{array}$ & $\begin{array}{l}\text { Long1- } \\
\text { tude }\end{array}$ & County & State & $\begin{array}{l}\text { Sample } \\
\text { identi- } \\
\text { fication } \\
\text { number }\end{array}$ & $\begin{array}{c}\text { Sample1/ } \\
\text { type }\end{array}$ & $\begin{array}{l}\text { Instal- } \\
\text { lation } \\
\text { date }\end{array}$ & $\begin{array}{l}\text { Collec- } \\
\text { tion } \\
\text { date } \\
\end{array}$ & $\begin{array}{c}\text { Sample } \\
\text { volume } \\
\text { (liters) }\end{array}$ & $\begin{array}{c}\text { Estimated } \\
\text { sample } \\
\text { volume } \\
\text { (11ters) } \\
\end{array}$ & $\begin{array}{l}\text { Site } \\
\text { eleva- } \\
\text { t1on } \\
\text { (feet) }\end{array}$ & Land use \\
\hline $\begin{array}{l}451040 \\
460310 \\
444350\end{array}$ & $\begin{array}{l}674630 \\
682138 \\
683936\end{array}$ & $\begin{array}{l}\text { Washing ton } \\
\text { Aroos tock } \\
\text { Penobscot }\end{array}$ & $\begin{array}{l}\text { ME } \\
\text { do. } \\
\text { do. }\end{array}$ & $\begin{array}{l}\text { NE12 } \\
\text { NE17 } \\
\text { NE09 }\end{array}$ & $\begin{array}{l}\mathbf{P} \\
\mathbf{P} \\
\mathbf{P}\end{array}$ & $\begin{array}{l}11-19-80 \\
12-01-80 \\
12-01-80\end{array}$ & $\begin{array}{l}03-11-81 \\
03-18-81 \\
03-12-81\end{array}$ & $\begin{array}{l}45.1 \\
20.4 \\
30.8\end{array}$ & $\begin{array}{l}54.8 \\
41.6 \\
24.5\end{array}$ & $\begin{array}{l}290 \\
760 \\
420\end{array}$ & $\begin{array}{l}\text { Fish hatchery } \\
\text { Agricultural } \\
\text { Rural residential }\end{array}$ \\
\hline 464426 & 684521 & Aroos tock & do. & $\mathrm{NE} 18$ & $\mathbf{P}$ & $12-02-80$ & $03-20-81$ & 20.4 & 39.3 & 840 & Woodland \\
\hline $\begin{array}{l}442736 \\
464200\end{array}$ & $\begin{array}{l}694028 \\
694259\end{array}$ & $\begin{array}{l}\text { Kennebec } \\
\text { Aroos took }\end{array}$ & $\begin{array}{l}\text { do. } \\
\text { do. }\end{array}$ & $\begin{array}{l}\text { NE1 1 } \\
\text { NE14 }\end{array}$ & $\begin{array}{l}\mathbf{P} \\
\mathbf{P}\end{array}$ & $\begin{array}{l}12-01-80 \\
11-20-80\end{array}$ & $\begin{array}{l}03-05-81 \\
03-19-81\end{array}$ & $\begin{array}{l}24.9 \\
31.3\end{array}$ & $\begin{array}{l}21.3 \\
32.2\end{array}$ & $\begin{array}{l}250 \\
980\end{array}$ & $\begin{array}{l}\text { Agricultural } \\
\text { Woodland }\end{array}$ \\
\hline $\begin{array}{l}450420 \\
453938\end{array}$ & $\begin{array}{l}695412 \\
701612\end{array}$ & $\begin{array}{l}\text { Somerset } \\
\text { do. }\end{array}$ & do. & $\begin{array}{l}\text { NE13 } \\
\text { NE15 }\end{array}$ & $\begin{array}{l}\mathbf{P} \\
\mathbf{P}\end{array}$ & $\begin{array}{l}12-02-80 \\
11-21-80\end{array}$ & $\begin{array}{l}03-10-81 \\
03-10-81\end{array}$ & $\begin{array}{l}22.7 \\
24.9\end{array}$ & $\begin{array}{l}31.3 \\
21.9\end{array}$ & $\begin{array}{r}485 \\
1,360\end{array}$ & $\begin{array}{l}\text { Agricul tural } \\
\text { Woodland }\end{array}$ \\
\hline 442950 & 704144 & Oxford & do. & NE16 & $\mathbf{P}$ & $11-25-80$ & $03-11-81$ & 34.9 & 36.8 & 650 & Do. \\
\hline 434835 & 704653 & Cumberland & do. & NE10 & $\mathbf{P}$ & $11-28-80$ & $02-26-81$ & 40.8 & 51.6 & 280 & Do. \\
\hline $\begin{array}{l}450250 \\
430912\end{array}$ & $\begin{array}{l}712300 \\
713634\end{array}$ & $\begin{array}{l}\text { Coos } \\
\text { Merrimack }\end{array}$ & $\begin{array}{l}\text { NH } \\
\text { do. }\end{array}$ & $\begin{array}{l}\text { NE03 } \\
\text { NE02 }\end{array}$ & $\begin{array}{l}\mathbf{P} \\
\mathbf{P}\end{array}$ & $\begin{array}{l}12-02-80 \\
11-28-80\end{array}$ & $\begin{array}{l}03-11-81 \\
03-06-81\end{array}$ & $\begin{array}{l}16.3 \\
44.9\end{array}$ & $\begin{array}{l}30.6 \\
40.2\end{array}$ & $\begin{array}{r}1,300 \\
350\end{array}$ & $\begin{array}{l}\text { Do. } \\
\text { Rural residential }\end{array}$ \\
\hline 430912 & 713634 & do. & do. & NEO1 & $\mathrm{R}$ & $11-28-80$ & $03-06-81$ & 44.9 & 40.2 & 350 & Do. \\
\hline $\begin{array}{l}423824 \\
435651\end{array}$ & $\begin{array}{l}713919 \\
714230\end{array}$ & $\begin{array}{l}\text { Middlesex } \\
\text { Grafton }\end{array}$ & $\begin{array}{l}\text { MA } \\
\text { NH }\end{array}$ & $\begin{array}{l}\text { NE20 } \\
\text { NE06 }\end{array}$ & $\begin{array}{l}\mathrm{P} \\
\mathrm{P}\end{array}$ & $\begin{array}{l}12-12-80 \\
12-01-80\end{array}$ & $\begin{array}{l}03-09-81 \\
03-10-81\end{array}$ & $\begin{array}{l}22.9 \\
45.4\end{array}$ & $\begin{array}{l}36.4 \\
52.8\end{array}$ & $\begin{array}{l}270 \\
760\end{array}$ & $\begin{array}{l}\text { Alrfield } \\
\text { Woodland }\end{array}$ \\
\hline 435422 & 720923 & Orange & VT & NE08 & P & $12-05-80$ & $03-12-81$ & 37.2 & 36.0 & 440 & Agricultural \\
\hline 414755 & 722056 & Tolland & $\mathrm{CN}$ & NE2 2A & $\mathbf{P}$ & $11-25-80$ & $03-02-81$ & 45.2 & 48.7 & 485 & Do. \\
\hline 414755 & 722056 & do. & do. & NE2 2B & $\mathbf{R}$ & $11-25-80$ & $03-02-81$ & 45.2 & 48.7 & 485 & Do. \\
\hline 421959 & 722104 & llampshire & MA & NE21 & $\mathbf{P}$ & $12-09-80$ & $03-11-81$ & 35.4 & 36.6 & 530 & Woodland \\
\hline 443355 & 723431 & Lamof1le & VT & NE07 & $\mathbf{P}$ & $12-01-80$ & $03-09-81$ & 34.9 & 41.5 & 640 & Agricult ural \\
\hline 440620 & 724445 & Washing ton & do. & NEO4 & $\mathrm{P}$ & $12-01-80$ & $03-09-81$ & 43.5 & 47.5 & 1,100 & Woodland \\
\hline 430725 & 724636 & W1 ndham & do. & NE05 & $\mathbf{P}$ & $12-01-80$ & $03-09-81$ & 45.4 & 55.3 & 1,100 & Do. \\
\hline 415648 & 725017 & Hartford & CN & NE 23 & $\mathbf{P}$ & $11-26-80$ & $03-02-81$ & 53.2 & 42.7 & 325 & Agricultural \\
\hline 424102 & 725659 & Frank11n & MA & NE 19 & $\mathbf{P}$ & $12-10-80$ & $03-12-81$ & 42.0 & 52.5 & 1,500 & Rallroad switch yard \\
\hline 415823 & 731313 & Litchfield & $\mathrm{CN}$ & NE 24 & $\mathrm{P}$ & $11-26-80$ & $03-02-81$ & 41.8 & 62.7 & 1,335 & Woodland \\
\hline 434310 & 732802 & Washing ton & $\mathrm{NY}$ & NY14 & $\mathbf{P}$ & $12-04-80$ & $03-02-81$ & 29.8 & 36.7 & 350 & Do. \\
\hline 445406 & 732930 & Clinton & do. & NY06 & $\mathbf{P}$ & $11-21-80$ & $03-03-81$ & 23.5 & 21.3 & 210 & Agricultural \\
\hline 422211 & 733010 & Columbia & do. & NY05 & P & $12-03-80$ & $03-19-81$ & 22.5 & 39.1 & 1,330 & Woodland \\
\hline 442405 & 735121 & Essex & do. & NY20 & $P$ & $11-20-80$ & $03-03-81$ & 24.3 & 45.5 & 2,050 & Do. \\
\hline 442405 & 735121 & do. & do. & NY25 & R & $11-20-80$ & $03-03-81$ & 22.5 & 45.5 & 2,050 & Do. \\
\hline 442405 & 735121 & do. & do. & NY37A & A & $11-20-80$ & $12-22-80$ & 1.0 & 11.3 & 2,050 & Do. \\
\hline 442405 & 735121 & do. & do. & NY37B & B & $12-22-80$ & $01-12-81$ & .5 & 1.5 & 2,050 & Do. \\
\hline 442405 & 735121 & do. & do. & NY37C & $\mathrm{C}$ & $01-12-81$ & $02-02-81$ & .7 & 3.0 & 2,050 & Do. \\
\hline 442405 & 735121 & do. & do. & NY21 & D & $02-02-81$ & $03-03-81$ & 19.6 & 29.7 & 2,050 & Do. \\
\hline 442405 & 735121 & do. & do. & NY23 & $S$ & -- & $03-03-81$ & -- & -- & 2,050 & Do. \\
\hline 432715 & 740025 & Warren & do. & NY13 & $P$ & $11-30-80$ & $03-01-81$ & 50.3 & 52.0 & 1,600 & Agricultural \\
\hline 424708 & 741955 & Montgomery & do. & NY19 & $\mathbf{P}$ & $12-07-80$ & $03-04-81$ & 18.4 & 22.2 & 1,340 & Do. \\
\hline $\begin{array}{l}424708 \\
424708\end{array}$ & $\begin{array}{l}741955 \\
741955\end{array}$ & $\begin{array}{l}\text { do. } \\
\text { do. }\end{array}$ & $\begin{array}{l}\text { do. } \\
\text { do. }\end{array}$ & $\begin{array}{l}\text { NY28 } \\
\text { NY26 }\end{array}$ & $\begin{array}{l}\mathrm{R} \\
\mathrm{S}\end{array}$ & $\begin{array}{c}12-07-80 \\
\rightarrow\end{array}$ & $\begin{array}{l}03-04-81 \\
03-04-81\end{array}$ & 19.3 & $\begin{array}{c}22.2 \\
--\end{array}$ & $\begin{array}{l}1,340 \\
1,340\end{array}$ & $\begin{array}{l}\text { Do. } \\
\text { Do. }\end{array}$ \\
\hline 410921 & 742651 & Sussex & NJ & NJOl & $\mathbf{P}$ & $12-15-80$ & $03-04-81$ & 38.2 & 32.3 & 1,320 & Woodland \\
\hline $\begin{array}{l}414158 \\
434224\end{array}$ & $\begin{array}{l}742714 \\
745428\end{array}$ & $\begin{array}{l}\text { Ulster } \\
\text { Herkiner }\end{array}$ & $\begin{array}{l}\text { NY } \\
\text { do. }\end{array}$ & $\begin{array}{l}\text { NY09 } \\
\text { NY16 }\end{array}$ & $\begin{array}{l}\mathbf{P} \\
\mathbf{P}\end{array}$ & $\begin{array}{l}11-25-80 \\
12-02-80\end{array}$ & $\begin{array}{l}03-06-81 \\
03-04-81\end{array}$ & $\begin{array}{r}4.6 \\
35.2\end{array}$ & $\begin{array}{l}42.7 \\
36.2\end{array}$ & $\begin{array}{l}1,250 \\
1,925\end{array}$ & $\begin{array}{l}\text { Agricultural } \\
\text { Woodland }\end{array}$ \\
\hline 434224 & 745428 & do. & do. & NY24 & $\mathbf{R}$ & $12-02-80$ & $03-04-81$ & 4.9 & 36.2 & 1,925 & Do. \\
\hline 410547 & 745800 & Sussex & $\mathrm{NJ}$ & NJ02 & $\mathbf{P}$ & $12-24-80$ & $03-03-81$ & 30.7 & 25.3 & 400 & Do. \\
\hline 410547 & 745800 & do. & do. & NJ04 & $\mathbf{R}$ & $12-10-80$ & $03-03-81$ & 32.5 & 25.3 & 400 & Do. \\
\hline 410547 & 745800 & do. & do. & NJ05A & A & $12-10-80$ & $12-24-80$ & 3.0 & 2.0 & 400 & Do. \\
\hline 410547 & 745800 & do. & do. & NJOSB & B & $12-24-80$ & $01-12-81$ & 2.5 & 1.0 & 400 & Do. \\
\hline 410547 & 745800 & do. & do. & $\mathrm{NJ} 05 \mathrm{C}$ & D & $02-03-81$ & $03-03-81$ & 18.6 & 22.3 & 400 & Do. \\
\hline
\end{tabular}


TABLE 4. - Descriptions of bulk-precipitation-collection sites-Continued

\begin{tabular}{|c|c|c|c|c|c|c|c|c|c|c|c|}
\hline $\begin{array}{l}\text { Lati- } \\
\text { tude }\end{array}$ & $\begin{array}{l}\text { Long1- } \\
\text { tude }\end{array}$ & County & State & $\begin{array}{l}\text { Sample } \\
\text { identi- } \\
\text { fication } \\
\text { number }\end{array}$ & $\begin{array}{c}\text { Sample } \\
\text { type }\end{array}$ & $\begin{array}{l}\text { Instal- } \\
\text { lation } \\
\text { date }\end{array}$ & $\begin{array}{l}\text { Collec- } \\
\text { tion } \\
\text { date } \\
\end{array}$ & $\begin{array}{c}\text { Sample } \\
\text { volume } \\
\text { (1iters) }\end{array}$ & $\begin{array}{c}\text { Estimated } \\
\text { sample } \\
\text { volume } \\
\text { (1iters) }\end{array}$ & $\begin{array}{l}\text { Site } \\
\text { eleva- } \\
\text { tion } \\
\text { (feet) } \\
\end{array}$ & Land use \\
\hline 410219 & 745945 & Warren & $\mathrm{NJ}$ & NJ03 & $\mathbf{p}$ & $12-24-80$ & $03-03-81$ & 32.5 & 33.6 & 1,210 & Woodland \\
\hline 421710 & 750538 & Delaware & NY & NY10 & $\mathbf{P}$ & $11-26-80$ & $03-05-81$ & 24.3 & 42.0 & 1,880 & Do. \\
\hline 443535 & 751353 & St. Lawrence & e do. & NY04 & $\mathbf{p}$ & $12-08-80$ & $03-03-81$ & 15.9 & 21.6 & 330 & Wetland \& Rural residential \\
\hline 413519 & 751954 & Wayne & PA & PA18 & $\mathbf{P}$ & $11-20-80$ & $03-02-81$ & -- & 38.18 & 2,809 & Agricultural \& Woodland \\
\hline 413519 & 751954 & do. & do. & PA08 & $\mathbf{R}$ & $11-20-80$ & $03-02-81$ & -- & 38.18 & 2,809 & Do. \\
\hline 424854 & 752634 & Madison & $\mathrm{NY}$ & NY07 & $\mathbf{p}$ & $12-15-80$ & $03-02-81$ & 3.2 & 19.4 & 1,200 & Do. \\
\hline 421225 & 754242 & Jefferson & do. & NYOI & p & $12-10-80$ & $03-03-81$ & 16.4 & 26.4 & 440 & Agricultural \\
\hline 432842 & 754438 & Lewis & do. & NY17 & $\mathbf{P}$ & $12-11-80$ & $03-03-81$ & 21.7 & 37.8 & 1,260 & Do. \\
\hline 404826 & 760030 & Schuylkill & PA & PA07 & $\mathbf{P}$ & $12-04-80$ & $03-02-81$ & -- & 53.8 & 1,110 & Woodland \\
\hline 420126 & 761318 & Tloga & NY & NYO2 & $\mathbf{P}$ & $12-11-80$ & $03-02-81$ & 20.9 & 24.3 & 1,610 & Agricultural \& Woodland \\
\hline 412821 & 763455 & Sullivan & PA & PA10 & $\mathrm{P}$ & $11-28-80$ & $03-02-81$ & - & 30.2 & 1,170 & Woodland \\
\hline 422358 & 763913 & Tompkins & $\mathrm{NY}$ & NYI1 & P & $12-16-80$ & $03-02-81$ & 22.7 & 20.0 & 1,700 & Agricultural \& Woodland \\
\hline 422358 & 763913 & do. & do. & $\mathrm{NY} 27$ & $\mathbf{R}$ & $12-16-80$ & $03-02-81$ & 18.0 & 20.0 & 1,700 & Do. \\
\hline 422358 & 7639.13 & do. & do. & NY22A & A & $12-16-80$ & $12-22-80$ & 0.7 & 1.4 & 1,700 & Do. \\
\hline 422358 & 763913 & do. & do. & NY22B & B & $12-22-80$ & $01-12-81$ & 4.5 & 3.6 & 1,700 & Do. \\
\hline 422358 & 763913 & do, & do. & NY22C & $\mathrm{C}$ & $01-12-81$ & $02-03-81$ & 0.4 & 5.4 & 1,700 & Do. \\
\hline 422358 & 763913 & do. & do. & NY22D & D & $02-03-81$ & $03-02-81$ & 9.5 & 9.6 & 1,700 & Do. \\
\hline 422358 & 763913 & do. & do. & NY30 & s & - & $03-02-81$ & -- & -- & 1,700 & Do. \\
\hline 430653 & 764829 & Wayne & do. & NY15 & $\mathbf{P}$ & $12-12-80$ & $03-02-81$ & 22.7 & 17.0 & 440 & Do. \\
\hline 405452 & 771310 & Union & PA & PA13 & $\mathbf{P}$ & $11-25-80$ & $03-02-81$ & - & 43.3 & 1,040 & Woodland \\
\hline 400147 & 771741 & Cumberland & do. & PAl 4 & $\mathrm{P}$ & $11-21-80$ & $03-03-81$ & -- & 47.8 & 910 & Do, \\
\hline 420630 & 773206 & Steuben & $\mathrm{NY}$ & NY12 & $\mathbf{P}$ & $12-02-80$ & $03-02-81$ & $21 \cdot 3$ & 22.7 & 1,980 & Agricultural \& Woodland \\
\hline 412121 & 775532 & Clinton & PA & PA09 & $\mathbf{P}$ & $11-25-80$ & $03-02-81$ & -- & 33.6 & 850 & Woodland \\
\hline 404718 & 775643 & Centre & do. & PA15 & $\mathrm{P}$ & $11-24-80$ & $03-02-81$ & -- & 33.6 & 1,300 & Do. \\
\hline 404718 & 775643 & do. & do. & PAI1 & $\mathbf{R}$ & $11-24-80$ & $03-02-81$ & -- & 33.6 & 1,300 & Do. \\
\hline $\begin{array}{l}404718 \\
404718\end{array}$ & 775643 & do. & do. & PA16 & A & $\begin{array}{l}11-24-80 \\
12-22-80\end{array}$ & $\begin{array}{l}12-22-80 \\
01-12-81\end{array}$ & - & $\begin{array}{l}6.4 \\
3.5\end{array}$ & 1,300 & Do. \\
\hline 404718 & 775643 & do. & do. & PA20 & B & $12-22-80$ & $01-12-81$ & -- & 3.5 & 1,300 & Do. \\
\hline 404718 & 775643 & do. & do. & PA17 & C & $01-12-80$ & $02-02-80$ & -- & 2.8 & 1,300 & Do. \\
\hline 404718 & 775643 & do. & do. & PA19 & D & $02-02-80$ & $03-02-80$ & -- & 20.8 & 1,300 & Do. \\
\hline 431028 & 780108 & Orleans & NY & NY03 & $\mathbf{P}$ & $12-08-80$ & $03-02-81$ & 18.1 & 16.8 & 670 & Agricultural \\
\hline 423315 & 780435 & Wyoming & do. & NY18 & $\mathbf{P}$ & $12-04-80$ & $03-02-81$ & 22.7 & 21.2 & 1,600 & Woodland \\
\hline 402043 & 780639 & Huntingdon & PA & PA12 & $\mathbf{P}$ & $11-20-80$ & $03-03-81$ & -- & 22.8 & 1,600 & Agricultural \\
\hline 414138 & 790322 & Warren & do. & $\mathrm{PAO2}$ & $\mathbf{P}$ & $11-25-80$ & $03-02-81$ & -- & 33.9 & 1,900 & Do. \\
\hline 393621 & 790335 & Garrett & MD & MD07 & $\mathbf{P}$ & $12-04-80$ & $03-02-81$ & 21.9 & 34.3 & 2,460 & Do. \\
\hline 401210 & 790500 & Somerset & PA & $\mathrm{PAO} 4$ & $\mathbf{P}$ & $11-19-80$ & $03-02-81$ & -- & 33.7 & 2,050 & Do. \\
\hline 405008 & 790640 & Indiana & do. & PA06 & $\mathbf{P}$ & $11-25-80$ & $03-02-81$ & - & 34.9 & 1,185 & Do. \\
\hline 385754 & 792054 & Grant & wV & WV02 & $\mathbf{P}$ & $12-16-80$ & $03-04-81$ & -- & 10.7 & 3,980 & Woodland \\
\hline 421835 & 792408 & Chautaugua & NY & NY08 & $\mathbf{P}$ & $12-05-80$ & $03-02-81$ & 31.8 & 46.8 & 1,500 & Agricultural \& Woodland \\
\hline 392630 & 792704 & Garrett & MD & MD05 & $\mathrm{P}$ & $11-25-80$ & $03-02-81$ & 27.3 & 28.9 & 2,500 & Agricultural \\
\hline 392630 & 792704 & do. & do. & MD06 & $\mathbf{R}$ & $11-25-80$ & $03-02-81$ & 9.1 & 28.9 & 2,500 & Do. \\
\hline $\begin{array}{l}392630 \\
392630\end{array}$ & $\begin{array}{l}792704 \\
792704\end{array}$ & $\begin{array}{l}\text { do. } \\
\text { do. }\end{array}$ & $\begin{array}{l}\text { do. } \\
\text { do. }\end{array}$ & $\begin{array}{l}\text { MDO1 } \\
\text { MD02 }\end{array}$ & A & $\begin{array}{l}11-25-80 \\
12-23-80\end{array}$ & $\begin{array}{l}12-23-80 \\
02-03-81\end{array}$ & $\begin{array}{l}7.7 \\
6.4\end{array}$ & $\begin{array}{l}7.4 \\
9.8\end{array}$ & $\begin{array}{l}2,500 \\
2,500\end{array}$ & $\begin{array}{l}\text { Do. } \\
\text { Do. }\end{array}$ \\
\hline 392630 & 792704 & do. & do. & MD04 & c & $02-03-81$ & $02-09-81$ & 1.7 & 0.6 & 2,500 & Do. \\
\hline 392630 & 792704 & do. & do. & MD03 & D & $02-09-81$ & $03-02-81$ & 12.5 & 10.5 & 2,500 & Do. \\
\hline 384123 & 793230 & Pendleton & WV & WV05 & $\mathrm{P}$ & $12-16-80$ & $03-04-81$ & - & 20.2 & 4,640 & Woodland \\
\hline 385619 & 794316 & Rando $1 \mathrm{ph}$ & do. & WV03 & $\mathrm{P}$ & $12-15-80$ & $03-04-81$ & -- & 26.3 & 3,850 & Do. \\
\hline 410506 & 795327 & Butler & $\mathrm{PA}$ & PAO3 & $\mathbf{P}$ & $11-26-80$ & $03-02-81$ & - & 23.4 & 1,470 & Agricultural \\
\hline
\end{tabular}


TABLE 4. - Descriptions of bulk-precipitation-collection sites-Continued

\begin{tabular}{|c|c|c|c|c|c|c|c|c|c|c|c|}
\hline $\begin{array}{l}\text { Lat1- } \\
\text { tude }\end{array}$ & $\begin{array}{l}\text { Longi- } \\
\text { tude }\end{array}$ & County & State & $\begin{array}{l}\text { Sample } \\
\text { identi- } \\
\text { fication } \\
\text { number }\end{array}$ & $\begin{array}{c}\text { Sample } \\
\text { type }\end{array}$ & $\begin{array}{l}\text { Instal- } \\
\text { lation } \\
\text { date }\end{array}$ & $\begin{array}{l}\text { Collec- } \\
\text { tion } \\
\text { date }\end{array}$ & $\begin{array}{c}\text { Sample } \\
\text { volume } \\
\text { (liters) }\end{array}$ & $\begin{array}{l}\text { Estimated } \\
\text { sample } \\
\text { volume } \\
\text { (liters) }\end{array}$ & $\begin{array}{l}\text { Site } \\
\text { eleva- } \\
\text { tion } \\
\text { (feet) }\end{array}$ & Land use \\
\hline 384024 & 795348 & Randolph & wV & WV01 & $P$ & $12-17-80$ & $03-02-81$ & -- & 26.6 & 3,935 & Woodland \\
\hline 384024 & 795348 & do. & do. & WV06A & B & $12-17-80$ & $01-12-81$ & -- & 6.3 & 3,935 & Do. \\
\hline 384024 & & do. & do, & WV06B & C & $01-12-81$ & $02-02-81$ & -- & 3.6 & 3,935 & Do. \\
\hline 384024 & 795348 & do. & do. & WV06C & D & $02-02-81$ & $03-03-81$ & -- & 15.8 & 3,935 & Do. \\
\hline 382256 & 800503 & Pocahontas & do. & WV04 & $P$ & $12-17-80$ & $03-03-81$ & -- & 45.1 & 4,010 & Do. \\
\hline 394935 & 802100 & Greene & PA & PA05 & $\mathrm{P}$ & $11-20-80$ & $03-02-81$ & -- & 36.1 & 1,140 & Agricultural \\
\hline 414444 & 802715 & Crawford & do. & PA01A & $P$ & $11-26-80$ & $03-03-81$ & -- & 34.4 & 1,160 & Do. \\
\hline $\begin{array}{l}414444 \\
413446\end{array}$ & $\begin{array}{l}802715 \\
803206\end{array}$ & $\begin{array}{l}\text { do. } \\
\text { Ashtabula }\end{array}$ & $\begin{array}{l}\text { do. } \\
\text { OH }\end{array}$ & $\begin{array}{l}\text { PA01B } \\
\text { OI } 14\end{array}$ & $\begin{array}{l}\mathrm{R} \\
\mathrm{P}\end{array}$ & $\begin{array}{l}11-26-80 \\
12-01-80\end{array}$ & $\begin{array}{l}03-03-81 \\
03-02-81\end{array}$ & -- & $\begin{array}{l}34.4 \\
36.2\end{array}$ & $\begin{array}{l}1,160 \\
1,015\end{array}$ & $\begin{array}{l}\text { Do. } \\
\text { Do. }\end{array}$ \\
\hline 404800 & 805208 & Columbiana & do. & OI10 & $\mathbf{P}$ & $12-01-80$ & $03-03-81$ & -- & 28.5 & 1,140 & Do. \\
\hline 412839 & 805327 & Trumbu11 & do. & $0 I 13$ & $\mathrm{P}$ & $12-05-80$ & $03-02-81$ & - & 23.3 & 810 & Agricultural \& Wetlands \\
\hline 413629 & 805803 & As htabula & do. & OI 16 & $\mathrm{P}$ & $12-04-80$ & $03-02-81$ & -- & 29.1 & 1,055 & Agricultural \& Wetlands \\
\hline 415128 & 805822 & do. & do. & OI 18 & $\mathbf{P}$ & $12-04-80$ & $03-02-81$ & -- & 23.3 & 580 & Open water \\
\hline 415128 & 805822 & do. & do. & OI 19 & $\mathbf{R}$ & $12-04-80$ & $03-02-81$ & -- & 23.3 & 580 & Do. \\
\hline 415128 & 805822 & do. & do. & OI 17A & A & $12-04-80$ & $12-22-80$ & -- & 3.6 & 580 & Do. \\
\hline 415128 & 805822 & do. & do. & OI $17 \mathrm{~B}$ & B & $12-22-80$ & $01-12-81$ & -- & 5.0 & 580 & Do. \\
\hline 415128 & 805822 & do. & do. & OII7C & $\mathrm{c}$ & $01-12-81$ & $02-02-81$ & -- & 1.8 & 580 & Do. \\
\hline 415128 & 805822 & do. & do. & OI17D & D & $02-02-81$ & $03-02-81$ & -- & 13.1 & 580 & Do. \\
\hline 411233 & 810713 & Portage & do. & oI11 & $\mathbf{P}$ & $12-05-80$ & $03-03-81$ & -- & 29.2 & 1,120 & Agricultural \\
\hline 413256 & 811613 & Geauqa & do. & OI 15 & $\mathrm{P}$ & $12-02-80$ & $03-03-81$ & -- & 35.2 & 1,230 & Agricultural \& Rural residential \\
\hline 411530 & 815542 & Medina & do. & OI03 & $\mathbf{P}$ & $12-10-80$ & $03-02-81$ & -- & 23.3 & 795 & Do. \\
\hline 405152 & 815631 & Wayne & do. & $0 I 12$ & $\mathbf{P}$ & $12-05-80$ & $03-03-81$ & -- & 20.5 & 1,170 & Agricul tural \\
\hline 402351 & 821658 & Knox & do. & oI01 & $\mathbf{P}$ & $12-09-80$ & $03-02-81$ & -- & 26.3 & 885 & Do. \\
\hline 405743 & 824716 & Craw ford & do. & OI09 & $\mathbf{P}$ & $12-09-80$ & $03-02-81$ & - & 15.4 & 960 & Do. \\
\hline 405743 & 824716 & do. & do. & oI08 & $\mathbf{R}$ & $12-09-80$ & $03-02-81$ & -- & 15.4 & 960 & Do. \\
\hline 413232 & 824852 & Ot tawa & do. & OI05 & $\mathbf{P}$ & $12-10-80$ & $03-02-81$ & -- & 15.3 & 580 & Do. \\
\hline 403257 & 824906 & Morrow & do. & or06 & $\mathbf{P}$ & $12-09-80$ & $03-02-81$ & -- & 21.8 & 1,095 & Do. \\
\hline 425953 & 831058 & Lapeer & MI & MI07 & $\mathbf{P}$ & $11-26-80$ & $03-04-81$ & 7.7 & 26.8 & 920 & Do. \\
\hline 434549 & 831446 & Hur on & do. & MI 19 & $\mathbf{P}$ & $12-08-80$ & $03-03-81$ & 10.8 & 15.9 & 650 & Do. \\
\hline 403048 & 831545 & Marion & OH & or 07 & $\mathbf{P}$ & $12-11-80$ & $03-03-81$ & $\therefore$ & 15.0 & 945 & Do. \\
\hline 450829 & 833610 & Alpena & MI & MI 16 & P & $12-02-80$ & $03-03-81$ & 11.4 & 19.1 & 680 & Do. \\
\hline 443212 & 834322 & Alcona & do. & MI 17 & $\mathbf{P}$ & $11-24-80$ & $03-02-81$ & 19.4 & 22.0 & 930 & Do. \\
\hline 411254 & 834551 & Wood & $\mathrm{OH}$ & OI02 & $\mathbf{P}$ & $12-11-80$ & $03-03-81$ & -- & 14.7 & 700 & Do. \\
\hline 413838 & 842141 & Fulton & $\mathrm{OH}$ & 0104 & $\mathbf{P}$ & $12-10-80$ & $03-03-81$ & -- & 15.6 & 790 & Do. \\
\hline $\begin{array}{l}435243 \\
444230\end{array}$ & $\begin{array}{l}842818 \\
843026\end{array}$ & $\begin{array}{l}\text { Gladwin } \\
\text { Crawford }\end{array}$ & $\begin{array}{l}\text { MI } \\
\text { do. }\end{array}$ & $\begin{array}{l}\text { MI18 } \\
\text { MI08 }\end{array}$ & $\begin{array}{l}\mathbf{P} \\
\mathbf{P}\end{array}$ & $\begin{array}{l}11-26-80 \\
11-20-80\end{array}$ & $\begin{array}{l}03-03-81 \\
03-01-81\end{array}$ & $\begin{array}{l}14.4 \\
18.3\end{array}$ & $\begin{array}{l}18.9 \\
20.0\end{array}$ & $\begin{array}{r}720 \\
1,180\end{array}$ & $\begin{array}{l}\text { Agricultural \& Woodland } \\
\text { Do. }\end{array}$ \\
\hline $\begin{array}{l}444230 \\
444230 \\
444230\end{array}$ & $\begin{array}{l}843026 \\
843026 \\
843026\end{array}$ & $\begin{array}{l}\text { do. } \\
\text { do. } \\
\text { do. }\end{array}$ & $\begin{array}{l}\text { do. } \\
\text { do. } \\
\text { do. }\end{array}$ & $\begin{array}{l}\text { MIO9 } \\
\text { MI10A } \\
\text { MIIOB }\end{array}$ & $\begin{array}{l}\mathrm{R} \\
\mathrm{A} \\
\mathrm{B}\end{array}$ & $\begin{array}{l}11-20-80 \\
11-20-80 \\
12-22-80\end{array}$ & $\begin{array}{l}03-01-81 \\
12-22-80 \\
01-12-81\end{array}$ & $\begin{array}{r}12.5 \\
1.8 \\
2.9\end{array}$ & $\begin{array}{r}20.0 \\
6.8 \\
5.0\end{array}$ & $\begin{array}{l}1,180 \\
1,180 \\
1,180\end{array}$ & $\begin{array}{l}\text { Do. } \\
\text { Do. } \\
\text { Do. }\end{array}$ \\
\hline 444230 & 843026 & do. & do. & MI10C & $\mathrm{c}$ & $01-12-81$ & $02-02-81$ & 1.5 & 1.3 & 1,800 & Do. \\
\hline $\begin{array}{l}444230 \\
452226\end{array}$ & $\begin{array}{l}843026 \\
843054\end{array}$ & $\begin{array}{l}\text { do. } \\
\text { Cheboygan }\end{array}$ & $\begin{array}{l}\text { do. } \\
\text { do. }\end{array}$ & $\begin{array}{l}\text { MI10D } \\
\text { MI15 }\end{array}$ & $\begin{array}{l}\mathrm{D} \\
\mathrm{P}\end{array}$ & $\begin{array}{l}02-02-81 \\
11-26-80\end{array}$ & $\begin{array}{l}03-01-81 \\
03-03-81\end{array}$ & $\begin{array}{r}7.3 \\
20.6\end{array}$ & $\begin{array}{l}6.8 \\
18.5\end{array}$ & $\begin{array}{r}1,180 \\
750\end{array}$ & $\begin{array}{l}\text { Do. } \\
\text { Do. }\end{array}$ \\
\hline 423432 & 843523 & Ingham & do. & MIOL & $\mathbf{p}$ & $11-26-80$ & $03-03-81$ & 19.5 & 24.4 & 910 & Do. \\
\hline 423432 & 843523 & do. & do. & MI02 & $\mathbf{R}$ & $11-26-80$ & $03-03-81$ & 19.5 & 24.4 & 910 & Do. \\
\hline 423432 & 843523 & do. & do. & MI03A & A & $11-26-80$ & $12-22-80$ & - & 10.3 & 910 & Do. \\
\hline 423423 & 843523 & do. & do. & MI03B & B & $12-22-80$ & $01-12-81$ & -- & 5.7 & 910 & Do. \\
\hline 423423 & 843523 & do. & do. & MI03C & c & $01-12-81$ & $02-02-81$ & -- & 2.1 & 910 & Do. \\
\hline 423423 & 843523 & do. & do. & MI030 & D & $02-02-81$ & $03-08-81$ & -- & 6.2 & 910 & Do. \\
\hline
\end{tabular}


TABLE 4. - Descriptions of bulk-precipitation-collection sites-Continued

\begin{tabular}{|c|c|c|c|c|c|c|c|c|c|c|c|}
\hline $\begin{array}{l}\text { Lati- } \\
\text { tude } \\
\end{array}$ & $\begin{array}{l}\text { Long1- } \\
\text { tude }\end{array}$ & County & State & $\begin{array}{l}\text { Sample } \\
\text { identi- } \\
\text { fication } \\
\text { number }\end{array}$ & $\begin{array}{c}\text { Sample } \\
\text { type }\end{array}$ & $\begin{array}{l}\text { Instal- } \\
\text { lation } \\
\text { date }\end{array}$ & $\begin{array}{l}\text { Collec- } \\
\text { tion } \\
\text { date } \\
\end{array}$ & $\begin{array}{c}\text { Sample } \\
\text { volume } \\
\text { (11ters) } \\
\end{array}$ & $\begin{array}{l}\text { Estimated } \\
\text { sample } \\
\text { volume } \\
\text { (1iters) } \\
\end{array}$ & $\begin{array}{l}\text { Site } \\
\text { eleva- } \\
\text { tion } \\
\text { (feet) }\end{array}$ & Land use \\
\hline $\begin{array}{l}461222 \\
415148 \\
403408\end{array}$ & $\begin{array}{l}843548 \\
843622 \\
850054\end{array}$ & $\begin{array}{l}\text { Chippewa } \\
\text { Hillsdale } \\
\text { Jay }\end{array}$ & $\begin{array}{l}\text { MI } \\
\text { do. } \\
\text { IN }\end{array}$ & $\begin{array}{l}\text { MI28 } \\
\text { MI04 } \\
\text { INO6 }\end{array}$ & $\begin{array}{l}\mathrm{P} \\
\mathrm{P} \\
\mathrm{P}\end{array}$ & $\begin{array}{l}12-02-80 \\
11-25-80 \\
12-04-80\end{array}$ & $\begin{array}{l}03-03-81 \\
03-03-81 \\
03-05-81\end{array}$ & $\begin{array}{r}8.2 \\
20.0 \\
11.9\end{array}$ & $\begin{array}{l}19.5 \\
28.5 \\
18.0\end{array}$ & $\begin{array}{r}660 \\
1,150 \\
843\end{array}$ & $\begin{array}{l}\text { Agricultural } \\
\text { Do. } \\
\text { Agricultural \& Woodland }\end{array}$ \\
\hline 394331 & 851155 & Fayette & do. & INO9 & $\mathbf{P}$ & $11-21-80$ & $03-09-81$ & 16.8 & 22.6 & 1,025 & Do. \\
\hline $\begin{array}{l}390701 \\
411958\end{array}$ & $\begin{array}{l}851322 \\
852235\end{array}$ & $\begin{array}{l}\text { Ripley } \\
\text { Noble }\end{array}$ & $\begin{array}{l}\text { do. } \\
\text { do. }\end{array}$ & $\begin{array}{l}\text { IN12 } \\
\text { IN03 }\end{array}$ & $\begin{array}{l}\mathrm{P} \\
\mathrm{P}\end{array}$ & $\begin{array}{l}11-20-80 \\
11-26-80\end{array}$ & $\begin{array}{l}03-09-81 \\
03-04-81\end{array}$ & $\begin{array}{l}25.7 \\
13.8\end{array}$ & $\begin{array}{l}25.4 \\
25.8\end{array}$ & $\begin{array}{l}970 \\
960\end{array}$ & $\begin{array}{l}\text { Do. } \\
\text { Woodland \& Agricultural }\end{array}$ \\
\hline 411958 & 852235 & do. & do. & IN15A & A & $11-26-80$ & $12-22-80$ & 5.6 & 7.6 & 960 & Do. \\
\hline $\begin{array}{l}411958 \\
411958\end{array}$ & $\begin{array}{l}852235 \\
852235\end{array}$ & $\begin{array}{l}\text { do. } \\
\text { do. }\end{array}$ & $\begin{array}{l}\text { do. } \\
\text { do. }\end{array}$ & $\begin{array}{l}\text { IN1 5B } \\
\text { IN15C }\end{array}$ & $\begin{array}{l}\text { B } \\
\text { C }\end{array}$ & $\begin{array}{l}12-22-80 \\
01-12-81\end{array}$ & $\begin{array}{l}01-12-81 \\
02-09-81\end{array}$ & $\begin{array}{l}1.4 \\
3.2\end{array}$ & $\begin{array}{l}7.9 \\
3.4\end{array}$ & $\begin{array}{l}960 \\
960\end{array}$ & $\begin{array}{l}\text { Do. } \\
\text { Do. }\end{array}$ \\
\hline 411958 & 852235 & do. & do. & IN15D & D & $02-09-81$ & $03-04-81$ & 7.3 & 6.8 & 960 & Do. \\
\hline 443818 & 853110 & Grand travers & MI & MI 14 & $\mathbf{P}$ & $11-25-80$ & $03-04-81$ & 29.8 & 26.8 & 760 & Woodland \\
\hline 462459 & 853429 & Luce & do. & MI 30 & $\mathrm{p}$ & $12-02-80$ & $03-05-81$ & 15.1 & 37.8 & 810 & Do. \\
\hline 462459 & 853429 & do. & do. & MI 31 & s & - & $03-05-81$ & - & -- & 810 & Do. \\
\hline $\begin{array}{l}432610 \\
422121\end{array}$ & $\begin{array}{l}854000 \\
854916\end{array}$ & $\begin{array}{l}\text { Newaygo } \\
\text { Van Buren }\end{array}$ & $\begin{array}{l}\text { do. } \\
\text { do. }\end{array}$ & $\begin{array}{l}\text { MI12 } \\
\text { MI06 }\end{array}$ & $\begin{array}{l}\mathrm{P} \\
\mathrm{P}\end{array}$ & $\begin{array}{l}12-04-80 \\
11-24-80\end{array}$ & $\begin{array}{l}03-03-81 \\
03-02-81\end{array}$ & $\begin{array}{l}15.4 \\
24.5\end{array}$ & $\begin{array}{l}23.3 \\
37.4\end{array}$ & $\begin{array}{l}730 \\
800\end{array}$ & $\begin{array}{l}\text { Agricultural } \\
\text { Woodland \& Agricultural }\end{array}$ \\
\hline 435640 & 855103 & Lake & do. & MI13 & P & $11-25-80$ & $03-03-81$ & 20.9 & 28.2 & 900 & Do. \\
\hline $\begin{array}{l}411233 \\
382805\end{array}$ & $\begin{array}{l}855616 \\
860334\end{array}$ & $\begin{array}{l}\text { Kosciusko } \\
\text { Washington }\end{array}$ & $\begin{array}{l}\text { IN } \\
\text { do. }\end{array}$ & $\begin{array}{l}\text { IN02 } \\
\text { IN14 }\end{array}$ & $\begin{array}{l}\mathrm{P} \\
\mathrm{P}\end{array}$ & $\begin{array}{l}11-25-80 \\
11-18-80\end{array}$ & $\begin{array}{l}03-04-81 \\
03-11-81\end{array}$ & $\begin{array}{l}19.2 \\
23.9\end{array}$ & $\begin{array}{l}24.0 \\
28.9\end{array}$ & $\begin{array}{l}835 \\
760\end{array}$ & $\begin{array}{l}\text { Agricultural \& Woodland } \\
\text { Do. }\end{array}$ \\
\hline 390744 & 860641 & Brown & do. & IN1.1 & $\mathrm{P}$ & $11-20-80$ & $03-10-81$ & 27.2 & 22.3 & 625 & Woodland \\
\hline 400126 & 861855 & Boone & do. & INO8 & $\mathbf{P}$ & $11-17-80$ & $03-08-81$ & 11.3 & 23.2 & 935 & Agricul tural \\
\hline 400126 & 861855 & do. & do. & IN16A & A & $11-17-80$ & $12-22-80$ & 9.1 & 6.5 & 935 & Do. \\
\hline 400126 & 861855 & do. & do. & IN16B & B & $12-22-80$ & $01-12-81$ & 4.6 & 2.6 & 935 & Do. \\
\hline $\begin{array}{l}400126 \\
400126\end{array}$ & $\begin{array}{l}861855 \\
861855\end{array}$ & do. & do. & IN16C & c & $01-12-81$ & $\begin{array}{l}02-02-81 \\
03-08-81\end{array}$ & $\begin{array}{l}3.2 \\
9.0\end{array}$ & 1.5 & 935 & Do. \\
\hline 400126 & $\begin{array}{l}861855 \\
861914\end{array}$ & $\begin{array}{l}\text { do. } \\
\text { Cass }\end{array}$ & do. & IN16D & $\begin{array}{l}\mathrm{D} \\
\mathrm{P}\end{array}$ & $\begin{array}{l}02-02-81 \\
12-04-80\end{array}$ & $\begin{array}{l}03-08-81 \\
03-07-81\end{array}$ & $\begin{array}{r}9.0 \\
14.3\end{array}$ & 12.6 & 935 & Do. \\
\hline 403707 & 861914 & Cass & do. & INOS & P & $\begin{array}{l}12-04-80 \\
11-24-80\end{array}$ & $03-07-81$ & $14 \cdot 3$ & $\begin{array}{l}15.7 \\
28.5\end{array}$ & $\begin{array}{l}750 \\
730\end{array}$ & Do. \\
\hline $\begin{array}{l}420159 \\
461026\end{array}$ & $\begin{array}{l}862009 \\
862518\end{array}$ & $\begin{array}{l}\text { Berrien } \\
\text { Schoolcraft }\end{array}$ & $\begin{array}{l}\text { MI } \\
\text { do. }\end{array}$ & $\begin{array}{l}\text { MI05 } \\
\text { MI29 }\end{array}$ & $\begin{array}{l}\mathrm{P} \\
\mathrm{P}\end{array}$ & $\begin{array}{l}11-24-80 \\
12-03-80\end{array}$ & $\begin{array}{l}03-02-81 \\
03-05-81\end{array}$ & $\begin{array}{l}20.4 \\
22.0\end{array}$ & $\begin{array}{l}28.5 \\
30.1\end{array}$ & $\begin{array}{l}730 \\
710\end{array}$ & $\begin{array}{c}\text { Do. } \\
\text { Woodland }\end{array}$ \\
\hline 461026 & 862518 & $\begin{array}{l}\text { Schoolcraft } \\
\text { La porte }\end{array}$ & $\begin{array}{l}\text { do. } \\
\text { IN }\end{array}$ & $\begin{array}{r}\text { MI29 } \\
\text { INO1 }\end{array}$ & & $\begin{array}{l}12-03-80 \\
11-24-80\end{array}$ & $03-05-81$ & 22.0 & 30.1 & $\begin{array}{l}710 \\
670\end{array}$ & \\
\hline 411947 & 864703 & La porte & IN & INOI & $P$ & $11-24-80$ & $03-04-81$ & 18.7 & 21.3 & 670 & Agricultural \\
\hline 404859 & $\begin{array}{l}865014 \\
870213\end{array}$ & $\begin{array}{l}\text { White } \\
\text { Greene }\end{array}$ & $\begin{array}{l}\text { do. } \\
\text { do. }\end{array}$ & $\begin{array}{l}\text { INO4 } \\
\text { IN10 }\end{array}$ & $\begin{array}{l}\mathbf{P} \\
\mathbf{P}\end{array}$ & $\begin{array}{l}12-03-80 \\
11-20-80\end{array}$ & $03-07-81$ & 13.6 & $\begin{array}{l}20.0 \\
24.3\end{array}$ & $\begin{array}{l}885 \\
515\end{array}$ & Agricultural \& Woodland \\
\hline 390929 & 870213 & Greene & do. & IN10 & & $11-20-80$ & $03-10-81$ & 31.1 & 24.3 & 515 & Do. \\
\hline 382221 & 870324 & Dubois & do. & IN 13 & $\mathrm{p}$ & $11-19-80$ & $03-11-81$ & 28.3 & 24.3 & 495 & Do. \\
\hline $\begin{array}{l}395610 \\
454300\end{array}$ & $\begin{array}{l}870605 \\
871115\end{array}$ & $\begin{array}{l}\text { Parke } \\
\text { Delta }\end{array}$ & $\begin{array}{l}\text { do. } \\
\text { MI }\end{array}$ & $\begin{array}{l}\text { INO } 7 \\
\text { MI20 }\end{array}$ & $\begin{array}{l}\mathbf{P} \\
\mathbf{P}\end{array}$ & $\begin{array}{l}12-03-80 \\
12-01-80\end{array}$ & $\begin{array}{l}03-12-81 \\
03-04-81\end{array}$ & $\begin{array}{l}21.0 \\
11.0\end{array}$ & $\begin{array}{l}20.5 \\
12.1\end{array}$ & $\begin{array}{l}720 \\
670\end{array}$ & $\begin{array}{l}\text { Woodland } \\
\text { Woodland \& Agricultural }\end{array}$ \\
\hline 454300 & 871115 & do. & do. & MI21 & R & $12-01-80$ & $03-04-81$ & 9.9 & 12.1 & 670 & Do. \\
\hline 454300 & 871115 & do. & do. & MI22A & A & $12-01-80$ & $12-22-80$ & 2.5 & 3.0 & 670 & Do. \\
\hline 454300 & 871115 & do. & do. & MI22B & B & $12-22-80$ & $01-12-81$ & 2.0 & 1.8 & 670 & Do. \\
\hline 454300 & 871115 & do. & do. & MI $22 \mathrm{C}$ & c & $01-12-81$ & $02-02-81$ & 1.4 & 2.5 & 670 & Do. \\
\hline 454300 & 871115 & do. & do. & MI22D & D & $02-02-81$ & $03-04-81$ & 6.1 & 4.8 & 670 & Do. \\
\hline 441908 & 873449 & Kewaunee & WI & WI 28 & $\mathbf{P}$ & $12-04-80$ & $03-04-81$ & 9.9 & 17.1 & 755 & Agricultural \\
\hline 463323 & 874128 & Marquette & MI & MI26 & $\mathbf{P}$ & $11-26-80$ & $03-05-81$ & 17.2 & 18.7 & 1,440 & Woodland \\
\hline 460121 & 875022 & Dickinson & do. & MI27 & $\mathrm{P}$ & $11-26-80$ & $03-04-81$ & 13.5 & 16.6 & 1,120 & Woodland \& Agricultural \\
\hline 403312 & 875823 & Iroquols & IL & IL10 & $\mathbf{P}$ & $12-02-80$ & $03-01-81$ & 13.5 & 19.1 & 680 & Agricultural \\
\hline 400002 & 875827 & Champatgn & do. & IL15 & $\mathbf{P}$ & $12-01-80$ & $03-01-81$ & 14.7 & 15.1 & 685 & Do. \\
\hline 410833 & 875835 & Kankakee & do. & IL09 & $\mathbf{p}$ & $11-19-80$ & $03-01-81$ & 17.1 & 20.2 & 644 & Do. \\
\hline 414225 & 875920 & Cook & do. & & $\mathbf{P}$ & $12-01-80$ & - & - & - & -- & Heavy industrial \\
\hline 384909 & 875931 & Richland & do. & IL20 & $\mathbf{P}$ & $11-25-80$ & $03-01-81$ & 16.8 & 18.9 & 480 & Agricul tural \\
\hline $\begin{array}{l}392743 \\
422708\end{array}$ & 880145 & Coles & do. & IL16 & $\mathbf{P}$ & $11-25-80$ & $03-01-81$ & 8.5 & 20.6 & 770 & Do. \\
\hline 422708 & 880228 & Lake & do. & & $\mathbf{P}$ & $11-27-80$ & -- & -- & - & -- & Do. \\
\hline
\end{tabular}


TABLE 4. - Descriptions of bulk-precipitation-collection sites-Continued

\begin{tabular}{|c|c|c|c|c|c|c|c|c|c|c|c|}
\hline $\begin{array}{l}\text { Lati- } \\
\text { tude }\end{array}$ & $\begin{array}{l}\text { Long 1- } \\
\text { tude }\end{array}$ & County & State & $\begin{array}{l}\text { Sample } \\
\text { identi- } \\
\text { fication } \\
\text { number }\end{array}$ & $\begin{array}{c}\text { Sample } \\
\text { type }\end{array}$ & $\begin{array}{l}\text { Instal- } \\
\text { lation } \\
\text { date }\end{array}$ & $\begin{array}{l}\text { Collec- } \\
\text { tion } \\
\text { date } \\
\end{array}$ & $\begin{array}{c}\text { Sample } \\
\text { volune } \\
\text { (11ters) }\end{array}$ & $\begin{array}{l}\text { Estimated } \\
\text { sample } \\
\text { volume } \\
\text { (1iters) } \\
\end{array}$ & $\begin{array}{l}\text { Site } \\
\text { eleva- } \\
\text { tion } \\
\text { (feet) }\end{array}$ & Land use \\
\hline 382015 & 880455 & Edwards & IL & IL21 & $P$ & $11-28-80$ & $03-01-81$ & 13.2 & 22.1 & 408 & Agricultural \\
\hline 433434 & 881116 & Fond Du Lac & WI & WI 27 & $\mathrm{P}$ & $12-04-80$ & $03-04-81$ & 0.5 & 13.9 & 990 & Wetlands \\
\hline 444949 & 881831 & Shawano & do. & WI09 & $\mathrm{P}$ & $12-02-80$ & $03-02-81$ & 7.8 & 16.3 & 825 & Agricultural \\
\hline 454530 & 882748 & Florence & do. & WI 12 & P & $12-02-80$ & $03-02-81$ & 8.6 & 16.3 & 1,450 & None \\
\hline 463453 & 883412 & Baraga & do. & MI 25 & $\mathrm{P}$ & $11-25-80$ & $03-04-81$ & 18.6 & 24.8 & 1,270 & Agricultural \& Woodland \\
\hline 471338 & 883744 & Houghton & do. & MI 24 & $\mathrm{P}$ & $11-25-80$ & $03-05-81$ & 15.4 & 23.1 & 630 & Do. \\
\hline 424430 & 883746 & Walworth & do. & WI 26 & P & $12-03-80$ & $03-04-81$ & 16.2 & 16.5 & 910 & Wetland \\
\hline 382138 & 884854 & Jef ferson & IL & IL22 & $\mathbf{P}$ & $11-28-80$ & $03-01-81$ & -- & 17.8 & 545 & Agricultura1 \\
\hline 38523232 & 885401 & Fayette & do. & IL1.9 & $\mathbf{P}$ & $11-25-80$ & $03-01-81$ & 11.7 & 19.1 & 595 & Do. \\
\hline 400400 & 885450 & Macon & do. & & $\mathbf{P}$ & $12-04-80$ & -- & - & -- & -- & Do. \\
\hline 414505 & 885540 & Deka 1b & do. & & $\mathbf{P}$ & $11-28-80$ & -- & -- & -- & - & Do. \\
\hline 411230 & 885551 & Lasalle & do. & IL08 & $\mathrm{P}$ & $11-19-80$ & $03-01-81$ & 17.0 & 27.2 & 690 & Do. \\
\hline 403412 & 885628 & Mclean & do. & IL11 & $\mathbf{P}$ & $12-02-80$ & $03-01-81$ & 13.5 & 16.8 & 780 & Do. \\
\hline $\begin{array}{l}392535 \\
421842\end{array}$ & $\begin{array}{l}885631 \\
885912\end{array}$ & $\begin{array}{l}\text { Shelby } \\
\text { Winnebago }\end{array}$ & $\begin{array}{l}\text { do. } \\
\text { do. }\end{array}$ & IL17 & $\begin{array}{l}\mathrm{P} \\
\mathrm{P}\end{array}$ & $\begin{array}{l}11-25-80 \\
11-26-80\end{array}$ & $03-01-81$ & 13.2 & 22.2 & 650 & $\begin{array}{l}\text { Agricultural \& Woodland } \\
\text { Agricultural }\end{array}$ \\
\hline 463339 & 891936 & Ontonagon & MI & MI23 & $\mathrm{P}$ & $11-24-80$ & $03-04-81$ & 11.6 & 38.3 & 1,260 & Agricultural \& Woodland \\
\hline $\begin{array}{l}443949 \\
460307\end{array}$ & $\begin{array}{l}892020 \\
893912\end{array}$ & $\begin{array}{l}\text { Portage } \\
\text { Vilas }\end{array}$ & $\begin{array}{l}\text { WI } \\
\text { do. }\end{array}$ & $\begin{array}{l}\text { WI08 } \\
\text { WI14 }\end{array}$ & $\begin{array}{l}\mathbf{P} \\
\mathrm{P}\end{array}$ & $\begin{array}{l}12-03-80 \\
11-25-80\end{array}$ & $\begin{array}{l}03-02-81 \\
03-02-81\end{array}$ & $\begin{array}{r}13.7 \\
5.0\end{array}$ & $\begin{array}{l}16.5 \\
11.9\end{array}$ & $\begin{array}{l}1,190 \\
1,650\end{array}$ & $\begin{array}{l}\text { Do. } \\
\text { Woodland }\end{array}$ \\
\hline 460307 & 893912 & do. & do. & WI 15 & $\mathrm{R}$ & $11-25-80$ & $03-02-81$ & 10.8 & 11.9 & 1,650 & Do. \\
\hline $\begin{array}{l}460307 \\
460307\end{array}$ & $\begin{array}{l}893912 \\
893912\end{array}$ & $\begin{array}{l}\text { do. } \\
\text { do. }\end{array}$ & $\begin{array}{l}\text { do. } \\
\text { do. }\end{array}$ & $\begin{array}{l}\text { WI 16A } \\
\text { WI16B }\end{array}$ & $\begin{array}{l}\text { A } \\
\text { B }\end{array}$ & $\begin{array}{l}11-25-80 \\
12-22-80\end{array}$ & $\begin{array}{l}12-22-80 \\
01-12-81\end{array}$ & $\begin{array}{l}2.4 \\
2.7\end{array}$ & $\begin{array}{l}2.6 \\
2.5\end{array}$ & $\begin{array}{l}1,650 \\
1,650\end{array}$ & $\begin{array}{l}\text { Do. } \\
\text { Do. }\end{array}$ \\
\hline 460307 & 893912 & do. & do. & WI16C & c & $01-12-81$ & $02-02-81$ & 1.5 & 1.2 & 1,650 & Do. \\
\hline 460307 & 893912 & do. & do. & WI 160 & D & $02-02-81$ & $03-02-81$ & 4.3 & 7.4 & 1,650 & Do. \\
\hline 460307 & 893912 & do. & do. & WI17 & $\mathrm{s}$ & $11-25-80$ & $03-02-81$ & 4.9 & -- & 1,650 & Do. \\
\hline 455909 & 894058 & do. & do. & WI13 & P & $12-01-80$ & $03-02-81$ & 6.0 & 11.7 & 1,630 & Do. \\
\hline 432557 & 894358 & Sank & do. & WI01 & $\mathrm{P}$ & $12-03-80$ & $03-02-81$ & 15.1 & 8.8 & 950 & Do. \\
\hline 432557 & 894358 & do. & do. & WI02 & $\mathbf{R}$ & $12-03-80$ & $03-02-81$ & 15.0 & 8.8 & 950 & Do. \\
\hline 441257 & 894502 & Adams & do. & WI07 & $\mathbf{P}$ & $12-03-80$ & $03-02-81$ & 11.0 & 13.3 & 1,030 & Do. \\
\hline 403510 & 894826 & Peoria & IL & & $\mathrm{P}$ & $12-02-80$ & -- & - & - & - & Agricultural \\
\hline 415006 & 894827 & Whiteside & do. & & P & $11-28-80$ & - & - & -- & - & Do. \\
\hline 400335 & 895314 & Menard & do. & & P & $12-02-80$ & -- & - & -- & - & Do. \\
\hline 410816 & 895452 & Stark & do. & & $\mathrm{P}$ & $12-01-80$ & -- & -- & -- & - & Do. \\
\hline 435732 & 895659 & Green Lake & WI & WI06 & $\mathbf{P}$ & $12-05-80$ & $02-26-81$ & 11.2 & 7.9 & 760 & Do. \\
\hline 392325 & 895836 & Macoupin & IL & ILl8 & P & $11-26-80$ & $03-01-81$ & 11.6 & 17.1 & 610 & Do. \\
\hline 422508 & 895840 & Jo Daviess & do. & & P & $12-01-80$ & - & $\rightarrow$ & - & - & Do. \\
\hline 452802 & 895846 & Lincoln & WI & WI11 & P & $12-03-80$ & $03-03-81$ & 7.0 & 11.5 & 1,485 & Do. \\
\hline 460743 & 901111 & Iron & do. & WI 18 & $\mathbf{P}$ & $12-01-80$ & $03-02-81$ & 5.2 & 12.9 & 1,575 & Woodland \\
\hline $\begin{array}{l}445528 \\
480235\end{array}$ & $\begin{array}{l}901228 \\
902842\end{array}$ & $\begin{array}{l}\text { Marathon } \\
\text { Cook }\end{array}$ & $\begin{array}{l}\text { do. } \\
\text { MN }\end{array}$ & $\begin{array}{l}\text { WI10 } \\
\text { MN21 }\end{array}$ & $\begin{array}{l}\mathrm{P} \\
\mathrm{P}\end{array}$ & $\begin{array}{l}12-02-80 \\
12-09-80\end{array}$ & $\begin{array}{l}03-02-81 \\
03-10-81\end{array}$ & 8.1 & $\begin{array}{l}14.6 \\
13.0\end{array}$ & $\begin{array}{l}1,350 \\
1,889\end{array}$ & $\begin{array}{l}\text { Agricultural } \\
\text { Woodland }\end{array}$ \\
\hline 424413 & 903834 & Grant & WI & WI04 & $\mathbf{P}$ & $12-03-80$ & $03-02-81$ & 11.3 & 12.9 & 700 & Agricul tural \\
\hline $\begin{array}{l}433418 \\
465426\end{array}$ & $\begin{array}{l}903853 \\
905351\end{array}$ & $\begin{array}{l}\text { Vernon } \\
\text { Bayfield }\end{array}$ & $\begin{array}{l}\text { do. } \\
\text { do: }\end{array}$ & $\begin{array}{l}\text { WI05 } \\
\text { WI25 }\end{array}$ & $\begin{array}{l}\mathrm{P} \\
\mathrm{P}\end{array}$ & $\begin{array}{l}12-04-80 \\
12-02-80\end{array}$ & $\begin{array}{l}03-03-81 \\
02-23-81\end{array}$ & $\begin{array}{r}6.6 \\
16.5\end{array}$ & $\begin{array}{r}9.9 \\
16.0\end{array}$ & $\begin{array}{l}800 \\
895\end{array}$ & $\begin{array}{l}\text { Do. } \\
\text { Woodland \& Agricultural }\end{array}$ \\
\hline 452011 & 905814 & Rusk & do. & WI 22 & $\mathrm{p}$ & $12-01-80$ & $03-03-81$ & - & 13.9 & 1,145 & Agricultural \\
\hline $\begin{array}{l}444942 \\
440715\end{array}$ & $\begin{array}{l}905857 \\
912140\end{array}$ & $\begin{array}{l}\text { Eau Claire } \\
\text { Trempealeau }\end{array}$ & $\begin{array}{l}\text { do. } \\
\text { do. }\end{array}$ & $\begin{array}{l}\text { WI } 20 \\
\text { WI } 19\end{array}$ & $\begin{array}{l}\mathrm{P} \\
\mathrm{P}\end{array}$ & $\begin{array}{l}12-01-80 \\
12-03-80\end{array}$ & $\begin{array}{l}03-02-81 \\
03-02-81\end{array}$ & $\begin{array}{l}9.1 \\
7.9\end{array}$ & $\begin{array}{l}11.5 \\
12.9\end{array}$ & $\begin{array}{l}1,045 \\
770\end{array}$ & $\begin{array}{l}\text { Do. } \\
\text { Agricultural \& Woodland }\end{array}$ \\
\hline 475800 & 912905 & Lake & MN & MN20 & $\mathrm{P}$ & $12-02-80$ & $03-10-81$ & - & 13.5 & 1,660 & Woodland \\
\hline $\begin{array}{l}463207 \\
454920\end{array}$ & $\begin{array}{l}913454 \\
915229\end{array}$ & $\begin{array}{l}\text { Douglas } \\
\text { Washburn }\end{array}$ & $\begin{array}{l}\text { WI } \\
\text { do. }\end{array}$ & $\begin{array}{l}\text { WI } 24 \\
\text { WI } 23\end{array}$ & $\begin{array}{l}P \\
P\end{array}$ & $\begin{array}{l}12-02-80 \\
11-26-80\end{array}$ & $\begin{array}{l}02-24-81 \\
02-26-81\end{array}$ & $\begin{array}{r}10.8 \\
6.6\end{array}$ & $\begin{array}{r}12.8 \\
8.5\end{array}$ & $\begin{array}{r}970 \\
1,090\end{array}$ & $\begin{array}{l}\text { Do. } \\
\text { Agricultural }\end{array}$ \\
\hline
\end{tabular}


TABLE 4.-Descriptions of bulk-precipitation-collection sites-Continued

\begin{tabular}{|c|c|c|c|c|c|c|c|c|c|c|c|}
\hline $\begin{array}{l}\text { Lati- } \\
\text { tude } \\
\end{array}$ & $\begin{array}{l}\text { Long } 1- \\
\text { tude }\end{array}$ & County & State & $\begin{array}{l}\text { Sample } \\
\text { identi- } \\
\text { fication } \\
\text { number }\end{array}$ & $\begin{array}{c}\text { Sample } \\
\text { type }\end{array}$ & $\begin{array}{l}\text { Instal- } \\
\text { lation } \\
\text { date }\end{array}$ & $\begin{array}{l}\text { Collec- } \\
\text { t1on } \\
\text { date }\end{array}$ & $\begin{array}{c}\text { Sample } \\
\text { volume } \\
\text { (11ters) }\end{array}$ & $\begin{array}{l}\text { Estimated } \\
\text { sample } \\
\text { volume } \\
\text { (liters) } \\
\end{array}$ & $\begin{array}{l}\text { Site } \\
\text { eleva- } \\
\text { tion } \\
\text { (feet) }\end{array}$ & Land use \\
\hline 450320 & 915606 & Dunn & WI & WI 21 & $\mathbf{P}$ & $12-01-80$ & $03-02-81$ & -- & 14.3 & 930 & Agricultural \\
\hline 470642 & 915911 & St. Louis & MN & MN12 & P & $12-03-80$ & $03-10-81$ & 10.3 & 9.9 & 1,429 & Do. \\
\hline 463113 & 923303 & Carlton & do. & MN1 1 & $\mathbf{P}$ & $12-03-80$ & $03-10-81$ & 5.8 & 9.3 & 1,097 & Woodland \\
\hline 455531 & 931726 & Kanabec & do. & MNO5 & $\mathbf{P}$ & $11-28-80$ & $03-09-81$ & 7.2 & 8.4 & 1,037 & Field \\
\hline $\begin{array}{l}472807 \\
472807\end{array}$ & $\begin{array}{l}933153 \\
933153\end{array}$ & $\begin{array}{r}\text { Itasca } \\
\text { do. }\end{array}$ & $\begin{array}{l}\text { do. } \\
\text { do. }\end{array}$ & $\begin{array}{l}\text { MN26 } \\
\text { MN25 }\end{array}$ & $\begin{array}{l}\mathbf{P} \\
\mathbf{R}\end{array}$ & $\begin{array}{l}11-25-80 \\
11-25-80\end{array}$ & $\begin{array}{l}03-02-81 \\
03-02-81\end{array}$ & $=$ & $\begin{array}{l}5.4 \\
5.4\end{array}$ & $\begin{array}{l}1,400 \\
1,400\end{array}$ & $\begin{array}{c}\text { Woodland } \\
\text { Do. }\end{array}$ \\
\hline 472807 & 933153 & do. & do. & MN13A & $\mathbf{A}$ & $11-25-80$ & $12-22-80$ & -- & 2.2 & 1,400 & Do. \\
\hline $\begin{array}{l}472807 \\
472807\end{array}$ & $\begin{array}{l}933153 \\
933153\end{array}$ & $\begin{array}{l}\text { do. } \\
\text { do. }\end{array}$ & $\begin{array}{l}\text { do. } \\
\text { do. }\end{array}$ & $\begin{array}{l}\text { MN13B } \\
\text { MN13C }\end{array}$ & $\begin{array}{l}\text { C } \\
\text { D }\end{array}$ & $\begin{array}{l}01-12-81 \\
02-02-81\end{array}$ & $\begin{array}{l}02-02-81 \\
03-02-81\end{array}$ & $=-$ & $\begin{array}{l}1.2 \\
1.5\end{array}$ & $\begin{array}{l}1,400 \\
1,400\end{array}$ & $\begin{array}{l}\text { Do. } \\
\text { Do. }\end{array}$ \\
\hline 472807 & 933153 & do. & do. & MN27 & $\mathrm{s}$ & - & $03-02-81$ & -- & -- & 1,400 & Do. \\
\hline $\begin{array}{l}444205 \\
444205\end{array}$ & $\begin{array}{l}933927 \\
933927\end{array}$ & $\begin{array}{c}\text { Carver } \\
\text { do. }\end{array}$ & $\begin{array}{l}\text { do. } \\
\text { do. }\end{array}$ & $\begin{array}{l}\text { MN04 } \\
\text { MN28 }\end{array}$ & $\begin{array}{l}\mathbf{P} \\
\mathbf{R}\end{array}$ & $\begin{array}{l}11-24-80 \\
11-24-80\end{array}$ & $\begin{array}{l}03-09-81 \\
03-09-81\end{array}$ & $\begin{array}{l}7.2 \\
7.2\end{array}$ & $\begin{array}{l}8.4 \\
8.4\end{array}$ & $\begin{array}{l}712 \\
712\end{array}$ & $\begin{array}{l}\text { Agricultural \& Woodland } \\
\text { Do. }\end{array}$ \\
\hline 483622 & 935147 & Koochiching & do. & MN22 & $\mathrm{p}$ & $\begin{array}{l}11-24-80 \\
11-25-80\end{array}$ & $\begin{array}{l}03-09-81 \\
02-24-81\end{array}$ & $\begin{array}{l}7.2 \\
--\end{array}$ & $\begin{array}{l}8.4 \\
4.8\end{array}$ & $\begin{array}{r}712 \\
1,127\end{array}$ & $\begin{array}{l}\text { Do. } \\
\text { Agricul tural }\end{array}$ \\
\hline 474607 & 935156 & Itasca & do. & MN19 & $\mathrm{P}$ & $11-26-80$ & $03-02-81$ & -- & 5.4 & $\begin{array}{l}1,121 \\
1,333\end{array}$ & Agricultural \\
\hline 463254 & 941431 & Crow W1ng & do. & MN10 & $\mathbf{P}$ & $11-26-80$ & $03-10-81$ & 6.3 & 8.4 & $\begin{array}{l}1,333 \\
1,247\end{array}$ & Do. \\
\hline 470251 & 941526 & Cass & do. & MN14 & $\mathbf{P}$ & $11-26-80$ & $03-02-81$ & -- & 3.6 & $\begin{array}{l}1,241 \\
1,368\end{array}$ & Do. \\
\hline 451038 & 941800 & Meeker & do. & MNO3 & $\mathbf{p}$ & $11-21-80$ & $03-09-81$ & 3.4 & 9.8 & 1,020 & $\begin{array}{l}\text { Do. } \\
\text { Do. }\end{array}$ \\
\hline 455142 & 942130 & Morrison & do. & MN06 & $\mathbf{P}$ & $11-26-80$ & $03-11-81$ & 5.9 & 7.9 & 1,090 & Woodland \\
\hline 484307 & 945355 & Lake & do. & MN23 & $\mathbf{P}$ & $11-25-80$ & $02-24-81$ & - & 3.2 & 1,090 & Agricultural \& Woodland \\
\hline 472610 & 951548 & Clearwater & do. & MN15 & $\mathbf{P}$ & $11-24-80$ & $02-26-81$ & -- & 4.3 & 1,540 & Do. \\
\hline 463108 & 951654 & Otter Tall & do. & MN09 & $\mathbf{P}$ & $11-24-80$ & $02-25-81$ & 1.3 & 3.4 & 1,391 & Agricultural \\
\hline 451253 & 951934 & Swift & do. & MNO2 & $\mathbf{P}$ & $11-21-80$ & $02-25-81$ & 2.2 & 5.9 & 1,100 & Do. \\
\hline 481545 & 952418 & Beltrami & do. & MN18 & $\mathbf{P}$ & $11-24-80$ & $02-26-81$ & -- & 2.4 & 1,214 & Do. \\
\hline 453954 & 952633 & Popoe & do. & MN07 & $\mathbf{P}$ & $11-24-80$ & $02-25-81$ & 2.4 & 3.3 & 1,254 & Do. \\
\hline 453021 & 961234 & Stevens & do. & MNOI & $\mathbf{P}$ & $11-21-80$ & $02-25-81$ & 1.0 & 5.0 & 1,165 & Do. \\
\hline 462235 & 961455 & Otter Tall & do. & MN08 & $\mathbf{P}$ & $11-24-80$ & $02-25-81$ & 0.6 & 2.6 & 1,160 & Do. \\
\hline 471331 & 961746 & Norman & do. & MN16 & $\mathbf{P}$ & $11-25-80$ & $02-25-81$ & 0.3 & 3.3 & 1,034 & Do. \\
\hline 485804 & 962656 & KIttson & do. & MN24 & $\mathbf{P}$ & $11-25-80$ & $02-25-81$ & -- & 5.0 & 1,015 & Agricultura1 \& Woodland \\
\hline 480718 & 964005 & Polk & do. & MN17 & $\mathbf{P}$ & $11-25-80$ & $02-26-81$ & -- & 3.8 & 886 & Agricultural \\
\hline
\end{tabular}


TABLE 5.-Dissolved chemical constituent

\begin{tabular}{|c|c|c|c|c|c|c|c|c|c|c|c|c|c|c|c|c|c|c|}
\hline $\begin{array}{l}\text { Lat I- } \\
\text { tude }\end{array}$ & $\begin{array}{l}\text { Longi- } \\
\text { tude }\end{array}$ & $\begin{array}{l}\text { Labora- } \\
\text { tory } \\
\text { iden- } \\
\text { tift- } \\
\text { cation } \\
\text { number }\end{array}$ & $\begin{array}{l}\text { Split } \\
\text { sample } \\
\text { iden } \\
\text { tifi- } \\
\text { cation } \\
\text { number }\end{array}$ & $\begin{array}{c}\text { Sample } \\
\text { type }\end{array}$ & ${ }_{(\mu \mathrm{g} / \mathrm{L})}^{\mathrm{As}}$ & $\begin{array}{c}\text { Ba } \\
(\mu \mathrm{g} / \mathrm{L})\end{array}$ & $\begin{array}{c}B e \\
(\mu g / L)\end{array}$ & $\begin{array}{l}\text { Total } \\
\text { inorganic } \\
\text { carbon } \\
\text { (mg/L) }\end{array}$ & $\begin{array}{c}\mathrm{Ca} \\
(\mathrm{mg} / \mathrm{L})\end{array}$ & $\begin{array}{c}C \mathrm{~d} \\
(\mu \mathrm{g} / \mathrm{L})\end{array}$ & $\underset{(\mathrm{mg} / \mathrm{L})}{\mathrm{Cl}}$ & $\begin{array}{c}C o \\
(\mu g / L)\end{array}$ & $\begin{array}{c}\mathrm{Cu} \\
(\mu \mathrm{g} / \mathrm{L})\end{array}$ & $\underset{(\mathrm{mg} / \mathrm{L})}{\mathrm{F}}$ & $\begin{array}{c}F e \\
(\mu g / L)\end{array}$ & $\begin{array}{c}\mathrm{pH} \\
(\mathrm{Hg} / \mathrm{L})\end{array}$ & $\underset{(\mathrm{Hg} / \mathrm{L})}{\mathrm{Hg}}$ & $\begin{array}{c}\mathrm{K} \\
(\mathrm{mg} / \mathrm{L})\end{array}$ \\
\hline 451040 & 674630 & NE 12 & & $\mathbf{P}$ & $<0.1$ & $<2$ & $<0.5$ & 0.2 & 0.18 & 1 & 1.50 & $<3$ & $<10$ & 0.03 & 9 & 4.4 & $<0.1$ & 0.1 \\
\hline 460310 & 682138 & NE17 & & P & $<0.1$ & $<2$ & $<0.5$ & 0.4 & 0.11 & 8 & 0.98 & $<3$ & $<10$ & 0.03 & 7 & 4.4 & $<0.1$ & 0.1 \\
\hline 444350 & 683936 & NE09 & & $\mathbf{P}$ & $<0.1$ & $<2$ & $<0.5$ & 0.4 & 0.17 & 2 & 2.10 & $<3$ & $<10$ & 0.07 & 32 & 4.3 & $<0.1$ & 0.1 \\
\hline 464426 & 684521 & NE1 8 & & $\mathbf{P}$ & $<0.1$ & $<2$ & $<0.5$ & 0.4 & 0.10 & 3 & 0.15 & $<3$ & $<10$ & 0.07 & 15 & 4.9 & $<0.1$ & $<0.1$ \\
\hline 442736 & 694028 & NE11 & & $\mathbf{P}$ & $<0.1$ & $<2$ & $<0.5$ & 0.4 & 0.38 & 1 & 2.90 & $<3$ & $<10$ & 0.13 & 30 & 4.3 & $<0.1$ & 0.1 \\
\hline 464200 & 694259 & NE14 & & P & $<0.1$ & $<2$ & $<0.5$ & 0.4 & 0.05 & 1 & 0.11 & $<3$ & $<10$ & 0.01 & 4 & 4.8 & $<0.1$ & $<0.1$ \\
\hline 464200 & 694259 & NE25 & NE 14 & -2 & $<0.1$ & $<2$ & $<0.5$ & 0.4 & 0.20 & 8 & 0.13 & 3 & $<10$ & 0.04 & 4 & 4.8 & $<0.1$ & $<0.1$ \\
\hline 450420 & 695412 & NE13 & & P & $<0.1$ & 11 & $<0.5$ & 0.4 & 0.19 & 1 & 2.20 & $<3$ & $<10$ & 0.02 & 13 & 4.2 & $<0.1$ & 0.1 \\
\hline 453938 & 701612 & NE15 & & P & $<0.1$ & $<2$ & $<0.5$ & 0.4 & 0.46 & 9 & 0.36 & $<3$ & $<10$ & 0.01 & 7 & 4.7 & $<0.1$ & 0.3 \\
\hline 442950 & 704144 & NE16 & & $\mathbf{P}$ & $<0.1$ & $<2$ & $<0.5$ & 0.4 & 0.10 & 4 & 1.50 & $<3$ & $<10$ & 0.02 & 13 & 4.3 & $<0.1$ & $<0.1$ \\
\hline 434835 & 704653 & NE10 & & $\mathbf{P}$ & $<0.1$ & $<2$ & $<0.5$ & 0.4 & 0.10 & $<1$ & 1.70 & $<3$ & $<10$ & 0.03 & 8 & 4.4 & $<0.1$ & 0.1 \\
\hline 450250 & 712300 & NE03 & & $\mathbf{P}$ & $<0.1$ & $<2$ & $<0.5$ & 0.4 & 0.09 & 3 & 0.36 & $<3$ & $<10$ & 0.06 & 7 & 4.7 & $<0.1$ & $<0.1$ \\
\hline 430912 & 713634 & $\mathrm{NEO} 2$ & & $\mathrm{P}$ & $<0.1$ & $<2$ & $<0.5$ & 0.4 & 0.09 & 1 & 0.91 & $<3$ & $<10$ & 0.07 & 9 & 4.6 & $<0.1$ & $<0.1$ \\
\hline 430912 & 713634 & NE01 & & $\mathrm{R}$ & $<0.1$ & $<2$ & $<0.5$ & 0.4 & 0.09 & 1 & 1.50 & 3 & $<10$ & 0.14 & 10 & 4.5 & 0.1 & 0.1 \\
\hline 423824 & 713919 & NE20 & & $\mathrm{P}$ & $<0.1$ & $<2$ & $<0.5$ & 0.4 & 0.19 & 1 & 1.60 & $<3$ & $<10$ & 0.06 & 12 & 4.3 & $<0.1$ & 0.1 \\
\hline 423824 & 713919 & NE26 & NE 20 & $\mathrm{z}$ & $<0.1$ & $<2$ & $<0.5$ & 0.2 & 0.21 & 16 & 1.60 & $<3$ & 30 & 0.05 & 13 & 3.9 & $<0.1$ & 0.1 \\
\hline 435651 & 714230 & NE06 & & $\mathrm{P}$ & $<0.1$ & $<2$ & $<0.5$ & 0.4 & 0.10 & 2 & 0.75 & $<3$ & $<10$ & 0.05 & 6 & 4.4 & $<0.1$ & $<0.1$ \\
\hline 435422 & 720923 & NE08 & & $\mathbf{P}$ & $<0.1$ & $<2$ & $<0.5$ & 0.4 & 0.21 & 1 & 0.74 & $<3$ & $<10$ & 0.05 & 17 & 4.6 & $<0.1$ & $<0.1$ \\
\hline 435422 & 720923 & NE27 & NE08 & Z & $<0.1$ & $<2$ & $<0.5$ & 0.4 & 0.58 & $<1$ & 1.00 & 6 & $<10$ & 0.10 & 18 & 5.1 & $<0.1$ & 0.1 \\
\hline 414755 & 722056 & NE22A & & $P$ & $<0.1$ & $<2$ & $<0.5$ & 0.4 & 0.13 & 7 & 1.70 & $<3$ & $<10$ & 0.03 & 22 & 4.5 & 0.1 & 0.1 \\
\hline 414755 & 722056 & NE22B & & $\mathbf{R}$ & $<0.1$ & $<2$ & $<0.5$ & 0.4 & 0.19 & 5 & 1.70 & 3 & $<10$ & 0.04 & 27 & 4.0 & $<0.1$ & $<0.1$ \\
\hline 421959 & 722104 & NE21 & & $P$ & $<0.1$ & $<2$ & $<0.5$ & 0.4 & 0.18 & $<1$ & 1.10 & $<3$ & $<10$ & 0.09 & 14 & 4.4 & 0.1 & 0.1 \\
\hline 443355 & 723431 & NE07 & & $\mathrm{p}$ & $<0.1$ & $<2$ & $<0.5$ & 0.6 & 0.16 & $<1$ & 0.69 & $<3$ & $<10$ & 0.06 & 27 & 4.5 & $<0.1$ & $<0.1$ \\
\hline 440620 & 724445 & NE04 & & $\mathbf{P}$ & $<0.1$ & $<2$ & $<0.5$ & 0.4 & 0.05 & 5 & 0.14 & $<3$ & $<10$ & 0.07 & $<3$ & 4.8 & $<0.1$ & 0.1 \\
\hline 430725 & 724636 & NE05 & & $\mathrm{P}$ & $<0.1$ & $<2$ & $<0.5$ & 0.4 & 0.09 & $<1$ & 0.59 & $<3$ & $<10$ & 0.07 & 9 & 4.4 & $<0.1$ & $<0.1$ \\
\hline 415648 & 725017 & NE23 & & $\mathrm{P}$ & $<0.1$ & $<2$ & $<0.5$ & 0.4 & 0.15 & 1 & 0.92 & $<3$ & $<10$ & 0.05 & 5 & 4.6 & $<0.1$ & 0.1 \\
\hline 424102 & 725659 & NE 19 & & P & $<0.1$ & $<2$ & $<0.5$ & 0.4 & 0.11 & 1 & 0.62 & $<3$ & $<10$ & 0.04 & 9 & 4.5 & $<0.1$ & $<0.1$ \\
\hline 415823 & 731313 & NE 24 & & $P$ & $<0.1$ & $<2$ & $<0.5$ & 0.4 & 0.30 & 1 & 1.80 & $<3$ & $<10$ & 0.05 & 13 & 4.4 & 0.2 & 0.1 \\
\hline 434310 & 732802 & NY 14 & & $P$ & $<0.1$ & $<2$ & $<0.5$ & 0.4 & 0.25 & 3 & 0.41 & $<3$ & 10 & 0.01 & 15 & 4.3 & $<0.1$ & $<0.1$ \\
\hline 445406 & 732930 & NY06 & & P & $<0.1$ & $<2$ & $<0.5$ & 0.4 & 0.58 & $<1$ & 0.30 & $<3$ & 20 & 0.09 & 22 & 4.1 & $<0.1$ & $<0.1$ \\
\hline 445406 & 732930 & NY35 & NY06 & 2 & $<0.1$ & 2 & $<0.5$ & 0.4 & 0.65 & 4 & 0.30 & $<3$ & 10 & 0.05 & 20 & 4.2 & $<0.1$ & $<0.1$ \\
\hline 422211 & 733010 & NY05 & & $P$ & $<0.1$ & $<2$ & $<0.5$ & 0.4 & 0.38 & $<1$ & 0.52 & $<3$ & $<10$ & 0.24 & 21 & 4.3 & 0.1 & 0.1 \\
\hline 442405 & 735121 & NY 20 & & $P$ & $<0.1$ & $<2$ & $<0.5$ & 0.4 & 0.22 & 5 & 0.16 & $<3$ & 20 & 0.03 & 9 & 4.3 & $<0.1$ & $<0.1$ \\
\hline 442405 & 735121 & NY25 & & $\mathbf{R}$ & $<0.1$ & $<2$ & $<0.5$ & 0.4 & 0.21 & 6 & 0.23 & $<3$ & 10 & 0.01 & 14 & 4.2 & $<0.1$ & $<0.1$ \\
\hline 442405 & 735121 & NY37A & & A & $<0.1$ & $<2$ & $<0.5$ & 0.1 & 0.25 & 2 & 0.38 & $<3$ & $<10$ & 0.05 & 17 & 4.5 & $<0.1$ & 0.1 \\
\hline 442405 & 735121 & NY37B & & B & -- & 2 & $<0.5$ & 0.3 & 0.43 & 6 & 0.51 & $<3$ & $<10$ & 0.07 & $<3$ & 5.7 & -- & 0.2 \\
\hline 442405 & 735121 & NY37C & & c & -- & 4 & $<0.5$ & 0.4 & 0.65 & 6 & 0.92 & $<3$ & $<10$ & 0.06 & $<3$ & 6.1 & -- & 0.4 \\
\hline 442405 & 735121 & NY21 & & 0 & $<0.1$ & $<2$ & $<0.5$ & 0.4 & 0.14 & $<1$ & 0.15 & $<3$ & $<10$ & 0.04 & $<3$ & 4.2 & $<0.1$ & $<0.1$ \\
\hline 442405 & 735121 & NY23 & & $\mathbf{s}$ & $<0.1$ & $<2$ & $<0.5$ & 0.4 & 0.10 & $<1$ & 0.18 & $<3$ & $<10$ & 0.02 & 8 & 4.3 & $<0.1$ & 0.1 \\
\hline 432715 & 740025 & NY13 & & P & $<0.1$ & $<2$ & $<0.5$ & 0.4 & 0.29 & 5 & 0.41 & $<3$ & 10 & 0.02 & 18 & 4.2 & $<0.1$ & $<0.1$ \\
\hline 424708 & 741955 & NY 19 & & $P$ & $<0.1$ & $<2$ & $<0.5$ & 0.4 & 0.61 & 1 & 0.33 & $<3$ & 10 & 0.02 & 31 & 4.2 & $<0.1$ & 0.1 \\
\hline 424708 & 741955 & NY28 & & $\mathbf{R}$ & $<0.1$ & $<2$ & $<0.5$ & 0.4 & 0.29 & 4 & 0.29 & $<3$ & $<10$ & 0.01 & 23 & 4.3 & $<0.1$ & $<0.1$ \\
\hline 424708 & 741955 & NY 26 & & s & $<0.1$ & $<2$ & $<0.5$ & 0.4 & 0.33 & 7 & 0.18 & $<3$ & 30 & 0.04 & 13 & 4.7 & $<0.1$ & $<0.1$ \\
\hline 424708 & 741955 & NY32 & NY28 & $\mathrm{z}$ & $<0.1$ & $<2$ & $<0.5$ & 0.4 & 0.31 & 7 & 0.33 & $<3$ & 30 & 0.04 & 21 & 4.2 & $<0.1$ & $<0.1$ \\
\hline 410921 & 742651 & NJOI & & $\mathbf{P}$ & $<0.1$ & 2 & $<0.5$ & 0.8 & 0.19 & 5 & 2.10 & $<3$ & $<10$ & 0.01 & 12 & 4.2 & $<0.1$ & 0.1 \\
\hline 414158 & 742714 & NY09 & & $\mathbf{P}$ & $<0.1$ & 3 & $<0.5$ & 0.4 & 1.10 & 1 & 0.14 & $<3$ & 10 & 0.02 & 24 & 5.3 & $<0.1$ & 0.6 \\
\hline 434224 & 745428 & NY16 & & P & $<0.1$ & $<2$ & $<0.5$ & 0.4 & 0.21 & $<1$ & 0.12 & $<3$ & $<10$ & 0.09 & 11 & 4.2 & $<0.1$ & $<0.1$ \\
\hline 434224 & 745428 & NY24 & & $\mathbf{R}$ & 1.0 & $<2$ & $<0.5$ & 0.4 & 0.23 & 5 & 0.04 & $<3$ & 10 & 0.10 & 11 & 4.9 & $<0.1$ & $<0.1$ \\
\hline 434224 & 745428 & NY29 & & A & $<0.1$ & 23 & $<0.5$ & 0.4 & 0.48 & 3 & 0.52 & $<3$ & 10 & 0.01 & 43 & 5.1 & $<0.1$ & 0.2 \\
\hline 434224 & 745428 & NY31 & NY16 & 2 & $<0.1$ & 6 & $<0.5$ & 0.4 & 0.19 & 38 & 0.24 & $<3$ & 80 & 0.04 & 12 & 4.3 & $<0.1$ & $<0.1$ \\
\hline
\end{tabular}




\begin{tabular}{|c|c|c|c|c|c|c|c|c|c|c|c|c|c|c|c|c|c|c|}
\hline $\begin{array}{l}\text { Labora- } \\
\text { tory } \\
\text { iden- } \\
\text { tifi- } \\
\text { cation } \\
\text { number }\end{array}$ & $\underset{(H g / L)}{L I}$ & $\underset{(\mathrm{mg} / \mathrm{L})}{\mathrm{Mg}}$ & $\begin{array}{c}M n \\
(\mathrm{Hg} / \mathrm{L})\end{array}$ & $\begin{array}{c}\text { Mo } \\
(\mu \mathrm{g} / \mathrm{L})\end{array}$ & $\begin{array}{l}\mathrm{NH}_{4}-\mathrm{N} \\
(\mathrm{mg} / \mathrm{L})\end{array}$ & $\begin{array}{r}\mathrm{NO}_{3}-\mathrm{N} \\
(\mathrm{mg} / \mathrm{L})\end{array}$ & $\begin{array}{c}\mathrm{Na} \\
(\mathrm{mg} / \mathrm{L})\end{array}$ & $\begin{array}{c}N 1 \\
(\mu \mathrm{g} / \mathrm{L})\end{array}$ & $\begin{array}{c}\mathrm{Pb} \\
\left(\mu_{\mathrm{g}} / \mathrm{L}\right)\end{array}$ & $\begin{array}{c}\mathrm{Se} \\
(\mu \mathrm{g} / \mathrm{L})\end{array}$ & $\begin{array}{c}S i \\
(\mu g / L)\end{array}$ & $\begin{array}{c}\mathrm{SO}_{4} \\
(\mathrm{~m} / \mathrm{L})\end{array}$ & $\begin{array}{c}\mathrm{Sr} \\
(\mu \mathrm{g} / \mathrm{L})\end{array}$ & $\begin{array}{c}V \\
(\mu \mathrm{g} / \mathrm{L})\end{array}$ & $\begin{array}{c}\mathrm{Zn} \\
(\mathrm{Hg} / \mathrm{L})\end{array}$ & $\begin{array}{l}\text { Cations } \\
\text { sum } \\
\text { (meq/L) }\end{array}$ & $\begin{array}{l}\text { Anions } \\
\text { suin } \\
\text { (meq/L) }\end{array}$ & $\begin{array}{l}\text { Specific } \\
\text { conductance } \\
(\mu \mathrm{mho} / \mathrm{cm} \\
\left(225^{\circ} \mathrm{C}\right)\end{array}$ \\
\hline NE12 & 51 & 0.4 & 6 & $<10$ & 0.07 & 0.3 & 0.9 & $<1$ & 5 & $<0.1$ & 0.280 & 1.60 & 3.6 & $<6$ & 5 & 0.126 & 0.097 & 16.0 \\
\hline NE17 & 56 & 0.5 & .1 & $<10$ & 0.06 & 0.3 & 0.5 & 1 & 78 & $<0.1$ & 0.240 & 1.40 & 2.6 & $<6$ & 9 & 0.112 & 0.078 & 15.0 \\
\hline NE09 & 50 & 0.4 & 2 & $<10$ & 0.08 & 0.4 & 1.3 & $<1$ & 5 & $<0.1$ & 0.260 & 2.00 & 4.0 & $<6$ & 4 & 0.154 & 0.129 & 23.0 \\
\hline NE 18 & 56 & 0.5 & 1 & $<10$ & $<0.01$ & 0.1 & 0.3 & 3 & 8 & $<0.1$ & 0.240 & 0.41 & 2.5 & $<6$ & $<3$ & 0.072 & 0.020 & 3.0 \\
\hline NE11 & 47 & 0.1 & 10 & $<10$ & 0.29 & 0.5 & 1.3 & 1 & 9 & $<0.1$ & $<0.009$ & 2.90 & 3.6 & 7 & 7 & 0.155 & 0.178 & 27.0 \\
\hline NE14 & 51 & 0.3 & 1 & $<10$ & $<0.01$ & 0.1 & 0.2 & $<1$ & $<1$ & $<0.1$ & 0.330 & 0.44 & 3.1 & $<6$ & $<3$ & 0.052 & 0.019 & 3.9 \\
\hline NE25 & 50 & 0.6 & 1 & $<10$ & $<0.01$ & 0.1 & 0.3 & $<1$ & 2 & $<0.1$ & 0.400 & 0.61 & 5.2 & $<6$ & $<3$ & 0.088 & 0.023 & 1.8 \\
\hline NE13 & 55 & 0.6 & 3 & $<10$ & 0.12 & 0.4 & 1.4 & $<1$ & 8 & $<0.1$ & 0.037 & 2.30 & 2.8 & $<6$ & 9 & 0.191 & 0.138 & 28.0 \\
\hline NE15 & 56 & 0.4 & 10 & $<10$ & $<0.01$ & 0.2 & 0.4 & $<1$ & 4 & $<0.1$ & 0.150 & 1.30 & 2.9 & $<6$ & 12 & 0.093 & 0.051 & 8.9 \\
\hline NE16 & 52 & 0.6 & 1 & $<10$ & 0.07 & 0.3 & 1.1 & $<1$ & 5 & $<0.1$ & 0.150 & 1.90 & 2.8 & $<6$ & 4 & 0.157 & 0.103 & 19.0 \\
\hline NE1O & 47 & 0.4 & 1 & $<10$ & 0.05 & 0.2 & 1.1 & 2 & 8 & $<0.1$ & 0.140 & 1.40 & 2.7 & $<6$ & 3 & 0.129 & 0.091 & 15.0 \\
\hline NE03 & 47 & 0.3 & l & $<10$ & 0.05 & 0.1 & 0.3 & 3 & 1 & $<0.1$ & 0.021 & 0.59 & 1.9 & $<6$ & 25 & 0.066 & 0.030 & 4.0 \\
\hline NEO2 & 47 & 0.4 & $<1$ & $<10$ & $<0.01$ & 0.1 & 0.6 & $<1$ & 2 & $<0.1$ & 0.031 & 1.10 & 2.3 & $<6$ & 7 & 0.089 & 0.056 & 7.2 \\
\hline NEOI & 43 & 0.4 & $<1$ & $<10$ & $<0.01$ & 0.1 & 0.8 & 4 & 2 & $<0.1$ & 0.070 & 1.30 & 2.8 & $<6$ & 9 & 0.104 & 0.076 & 10.0 \\
\hline NE20 & 55 & 0.6 & 2 & $<10$ & 0.07 & 0.3 & 1.2 & $<1$ & 5 & $<0.1$ & 0.220 & 1.80 & 3.6 & $<6$ & 40 & 0.166 & 0.104 & 21.0 \\
\hline NE2 6 & 47 & 0.6 & 2 & $<10$ & 0.06 & 0.3 & 1.1 & 2 & 6 & $<0.1$ & 0.400 & 1.80 & 3.9 & $<6$ & 44 & 0.238 & 0.104 & 17.0 \\
\hline NE06 & 48 & 0.3 & 1 & $<10$ & 0.06 & 0.3 & 0.5 & 3 & 5 & $<0.1$ & 0.028 & 1.20 & 2.3 & $<6$ & 33 & 0.096 & 0.068 & 12.0 \\
\hline NE08 & 52 & 0.4 & 2 & $<10$ & 0.06 & 0.3 & 0.6 & 1 & 5 & $<0.1$ & 0.180 & 1.10 & 3.0 & $<6$ & $<3$ & 0.099 & 0.065 & 10.0 \\
\hline NE27 & 53 & 0.5 & 2 & $<10$ & 0.05 & 0.3 & 0.8 & 2 & 4 & $<0.1$ & 0.380 & 1.70 & 4.5 & $<6$ & 9 & 0.116 & 0.085 & 8.7 \\
\hline NE22A & 55 & 0.6 & 1 & $<10$ & 0.09 & 0.3 & 1.2 & $<1$ & 11 & $<0.1$ & $<0.009$ & 1.50 & 1.6 & $<6$ & 7 & 0.146 & 0.101 & 18.0 \\
\hline NE22B & 49 & 0.5 & 2 & $<10$ & 0.09 & 0.3 & 1.2 & $<1$ & 11 & $<0.1$ & 0.480 & 1.50 & 5.6 & $<6$ & 7 & 0.209 & 0.101 & 23.0 \\
\hline NE21 & 58 & 0.6 & l & $<10$ & 0.06 & 0.3 & 0.8 & 1 & 8 & $<0.1$ & 0.260 & 1.50 & 3.1 & $<6$ & 15 & 0.137 & 0.084 & 15.0 \\
\hline NE07 & 53 & $<0.1$ & 3 & $<10$ & 0.13 & 0.4 & 0.3 & 3 & 10 & $<0.1$ & $<0.009$ & 1.30 & 2.7 & $<6$ & 93 & 0.062 & 0.075 & 12.0 \\
\hline NEO4 & 46 & 0.3 & $<1$ & $<10$ & $<0.01$ & 0.1 & 0.3 & 5 & $<1$ & $<0.1$ & $<0.009$ & 0.40 & 1.4 & $<6$ & 11 & 0.056 & 0.019 & 1.6 \\
\hline NEOS & 48 & 0.4 & 1 & $<10$ & $<0.01$ & 0.3 & 0.5 & $<1$ & 1 & $<0.1$ & 0.049 & 1.20 & 2.3 & $<6$ & 19 & 0.099 & 0.063 & $1 i .0$ \\
\hline NE23 & 54 & 0.5 & 3 & $<10$ & 0.05 & 0.1 & 0.7 & $<1$ & i & $<0.1$ & 0.190 & 1.10 & 3.3 & $<6$ & $<3$ & 0.108 & 0.056 & 9.6 \\
\hline NE19 & 59 & 0.5 & 1 & $<10$ & 0.10 & 0.2 & 0.5 & 1 & 4 & $<0.1$ & 0.170 & 1.20 & 2.4 & $<6$ & 11 & 0.107 & 0.057 & 11.0 \\
\hline NE24 & 50 & 0.7 & 5 & $<10$ & 0.08 & $0 . \overline{4}$ & 1.2 & 1 & 9 & $<0.1$ & 0.470 & 2.30 & 5.5 & $<6$ & $<3$ & 0.170 & 0.127 & 21.0 \\
\hline NY14 & 9 & $<0.1$ & 2 & $<10$ & 0.08 & 0.4 & 0.3 & $<1$ & 6 & $<0.1$ & 0.130 & 1.30 & 2.8 & $<6$ & $<3$ & 0.081 & 0.067 & 22.0 \\
\hline NY06 & 4 & 0.3 & 6 & $<10$ & 0.12 & 0.6 & 0.3 & $<1$ & 4 & $<0.1$ & 0.130 & 2.20 & 2.7 & $<6$ & 17 & 0.155 & 0.097 & 23.0 \\
\hline NY35 & 10 & $<0.1$ & 5 & $<10$ & 0.14 & 0.6 & 0.2 & 2 & 4 & $<0.1$ & 0.130 & 1.90 & 2.4 & $<6$ & 15 & 0.114 & 0.091 & 20.0 \\
\hline NYOS & $<4$ & 0.2 & 4 & $<10$ & 0.14 & 0.4 & 0.5 & $<1$ & 9 & $<0.1$ & 0.098 & 1.80 & 1.8 & $<6$ & 10 & 0.117 & 0.081 & 20.0 \\
\hline NY20 & 4 & $<0.1$ & 2 & $<10$ & 0.10 & 0.4 & $<0.2$ & $<1$ & 5 & $<0.1$ & 0.110 & 1.30 & 2.2 & $<6$ & $<3$ & 0.068 & 0.060 & 15.0 \\
\hline NY25 & 11 & 0.2 & 2 & $<10$ & 0.13 & 0.5 & $<0.2$ & $<1$ & 4 & $<0.1$ & 0.330 & 1.50 & 3.6 & $<6$ & 23 & 0.099 & 0.073 & 17.0 \\
\hline NY37A & $<4$ & $<0.1$ & 2 & $<10$ & 0.38 & 0.3 & $<0.2$ & $<1$ & 4 & $<0.1$ & 0.250 & 1.70 & 2.0 & $<6$ & 32 & 0.071 & 0.067 & 8.0 \\
\hline NY37B & $<4$ & $<0.1$ & 2 & $<10$ & 0.52 & 0.2 & 0.3 & 4 & 1 & $<0.1$ & 0.190 & 0.60 & 3.0 & $<6$ & 129 & 0.074 & 0.041 & 6.0 \\
\hline $\mathrm{NY} 37 \mathrm{C}$ & $<4$ & $<0.1$ & 5 & $<10$ & 0.75 & 0.2 & 0.6 & 4 & 1 & $<0.1$ & 0.130 & 1.00 & 3.0 & $<6$ & 156 & 0.113 & 0.061 & 10.0 \\
\hline NY21 & $<4$ & $<0.1$ & l & $<10$ & 0.17 & 0.5 & $<0.2$ & 2 & 1 & $<0.1$ & 0.020 & 1.50 & 1.4 & $<6$ & 6 & 0.082 & 0.071 & 16.0 \\
\hline NY23 & $<4$ & $<0.1$ & $i$ & $<10$ & 0.14 & 0.4 & $<0.2$ & 3 & 3 & $<0.1$ & 0.022 & 1.50 & 3.5 & $<6$ & 13 & 0.065 & 0.065 & 14.0 \\
\hline NY13 & 8 & 0.1 & 1 & $<10$ & 0.10 & 0.5 & 0.2 & $<1$ & 8 & $<0.1$ & 0.250 & 2.50 & 3.1 & $<6$ & 20 & 0.102 & 0.099 & 13.0 \\
\hline NY19 & 10 & 0.1 & 5 & $<10$ & 0.17 & 0.6 & 0.3 & $<1$ & 6 & $<0.1$ & 0.052 & 2.20 & 3.3 & $<6$ & 7 & 0.127 & 0.098 & 12.0 \\
\hline NY28 & 14 & 0.2 & 2 & $<10$ & 0.18 & 0.5 & 0.3 & 13 & 5 & $<0.1$ & 0.210 & 1.80 & 3.2 & $<6$ & 27 & 0.107 & 0.081 & 11.0 \\
\hline NY26 & 13 & 0.3 & 2 & $<10$ & 0.18 & 0.4 & 0.2 & $<1$ & 4 & $<0.1$ & 0.230 & 1.30 & 3.5 & $<6$ & 13 & 0.083 & 0.061 & 46.0 \\
\hline $\mathrm{NY} 32$ & 12 & $<0.1$ & 2 & $<10$ & 0.15 & 0.5 & 0.2 & 1 & 5 & $<0.1$ & 0.100 & 1.80 & 2.1 & $<6$ & 12 & 0.098 & 0.082 & 18.0 \\
\hline NJOI & 28 & 0.1 & 2 & $<10$ & 0.08 & 0.4 & 1.3 & I & 9 & $<0.1$ & 0.076 & 2.10 & 2.4 & $<6$ & 9 & 0.143 & 0.131 & 25.0 \\
\hline NYO9 & $<4$ & 0.3 & 67 & $<10$ & $<0.01$ & 0.2 & 0.9 & $<1$ & 2 & $<0.1$ & 0.800 & 2.70 & 3.8 & $<6$ & 47 & 0.124 & 0.074 & 16.0 \\
\hline NY16 & $<4$ & $<0.1$ & I & $<10$ & 0.14 & 0.5 & $<0.2$ & $<1$ & 6 & $<0.1$ & 0.018 & 5.70 & $<0.5$ & $<6$ & 8 & 0.084 & 0.157 & 11.0 \\
\hline NY 24 & 11 & 0.3 & $i$ & $<10$ & 0.09 & 0.2 & 0.2 & $<i$ & 3 & $<0.1$ & 0.350 & 0.35 & 4.2 & $<6$ & 27 & 0.064 & 0.023 & 3.6 \\
\hline NY29 & 11 & 0.1 & 4 & $<10$ & $<0.01$ & 0.1 & 0.3 & $<1$ & 43 & $<0.1$ & 0.210 & 2.30 & 5.1 & $<6$ & 34 & 0.032 & 0.062 & 0.2 \\
\hline NY 31 & 10 & 0.1 & 2 & $<10$ & 0.15 & 0.5 & $<0.2$ & 4 & 4 & $<0.1$ & 0.230 & 1.40 & 2.3 & $<6$ & 28 & 0.079 & 0.072 & 13.0 \\
\hline
\end{tabular}


TABLE 5. - Dissolved chemical constituent

\begin{tabular}{|c|c|c|c|c|c|c|c|c|c|c|c|c|c|c|c|c|c|c|}
\hline $\begin{array}{l}\text { Lat1- } \\
\text { tude }\end{array}$ & $\begin{array}{l}\text { Longi- } \\
\text { tude }\end{array}$ & $\begin{array}{l}\text { Labora- } \\
\text { tory } \\
\text { iden- } \\
\text { tifi- } \\
\text { cation } \\
\text { number }\end{array}$ & $\begin{array}{l}\text { Split } \\
\text { sample } \\
\text { iden } \\
\text { tifi- } \\
\text { cation } \\
\text { number }\end{array}$ & $\begin{array}{c}\text { Sample } \\
\text { type }\end{array}$ & $\begin{array}{c}\text { As } \\
(\mu \mathrm{g} / \mathrm{L})\end{array}$ & $\begin{array}{c}\mathrm{Ba} \\
(\mu \mathrm{g} / \mathrm{L})\end{array}$ & $\begin{array}{c}\mathrm{Be} \\
(\mu \mathrm{g} / \mathrm{L})\end{array}$ & $\begin{array}{l}\text { Total } \\
\text { 1norganic } \\
\text { carbon } \\
(\mathrm{mg} / \mathrm{L})\end{array}$ & $\begin{array}{c}\mathrm{Ca} \\
(\mathrm{mg} / \mathrm{L})\end{array}$ & $\begin{array}{c}\mathrm{Cd} \\
(\mu \mathrm{g} / \mathrm{L})\end{array}$ & $\underset{(\mathrm{mg} / \mathrm{L})}{\mathrm{Cl}}$ & $\begin{array}{c}\text { Co } \\
(\mu \mathrm{g} / \mathrm{L})\end{array}$ & $\begin{array}{c}\mathrm{Cu} \\
(\mu \mathrm{g} / \mathrm{L})\end{array}$ & $\begin{array}{c}F \\
(\mathrm{mg} / \mathrm{L})\end{array}$ & $\begin{array}{c}\mathrm{Fe} \\
(\mu \mathrm{g} / \mathrm{L})\end{array}$ & $\begin{array}{c}\mathrm{pH} \\
(\mu \mathrm{g} / \mathrm{L})\end{array}$ & $\begin{array}{c}\mathrm{Hg} \\
(1 \mathrm{~g} / \mathrm{L})\end{array}$ & $\begin{array}{c}\mathrm{K} \\
(\mathrm{mg} / \mathrm{L})\end{array}$ \\
\hline 410547 & 745800 & $\mathrm{NJ} 02$ & & $\mathbf{P}$ & $<0.1$ & $<2$ & $<0.5$ & 0.1 & 0.19 & 1 & 1.80 & $<3$ & $<10$ & 0.07 & 14 & 4.3 & $<0.1$ & 0.1 \\
\hline 410547 & 745800 & NJ04 & & $\mathbf{R}$ & $<0.1$ & $<2$ & $<0.5$ & 0.4 & 0.18 & $<1$ & 1.80 & $<3$ & $<10$ & 0.01 & 24 & 4.2 & $<0.1$ & 0.1 \\
\hline 410547 & 745800 & NJ05A & & A. & $x<0.1$ & 3 & $<0.5$ & 0.4 & 0.24 & 2 & 0.66 & 3 & $<10$ & 0.02 & 26 & 4.2 & $<0.1$ & $<0.1$ \\
\hline 410547 & 745800 & NJ05B & & B & 1.0 & 3 & $<0.5$ & 0.4 & 0.92 & 5 & 1.20 & $<3$ & $<10$ & 0.03 & 27 & 3.8 & $<0.1$ & 0.2 \\
\hline 410547 & 745800 & NN05C & & D & $<0.1$ & $<2$ & $<0.5$ & 0.4 & 0.17 & 1 & 1.80 & $<3$ & $<10$ & 0.04 & 9 & 3.9 & $<0.1$ & 0.1 \\
\hline 410219 & 745945 & $\mathrm{NJ} 03$ & & $\mathbf{P}$ & 1.0 & $<2$ & $<0.5$ & 0.4 & 0.20 & $<1$ & 1.90 & $<3$ & $<10$ & 0.01 & 19 & 4.2 & $<0.1$ & $<0.1$ \\
\hline 421710 & 750538 & NY 10 & & P & 1.0 & $<2$ & $<0.5$ & 0.4 & 0.26 & 3 & 0.32 & $<3$ & 10 & 0.01 & 35 & 4.3 & $<0.1$ & $<0.1$ \\
\hline 443535 & 751353 & $\mathrm{NYO4}$ & & $P$ & $<0.1$ & 5 & $<0.5$ & 0.4 & 0.32 & 14 & 0.48 & $<3$ & 100 & 0.09 & 18 & 4.0 & $<0.1$ & 0.1 \\
\hline 413519 & 751954 & PA18 & & P & 1.0 & $<2$ & $<0.5$ & 0.2 & 0.18 & 6 & 0.80 & $<3$ & 30 & 0.06 & 35 & 4.2 & $<0.1$ & $<0.1$ \\
\hline 413519 & 751954 & PA08 & & $\mathbf{R}$ & 1.0 & $<2$ & $<0.5$ & 0.4 & 0.14 & $<1$ & 0.34 & $<3$ & $<10$ & 0.03 & 14 & 4.3 & $<0.1$ & $<0.1$ \\
\hline 413519 & 751954 & PA25 & PA18 & $\mathrm{Z}$ & $<0.1$ & $<2$ & $<0.5$ & 0.2 & 0.23 & $<1$ & 0.90 & $<3$ & $<10$ & 0.06 & 19 & 4.2 & $<0.1$ & $<0.1$ \\
\hline 424854 & 752634 & NY07 & & $\mathrm{P}$ & $<0.1$ & 2 & $<0.5$ & 0.4 & 0.57 & $<1$ & 0.54 & $<3$ & $<10$ & 0.04 & 33 & 5.3 & $<0.1$ & $<0.1$ \\
\hline 421225 & 754242 & $\mathrm{NYO1}$ & & $\mathrm{P}$ & $<0.1$ & 2 & $<0.5$ & 0.4 & 0.35 & 3 & 0.25 & $<3$ & $<10$ & 0.06 & 32 & 4.2 & $<0.1$ & $<0.1$ \\
\hline 432842 & 754438 & NY 17 & & $\mathbf{P}$ & 1.0 & 2 & $<0.5$ & 0.4 & 0.20 & 1 & 0.22 & $<3$ & 20 & 0.03 & 22 & 4.3 & $<0.1$ & $<0.1$ \\
\hline 404826 & 760030 & PA07 & & $\mathbf{P}$ & 1.0 & $<2$ & $<0.5$ & 0.4 & 0.65 & $<1$ & 1.00 & $<3$ & $<10$ & 0.05 & 14 & 4.2 & $<0.1$ & 0.1 \\
\hline 420126 & 761318 & $\mathrm{NYO2}$ & & $\mathrm{P}$ & $<0.1$ & $<2$ & $<0.5$ & 0.4 & 0.26 & 1 & 0.43 & $<3$ & $<10$ & 0.08 & 25 & 4.2 & $<0.1$ & $<0.1$ \\
\hline 420126 & 761318 & NY33 & NY02 & $z$ & $<0.1$ & 2 & $<0.5$ & 0.4 & 0.32 & 6 & 0.43 & $<3$ & 20 & 0.04 & 29 & 4.3 & $<0.1$ & 0.1 \\
\hline 412821 & 763455 & PA10 & & $\mathbf{P}$ & $<0.1$ & $<2$ & $<0.5$ & 0.4 & 0.27 & 191 & 0.16 & $<3$ & 120 & 0.03 & 26 & 4.2 & $<0.1$ & $<0.1$ \\
\hline 422358 & 763913 & NYI1 & & $\mathrm{P}$ & 1.0 & $<2$ & $<0.5$ & 0.4 & 0.32 & 4 & 0.37 & $<3$ & 10 & 0.03 & 32 & 4.1 & $<0.1$ & $<0.1$ \\
\hline 422358 & 763913 & NY27 & & $\mathbf{R}$ & 1.0 & $<2$ & $<0.5$ & 0.4 & 0.24 & $<1$ & 0.46 & $<3$ & $<10$ & 0.06 & 21 & 4.1 & $<0.1$ & 0.1 \\
\hline 422358 & 763913 & NY22A & & A & 1.0 & 2 & $<0.5$ & 0.1 & 0.89 & 5 & 0.97 & $<3$ & 20 & 0.10 & 111 & 7.2 & $<0.1$ & 0.1 \\
\hline 422358 & 763913 & $\mathrm{NY} 22 \mathrm{~B}$ & & B & $<0.1$ & $<2$ & $<0.5$ & 0.4 & 0.37 & 5 & 0.79 & $<3$ & 10 & 0.06 & 44 & 4.1 & $<0.1$ & 0.1 \\
\hline 422358 & 763913 & NY22C & & $\mathrm{C}$ & 1.0 & 7 & $<0.5$ & 0.4 & 2.00 & 14 & 1.20 & $<3$ & 50 & 0.04 & 235 & 5.1 & 0.1 & 0.2 \\
\hline 422358 & 763913 & NY22D & & $D$ & 1.0 & $<2$ & $<0.5$ & 0.4 & 0.38 & 3 & 0.55 & $<3$ & 10 & 0.04 & 26 & 4.2 & $<0.1$ & 0.1 \\
\hline 422358 & 763913 & NY30 & & $\mathrm{s}$ & 1.0 & 4 & $<0.5$ & 0.3 & 0.38 & $<1$ & 0.67 & $<3$ & $<10$ & 0.03 & 37 & 5.5 & 0.2 & 0.1 \\
\hline 422358 & 763913 & NY34 & NY11 & $\mathrm{z}$ & 1.0 & $<2$ & $<0.5$ & 0.4 & 0.36 & 4 & 0.47 & $<3$ & 20 & 0.04 & 30 & 4.1 & $<0.1$ & $<0.1$ \\
\hline 422358 & 763913 & NY36 & NY 22B & z & 1.0 & 4 & $<0.5$ & 0.4 & 0.42 & 1 & 0.79 & $<3$ & 10 & 0.09 & 39 & 4.1 & $<0.1$ & 0.1 \\
\hline 430653 & 764829 & NY15 & & $\mathbf{P}$ & 1.0 & $<2$ & $<0.5$ & 0.4 & 0.45 & 3 & 0.61 & $<3$ & 10 & 0.02 & 39 & 4.2 & $<0.1$ & $<0.1$ \\
\hline 405452 & 771310 & PA13 & & P & 1.0 & $<2$ & $<0.5$ & 0.4 & 0.33 & $<1$ & 1.10 & $<3$ & $<10$ & 0.04 & 18 & 4.2 & $<0.1$ & 0.1 \\
\hline 405452 & 771310 & PA24 & PA13 & 7. & 1.0 & $<2$ & $<0.5$ & 0.4 & 0.39 & 2 & 0.72 & $<3$ & $<10$ & 0.09 & 16 & 4.3 & $<0.1$ & 0.1 \\
\hline 400147 & 771741 & PA14 & & P & 1.0 & $<2$ & $<0.5$ & 0.4 & 0.25 & $<1$ & 0.42 & $<3$ & $<10$ & 0.04 & 14 & 4.3 & $<0.1$ & 0.1 \\
\hline 400147 & 771741 & PA22 & PA14 & 7 & $<0.1$ & $<2$ & $<0.5$ & 0.4 & 0.34 & 27 & 1.30 & $<3$ & 30 & 0.06 & 14 & 4.3 & $<0.1$ & 0.1 \\
\hline 420630 & 773206 & NY12 & & $\mathbf{P}$ & $<0.1$ & $<2$ & $<0.5$ & 0.6 & 0.40 & 5 & 0.24 & $<3$ & 10 & 0.05 & 40 & 4.2 & $<0.1$ & 0.1 \\
\hline 412121 & 775532 & PA09 & & P & 1.0 & $<2$ & $<0.5$ & 0.4 & 0.20 & $<1$ & 0.38 & $<3$ & $<10$ & 0.08 & 26 & 4.1 & $<0.1$ & $<0.1$ \\
\hline 412121 & 775532 & PA21 & PA09 & 2 & 1.0 & $<2$ & $<0.5$ & 0.4 & 0.22 & $<1$ & 0.29 & $<3$ & $<10$ & 0.09 & 12 & 4.1 & $<0.1$ & $<0.1$ \\
\hline 404718 & 775643 & PA15 & & P & 1.0 & $<2$ & $<0.5$ & 0.4 & 0.33 & $<1$ & 0.20 & $<3$ & $<10$ & 0.04 & 32 & 4.1 & $<0.1$ & $<0.1$ \\
\hline 404718 & 775643 & PAl1 & & $\mathbf{R}$ & $<0.1$ & $<2$ & $<0.5$ & 0.4 & 0.16 & $<1$ & 0.61 & 3 & $<10$ & 0.04 & 21 & 4.4 & $<0.1$ & $<0.1$ \\
\hline 404718 & 775643 & PA16 & & A & $<0.1$ & $<2$ & $<0.5$ & 0.4 & 0.26 & $<1$ & 0.27 & $<3$ & $<10$ & 0.08 & 9 & 4.8 & $<0.1$ & $<0.1$ \\
\hline 404718 & 775643 & PA20 & & B & 1.0 & $<2$ & $<0.5$ & 0.1 & 0.44 & $<1$ & 0.60 & $<3$ & $<10$ & 0.06 & 31 & 5.0 & $<0.1$ & $<0.1$ \\
\hline 404718 & 775643 & PA17 & & $c$ & $<0.1$ & $<2$ & $<0.5$ & 0.1 & 0.23 & 5 & 0.24 & $<3$ & $<10$ & 0.05 & 12 & 4.7 & $<0.1$ & $<0.1$ \\
\hline 404718 & 775643 & PA19 & & D & 1.0 & $<2$ & $<0.5$ & 0.4 & 0.25 & $<1$ & 0.36 & $<3$ & $<10$ & 0.07 & 11 & 4.3 & $<0.1$ & $<0.1$ \\
\hline 431028 & 780108 & NY03 & & $p$ & 1.0 & 6 & $<0.5$ & 0.4 & 0.82 & 5 & 0.71 & $<3$ & $<10$ & 0.07 & 64 & 4.3 & $<0.1$ & 0.1 \\
\hline 423315 & 780435 & NX18 & & P & 1.0 & $<2$ & $<0.5$ & 0.4 & 0.50 & 1 & 0.77 & $<3$ & $<10$ & 0.11 & 61 & 4.1 & $<0.1$ & $<0.1$ \\
\hline 402043 & 780639 & PA12 & & $\mathbf{P}$ & $<0.1$ & $<2$ & $<0.5$ & 0.4 & 0.30 & 22 & 0.58 & $<3$ & $<10$ & 0.03 & 25 & 4.2 & $<0.1$ & $<0.1$ \\
\hline 414138 & 790322 & PA02 & & $\mathbf{P}$ & 1.0 & $<2$ & $<0.5$ & 0.4 & 0.29 & $<1$ & 0.37 & $<3$ & $<10$ & 0.08 & 40 & 4.0 & $<0.1$ & $<0.1$ \\
\hline 414138 & 790322 & PA23 & PA02 & $z$ & 1.0 & $<2$ & $<0.5$ & 0.4 & 0.36 & $<1$ & 0.54 & $<3$ & $<10$ & 0.12 & 33 & 4.0 & $<0.1$ & $<0.1$ \\
\hline 393621 & 790335 & MD07 & & $\mathbf{P}$ & $<0.1$ & 2 & $<0.5$ & 0.1 & 0.38 & 4 & 0.59 & $<3$ & $<10$ & 0.06 & 52 & 4.2 & $<0.1$ & 0.1 \\
\hline 401210 & 790500 & $\mathrm{PAO} 4$ & & $\mathbf{p}$ & 1.0 & 5 & $<0.5$ & 0.4 & 0.64 & $<1$ & 0.34 & $<3$ & $<10$ & 0.19 & 64 & 4.0 & $<0.1$ & $<0.1$ \\
\hline 405008 & 790640 & PA06 & & $\mathbf{P}$ & 2.0 & 2 & $<0.5$ & 0.4 & 0.71 & $<1$ & 2.10 & $<3$ & $<10$ & 0.12 & 66 & 3.9 & $<0.1$ & 0.1 \\
\hline 385754 & 792054 & WV02 & & $\mathbf{P}$ & 1.0 & 2 & $<0.5$ & 0.4 & 0.73 & $<1$ & 0.66 & $<3$ & $<10$ & 0.38 & 41 & 4.1 & $<0.1$ & 0.1 \\
\hline
\end{tabular}




\begin{tabular}{|c|c|c|c|c|c|c|c|c|c|c|c|c|c|c|c|c|c|c|}
\hline $\begin{array}{l}\text { Labora- } \\
\text { tory } \\
\text { Iden- } \\
\text { tifi- } \\
\text { cation } \\
\text { number }\end{array}$ & $\begin{array}{c} \\
\mathrm{LI} \\
\left(\mu_{\mathrm{g}} / \mathrm{L}\right)\end{array}$ & $\begin{array}{c}\mathrm{Mg} \\
(\mathrm{mg} / \mathrm{L})\end{array}$ & $\begin{array}{c}\mathrm{Mn} \\
(\mu \mathrm{g} / \mathrm{L})\end{array}$ & $\begin{array}{c}\text { Mo } \\
(\mu \mathrm{g} / \mathrm{L})\end{array}$ & $\begin{array}{l}\mathrm{NH}_{4}-\mathrm{N} \\
(\mathrm{mg} / \mathrm{L})\end{array}$ & $\begin{array}{r}\mathrm{NO}_{3}-\mathrm{N} \\
(\mathrm{mg} / \mathrm{L})\end{array}$ & $\begin{array}{c}\mathrm{Na} \\
(\mathrm{mg} / \mathrm{L})\end{array}$ & $\begin{array}{c}N i \\
(\mu \mathrm{g} / \mathrm{L})\end{array}$ & $\begin{array}{c}P b \\
(\mu g / L)\end{array}$ & $\begin{array}{c}\mathrm{Se} \\
(\mu \mathrm{g} / \mathrm{L})\end{array}$ & $\begin{array}{c}S i \\
(\mu g / L)\end{array}$ & $\begin{array}{c}\mathrm{SO}_{4} \\
(\mathrm{~m} / \mathrm{L})\end{array}$ & $\begin{array}{c}\mathrm{Sr} \\
(\mu \mathrm{g} / \mathrm{L})\end{array}$ & $\begin{array}{c}V \\
(\mu g / L)\end{array}$ & $\begin{array}{c}\mathrm{Zn} \\
(\mu \mathrm{g} / \mathrm{L})\end{array}$ & $\begin{array}{c}\text { Cations } \\
\text { sum } \\
\text { (meq/L) }\end{array}$ & 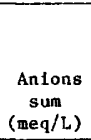 & $\begin{array}{c}\text { Specific } \\
\text { conductance } \\
(\mu \mathrm{mho} / \mathrm{cm} \\
\left(25^{\circ} \mathrm{C}\right)\end{array}$ \\
\hline NJO2 & 26 & 0.1 & 2 & $<10$ & 0.18 & 0.3 & 1.0 & $<1$ & 5 & $<0.1$ & 0.010 & 2.00 & 2.5 & $<6$ & 7 & 0.124 & 0.114 & 33.0 \\
\hline NJ04 & 24 & 0.1 & 2 & $<10$ & 0.11 & 0.4 & 1.1 & $<1$ & 5 & $<0.1$ & 0.090 & 2.40 & 3.2 & $<6$ & 6 & 0.136 & 0.129 & 26.0 \\
\hline NJ0SA & 45 & $<0.1$ & 4 & $<10$ & 0.29 & 0.6 & 0.4 & $<1$ & 10 & $<0.1$ & 0.057 & 2.00 & 2.6 & $<6$ & 20 & 0.113 & 0.103 & 26.0 \\
\hline NJ05B & 45 & 0.2 & 10 & $<10$ & 0.12 & 1.2 & 0.7 & $<1$ & 5 & $<0.1$ & 0.062 & 2.80 & 5.0 & $<6$ & 23 & 0.260 & 0.178 & 30.0 \\
\hline NJ05C & 44 & 0.1 & 1 & $<10$ & 0.07 & 0.3 & 1.0 & $<1$ & 3 & $<0.1$ & 0.310 & 2.00 & 4.5 & $<6$ & 5 & 0.191 & 0.114 & 16.0 \\
\hline $\mathrm{NJO}_{3}$ & 25 & 0.1 & 4 & $<10$ & 0.12 & 0.4 & 1.2 & $<i$ & 5 & $<0.1$ & 0.096 & 2.40 & 3.3 & $<6$ & 6 & 0.142 & 0.132 & 26.0 \\
\hline NY10 & 8 & 0.3 & 4 & $<10$ & 0.54 & 0.7 & 0.3 & 2 & 7 & $<0.1$ & 0.170 & 2.50 & 2.4 & $<6$ & 28 & 0.139 & 0.111 & 29.0 \\
\hline NY04 & 7 & 0.3 & 3 & $<10$ & 0.29 & 0.8 & 0.3 & $<1$ & 14 & $<0.1$ & 0.062 & 2.70 & 2.1 & $<6$ & 9 & 0.174 & 0.127 & 34.0 \\
\hline PA18 & $<4$ & $<0.1$ & 4 & $<10$ & 0.12 & 0.4 & 0.5 & 1 & 10 & $<0.1$ & 0.380 & 2.20 & 3.5 & $<6$ & 12 & 0.102 & 0.097 & 25.0 \\
\hline PA08 & 10 & $<0.1$ & 1 & $<10$ & 0.09 & 0.3 & 0.5 & 1 & 7 & $<0.1$ & 0.450 & 1.80 & 2.6 & $<6$ & $<3$ & 0.085 & 0.068 & 18.0 \\
\hline PA25 & 26 & $<0.1$ & 3 & $<10$ & 0.29 & 0.7 & 0.5 & 2 & 7 & $<0.1$ & 0.260 & 2.20 & 2.9 & $<6$ & 4 & 0.117 & 0.121 & 22.0 \\
\hline NY07 & 4 & 0.3 & 3 & $<10$ & 0.65 & 0.8 & 0.4 & $<1$ & 11 & $<0.1$ & 0.049 & 3.30 & 12.3 & $<6$ & 23 & 0.122 & 0.141 & 27.0 \\
\hline NYOI & 48 & 0.4 & 4 & $<10$ & 0.38 & 0.7 & 0.4 & $i$ & 16 & $<0.1$ & 0.450 & 1.90 & 4.0 & $<6$ & 11 & 0.158 & 0.097 & 19.0 \\
\hline NY17 & 12 & $<0.1$ & 2 & $<10$ & 0.21 & 0.5 & $<0.2$ & $<1$ & 9 & $<0.1$ & 0.600 & 1.40 & 3.4 & $<6$ & 6 & 0.075 & 0.071 & 31.0 \\
\hline PA07 & 12 & 0.1 & 7 & $<10$ & 0.23 & 0.5 & 1.2 & 1 & 7 & $<0.1$ & 0.320 & 2.90 & 4.6 & $<6$ & 11 & 0.172 & 0.124 & 30.0 \\
\hline NYO2 & 52 & 0.4 & 3 & $<10$ & 0.38 & 0.6 & 0.4 & $<1$ & 11 & $<0.1$ & 0.450 & 2.10 & 4.1 & $<6$ & 9 & 0.154 & 0.099 & 22.0 \\
\hline NY33 & 15 & $<0.1$ & 4 & $<10$ & 0.32 & 0.6 & 0.2 & 21 & 9 & $<0.1$ & 0.320 & 2.10 & 3.8 & $<6$ & 9 & 0.098 & 0.099 & 19.0 \\
\hline PALO & 5 & $<0.1$ & 8 & $<10$ & 0.17 & 0.4 & 0.2 & 2 & 4 & $<0.1$ & 0.110 & 2.00 & 2.9 & $<6$ & 192 & 0.097 & 0.075 & 19.0 \\
\hline NYI1 & 5 & 0.2 & 4 & $<10$ & 0.23 & 0.7 & 0.3 & $<1$ & 10 & $<0.1$ & 0.120 & 2.10 & 2.3 & $<6$ & 27 & 0.141 & 0.104 & 21.0 \\
\hline NY27 & $<4$ & $<0.1$ & 3 & $<10$ & 0.23 & 0.7 & 0.2 & $<1$ & 11 & $<0.1$ & 0.040 & 2.50 & $<0.5$ & $<6$ & 8 & 0.117 & 0.115 & 18.0 \\
\hline NY 22A & 11 & 0.1 & 12 & $<10$ & 1.80 & 1.7 & 0.3 & 1 & 28 & 1.0 & 0.130 & 5.10 & 5.7 & $<6$ & 57 & 0.194 & 0.255 & 46.0 \\
\hline NY22B & 12 & 0.1 & 4 & $<10$ & 0.13 & 0.8 & 0.3 & $<1$ & 9 & $<0.1$ & 0.010 & 1.90 & 2.2 & $<6$ & 6 & 0.128 & 0.119 & 22.0 \\
\hline NY 22C & 18 & 0.2 & 20 & $<10$ & 0.07 & 0.9 & 2.6 & 12 & 81 & $<0.1$ & 0.340 & 1.60 & 7.1 & $<6$ & 122 & 0.242 & 0.131 & 26.0 \\
\hline NY22D & 5 & 0.3 & 4 & $<10$ & 0.25 & 0.6 & 0.5 & 2 & 12 & $<0.1$ & 0.120 & 2.60 & 3.8 & $<6$ & 32 & 0.146 & 0.112 & 16.0 \\
\hline NY30 & $<4$ & $<0.1$ & 7 & $<10$ & 0.77 & 1.0 & 0.2 & 3 & 11 & $<0.1$ & 0.054 & 5.20 & 3.0 & $<6$ & 18 & 0.086 & 0.198 & 23.0 \\
\hline NY34 & 10 & $<0.1$ & 4 & $<10$ & 0.24 & 0.7 & 0.2 & 1 & 9 & $<0.1$ & 0.093 & 2.50 & 2.3 & $<6$ & 12 & 0.123 & 0.115 & 28.0 \\
\hline NY 36 & 21 & $<0.1$ & 5 & $<10$ & 0.15 & 0.7 & 0.3 & 1 & 5 & $<0.1$ & 0.071 & 1.70 & 2.5 & $<6$ & 7 & 0.124 & 0.108 & 24.0 \\
\hline NY15 & 11 & $<0.1$ & 4 & $<10$ & 0.25 & 0.8 & 0.4 & $<1$ & 4 & $<0.1$ & 0.130 & 2.20 & 2.8 & $<6$ & $<3$ & 0.121 & 0.120 & 14.0 \\
\hline PAl3 & 10 & $<0.1$ & 79 & $<10$ & 0.12 & 0.4 & 0.3 & 1 & 4 & $<0.1$ & 0.420 & 2.20 & 4.7 & $<6$ & $<3$ & 0.101 & 0.105 & 22.0 \\
\hline PA24 & 25 & $<0.1$ & 73 & $<10$ & 0.19 & 0.3 & 0.3 & 2 & 3 & $<0.1$ & 0.110 & 2.30 & 2.5 & $<6$ & 5 & 0.096 & 0.090 & 19.0 \\
\hline PA14 & 14 & $<0.1$ & 2 & $<10$ & 0.17 & 0.3 & 0.7 & 1 & 6 & $<0.1$ & 0.022 & 2.20 & 2.2 & $<6$ & $<3$ & 0.105 & 0.079 & 20.0 \\
\hline PA22 & 6 & $<0.1$ & 3 & $<10$ & 0.18 & 0.4 & 0.7 & $<1$ & 5 & $<0.1$ & 0.290 & 2.20 & 4.0 & $<6$ & 24 & 0.110 & 0.111 & 21.0 \\
\hline NY 12 & 12 & 0.2 & 5 & $<10$ & 0.21 & 0.8 & 0.2 & $<1$ & 12 & $<0.1$ & 0.170 & 2.40 & 3.7 & $<6$ & 12 & 0.123 & 0.114 & 16.0 \\
\hline PA09 & 5 & $<0.1$ & 2 & $<10$ & 0.11 & 0.3 & $<0.2$ & 1 & 6 & $<0.1$ & 0.320 & 1.60 & 3.2 & $<6$ & $<3$ & 0.097 & 0.065 & 24.0 \\
\hline PA21 & 7 & $<0.1$ & $<1$ & $<10$ & 0.16 & 0.5 & $<0.2$ & 1 & 4 & $<0.1$ & 0.560 & 2.50 & 3.4 & $<6$ & $<3$ & 0,102 & 0.096 & 24.0 \\
\hline PA15 & 11 & $<0.1$ & 2 & $<10$ & 0.17 & 0.5 & 0.2 & 1 & 7 & $<0.1$ & 0.031 & 2.70 & 1.7 & $<6$ & $<3$ & 0.117 & 0.097 & 26.0 \\
\hline PAll & 4 & $<0.1$ & $i$ & $<10$ & 0.09 & 0.2 & $<0.2$ & $<1$ & 3 & $<0.1$ & 0.330 & 1.40 & 3.2 & $<6$ & $<3$ & 0.054 & 0.061 & 9.6 \\
\hline PA16 & 7 & $<0.1$ & 1 & $<10$ & 0.10 & 0.1 & $<0.2$ & $<1$ & 6 & $<0.1$ & 0.220 & 0.82 & 2.1 & $<6$ & $<3$ & 0.036 & 0.032 & 5.5 \\
\hline PA20 & 9 & $<0.1$ & 2 & $<10$ & 0.33 & 0.6 & $<0.2$ & 2 & 10 & $<0.1$ & 0.560 & 1.50 & 3.5 & $<6$ & 8 & 0.056 & 0.091 & 25.0 \\
\hline PA17 & 12 & $<0.1$ & $<1$ & $<10$ & 0.14 & 0.2 & $<0.2$ & $<1$ & 4 & $<0.1$ & 0.170 & 1.10 & 2.2 & $<6$ & $<3$ & 0.041 & 0.044 & 22.0 \\
\hline PA19 & 9 & $<0.1$ & 3 & $<10$ & 0.08 & 0.2 & 0.2 & 1 & 4 & $<0.1$ & 0.570 & 1.70 & 3.1 & $<6$ & $<3$ & 0.077 & 0.060 & 13.0 \\
\hline NY03 & 52 & 0.5 & 9 & $<10$ & 0.57 & 1.0 & 0.6 & $<1$ & 10 & $<0.1$ & 0.530 & 3.30 & 6.5 & $<6$ & 27 & 0.199 & 0.160 & 29.0 \\
\hline NY18 & 10 & 0.1 & 9 & $<10$ & 0.33 & 0.9 & 0.3 & $<1$ & 16 & $<0.1$ & 0.025 & 3.00 & 2.5 & $<6$ & 43 & 0.149 & 0.148 & 20.0 \\
\hline PA12 & 7 & 0.1 & 3 & $<10$ & 0.16 & 0.5 & 0.3 & $i$ & 7 & $<0.1$ & 0.012 & 2.60 & 1.3 & $<6$ & 8 & 0.111 & 0.106 & 22.0 \\
\hline PAO2 & $<4$ & $<0.1$ & 6 & $<10$ & 0.28 & 0.7 & $<0.2$ & 1 & 12 & $<0.1$ & 0.140 & 3.00 & 2.9 & $<6$ & 10 & 0.134 & 0.123 & 34.0 \\
\hline PA23 & 10 & $<0.1$ & 4 & $<10$ & 0.28 & 0.7 & $<0.2$ & 2 & 10 & $<0.1$ & 0.600 & 3.10 & 5.4 & $<6$ & 5 & 0.138 & 0.130 & 32.0 \\
\hline MD07 & 9 & $<0.1$ & 7 & $<10$ & 0.46 & 0.6 & 0.3 & 1 & 10 & $<0.1$ & 0.220 & 3.70 & 2.0 & $<6$ & 23 & 0.128 & 0.136 & 34.0 \\
\hline PAO4 & 5 & $<0.1$ & 75 & $<10$ & 0.29 & 0.9 & 0.2 & 2 & 9 & $<0.1$ & 0.400 & 3.80 & 4.9 & $<6$ & 23 & 0.161 & 0.153 & 38.0 \\
\hline PAO6 & 10 & 0.1 & 9 & $<10$ & 0.27 & 0.8 & 0.2 & 3 & 15 & $<0.1$ & 0.510 & 0.49 & 5.9 & $<6$ & 14 & 0.198 & 0.127 & 44.0 \\
\hline WVO2 & 29 & $<0.1$ & 9 & $<10$ & 0.34 & 0.8 & 0.3 & $<1$ & 11 & $<0.1$ & 0.290 & 4.60 & 5.1 & $<6$ & 28 & 0.153 & 0.171 & 36.0 \\
\hline
\end{tabular}


TABLE 5. - Dissolved chemical constituent

\begin{tabular}{|c|c|c|c|c|c|c|c|c|c|c|c|c|c|c|c|c|c|c|}
\hline $\begin{array}{l}\text { Lat 1- } \\
\text { tude }\end{array}$ & $\begin{array}{l}\text { Long1- } \\
\text { tude }\end{array}$ & $\begin{array}{l}\text { Labora- } \\
\text { tory } \\
\text { iden- } \\
\text { tifi- } \\
\text { cation } \\
\text { number }\end{array}$ & $\begin{array}{l}\text { Split } \\
\text { sample } \\
\text { Iden } \\
\text { tifi- } \\
\text { cation } \\
\text { number }\end{array}$ & $\begin{array}{c}\text { Sample } \\
\text { type }\end{array}$ & $\begin{array}{c}\text { As } \\
(\mu \mathrm{g} / \mathrm{L})\end{array}$ & $\begin{array}{c}\mathrm{Ba} \\
(\mu \mathrm{g} / \mathrm{L})\end{array}$ & $\begin{array}{c}\mathrm{Be} \\
(\mu \mathrm{g} / \mathrm{L})\end{array}$ & $\begin{array}{c}\text { Total } \\
\text { Inorganic } \\
\text { carbon } \\
(\mathrm{mg} / \mathrm{L})\end{array}$ & $\begin{array}{c}\mathrm{Ca} \\
(\mathrm{mg} / \mathrm{L})\end{array}$ & $\begin{array}{c}C d \\
(\mu g / L)\end{array}$ & $\begin{array}{c}\mathrm{Cl} \\
(\mathrm{mg} / \mathrm{L})\end{array}$ & $\begin{array}{c}\text { Co } \\
(\mu \mathrm{g} / \mathrm{L})\end{array}$ & $\begin{array}{c}\mathrm{Cu} \\
(\mu \mathrm{g} / \mathrm{L})\end{array}$ & $\underset{(\mathrm{mg} / \mathrm{L})}{\mathrm{F}}$ & $\begin{array}{c}\mathrm{Fe} \\
(\mu \mathrm{g} / \mathrm{L})\end{array}$ & $\begin{array}{c}\mathrm{pH} \\
(\mu \mathrm{g} / \mathrm{L})\end{array}$ & $\begin{array}{c}\mathrm{Hg} \\
\left(\mu_{\mathrm{g}} / \mathrm{L}\right)\end{array}$ & $\underset{(\mathrm{mg} / \mathrm{L})}{\mathrm{K}}$ \\
\hline 421835 & 792408 & NX08 & & P & 1.0 & $<2$ & $<0.5$ & 0.4 & 0.32 & $<1$ & 0.40 & $<3$ & $<10$ & 0.03 & 35 & 4.1 & $<0.1$ & $<0.1$ \\
\hline 392630 & 792704 & MD05 & & $\mathrm{P}$ & $<0.1$ & 2 & $<0.5$ & 0.2 & 0.24 & 79 & 0.31 & $<3$ & 40 & 0.08 & 35 & 4.4 & $<0.1$ & $<0.1$ \\
\hline 392630 & 792704 & MD06 & & $\mathbf{R}$ & - & 3 & $<0.5$ & 0.1 & 0.67 & 10 & 1.10 & $<3$ & 10 & 0.19 & 48 & 4.3 & 0.1 & 0.4 \\
\hline 392630 & 792704 & $\mathrm{MDOl}$ & & A & $<0.1$ & 6 & $<0.5$ & 0.2 & 0.54 & 8 & 0.47 & $<3$ & 10 & 0.06 & 60 & 4.4 & $<0.1$ & 0.1 \\
\hline 392630 & 792704 & MDO2 & & B & 1.0 & 3 & $<0.5$ & 0.2 & 0.62 & $<1$ & 0.56 & $<3$ & $<10$ & 0.06 & 56 & 4.3 & $<0.1$ & 0.1 \\
\hline 392630 & 792704 & MD04 & & $c$ & 1.0 & 4 & $<0.5$ & 0.1 & 0.91 & $<1$ & 0.62 & $<3$ & $<10$ & 0.08 & 127 & 4.9 & $<0.1$ & 0.4 \\
\hline 392630 & 792704 & $\mathrm{MDO3}$ & & D & $<0.1$ & $<2$ & $<0.5$ & 0.1 & 0.28 & 8 & 0.38 & $<3$ & 20 & 0.05 & 40 & 4.5 & $<0.1$ & $<0.1$ \\
\hline 384123 & 793230 & WV05 & & $P$ & 1.0 & 2 & $<0.5$ & 0.4 & 0.72 & $<1$ & 0.56 & $<3$ & $<10$ & 0.07 & 50 & 3.9 & $<0.1$ & 0.1 \\
\hline 385619 & 794316 & WV03 & & $\mathbf{P}$ & $<0.1$ & $<2$ & $<0.5$ & 0.4 & 0.14 & $<1$ & 0.34 & $<3$ & $<10$ & 0.08 & 10 & 4.7 & $<0.1$ & 0.1 \\
\hline 410506 & 795327 & $\mathrm{PA} 03$ & & P & 1.0 & 3 & $<0.5$ & 0.4 & 0.31 & $<1$ & 1.60 & $<3$ & $<10$ & 0.08 & 47 & 4.3 & $<0.1$ & $<0.1$ \\
\hline 384024 & 795348 & WVO1 & & $\mathbf{P}$ & $<0.1$ & $<2$ & $<0.5$ & 0.4 & 0.43 & $<1$ & 0.32 & $<3$ & $<10$ & 0.06 & 16 & 4.2 & $<0.1$ & $<0.1$ \\
\hline 384024 & 795348 & Wv06A & & B & $<0.1$ & $<2$ & $<0.5$ & 0.4 & 0.12 & $<1$ & 0.29 & $<3$ & $<10$ & 0.02 & 10 & 4.5 & $<0.1$ & $<0.1$ \\
\hline 384024 & 795348 & WV06B & & C & $<0.1$ & $<2$ & $<0.5$ & 0.4 & 0.30 & $<1$ & 0.52 & $<3$ & $<10$ & 0.04 & 14 & 5.1 & $<0.1$ & $<0.1$ \\
\hline 384024 & 795348 & wV06C & & D & $<0.1$ & $<2$ & $<0.5$ & 0.4 & 0.45 & $<1$ & 0.29 & $<3$ & $<10$ & 0.03 & 17 & 4.1 & $<0.1$ & 0.1 \\
\hline 382256 & 800503 & WV04 & & $\mathbf{P}$ & $<0.1$ & $<2$ & $<0.5$ & 0.4 & 0.50 & $<1$ & 0.73 & $<3$ & $<10$ & 0.12 & 46 & 3.9 & $<0.1$ & 0.1 \\
\hline 394935 & 802100 & PA05 & & $\mathrm{P}$ & 1.0 & 2 & $<0.5$ & 0.4 & 0.42 & $<1$ & 0.79 & $<3$ & $<10$ & 0.07 & 56 & 4.0 & $<0.1$ & 0.1 \\
\hline 414444 & 802715 & PAOLA & & $\mathbf{P}$ & 1.0 & 3 & $<0.5$ & 0.4 & 0.38 & $<1$ & 0.36 & 3 & $<10$ & 0.07 & 52 & 4.0 & $<0.1$ & $<0.1$ \\
\hline 414444 & 802715 & PAO1B & & $\mathbf{R}$ & 1.0 & $<2$ & $<0.5$ & 0.4 & 0.54 & $<1$ & 0.36 & $<3$ & $<10$ & 0.05 & 35 & 3.8 & $<0.1$ & $<0.1$ \\
\hline 413446 & 803206 & OI 14 & & $\mathrm{P}$ & 1.0 & 2 & $<0.5$ & 0.4 & 0.60 & $<1$ & 0.59 & $<3$ & $<10$ & 0.09 & 65 & 4.0 & $<0.1$ & 0.1 \\
\hline 404800 & 805208 & or 10 & & $\mathbf{P}$ & 1.0 & 2 & $<0.5$ & 0.6 & 0.55 & $<1$ & 0.40 & $<3$ & $<10$ & 0.08 & 80 & 4.0 & $<0.1$ & 0.1 \\
\hline 412839 & 805327 & or 13 & & P & 1.0 & $<2$ & $<0.5$ & 0.4 & 0.65 & $<1$ & 0.86 & $<3$ & $<10$ & 0.14 & 77 & 4.0 & $<0.1$ & 0.1 \\
\hline 413629 & 805803 & 0I 16 & & P & $<0.1$ & $<2$ & $<0.5$ & 0.4 & 0.61 & $<1$ & 0.74 & $<3$ & $<10$ & 0.11 & 62 & 4.1 & $<0.1$ & 0.1 \\
\hline 415128 & 805822 & oI 18 & & P & $<0.1$ & 2 & $<0.5$ & 0.4 & 0.80 & $<1$ & 0.40 & 3 & $<10$ & 0.09 & 83 & 4.0 & $<0.1$ & 0.1 \\
\hline 415128 & 805822 & OI 19 & & $\mathrm{R}$ & 1.0 & 2 & $<0.5$ & 0.4 & 0.84 & $<1$ & 1.70 & $<3$ & $<10$ & 0.27 & 97 & 4.2 & $<0.1$ & 0.1 \\
\hline 415128 & 805822 & oI $17 \mathrm{~A}$ & & A & $<0.1$ & 2 & $<0.5$ & 0.4 & 1.00 & $<1$ & 1.10 & $<3$ & $<10$ & 0.06 & 64 & 5.4 & $<0.1$ & 0.5 \\
\hline 415128 & 805822 & oI $17 \mathrm{~B}$ & & B & 1.0 & 2 & $<0.5$ & 0.4 & 0.67 & $<1$ & 1.10 & $<3$ & $<10$ & 0.06 & 87 & 4.0 & $<0.1$ & 0.1 \\
\hline 415128 & 805822 & or $17 \mathrm{C}$ & & C & 1.0 & 3 & $<0.5$ & 0.4 & 1.40 & $<1$ & 0.60 & $<3$ & $<10$ & 0.08 & 92 & 4.0 & $<0.1$ & 0.1 \\
\hline 415128 & 805822 & oI 170 & & D & $<0.1$ & $<2$ & $<0.5$ & 0.4 & 0.43 & $<1$ & 0.50 & 4 & $<10$ & 0.10 & 35 & 4.0 & $<0.1$ & $<0.1$ \\
\hline 415128 & 805822 & or 22 & or 18 & $z$ & 1.0 & $<2$ & $<0.5$ & 0.4 & 0.65 & $<1$ & 0.62 & $<3$ & $<10$ & 0.08 & 58 & 4.6 & $<0.1$ & $<0.1$ \\
\hline 411233 & 810713 & oI11 & & $P$ & 1.0 & $<2$ & $<0.5$ & 0.6 & 0.67 & $<1$ & 0.85 & $<3$ & $<10$ & 0.18 & 61 & 4.0 & $<0.1$ & 0.1 \\
\hline 413256 & 811613 & $0 \mathrm{O} 15$ & & $\mathbf{P}$ & 1.0 & 2 & $<0.5$ & 0.4 & 0.75 & $<1$ & 0.87 & $<3$ & $<10$ & 0.07 & 101 & 4.1 & $<0.1$ & $<0.1$ \\
\hline 413256 & 811613 & OI 20 & OI 15 & $z$ & $<0.1$ & $<2$ & $<0.5$ & 0.4 & 0.78 & $<1$ & 1.10 & 5 & $<10$ & 0.10 & 69 & 4.5 & $<0.1$ & $<0.1$ \\
\hline 411530 & 815542 & 0103 & & $\mathbf{p}$ & 1.0 & 2 & $<0.5$ & 3.1 & 0.98 & $<1$ & 0.84 & $<3$ & $<10$ & 0.08 & 60 & 6.8 & $<0.1$ & 1.0 \\
\hline 405152 & 815631 & OI 12 & & $\mathbf{P}$ & $<0.1$ & $<2$ & $<0.5$ & 0.4 & 0.60 & $<1$ & 0.84 & 3 & $<10$ & 0.08 & 68 & 4.2 & $<0.1$ & 0.1 \\
\hline 405152 & 815631 & OI 24 & of 12 & $\mathbf{z}$ & 3.0 & $<2$ & $<0.5$ & 0.4 & 0.59 & $<1$ & 0.43 & $<3$ & $<10$ & 0.05 & 44 & 7.2 & $<0.1$ & $<0.1$ \\
\hline 402351 & 821658 & OI 01 & & p & $<0.1$ & $<2$ & $<0.5$ & 0.8 & 0.35 & $<1$ & 0.22 & $<3$ & $<10$ & 0.11 & 22 & 4.3 & $<0.1$ & $<0.1$ \\
\hline 405743 & 824716 & OI09 & & $\mathbf{P}$ & $<0.1$ & 2 & $<0.5$ & 0.6 & 0.92 & $<1$ & 0.65 & $<3$ & $<10$ & 0.09 & 62 & 4.2 & $<0.1$ & 0.1 \\
\hline 405743 & 824716 & OI 08 & & R & $<0.1$ & 2 & $<0.5$ & 0.8 & 1.10 & $<1$ & 0.52 & $<3$ & 10 & 0.10 & 54 & 4.3 & $<0.1$ & 0.1 \\
\hline 405743 & 824716 & OI 23 & or 09 & $Z$ & 5.0 & $<2$ & $<0.5$ & 0.4 & 0.67 & $<1$ & 0.59 & $<3$ & $<10$ & 0.07 & 39 & 4.7 & $<0.1$ & 0.1 \\
\hline 413232 & 824852 & oros & & p & 1.0 & $<2$ & $<0.5$ & 0.8 & 1.50 & $<1$ & 0.77 & $<3$ & $<10$ & 0.06 & 32 & 4.6 & $<0.1$ & 0.1 \\
\hline 403257 & 824906 & OI06 & & p & $<0.1$ & $<2$ & $<0.5$ & 0.4 & 0.73 & 10 & 0.45 & 3 & 10 & 0.07 & 32 & - & $<0.1$ & $<0.1$ \\
\hline 425953 & 831058 & MI07 & & $\mathrm{P}$ & 1.0 & 2 & $<0.5$ & 0.4 & 0.60 & 5 & 0.54 & $<3$ & 10 & 0.09 & 37 & 4.5 & $<0.1$ & 0.2 \\
\hline 434549 & 831446 & MI 19 & & P & 1.0 & 5 & $<0.5$ & 1.8 & 4.00 & 8 & 0.81 & $<3$ & 10 & 0.08 & 10 & 6.6 & $<0.1$ & 0.1 \\
\hline 403048 & 831545 & 0107 & & $P$ & $<0.1$ & 2 & $<0.5$ & 0.4 & 1.40 & $<1$ & 0.91 & $<3$ & $<10$ & 0.07 & 60 & 4.3 & 0.3 & 0.1 \\
\hline 450829 & 833610 & MI 16 & & P & 1.0 & 2 & $<0.5$ & 0.4 & 0.86 & $<1$ & 0.29 & $<3$ & $<10$ & 0.08 & 50 & 4.3 & $<0.1$ & 0.1 \\
\hline 443212 & 834322 & MI 17 & & p & $<0.1$ & 2 & $<0.5$ & 0.4 & 0.51 & $<1$ & 0.42 & $<3$ & $<10$ & 0.10 & 31 & 4.2 & $<0.1$ & 0.1 \\
\hline 411254 & 834551 & OI02 & & P & $<0.1$ & 2 & $<0.5$ & 0.4 & 0.88 & $<1$ & 0.40 & $<3$ & $<10$ & 0.05 & 48 & 4.2 & $<0.1$ & 0.1 \\
\hline 413838 & 842141 & OI 04 & & P & $<0.1$ & 2 & $<0.5$ & 0.2 & 0.86 & $<1$ & 0.37 & $<3$ & $<10$ & 0.06 & 128 & 4.6 & $<0.1$ & 0.1 \\
\hline 413838 & 842141 & oI 21 & Or 04 & $z$ & $<0.1$ & $<2$ & $<0.5$ & 0.4 & 0.46 & $<1$ & 0.36 & $<3$ & $<10$ & 0.14 & 33 & 5.5 & $<0.1$ & $<0.1$ \\
\hline 435243 & 842818 & MI 18 & & $\mathbf{P}$ & 1.0 & 2 & $<0.5$ & 0.4 & 1.20 & 19 & 0.55 & $<3$ & $<10$ & 0.09 & 33 & 4.4 & $<0.1$ & 0.4 \\
\hline
\end{tabular}




\begin{tabular}{|c|c|c|c|c|c|c|c|c|c|c|c|c|c|c|c|c|c|c|}
\hline $\begin{array}{l}\text { Labora- } \\
\text { tory } \\
\text { Iden- } \\
\text { tifi- } \\
\text { cation } \\
\text { number }\end{array}$ & $\begin{array}{c} \\
\mathrm{Li} \\
(\mu \mathrm{g} / \mathrm{L})\end{array}$ & $\underset{(\mathrm{mg} / \mathrm{L})}{\mathrm{Mg}}$ & $\begin{array}{c}\mathrm{Mn} \\
(\mu \mathrm{g} / \mathrm{L})\end{array}$ & $\begin{array}{c}\text { Mo } \\
(\mu \mathrm{g} / \mathrm{L})\end{array}$ & $\begin{array}{l}\mathrm{NH}_{4}-\mathrm{N} \\
(\mathrm{mg} / \mathrm{L})\end{array}$ & $\begin{array}{c}\mathrm{NO}_{3}-\mathrm{N} \\
(\mathrm{mg} / \mathrm{L})\end{array}$ & $\begin{array}{c}\mathrm{Na} \\
(\mathrm{mg} / \mathrm{L})\end{array}$ & $\begin{array}{c}\mathrm{Ni} \\
(\mu \mathrm{g} / \mathrm{L})\end{array}$ & $\begin{array}{c}\mathrm{Pb} \\
(\mu \mathrm{g} / \mathrm{L})\end{array}$ & $\begin{array}{c}\mathrm{Se} \\
(\mu \mathrm{g} / \mathrm{L})\end{array}$ & $\begin{array}{c}S i \\
(\mu g / L)\end{array}$ & $\begin{array}{c}\mathrm{SO}_{4} \\
(\mathrm{~m} / \mathrm{L})\end{array}$ & $\begin{array}{c}\mathrm{Sr} \\
(\mu \mathrm{gg} / \mathrm{L})\end{array}$ & $\begin{array}{c}V \\
(\mu g / L)\end{array}$ & $\begin{array}{c}\mathrm{Zn} \\
(\mu \mathrm{g} / \mathrm{L})\end{array}$ & $\begin{array}{l}\text { Cations } \\
\text { sum } \\
\text { (meq/L) }\end{array}$ & $\begin{array}{l}\text { Anlons } \\
\text { sum } \\
(\mathrm{meq} / \mathrm{L})\end{array}$ & $\begin{array}{l}\text { Specif tc } \\
\text { conductance } \\
(\mu \mathrm{mho} / \mathrm{cm} \\
\left(225^{\circ} \mathrm{C}\right)\end{array}$ \\
\hline NY08 & 7 & 0.3 & 4 & $<10$ & 0.25 & 0.7 & 0.3 & $<1$ & 11 & $<0.1$ & 0.045 & 2.70 & 2.1 & $<6$ & $<3$ & 0.151 & 0.117 & 9.6 \\
\hline MD05 & 6 & $<0.1$ & 6 & $<10$ & 0.25 & 0.3 & 0.4 & 2 & 9 & $<0.1$ & 0.210 & 2.60 & 1.4 & $<6$ & 91 & 0.087 & 0.084 & 22.0 \\
\hline MD06 & 7 & 0.1 & 8 & $<10$ & 0.50 & 0.6 & 0.3 & 1 & 10 & $<0.1$ & 0.670 & 4.20 & 2.5 & $<6$ & 113 & 0.141 & 0.161 & . \\
\hline MD01 & 10 & $<0.1$ & 7 & $<10$ & 0.45 & 0.6 & 0.2 & 2 & 12 & $<0.1$ & 0.078 & 3.30 & 1.4 & $<6$ & 52 & 0.108 & 0.125 & 25.0 \\
\hline MDO2 & $<4$ & $<0.1$ & 12 & $<10$ & 0.48 & 0.7 & $<0.2$ & 1 & 9 & $<0.1$ & 0.110 & 3.00 & 0.6 & $<6$ & 18 & 0.115 & 0.128 & 29.0 \\
\hline MD04 & $<4$ & $<0.1$ & 16 & $<10$ & 0.37 & 1.0 & 0.3 & 1 & 10 & $<0.1$ & 0.150 & 2.40 & 3.0 & $<6$ & 44 & 0.097 & 0.139 & 35.0 \\
\hline MD03 & 4 & $<0.1$ & 6 & $<10$ & 0.32 & 0.4 & $<0.2$ & $<i$ & 7 & $<0.1$ & 0.054 & 3.00 & 1.2 & $<6$ & 12 & 0.068 & 0.102 & 28.0 \\
\hline WV05 & 24 & $<0.1$ & 9 & $<10$ & 0.60 & 0.9 & 0.4 & 1 & 24 & $<0.1$ & 0.098 & 6.60 & 3.4 & $<6$ & 184 & 0.222 & 0.217 & 60.0 \\
\hline WV03 & 26 & $<0.1$ & 2 & $<10$ & 0.06 & 0.1 & $<0.2$ & i & 2 & $<0.1$ & 0.200 & 0.99 & 2.9 & $<6$ & 17 & 0.031 & 0.037 & 5.6 \\
\hline PA03 & $<4$ & $<0.1$ & 6 & $<10$ & 0.20 & 0.5 & $<0.2$ & 2 & 10 & $<0.1$ & 0.330 & 2.90 & 3.5 & $<6$ & 592 & 0.080 & 0.141 & 17.0 \\
\hline wV01 & 26 & $<0.1$ & 10 & $<10$ & 0.22 & 0.6 & 0.3 & $<1$ & 3 & $<0.1$ & 0.260 & 2.50 & 3.7 & $<6$ & 18 & 0.113 & 0.104 & 25.0 \\
\hline WV06A & 36 & $<0.1$ & 2 & $<10$ & 0.20 & 0.4 & $<0.2$ & 1 & $<1$ & $<0.1$ & 0.310 & 1.10 & 2.3 & $<6$ & $<3$ & 0.052 & 0.060 & 7.0 \\
\hline WV06B & 31 & $<0.1$ & 2 & $<10$ & 0.17 & 0.3 & $<0.2$ & $<1$ & 1 & $<0.1$ & 0.520 & 0.71 & 4.5 & $<6$ & $<3$ & 0.035 & 0.051 & 6.0 \\
\hline WN06C & 32 & 0.1 & 6 & $<10$ & 0.18 & 0.5 & 0.3 & $<1$ & 2 & $<0.1$ & 0.430 & 2.30 & 5.9 & $<6$ & 20 & 0.136 & 0.092 & 16.0 \\
\hline WV0 4 & 24 & $<0.1$ & 7 & $<10$ & 0.25 & 0.9 & 0.2 & 1 & 11 & $<0.1$ & 0.640 & 3.30 & 6.6 & $<6$ & 18 & 0.177 & 0.153 & 45.0 \\
\hline PA05 & 4 & $<0.1$ & 8 & $<10$ & 0.25 & 0.6 & $<0.2$ & 2 & 9 & $<0.1$ & 0.200 & 4.00 & 3.2 & $<6$ & 13 & 0.139 & 0.148 & 37.0 \\
\hline PA0IA & $<4$ & $<0.1$ & 7 & $<10$ & 0.36 & 0.7 & $<0.2$ & 3 & 12 & $<0.1$ & 0.160 & 3.50 & 3.6 & $<6$ & 17 & 0.145 & 0.133 & 35.0 \\
\hline PAOIB & $<4$ & $<0.1$ & 6 & $<10$ & 0.20 & 0.4 & $<0.2$ & 2 & 8 & $<0.1$ & 0.410 & 2.40 & 4.0 & $<6$ & 15 & 0.200 & 0.089 & 19.0 \\
\hline OI 14 & 15 & 0.1 & 8 & $<10$ & 0.34 & 0.8 & 0.3 & 6 & 12 & $<0.1$ & 0.600 & 3.50 & 6.3 & $<6$ & 22 & 0.175 & 0.146 & 34.0 \\
\hline OI 10 & 4 & $<0.1$ & 10 & $<10$ & 0.26 & 0.7 & 0.2 & 1 & 11 & $<0.1$ & 0.600 & 3.70 & 4.6 & $<6$ & 15 & 0.155 & 0.138 & 32.0 \\
\hline JI 13 & 9 & 0.1 & 10 & $<10$ & 0.35 & 0.8 & 0.3 & 34 & 15 & $<0.1$ & 0.680 & 3.50 & 6.5 & $<6$ & 17 & 0.179 & 0.154 & 36.0 \\
\hline II 16 & 19 & 0.1 & 9 & $<10$ & 0.32 & 0.7 & 0.4 & 2 & 14 & $<0.1$ & 0.220 & 3.70 & 4.1 & $<6$ & 14 & 0.158 & 0.148 & 34.0 \\
\hline OT 18 & 22 & $<0.1$ & 9 & $<10$ & 0.30 & 0.9 & 0.3 & 2 & 16 & $<0.1$ & 0.290 & 2.80 & 4.5 & $<6$ & 19 & 0.174 & 0.134 & 19.0 \\
\hline OI 19 & 20 & $<0.1$ & 9 & $<10$ & 0.32 & 0.9 & 0.3 & 2 & 16 & $<0.1$ & 0.800 & 5.90 & 7.4 & $<6$ & 18 & 0.141 & 0.235 & 42.0 \\
\hline $0 I 17 \mathrm{~A}$ & 15 & 0.1 & 9 & $<10$ & 0.41 & 0.6 & 0.8 & 6 & 19 & $<0.1$ & 0.480 & 2.80 & 6.0 & $<6$ & 49 & 0.126 & 0.132 & 15.0 \\
\hline OI $17 \mathrm{~B}$ & 17 & 0.1 & 8 & $<10$ & 0.27 & 1.0 & 0.7 & 2 & 24 & $<0.1$ & 0.220 & 3.40 & 4.1 & $<6$ & 24 & 0.191 & 0.173 & 35.0 \\
\hline of $17 \mathrm{C}$ & 20 & 0.1 & 15 & $<10$ & 0.47 & 1.2 & 0.4 & 2 & 26 & $<0.1$ & 0.510 & 4.50 & 6.3 & $<6$ & 60 & 0.229 & 0.196 & 41.0 \\
\hline 01170 & 18 & 0.1 & 6 & $<10$ & 0.24 & 0.8 & 0.2 & 2 & 11 & $<0.1$ & 0.150 & 3.50 & 2.9 & 6 & 11 & 0.156 & 0.144 & 33.0 \\
\hline OI 22 & 25 & $<0.1$ & 7 & $<10$ & 0.29 & 0.9 & 0.3 & 2 & 13 & $<0.1$ & 0.180 & 3.50 & 3.9 & $<6$ & 17 & 0.091 & 0.154 & 36.0 \\
\hline OI11 & 12 & 0.1 & 8 & $<10$ & 0.28 & 0.8 & 0.4 & $<1$ & 16 & $<0.1$ & 0.630 & 3.60 & 6.6 & $<6$ & 16 & 0.179 & 0.156 & 39.0 \\
\hline OI 15 & 13 & 0.2 & 12 & $<10$ & 0.34 & 0.8 & 0.5 & 2 & 19 & $<0.1$ & 0.280 & 3.90 & 4.7 & $<6$ & 27 & 0.179 & 0.163 & 36.0 \\
\hline OI 20 & 26 & $<0.1$ & 11 & $<10$ & 0.33 & 0.8 & 0.4 & 1 & 15 & $<0.1$ & 0.640 & 4.30 & 7.6 & $<6$ & 26 & 0.112 & 0.177 & 34.0 \\
\hline 0103 & 9 & 0.2 & 12 & $<10$ & 2.70 & 0.7 & 0.6 & 3 & 27 & $<0.1$ & 0.540 & 4.40 & 4.6 & $<6$ & 7 & 0.284 & 0.165 & 42.0 \\
\hline oI 12 & 17 & 0.1 & 7 & $<10$ & 0.73 & 0.8 & 0.3 & 7 & 7 & $<0.1$ & 0.770 & 3.70 & 7.2 & $<6$ & 13 & 0.166 & 0.158 & 30.0 \\
\hline OI 24 & 22 & 0.1 & 6 & $<10$ & 0.72 & 0.8 & 0.3 & 2 & 10 & $<0.1$ & 0.260 & 3.90 & 4.0 & $<6$ & 14 & 0.102 & 0.150 & 30.0 \\
\hline orol & 10 & 0.1 & 3 & $<10$ & 0.20 & 0.4 & $<0.2$ & 1 & 5 & $<0.1$ & 0.830 & 2.20 & 4.0 & $<6$ & $<3$ & 0.090 & 0.080 & 15.0 \\
\hline 0109 & 5 & 0.1 & 5 & $<10$ & 0.45 & 1.0 & 0.2 & $<1$ & 6 & $<0.1$ & 0.620 & 4.30 & 4.7 & $<6$ & 8 & 0.158 & 0.179 & 33.0 \\
\hline 0108 & 4 & 0.3 & 7 & $<10$ & 0.60 & 0.7 & 0.5 & 1 & 12 & $<0.1$ & 0.530 & 4.00 & 5.3 & $<6$ & 22 & 0.194 & 0.148 & 19.0 \\
\hline OI 23 & 26 & 0.1 & 5 & $<10$ & 0.46 & 1.0 & 0.2 & 2 & 19 & $<0.1$ & 0.140 & 4.10 & 3.0 & $<6$ & 7 & 0.103 & 0.173 & 32.0 \\
\hline OL05 & 10 & 0.4 & 7 & $<10$ & 0.37 & 0.9 & 0.5 & l & 9 & $<0.1$ & 0.530 & 4.60 & 6.7 & $<6$ & $<3$ & 0.181 & 0.182 & 23.0 \\
\hline OTO6 & 6 & 0.2 & 3 & $<10$ & 0.26 & 0.6 & 0.2 & $<1$ & 9 & $<0.1$ & 0.620 & 2.80 & 4.3 & $<6$ & 13 & 0.080 & 0.114 & 18.0 \\
\hline MI07 & $<4$ & 0.1 & 5 & $<10$ & 0.50 & 0.6 & 0.2 & 5 & 9 & $<0.1$ & 0.084 & 3.00 & 1.5 & $<6$ & 16 & 0.114 & 0.120 & 22.0 \\
\hline MI 19 & $<4$ & 0.8 & 19 & $<10$ & 0.82 & 1.4 & 0.3 & 1 & 1 & $<0.1$ & 0.110 & 3.40 & 5.1 & $<6$ & 21 & 0.337 & 0.193 & 44.0 \\
\hline 0107 & 4 & 0.3 & 7 & $<10$ & 0.66 & 1.1 & 0.6 & 3 & 14 & $<0.1$ & 0.580 & 5.10 & 5.4 & $<6$ & 21 & 0.218 & 0.210 & 34.0 \\
\hline MI 16 & 6 & $<0.1$ & 8 & $<10$ & 0.23 & 0.6 & $<0.2$ & $<1$ & 8 & $<0.1$ & 0.270 & 2.50 & 3.4 & $<6$ & 10 & 0.109 & 0.103 & 25.0 \\
\hline MI 17 & 4 & $<0.1$ & 4 & $<10$ & 0.51 & 0.7 & $<0.2$ & 2 & 14 & $<0.1$ & 0.300 & 2.60 & 3.6 & $<6$ & 13 & 0.125 & 0.116 & 35.0 \\
\hline OI02 & 10 & 0.2 & 7 & $<10$ & 0.65 & 1.0 & 0.3 & 1 & 9 & $<0.1$ & 0.610 & 4.40 & 5.7 & $<6$ & 11 & 0.183 & 0.174 & 32.0 \\
\hline OIO4 & 8 & 0.2 & 6 & $<10$ & 0.48 & 0.7 & 0.2 & $<1$ & 12 & $<0.1$ & 0.910 & 3.40 & 3.9 & $<6$ & 18 & 0.127 & 0.131 & 9.5 \\
\hline OI 21 & 19 & $<0.1$ & 4 & $<10$ & 0.38 & 0.4 & $<0.2$ & 1 & 7 & $<0.1$ & 0.180 & 2.20 & 3.1 & $<6$ & 11 & 0.053 & 0.084 & 11.0 \\
\hline MI 18 & 5 & 0.1 & 6 & $<10$ & 0.29 & 0.8 & $<0.2$ & 2 & 11 & $<0.1$ & 0.041 & 2.90 & 2.3 & $<6$ & 26 & 0.129 & 0.133 & 28.0 \\
\hline
\end{tabular}


TABLE 5. - Dissolved chemical constituent

\begin{tabular}{|c|c|c|c|c|c|c|c|c|c|c|c|c|c|c|c|c|c|c|}
\hline $\begin{array}{l}\text { Lat1- } \\
\text { tude }\end{array}$ & $\begin{array}{l}\text { Long 1- } \\
\text { tude }\end{array}$ & $\begin{array}{l}\text { Labora- } \\
\text { tory } \\
\text { lden- } \\
\text { tifi- } \\
\text { cation } \\
\text { number }\end{array}$ & $\begin{array}{l}\text { Split } \\
\text { sample } \\
\text { iden } \\
\text { tifi- } \\
\text { cation } \\
\text { number }\end{array}$ & $\begin{array}{c}\text { Sample } \\
\text { type }\end{array}$ & $\begin{array}{c}\text { As } \\
(\mu \mathrm{g} / \mathrm{L})\end{array}$ & $\begin{array}{c}\mathrm{Ba} \\
(\mu \mathrm{g} / \mathrm{L})\end{array}$ & $\underset{(\mu \mathrm{g} / \mathrm{L})}{\mathrm{Be}}$ & $\begin{array}{l}\text { Total } \\
\text { inarganic } \\
\text { carbon } \\
(\mathrm{mg} / \mathrm{L})\end{array}$ & $\underset{(\mathrm{mg} / \mathrm{L})}{\mathrm{Ca}}$ & $\begin{array}{c}C d \\
(\mu \mathrm{g} / L)\end{array}$ & $\begin{array}{c}\mathrm{Cl} \\
(\mathrm{mg} / \mathrm{L})\end{array}$ & $\begin{array}{c}\text { Co } \\
(\mu g / L)\end{array}$ & $\begin{array}{c}\mathrm{Cu} \\
(\mu \mathrm{g} / \mathrm{L})\end{array}$ & $\underset{(\mathrm{mg} / \mathrm{L})}{\mathrm{F}}$ & $\begin{array}{c}\mathrm{Fe} \\
(\mathrm{ug} / \mathrm{L})\end{array}$ & $\begin{array}{c}\mathrm{pH} \\
(\mu \mathrm{g} / \mathrm{L})\end{array}$ & $\begin{array}{c}\mathrm{Hg} \\
(\mu \mathrm{g} / \mathrm{L})\end{array}$ & $\begin{array}{c}\mathrm{K} \\
(\mathrm{mg} / \mathrm{L}) \\
\end{array}$ \\
\hline 435243 & 842818 & MI 36 & MI 18 & 2 & 1.0 & 4 & $<0.5$ & 0.4 & 1.20 & 1 & 0.36 & $<3$ & $<10$ & 0.06 & 30 & 4.4 & $<0.1$ & 0.3 \\
\hline 444230 & 843026 & MI08 & & P & $<0.1$ & $<2$ & $<0.5$ & 0.4 & 0.70 & $<1$ & 0.27 & $<3$ & $<10$ & 0.06 & 24 & 4.2 & $<0.1$ & $<0.1$ \\
\hline 444230 & 843026 & MLO9 & & $\mathrm{R}$ & $\leqslant 0.1$ & $<2$ & $<0.5$ & 0.4 & 0.15 & $<1$ & 0.08 & $<3$ & $<10$ & 0.04 & 9 & 5.1 & $<0.1$ & $<0.1$ \\
\hline 444230 & 843026 & MI $10 \mathrm{~A}$ & & A & $<0.1$ & $<2$ & $<0.5$ & 0.4 & 0.18 & $<1$ & 0.15 & $<3$ & $<10$ & 0.03 & 20 & 4.9 & $<0.1$ & 0.1 \\
\hline 444230 & 843026 & ML $10 B$ & & B & $<0.1$ & $<2$ & $<0.5$ & 0.4 & 0.57 & $<1$ & 0.27 & $<3$ & $<10$ & 0.07 & 54 & 4.2 & $<0.1$ & 0.1 \\
\hline 444230 & 843026 & MIIOC & & $\mathrm{c}$ & $<0.1$ & 3 & $<0.5$ & 0.4 & 0.54 & $<1$ & 0.52 & $<3$ & $<10$ & 0.09 & 43 & 3.8 & $<0.1$ & 0.1 \\
\hline 444230 & 843026 & MI $10 D$ & & D & $<0.1$ & $<2$ & $<0.5$ & 0.4 & 0.32 & $<1$ & 0.81 & $<3$ & $<10$ & 0.06 & 21 & 3.8 & $<0.1$ & $<0.1$ \\
\hline 444230 & 843026 & MI 32 & MI09 & z & $<0.1$ & $<2$ & $<0.5$ & 0.4 & 0.14 & $<1$ & 0.19 & $<3$ & $<10$ & 0.09 & 4 & 5.1 & $<0.1$ & $<0.1$ \\
\hline 452226 & 843054 & MI 15 & & p & $<0.1$ & 3 & $<0.5$ & 0.4 & 0.80 & 16 & 0.32 & $<3$ & 10 & 0.05 & 19 & 4.4 & $<0.1$ & $<0.1$ \\
\hline 423432 & 843523 & MIOI & & P & $<0.1$ & 5 & $<0.5$ & 0.4 & 0.39 & $<1$ & 0.61 & $<3$ & $<10$ & 0.12 & 22 & 4.5 & $<0.1$ & $<0.1$ \\
\hline 423432 & 843523 & MI02 & & $\mathrm{R}$ & $<0.1$ & 3 & $<0.5$ & 0.4 & 0.51 & $<1$ & 0.42 & 3 & 10 & 0.07 & 65 & 4.6 & $<0.1$ & 0.1 \\
\hline 423432 & 843523 & MI03A & & A & $<0.1$ & $<2$ & $<0.5$ & 0.4 & 0.42 & $<1$ & 0.32 & $<3$ & $<10$ & 0.07 & 40 & 4.3 & $<0.1$ & $<0.1$ \\
\hline 423432 & 843523 & MI03B & & B & $<0.1$ & $<2$ & $<0.5$ & 0.4 & 0.50 & $<1$ & 0.38 & $<3$ & $<10$ & 0.06 & 35 & 4.0 & $<0.1$ & 0.1 \\
\hline 423432 & 843523 & MI03C & & $\mathrm{C}$ & $<0.1$ & 4 & $<0.5$ & 0.4 & 0.85 & $<1$ & 0.76 & $<3$ & $<10$ & 0.07 & 55 & 4.3 & $<0.1$ & 0.1 \\
\hline 423432 & 843523 & MI03D & & D & $<0.1$ & 2 & $<0.5$ & 0.4 & 0.43 & $<1$ & 0.29 & $<3$ & $<10$ & 0.07 & 27 & 3.2 & $<0.1$ & 0.1 \\
\hline 461222 & 843548 & MI 28 & & P & 1.0 & $<2$ & $<0.5$ & 0.4 & 0.42 & 3 & 0.24 & $<3$ & $<10$ & 0.05 & 21 & 4.2 & $<0.1$ & $<0.1$ \\
\hline 461222 & 843548 & MI 33 & MI 28 & z & 1.0 & $<2$ & $<0.5$ & 0.4 & 0.51 & 2 & 0.32 & $<3$ & $<10$ & 0.05 & 19 & 4.1 & $<0.1$ & 0.1 \\
\hline 415148 & 843622 & MIO4 & & P & $<0.1$ & $<2$ & $<0.5$ & 0.4 & 0.47 & $<1$ & 0.77 & $<3$ & $<10$ & 0.11 & 35 & 4.3 & $<0.1$ & $<0.1$ \\
\hline 403408 & 850054 & IN06 & & p & 1.0 & 4 & $<0.5$ & 0.4 & 1.50 & 17 & 0.34 & $<3$ & 10 & 0.08 & 81 & 4.6 & $<0.1$ & 0.1 \\
\hline 394331 & 851155 & IN09 & & $\mathrm{P}$ & 1.0 & 3 & $<0.5$ & 0.6 & 0.86 & 3 & 0.23 & $<3$ & 10 & 0.06 & 44 & 4.4 & $<0.1$ & 0.1 \\
\hline 390701 & 851322 & IN12 & & p & 1.0 & 2 & $<0.5$ & 0.4 & 1.10 & 130 & 0.52 & $<3$ & 60 & 0.11 & 34 & 4.2 & $<0.1$ & 0.1 \\
\hline 411958 & 852235 & INO3 & & $\mathrm{P}$ & $<0.1$ & $<2$ & $<0.5$ & 0.6 & 0.70 & 8 & 0.17 & $<3$ & $<10$ & 0.06 & 24 & 4.4 & $<0.1$ & $<0.1$ \\
\hline 411958 & 852235 & IN1 $5 \mathrm{~A}$ & & A & $<0.1$ & 3 & $<0.5$ & 0.6 & 0.72 & 1 & 0.75 & $<3$ & 10 & 0.05 & 21 & 4.4 & $<0.1$ & 0.1 \\
\hline 411958 & 852235 & IN15B & & B & 1.0 & 4 & $<0.5$ & 0.3 & 3.10 & 13 & 0.47 & $<3$ & 10 & 0.04 & 31 & 6.4 & $<0.1$ & 0.1 \\
\hline 411958 & 852235 & IN15C & & C & 1.0 & 3 & $<0.5$ & 0.8 & 2.70 & 24 & 0.38 & $<3$ & 20 & 0.07 & 15 & 4.4 & $<0.1$ & 0.1 \\
\hline 411958 & 852235 & IN15D & & D & 1.0 & $<2$ & $<0.5$ & 0.6 & 0.79 & 5 & 0.33 & $<3$ & 10 & 0.05 & 29 & 4.4 & $<0.1$ & 0.1 \\
\hline 411958 & 852235 & IN20 & IN15C & $\mathrm{z}$ & $<0.1$ & 3 & $<0.5$ & 0.6 & 2.50 & 20 & 0.42 & $<3$ & 20 & 0.06 & 14 & 6.3 & $<0.1$ & 0.1 \\
\hline 443818 & 853110 & MI 14 & & $\mathbf{P}$ & $<0.1$ & $<2$ & $<0.5$ & 0.4 & 0.53 & $<1$ & 0.30 & $<3$ & $<10$ & 0.05 & 19 & 4.2 & $<0.1$ & $<0.1$ \\
\hline 462459 & 853429 & MI 30 & & $\mathrm{p}$ & $<0.1$ & 2 & $<0.5$ & 0.2 & 0.17 & $<1$ & 0.16 & $<3$ & $<10$ & 0.04 & 6 & 4.9 & $<0.1$ & $<0.1$ \\
\hline 462459 & 853429 & MI 31 & & s & $<0.1$ & $<2$ & $<0.5$ & 0.4 & 0.09 & 8 & 0.26 & $<3$ & $<10$ & 0.06 & 7 & 4.7 & $<0.1$ & $<0.1$ \\
\hline 462459 & 853429 & MI 35 & MI 31 & $z$ & $<0.1$ & $<2$ & $<0.5$ & 0.4 & 0.17 & $<1$ & 0.19 & $<3$ & $<10$ & 0.03 & 6 & 4.8 & $<0.1$ & $<0.1$ \\
\hline 432610 & 854000 & MI 12 & & P & $<0.1$ & 3 & $<0.5$ & 0.4 & 0.84 & 14 & 0.40 & $<3$ & 10 & 0.08 & 43 & 4.3 & $<0.1$ & 0.1 \\
\hline 422121 & 854916 & MIO6 & & $\mathrm{P}$ & 1.0 & 3 & $<0.5$ & 0.4 & 0.60 & $<1$ & 1.90 & $<3$ & $<10$ & 0.30 & 48 & 4.4 & $<0.1$ & 0.2 \\
\hline 422121 & 854916 & MI 34 & MI06 & Z & $<0.1$ & $<2$ & $<0.5$ & 0.4 & 0.55 & 4 & 0.45 & $<3$ & $<10$ & 0.03 & 38 & 4.4 & $<0.1$ & 0.1 \\
\hline 435640 & 855103 & MI 13 & & P & $<0.1$ & 3 & $<0.5$ & 0.4 & 0.91 & 11 & 1.30 & $<3$ & $<10$ & 0.11 & 26 & 4.6 & $<0.1$ & 0.1 \\
\hline 435640 & 855103 & MI 37 & MI 13 & $i$ & $<0.1$ & 3 & $<0.5$ & 0.4 & 0.83 & 1 & 1.00 & $<3$ & $<10$ & 0.03 & 23 & 4.6 & $<0.1$ & $<0.1$ \\
\hline 411233 & 855616 & INO2 & & P & 1.0 & 3 & $<0.5$ & 0.4 & 1.20 & 17 & 0.37 & $<3$ & 10 & 0.06 & 25 & 4.6 & $<0.1$ & 0.1 \\
\hline 382805 & 860334 & IN14 & & p & $<0.1$ & 5 & $<0.5$ & 0.4 & 1.10 & 3 & 0.28 & $<3$ & 10 & 0.05 & 51 & 4.3 & $<0.1$ & 0.1 \\
\hline 382805 & 860334 & IN19 & IN14 & z & 1.0 & 4 & $<0.5$ & 0.4 & 0.83 & $<1$ & 0.35 & $<3$ & $<10$ & 0.06 & 30 & 4.3 & $<0.1$ & 0.1 \\
\hline 390744 & 860641 & IN1 1 & & P & $<0.1$ & 3 & $<0.5$ & 3.5 & 1.50 & $<1$ & 0.55 & $<3$ & $<10$ & 0.06 & 14 & 7.0 & $<0.1$ & 1.5 \\
\hline 390744 & 860641 & IN18 & IN1 1 & z & 1.0 & 3 & $<0.5$ & 2.9 & 1.40 & 2 & 0.54 & $<3$ & 10 & 0.06 & 20 & 7.1 & $<0.1$ & 1.3 \\
\hline 400126 & 861855 & INO8 & & $\mathrm{P}$ & 1.0 & 5 & $<0.5$ & 0.4 & 1.70 & 3 & 0.31 & $<3$ & $<10$ & 0.07 & 43 & 4.8 & $<0.1$ & $<0.1$ \\
\hline 400126 & 861855 & IN16A & & A & $<0.1$ & $<2$ & $<0.5$ & 0.8 & 0.30 & 35 & 0.35 & $<3$ & 30 & 0.05 & 22 & 5.1 & $<0.1$ & 0.1 \\
\hline 400126 & 861855 & IN16B & & B & $<0.1$ & $<2$ & $<0.5$ & 0.1 & 0.54 & $<1$ & 0.25 & $<3$ & $<10$ & 0.03 & 29 & 5.1 & 0.1 & $<0.1$ \\
\hline 400126 & 861855 & IN16C & & $\mathrm{c}$ & 1.0 & 4 & $<0.5$ & 0.1 & 1.30 & $<1$ & 0.71 & $<3$ & $<10$ & 0.09 & 25 & 5.1 & $<0.1$ & $<0.1$ \\
\hline 400126 & 861855 & IN16D & & D & 1.0 & 4 & $<0.5$ & 0.2 & 1.00 & $<1$ & 0.22 & $<3$ & $<10$ & 0.08 & 31 & 5.1 & $<0.1$ & $<0.1$ \\
\hline 400126 & 861855 & IN21 & IN16B & Z & $<0.1$ & $<2$ & $<0.5$ & 0.4 & 0.65 & $<1$ & 0.67 & $<3$ & $<10$ & 0.11 & 26 & 4.4 & $<0.1$ & $<0.1$ \\
\hline 403707 & 861914 & INOS & & $\mathrm{P}$ & $<0.1$ & 4 & $<0.5$ & 0.4 & 1.10 & 6 & 0.25 & $<3$ & $<10$ & 0.06 & 53 & 4.6 & $<0.1$ & $<0.1$ \\
\hline 420159 & 862009 & MI05 & & p & $<0.1$ & 6 & $<0.5$ & 0.6 & 0.66 & $<1$ & 0.78 & $<3$ & $<10$ & 0.08 & 82 & 4.4 & $<0.1$ & 0.1 \\
\hline 461026 & 862518 & MI 29 & & $\mathrm{p}$ & $<0.1$ & $<2$ & $<0.5$ & 0.4 & 0.12 & $<1$ & 0.17 & $<3$ & $<10$ & 0.02 & 4 & 4.9 & $<0.1$ & $<0.1$ \\
\hline
\end{tabular}




\begin{tabular}{|c|c|c|c|c|c|c|c|c|c|c|c|c|c|c|c|c|c|c|}
\hline $\begin{array}{l}\text { Labora- } \\
\text { tory } \\
\text { lden- } \\
\text { tifi- } \\
\text { cation } \\
\text { number }\end{array}$ & 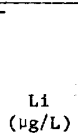 & $\underset{(\mathrm{mg} / \mathrm{L})}{\mathrm{Mg}}$ & $\begin{array}{c}\mathrm{Mn} \\
(\mu \mathrm{g} / \mathrm{L})\end{array}$ & $\begin{array}{c}\text { Mo } \\
(\mu \mathrm{g} / \mathrm{L})\end{array}$ & $\begin{array}{l}\mathrm{NH}_{4}-\mathrm{N} \\
(\mathrm{mg} / \mathrm{L})\end{array}$ & $\begin{array}{r}\mathrm{NO}_{3}-\mathrm{N} \\
(\mathrm{mg} / \mathrm{L})\end{array}$ & $\begin{array}{c}\mathrm{Na} \\
(\mathrm{mg} / \mathrm{L})\end{array}$ & $\begin{array}{c}N i \\
(\mu \mathrm{g} / \mathrm{L})\end{array}$ & $\begin{array}{c}P b \\
(\mu g / L)\end{array}$ & $\begin{array}{c}\mathrm{Se} \\
(\mu \mathrm{g} / \mathrm{L})\end{array}$ & $\begin{array}{c}S i \\
(\mu g / L)\end{array}$ & $\begin{array}{c}\mathrm{SO}_{4} \\
(\mathrm{~m} / \mathrm{L})\end{array}$ & $\begin{array}{c}\mathrm{Sr} \\
(\mu \mathrm{g} / \mathrm{L})\end{array}$ & $\begin{array}{c}\mathrm{V} \\
(\mu \mathrm{g} / \mathrm{L})\end{array}$ & $\begin{array}{c}\mathrm{Zn} \\
(\mu \mathrm{g} / \mathrm{L})\end{array}$ & $\begin{array}{c}\text { Cations } \\
\text { sun } \\
\text { (meq/L) }\end{array}$ & $\begin{array}{c}\text { Antons } \\
\text { sun } \\
\text { (meq/L) }\end{array}$ & $\begin{array}{l}\text { Spectf tc } \\
\text { conductance } \\
(\mu \mathrm{mho} / \mathrm{cm} \\
\left(225^{\circ} \mathrm{C}\right)\end{array}$ \\
\hline MI 36 & 23 & $<0.1$ & 5 & $<10$ & 0.30 & 0.8 & $<0.2$ & $<1$ & 8 & $<0.1$ & 0.082 & 2.90 & 3.9 & $<6$ & 21 & 0.121 & 0.128 & 26.0 \\
\hline MI08 & $<4$ & $<0.1$ & 5 & $<10$ & 0.25 & 0.7 & $<0.2$ & 1 & 8 & $<0.1$ & 0.330 & 2.50 & 3.7 & $<6$ & 9 & 0.116 & 0.110 & 26.0 \\
\hline MLO9 & 4 & $<0.1$ & 1 & $<10$ & $<0.01$ & 0.1 & $<0.2$ & 2 & 1 & $<0.1$ & 0.320 & 0.42 & 2.6 & $<6$ & 4 & 0.015 & 0.018 & 4.5 \\
\hline MIIOA & $<4$ & $<0.1$ & 2 & $<10$ & $<0.01$ & $<0.1$ & $<0.2$ & 2 & 2 & $<0.1$ & 0.400 & 0.36 & 2.5 & $<6$ & $<3$ & 0.022 & 0.012 & 3.0 \\
\hline MI $1 O B$ & $<4$ & 0.1 & 5 & $<10$ & 0.14 & 0.7 & $<0.2$ & 2 & 17 & $<0.1$ & 0.280 & 2.20 & 4.2 & $<6$ & 23 & 0.110 & 0.103 & 16.0 \\
\hline MI 1OC & $<4$ & 0.1 & 6 & $<10$ & $<0.01$ & $<0.1$ & 0.2 & 1 & 18 & $<0.1$ & 0.270 & 3.10 & 3.9 & $<6$ & 23 & 0.202 & 0.079 & 36.0 \\
\hline MI 10D & 4 & $<0.1$ & 3 & $<10$ & 0.29 & 0.7 & $<0.2$ & 1 & 7 & $<0.1$ & 0.210 & 3.00 & 2.6 & $<6$ & 16 & 0.195 & 0.135 & 16.0 \\
\hline MI 32 & 24 & $<0.1$ & 1 & $<10$ & 0.07 & 0.1 & $<0.2$ & $<1$ & 2 & $<0.1$ & 0.036 & 0.41 & 1.4 & $<6$ & 3 & 0.020 & 0.021 & 1.8 \\
\hline MI 15 & $<4$ & $<0.1$ & 3 & $<10$ & 0.28 & 0.8 & 0.2 & $<1$ & 9 & $<0.1$ & 0.023 & 2.40 & 1.3 & $<6$ & 80 & 0.108 & 0.116 & 21.0 \\
\hline MI01 & $<4$ & $<0.1$ & 4 & $<10$ & 0.26 & 0.4 & $<0.2$ & 2 & 8 & $<0.1$ & 0.030 & 2.30 & 1.9 & $<6$ & $<3$ & 0.070 & 0.094 & 13.0 \\
\hline MIO2 & $<4$ & 0.1 & 6 & $<10$ & 0.37 & 0.5 & $<0.2$ & 2 & 9 & $<0.1$ & 0.510 & 2.40 & 4.7 & $<6$ & 9 & 0.085 & 0.097 & 16.0 \\
\hline MI03A & $<4$ & 0.1 & 4 & $<10$ & 0.43 & 0.6 & $<0.2$ & 1 & 12 & $<0.1$ & 0.037 & 2.90 & 2.5 & $<6$ & 9 & 0.110 & 0.112 & 21.0 \\
\hline MIO3B & $<4$ & 0.1 & 5 & $<10$ & 0.18 & 0.6 & $<0.2$ & 1 & 9 & $<0.1$ & 0.220 & 1.90 & 3.3 & $<6$ & 13 & 0.146 & 0.093 & 15.0 \\
\hline MIO3C & 4 & 0.1 & 9 & $<10$ & 0.63 & 0.9 & 0.5 & 1 & 15 & $<0.1$ & 0.380 & 3.10 & 4.9 & $<6$ & 40 & 0.168 & 0.150 & 21.0 \\
\hline MI03D & 4 & 0.1 & 6 & $<10$ & 0.45 & 0.7 & $<0.2$ & 1 & 7 & $<0.1$ & 0.220 & 3.00 & 3.1 & $<6$ & 10 & 0.693 & 0.120 & 21.0 \\
\hline MI28 & 20 & 0.1 & 5 & $<10$ & 0.46 & 0.9 & $<0.2$ & 2 & 13 & $<0.1$ & 0.011 & 2.80 & 1.8 & $<6$ & 12 & 0.125 & 0.129 & 38.0 \\
\hline MI33 & 26 & $<0.1$ & 4 & $<10$ & 0.45 & 0.9 & $<0.2$ & $<1$ & 12 & $<0.1$ & $<0.009$ & 2.80 & 1.9 & $<6$ & 11 & 0.137 & 0.131 & 35.0 \\
\hline MIO4 & $<4$ & $<0.1$ & 6 & $<10$ & 0.41 & 0.7 & $<0.2$ & 4 & 11 & $<0.1$ & 0.190 & 3.20 & 2.9 & $<6$ & 10 & 0.103 & 0.138 & 26.0 \\
\hline IN06 & 5 & 0.3 & 12 & $<10$ & 0.69 & 1.0 & 0.3 & 2 & 13 & $<0.1$ & 0.360 & 5.40 & 5.6 & $<6$ & 55 & 0.187 & 0.193 & 29.0 \\
\hline [NO9 & 6 & 0.1 & 9 & $<10$ & 0.69 & 0.8 & 0.2 & 2 & 4 & $<0.1$ & 0.510 & 4.40 & 6.2 & $<6$ & 11 & 0.149 & 0.155 & 27.0 \\
\hline IN12 & 6 & 0.1 & 18 & $<10$ & 0.34 & 0.8 & $<0.2$ & 1 & 10 & $<0.1$ & 0.100 & 3.90 & 3.6 & $<6$ & 115 & 0.151 & 0.153 & 29.0 \\
\hline LNO3 & 5 & $<0.1$ & 6 & $<10$ & 0.44 & 0.6 & $<0.2$ & 7 & 5 & $<0.1$ & 0.033 & 3.00 & 1.6 & $<6$ & 33 & 0.106 & 0.110 & 21.0 \\
\hline LN15A & 7 & 0.1 & 5 & $<10$ & 1.10 & 0.8 & 0.2 & 2 & 10 & $<0.1$ & 0.180 & 4.40 & 3.5 & $<6$ & 16 & 0.171 & 0.170 & 26.0 \\
\hline LN15B & 6 & 0.6 & 20 & $<10$ & 1.30 & 1.6 & 0.5 & 3 & 5 & $<0.1$ & 0.300 & 3.30 & 5.8 & $<6$ & 62 & 0.319 & 0.196 & 38.0 \\
\hline IN15C & 7 & 0.4 & 17 & $<10$ & 0.98 & 1.0 & 0.3 & 2 & 4 & $<0.1$ & 0.370 & 5.90 & 6.2 & $<6$ & 59 & 0.291 & 0.205 & 30.0 \\
\hline IN15D & 5 & 0.1 & 7 & $<10$ & 0.81 & 0.6 & 0.3 & $<1$ & 8 & $<0.1$ & 0.360 & 3.80 & 4.3 & $<6$ & 42 & 0.158 & 0.131 & 18.0 \\
\hline IN20 & 5 & 0.4 & 19 & $<10$ & 0.68 & 1.0 & 0.2 & 3 & 1 & $<0.1$ & 0.650 & 7.10 & 7.9 & $<6$ & 67 & 0.215 & 0.231 & 32.0 \\
\hline MI 14 & 5 & $<0.1$ & 3 & $<10$ & 0.27 & 0.7 & $<0.2$ & $<1$ & 7 & $<0.1$ & $<0.009$ & 2.30 & 1.0 & $<6$ & 13 & 0.109 & 0.106 & 29.0 \\
\hline MI 30 & 20 & $<0.1$ & 1 & $<10$ & 0.08 & 0.1 & $<0.2$ & $<1$ & 3 & $<0.1$ & $<0.009$ & 0.65 & 1.4 & $<6$ & 3 & 0.027 & 0.025 & 3.8 \\
\hline MI31 & 24 & $<0.1$ & $<1$ & $<10$ & 0.08 & 0.2 & $<0.2$ & $<1$ & 2 & $<0.1$ & 0.086 & 0.69 & 1.4 & $<6$ & 8 & 0.030 & 0.036 & 5.3 \\
\hline MI 35 & 24 & $<0.1$ & 1 & $<10$ & 0.08 & 0.2 & $<0.2$ & $<1$ & 2 & $<0.1$ & 0.034 & 0.63 & 1.6 & $<6$ & $<3$ & 0.030 & 0.033 & 5.7 \\
\hline MI 12 & $<4$ & $<0.1$ & 7 & $<10$ & 0.43 & 0.9 & $<0.2$ & 1 & 15 & $<0.1$ & 0.029 & 3.60 & 2.0 & $<6$ & 257 & 0.123 & 0.150 & 38.0 \\
\hline MI06 & $<4$ & 0.1 & 9 & $<10$ & 0.68 & 0.7 & 0.2 & 1 & 11 & $<0.1$ & 0.430 & 3.90 & 5.3 & $<6$ & 16 & 0.135 & 0.185 & 19.0 \\
\hline MI34 & 21 & 0.1 & 7 & $<10$ & 0.68 & 0.7 & 0.2 & $<1$ & 9 & $<0.1$ & 0.072 & 3.00 & 2.5 & $<6$ & 18 & 0.133 & 0.125 & 27.0 \\
\hline MI 13 & 5 & 0.2 & 28 & $<10$ & 0.28 & 0.8 & 0.7 & l & 9 & $<0.1$ & 0.025 & 2.50 & 1.9 & $<6$ & 17 & 0.137 & 0.146 & 31.0 \\
\hline MI37 & 26 & $<0.1$ & 22 & $<10$ & 0.28 & 0.8 & 0.6 & $<1$ & 8 & $<0.1$ & 0.090 & 2.40 & 3.7 & $<6$ & 11 & 0.113 & 0.135 & 22.0 \\
\hline INO2 & 6 & $<0.1$ & 28 & $<10$ & 0.11 & 0.4 & 0.2 & 6 & 9 & $<0.1$ & 0.039 & 4.80 & 2.3 & $<6$ & 67 & 0.102 & 0.139 & 27.0 \\
\hline IN14 & 4 & $<0.1$ & 44 & $<10$ & 0.51 & 0.7 & 0.2 & 1 & 6 & $<0.1$ & 0.150 & 4.80 & 4.2 & $<6$ & 18 & 0.150 & 0.158 & 27.0 \\
\hline IN19 & 8 & $<0.1$ & 32 & $<10$ & 0.50 & 0.7 & 0.2 & 1 & 4 & $<0.1$ & 0.540 & 5.60 & 6.3 & $<6$ & 13 & 0.136 & 0.176 & 28.0 \\
\hline IN11 & 6 & 0.1 & 12 & $<10$ & 1.90 & 0.6 & 0.2 & 1 & 5 & $<0.1$ & 0.180 & 5.00 & 6.4 & $<6$ & 13 & 0.228 & 0.162 & 51.0 \\
\hline IN18 & 6 & 0.2 & 11 & $<10$ & 2.80 & 0.6 & 0.2 & $<1$ & 3 & $<0.1$ & 0.350 & 6.00 & 7.6 & $<6$ & 13 & 0.295 & 0.183 & 48.0 \\
\hline I N08 & 6 & 0.3 & 13 & $<10$ & 0.65 & 0.9 & 0.3 & 1 & 8 & $<0.1$ & 0.510 & 4.90 & 6.3 & $<6$ & 29 & 0.185 & 0.175 & 34.0 \\
\hline INl $6 \mathrm{~A}$ & 6 & 0.1 & 2 & $<10$ & 0.58 & 0.4 & 0.2 & 1 & 8 & $<0.1$ & 0.230 & 2.50 & 2.3 & $<6$ & 38 & 0.081 & 0.090 & 23.0 \\
\hline IN16B & 6 & 0.1 & 3 & $<10$ & 0.52 & 0.6 & $<0.2$ & 1 & 11 & $<0.1$ & 0.460 & 2.30 & 3.4 & $<6$ & 24 & 0.080 & 0.098 & 13.0 \\
\hline IN16C & 6 & 0.2 & 9 & $<10$ & 1.20 & 1.1 & 0.2 & 1 & 3 & $<0.1$ & 0.590 & 6.10 & 4.9 & $<6$ & 76 & 0.184 & 0.225 & 28.0 \\
\hline IN16D & 6 & 0.1 & 8 & $<10$ & 0.99 & 0.7 & $<0.2$ & 3 & 5 & $<0.1$ & 0.280 & 4.50 & 3.3 & $<6$ & 14 & 0.137 & 0.150 & 23.0 \\
\hline IN21 & 8 & $<0.1$ & 2 & $<10$ & 0.28 & 0.6 & $<0.2$ & 6 & 12 & $<0.1$ & 0.200 & 2.60 & 2.7 & $<6$ & 23 & 0.092 & 0.116 & $\therefore \quad 21.0$ \\
\hline IN05 & 7 & 0.1 & 10 & $<10$ & 0.76 & 0.7 & 0.2 & 3 & 9 & $<0.1$ & 0.580 & 4.50 & 7.1 & $<6$ & 26 & 0.151 & 0.151 & 25.0 \\
\hline MI05 & $<4$ & 0.1 & 12 & $<10$ & 0.40 & 0.7 & 0.2 & 2 & 11 & $<0.1$ & 0.400 & 3.20 & 4.3 & $<6$ & 14 & 0.118 & 0.138 & 22.0 \\
\hline MI 29 & 20 & $<0.1$ & $<1$ & $<10$ & 0.10 & 0.2 & $<0.2$ & $<1$ & $<1$ & $<0.1$ & 0.340 & 0.45 & 3.2 & $<6$ & $<3$ & 0.026 & 0.028 & 4.1 \\
\hline
\end{tabular}




\begin{tabular}{|c|c|c|c|c|c|c|c|c|c|c|c|c|c|c|c|c|c|c|}
\hline $\begin{array}{l}\text { Lat1- } \\
\text { tude }\end{array}$ & $\begin{array}{l}\text { Long i- } \\
\text { tude }\end{array}$ & $\begin{array}{l}\text { Labora- } \\
\text { tory } \\
\text { iden- } \\
\text { tif1- } \\
\text { cation } \\
\text { number }\end{array}$ & $\begin{array}{l}\text { Split } \\
\text { sample } \\
\text { Iden } \\
\text { tif } 1- \\
\text { cation } \\
\text { number }\end{array}$ & $\begin{array}{c}\text { Sample } \\
\text { type }\end{array}$ & $\begin{array}{c}\text { As } \\
(\mu \mathrm{g} / \mathrm{L})\end{array}$ & $\begin{array}{c}\text { Ba } \\
(\mu g / L)\end{array}$ & $\begin{array}{c}\mathrm{Be} \\
(\mu \mathrm{g} / \mathrm{L})\end{array}$ & $\begin{array}{l}\text { Total } \\
\text { Inorganic } \\
\text { carbon } \\
(\mathrm{mg} / \mathrm{L})\end{array}$ & $\begin{array}{c}\mathrm{Ca} \\
(\mathrm{mg} / \mathrm{L})\end{array}$ & $\begin{array}{c}\mathrm{Cd} \\
(\mu \mathrm{g} / \mathrm{L})\end{array}$ & $\begin{array}{c}\mathrm{Cl} \\
(\mathrm{mg} / \mathrm{L})\end{array}$ & $\begin{array}{c}\text { Co } \\
(\mu g / L)\end{array}$ & $\begin{array}{c}\mathrm{Cu} \\
(\mu \mathrm{g} / \mathrm{L})\end{array}$ & $\underset{(\mathrm{mg} / \mathrm{L})}{\mathbf{F}}$ & $\begin{array}{c}\mathrm{Fe} \\
(\mu \mathrm{g} / \mathrm{L})\end{array}$ & $\begin{array}{c}\mathrm{pH} \\
(\mu \mathrm{g} / \mathrm{L})\end{array}$ & $\begin{array}{c}\mathrm{Hg} \\
(\mu \mathrm{g} / \mathrm{L})\end{array}$ & $\underset{(\mathrm{mg} / \mathrm{L})}{\mathrm{K}}$ \\
\hline 411947 & 864703 & INOI & & $\mathrm{P}$ & $<0.1$ & 5 & $<0.5$ & 0.4 & 0.75 & 21 & 0.22 & $<3$ & $<10$ & 0.13 & 49 & 4.6 & 0.1 & $<0.1$ \\
\hline 404859 & 865014 & INO4 & & $P$ & 1.0 & 6 & $<0.5$ & 0.4 & 1.40 & 13 & 0.30 & $<3$ & 10 & 0.06 & 73 & 4.4 & $<0.1$ & 0.1 \\
\hline 404859 & 865014 & IN17 & IN04 & 2 & $<0.1$ & 5 & $<0.5$ & 0.4 & 1.30 & 14 & 0.68 & $<3$ & 10 & 0.31 & 73 & 4.4 & $<0.1$ & 0.1 \\
\hline 390929 & 870213 & LN10 & & $\mathrm{P}$ & $<0.1$ & 2 & $<0.5$ & 0.8 & 0.85 & 14 & 0.21 & $<3$ & $<10$ & 0.09 & 14 & 4.4 & $<0.1$ & $<0.1$ \\
\hline 382221 & 870324 & IN13 & & $\mathbf{P}$ & 1.0 & 3 & $<0.5$ & 0.4 & 2.20 & 1 & 0.26 & $<3$ & 10 & 0.09 & 37 & 4.8 & 0.1 & 0.1 \\
\hline 395610 & 870605 & IN07 & & $\mathbf{P}$ & 1.0 & 3 & $<0.5$ & 0.8 & 1.20 & 92 & 0.27 & $<3$ & 50 & 0.07 & 45 & 4.3 & $<0.1$ & 0.1 \\
\hline 454300 & 871115 & ML 20 & & P & 1.0 & 2 & $<0.5$ & 0.4 & 0.61 & 121 & 1.80 & $<3$ & 100 & 0.11 & 33 & 4.1 & $<0.1$ & 0.1 \\
\hline 454300 & 871115 & MI 21 & & $\mathrm{R}$ & 1.0 & 2 & $<0.5$ & 0.4 & 0.66 & $<1$ & 0.23 & 3 & $<10$ & 0.09 & 32 & 4.1 & $<0.1$ & 0.1 \\
\hline 454300 & 871115 & MI $22 \mathrm{~A}$ & & A & 1.0 & 4 & $<0.5$ & 0.4 & 0.83 & $<1$ & 0.55 & $<3$ & $<10$ & 0.14 & 74 & 4.0 & $<0.1$ & 0.1 \\
\hline 454300 & 871115 & MI 22B & & B & 1.0 & $<2$ & $<0.5$ & 0.4 & 0.28 & $<1$ & 0.17 & $<3$ & $<10$ & 0.04 & 58 & 4.0 & $<0.1$ & 0.1 \\
\hline 454300 & 871115 & MI 22C & & $\mathrm{C}$ & 1.0 & 4 & $<0.5$ & 0.1 & 0.86 & $<1$ & 0.40 & $<3$ & $<10$ & 0.05 & 44 & 4.2 & $<0.1$ & 0.1 \\
\hline 454300 & 871115 & MI22D & & D & $<0.1$ & 3 & 0.6 & 0.4 & 0.49 & $<1$ & 0.36 & $<3$ & $<10$ & 0.07 & 21 & 4.2 & 0.1 & $<0.1$ \\
\hline 441908 & 873449 & WI 28 & & P & 1.0 & $<2$ & $<0.5$ & 0.4 & 0.97 & $<1$ & 0.82 & $<3$ & $<10$ & 0.11 & 31 & 4.8 & $<0.1$ & 0.2 \\
\hline 463323 & 874128 & MI 26 & & p & 1.0 & 2 & $<0.5$ & 0.4 & 0.41 & $<1$ & 0.13 & $<3$ & $<10$ & 0.05 & 31 & 4.2 & $<0.1$ & $<0.1$ \\
\hline 460121 & 875022 & MI 27 & & $\mathrm{P}$ & 1.0 & $<2$ & $<0.5$ & 0.4 & 0.32 & 5 & 0.48 & $<3$ & $<10$ & 0.17 & 21 & 4.2 & $<0.1$ & $<0.1$ \\
\hline 403312 & 875823 & IL10 & & $\mathrm{P}$ & 1.0 & 5 & $<0.5$ & 0.4 & 1.20 & 7 & 0.42 & $<3$ & $<10$ & 0.07 & 36 & 4.5 & $<0.1$ & 0.1 \\
\hline 400002 & 875827 & IL 15 & & P & 1.0 & 7 & $<0.5$ & 0.4 & 1.30 & 4 & 0.53 & $<3$ & $<10$ & 0.08 & 43 & 4.4 & $<0.1$ & $<0.1$ \\
\hline 410833 & 875835 & IL09 & & $\mathrm{P}$ & 1.0 & 5 & $<0.5$ & 0.4 & 1.80 & 9 & 0.57 & $<3$ & $<10$ & 0.09 & 15 & 4.9 & $<0.1$ & 0.1 \\
\hline 384909 & 875931 & IL2O & & p & $<0.1$ & 2 & $<0.5$ & 0.4 & 1.40 & 3 & 0.61 & $<3$ & $<10$ & 0.05 & 13 & 5.8 & $<0.1$ & 0.4 \\
\hline 384909 & 875931 & IL24 & IL20 & Z & $<0.1$ & 6 & $<0.5$ & 0.4 & 1.40 & 6 & 0.32 & $<3$ & $<10$ & 0.08 & 19 & 5.8 & $<0.1$ & 0.3 \\
\hline 392743 & 880145 & IL16 & & $\mathbf{p}$ & 1.0 & 3 & $<0.5$ & 0.4 & 1.50 & 27 & 0.41 & $<3$ & 20 & 0.06 & 41 & 4.4 & 0.1 & $<0.1$ \\
\hline 382015 & 880455 & IL21 & & $P$ & 1.0 & 4 & $<0.5$ & 0.4 & 1.70 & 6 & 0.26 & $<3$ & $<10$ & 0.06 & 28 & 4.8 & $<0.1$ & 0.1 \\
\hline 433434 & 881116 & WI 27 & & P & 1.0 & 2 & $<0.5$ & 0.4 & 1.50 & $<1$ & 0.47 & $<3$ & $<10$ & 0.04 & 22 & 5.4 & $<0.1$ & 0.1 \\
\hline 444949 & 881831 & WI09 & & P & $<0.1$ & $<2$ & $<0.5$ & 0.4 & 0.11 & $<1$ & 0.21 & $<3$ & $<10$ & 0.04 & 5 & 4.9 & 0.1 & $<0.1$ \\
\hline 454530 & 882748 & WI 12 & & $\mathbf{P}$ & 1.0 & $<2$ & $<0.5$ & 0.4 & 0.43 & $<1$ & 0.35 & $<3$ & $<10$ & 0.13 & 37 & 4.3 & 0.1 & 0.1 \\
\hline 463453 & 883412 & MI 25 & & P & 1.0 & $<2$ & 0.6 & 0.4 & 0.21 & $<1$ & 0.07 & $<3$ & $<10$ & 0.05 & 13 & 4.4 & $<0.1$ & 0.1 \\
\hline 471338 & 883744 & MI 24 & & $\mathrm{p}$ & 1.0 & $<2$ & 0.6 & 0.4 & 0.36 & $<1$ & 0.19 & $<3$ & $<10$ & 0.04 & 24 & 4.3 & $<0.1$ & 0.1 \\
\hline 424430 & 883746 & WI 26 & & $\mathbf{P}$ & 1.0 & 3 & $<0.5$ & 0.4 & 1.00 & $<1$ & 1.50 & 4 & $<10$ & 0.35 & 31 & 4.7 & $<0.1$ & 0.1 \\
\hline 382138 & 884854 & IL22 & & $\mathbf{P}$ & 1.0 & 3 & $<0.5$ & 0.4 & 1.40 & 11 & 0.22 & $<3$ & 10 & 0.05 & 29 & 4.5 & $<0.1$ & $<0.1$ \\
\hline 411230 & 885551 & IL08 & & P & 1.0 & 5 & $<0.5$ & 0.4 & 1.60 & 23 & 0.44 & $<3$ & 40 & 0.09 & 13 & 4.8 & $<0.1$ & 0.1 \\
\hline 411230 & 885551 & IL 25 & IL08 & 2 & $<0.1$ & 4 & $<0.5$ & 0.4 & 1.80 & 23 & 0.49 & $<3$ & 10 & 0.11 & 12 & 4.8 & $<0.1$ & 0.1 \\
\hline 403412 & 885628 & IL11 & & $\mathbf{P}$ & $<0.1$ & 7 & $<0.5$ & 0.4 & 1.70 & 6 & 0.49 & $<3$ & $<10$ & 0.07 & 27 & 4.7 & $<0.1$ & 0.1 \\
\hline 403412 & 885628 & IL23 & ILIL & 2 & $<0.1$ & 3 & $<0.5$ & 0.4 & 1.50 & 9 & 0.52 & $<3$ & $<10$ & 0.13 & 22 & 4.7 & $<0.1$ & $<0.1$ \\
\hline 392535 & 885631 & IL 17 & & P & 1.0 & 3 & $<0.5$ & 0.4 & 1.30 & 13 & 0.38 & $<3$ & 10 & 0.06 & 33 & 4.5 & $<0.1$ & $<0.1$ \\
\hline 463339 & 891936 & MI23 & & p & 1.0 & $<2$ & 0.6 & 0.4 & 0.36 & $<1$ & 0.08 & $<3$ & $<10$ & 0.03 & 16 & 4.5 & $<0.1$ & 0.1 \\
\hline 443949 & 892020 & WI08 & & P & $<0.1$ & 3 & $<0.5$ & 0.4 & 0.53 & $<1$ & 0.26 & $<3$ & $<10$ & 0.09 & 24 & 4.4 & 0.1 & $<0.1$ \\
\hline 460307 & 893912 & WI 14 & & P & $<0.1$ & $<2$ & $<0.5$ & 0.4 & 0.10 & $<1$ & 0.14 & $<3$ & $<10$ & 0.10 & 6 & 4.7 & 0.1 & $<0.1$ \\
\hline 460307 & 893912 & WI 15 & & $\mathbf{R}$ & $<0.1$ & $<2$ & $<0.5$ & 0.4 & 0.29 & $<1$ & 0.11 & 3 & $<10$ & 0.09 & 21 & 4.4 & 0.1 & $<0.1$ \\
\hline 460307 & 893912 & WI L6A & & A & $<0.1$ & $<2$ & $<0.5$ & 0.4 & 0.09 & $<1$ & 0.25 & $<3$ & $<10$ & 0.21 & 3 & 3.9 & 0.1 & $<0.1$ \\
\hline 460307 & 893912 & WI 168 & & $B$ & $<0.1$ & 2 & $<0.5$ & 0.4 & 0.57 & $<1$ & 0.30 & $<3$ & $<10$ & 0.33 & 54 & 4.1 & 0.3 & 0.1 \\
\hline 460307 & 893912 & WI L 6C & & C & $<0.1$ & $<2$ & $<0.5$ & 0.4 & 0.34 & $<1$ & 0.36 & $<3$ & $<10$ & 0.22 & 19 & 4.1 & 0.1 & 0.1 \\
\hline 460307 & 893912 & WI 16D & & D & 1.0 & $<2$ & $<0.5$ & 0.4 & 0.27 & $<1$ & 0.22 & $<3$ & $<10$ & 0.13 & 21 & 5.0 & 0.3 & 0.1 \\
\hline 460307 & 893912 & WI 17 & & $\mathrm{~s}$ & $<0.1$ & $<2$ & $<0.5$ & 0.4 & 0.23 & $<1$ & 0.15 & 3 & $<10$ & 0.09 & 15 & 4.6 & $<0.1$ & $<0.1$ \\
\hline 460307 & 893912 & WI 29 & WI 16A & 2 & $<0.1$ & $<2$ & $<0.5$ & 0.4 & 0.18 & $<1$ & 0.27 & $<3$ & $<10$ & 0.06 & 9 & 4.9 & 0.1 & 0.1 \\
\hline 460307 & 893912 & WL 32 & WI 160 & 2 & $<0.1$ & $<2$ & $<0.5$ & 0.4 & 0.36 & $<1$ & 0.28 & $<3$ & $<10$ & 0.11 & 11 & 4.6 & 0.1 & 0.1 \\
\hline 455909 & 894058 & WI 13 & & P & $<0.1$ & $<2$ & $<0.5$ & 0.4 & 0.20 & $<1$ & 0.84 & $<3$ & $<10$ & 0.06 & 10 & 4.9 & 0.1 & 0.1 \\
\hline 432557 & 894358 & WI01 & & P & 1.0 & 3 & $<0.5$ & 0.4 & 1.10 & $<1$ & 0.30 & $<3$ & $<10$ & 0.04 & 17 & 5.4 & $<0.1$ & $<0.1$ \\
\hline 432557 & 894358 & WI02 & & R & 1.0 & 2 & $<0.5$ & 0.4 & 0.93 & $<1$ & 0.22 & $<3$ & $<10$ & 0.08 & 13 & 5.2 & $<0.1$ & $<0.1$ \\
\hline 432557 & 894358 & WI 30 & WI01 & 2 & 1.0 & $<2$ & $<0.5$ & 0.4 & 1.30 & $<1$ & 0.38 & $<3$ & $<10$ & 0.03 & 25 & 5.0 & $<0.1$ & 0.1 \\
\hline 441257 & 894502 & WI07 & & P & $<0.1$ & 5 & $<0.5$ & 0.4 & 0.87 & $<1$ & 0.34 & $<3$ & $<10$ & 0.10 & 44 & 4.4 & 0.1 & 0.1 \\
\hline
\end{tabular}




\begin{tabular}{|c|c|c|c|c|c|c|c|c|c|c|c|c|c|c|c|c|c|c|}
\hline $\begin{array}{l}\text { Labora- } \\
\text { tory } \\
\text { iden- } \\
\text { tifi- } \\
\text { cation } \\
\text { number }\end{array}$ & $\begin{array}{c}\mathrm{Li} \\
(\mu \mathrm{g} / \mathrm{L})\end{array}$ & $\begin{array}{c}\mathrm{Mg} \\
(\mathrm{mg} / \mathrm{L})\end{array}$ & $\begin{array}{c}M n \\
(\mu \mathrm{g} / \mathrm{L})\end{array}$ & $\begin{array}{c}\text { Mo } \\
(\mu \mathrm{g} / \mathrm{L})\end{array}$ & $\begin{array}{l}\mathrm{NH}_{4}-\mathrm{N} \\
(\mathrm{mg} / \mathrm{L})\end{array}$ & $\begin{array}{r}\mathrm{NO}_{3}-\mathrm{N} \\
(\mathrm{mg} / \mathrm{L})\end{array}$ & $\begin{array}{c}\mathrm{Na} \\
(\mathrm{mg} / \mathrm{L})\end{array}$ & $\begin{array}{c}N 1 \\
(\mu \mathrm{g} / \mathrm{L})\end{array}$ & $\begin{array}{c}\mathrm{Pb} \\
(\mu \mathrm{g} / \mathrm{L})\end{array}$ & $\begin{array}{c}\mathrm{Se} \\
(\mu \mathrm{g} / \mathrm{L})\end{array}$ & $\begin{array}{c}S i \\
\left(\mu_{g} / L\right)\end{array}$ & $\begin{array}{c}\mathrm{SO}_{4} \\
(\mathrm{~m} / \mathrm{L})\end{array}$ & $\begin{array}{c}\mathbf{S r} \\
(\mu \mathrm{g} / \mathrm{L})\end{array}$ & $\begin{array}{c}v \\
(\mu g / L)\end{array}$ & $\begin{array}{c}\mathrm{Zn} \\
(\mu \mathrm{g} / \mathrm{L})\end{array}$ & $\begin{array}{c}\text { Cations } \\
\text { suna } \\
\text { (meq/L) }\end{array}$ & $\begin{array}{c}\text { Anions } \\
\text { sum } \\
\text { (meq/L) }\end{array}$ & $\begin{array}{l}\text { Specific } \\
\text { conductance } \\
(\mu \mathrm{mho} / \mathrm{cm} \\
\left(225^{\circ} \mathrm{C}\right)\end{array}$ \\
\hline I NOI & 4 & $<0.1$ & 9 & $<10$ & 0.12 & 0.4 & $<0.2$ & 11 & 5 & $<0.1$ & 0.044 & 2.90 & 1.7 & $<6$ & 29 & 0.071 & 0.095 & 17.0 \\
\hline IN04 & 7 & 0.1 & 15 & $<10$ & 0.61 & 1.0 & 0.2 & 7 & 5 & $<0.1$ & 0.059 & 5.30 & 2.7 & $<6$ & 39 & 0.170 & 0.190 & 32.0 \\
\hline IN17 & 5 & 0.1 & 14 & $<10$ & 0.61 & 1.0 & 0.2 & $<1$ & 4 & $<0.1$ & 0.180 & 5.80 & 4.1 & $<6$ & 39 & 0.165 & 0.211 & 35.0 \\
\hline IN10 & 7 & $<0.1$ & 8 & $<30$ & 0.65 & 0.6 & $<0.2$ & 1 & 2 & $<0.1$ & 0.190 & 4.20 & 3.3 & $<6$ & 14 & 0.129 & 0.136 & 25.0 \\
\hline IN13 & 5 & 0.1 & 13 & $<10$ & 0.60 & 0.8 & 0.2 & $<1$ & 4 & $<0.1$ & 0.150 & 5.90 & 5.5 & $<6$ & 24 & 0.185 & 0.187 & 22.0 \\
\hline I N07 & 5 & $<0.1$ & 12 & $<10$ & 0.50 & 0.8 & $<0.2$ & 2 & 4 & $<0.1$ & 0.470 & 4.40 & 5.8 & $<6$ & 84 & 0.146 & 0.156 & 31.0 \\
\hline MI20 & 4 & $<0.1$ & 7 & $<10$ & 0.60 & 1.0 & $<0.2$ & 1 & 12 & $<0.1<$ & $<0.009$ & 3.30 & 1.7 & $<6$ & 96 & 0.153 & 0.191 & 42.0 \\
\hline MI21 & 22 & 0.2 & 8 & $<10$ & 0.60 & 0.9 & 0.2 & $<1$ & 9 & $<0.1$ & 0.097 & 3.10 & 2.9 & $<6$ & 6 & 0.180 & 0.135 & 38.0 \\
\hline MI 22A & 20 & 0.1 & 10 & $<10$ & 0.89 & 1.6 & $<0.2$ & $<1$ & 21 & $<0.1$ & 0.210 & 3.40 & 3.9 & $<6$ & 33 & 0.213 & 0.200 & 55.0 \\
\hline MI 22B & 24 & $<0.1$ & 4 & $<10$ & 0.22 & 0.5 & $<0.2$ & $<1$ & 9 & $<0.1$ & 0.083 & 2.00 & 1.9 & $<6$ & 6 & 0.130 & 0.082 & 18.0 \\
\hline MI 22C & 21 & $<0.1$ & 14 & $<10$ & 1.30 & 1.3 & 0.2 & $<1$ & 17 & $<0.1$ & 0.099 & 4.70 & 3.3 & $<6$ & 16 & 0.208 & 0.202 & 41.0 \\
\hline MI 22D & 23 & $<0.1$ & 6 & $<10$ & 0.57 & 0.8 & $<0.2$ & $<1$ & 8 & $<0.1$ & 0.110 & 3.70 & 3.1 & $<6$ & 5 & 0.128 & 0.144 & 33.0 \\
\hline WI 28 & 21 & 0.2 & 8 & $<10$ & 1.40 & 1.0 & 0.4 & 1 & 4 & $<0.1$ & 0.270 & 5.20 & 4.1 & $<6$ & 41 & 0.198 & 0.203 & 28.0 \\
\hline MI 26 & 13 & $<0.1$ & 5 & $<10$ & 0.38 & 0.7 & $<0.2$ & 5 & 9 & $<0.1$ & 0.220 & 2.40 & 3.2 & $<6$ & 6 & 0.111 & 0.104 & 31.0 \\
\hline MI 27 & 19 & $<0.1$ & 4 & $<10$ & 0.35 & 0.7 & $<0.2$ & 1 & 5 & $<0.1$ & 0.035 & 2.40 & 1.9 & $<6$ & 12 & 0.104 & 0.113 & 29.0 \\
\hline IL10 & 8 & $<0.1$ & 13 & $<10$ & 0.93 & 0.9 & $<0.2$ & 2 & 3 & $<0.1$ & 0.050 & 6.00 & 2.4 & $<6$ & 18 & 0.158 & 0.201 & 28.0 \\
\hline IL15 & 6 & 0.2 & 24 & $<10$ & 0.52 & 0.9 & 0.2 & 1 & 1 & $<0.1$ & 0.056 & 5.40 & 2.8 & $<6$ & 18 & 0.167 & 0.191 & 25.0 \\
\hline ILO9 & $<4$ & 0.1 & 20 & $<10$ & 0.68 & 1.0 & $<0.2$ & 2 & 3 & $<0.1$ & 0.034 & 6.60 & 2.8 & $<6$ & 20 & 0.159 & 0.225 & 26.0 \\
\hline IL20 & 7 & 0.1 & 24 & $<10$ & 1.70 & 1.5 & $<0.2$ & $<1$ & 3 & $<0.1$ & 0.014 & 4.60 & 3.3 & $<6$ & 16 & 0.201 & 0.220 & 30.0 \\
\hline IL24 & 5 & 0.2 & 22 & $<10$ & 1.70 & 1.6 & $<0.2$ & $<1$ & 2 & $<0.1$ & 0.018 & 4.10 & 3.1 & $<6$ & 16 & 0.209 & 0.208 & 29.0 \\
\hline IL16 & $<4$ & 0.1 & 19 & $<10$ & 0.58 & 0.9 & 0.2 & 1 & 4 & $<0.1$ & 0.067 & 5.90 & 3.0 & $<6$ & 31 & 0.173 & 0.198 & 28.0 \\
\hline IL2l & $<4$ & 0.1 & 28 & $<10$ & 0.55 & 0.8 & $<0.2$ & $<1$ & $<1$ & $<0.1$ & 0.040 & 4.50 & 3.2 & $<6$ & 19 & 0.148 & 0.158 & 22.0 \\
\hline WI 27 & 21 & 0.5 & 15 & $<10$ & 0.98 & 1.2 & 0.4 & 1 & 2 & $<0.1$ & 0.240 & 5.20 & 4.3 & $<6$ & 21 & 0.207 & 0.207 & 25.0 \\
\hline WI09 & 28 & $<0.1$ & 1 & $<10$ & 0.08 & 0.1 & $<0.2$ & $<1$ & 1 & $<0.1$ & 0.100 & 0.71 & 2.1 & $<6$ & $<3$ & 0.024 & 0.028 & 1.5 \\
\hline WI 12 & 32 & 0.1 & 10 & $<10$ & 0.58 & 0.7 & $<0.2$ & 1 & 6 & $<0.1$ & 0.140 & 3.10 & 2.6 & $<6$ & 12 & 0.121 & 0.124 & 22.0 \\
\hline MI 25 & 24 & $<0.1$ & 3 & $<10$ & 0.27 & 0.5 & $<0.2$ & $<1$ & 3 & $<0.1$ & 0.083 & 1.70 & 1.9 & $<6$ & 3 & 0.070 & 0.073 & 19.0 \\
\hline MI 24 & 24 & $<0.1$ & 4 & $<10$ & 0.37 & 0.6 & 0.3 & $<1$ & 5 & $<0.1$ & 0.450 & 2.30 & 4.9 & $<6$ & $<3$ & 0.108 & 0.096 & 26.0 \\
\hline WI 26 & 23 & 0.2 & 16 & $<10$ & 0.70 & 0.8 & 0.2 & $<1$ & 4 & $<0.1$ & 0.160 & 4.20 & 3.8 & $<6$ & 9 & 0.145 & 0.187 & 21.0 \\
\hline IL22 & 5 & $<0.1$ & 17 & $<10$ & 0.37 & 0.7 & $<0.2$ & 1 & 4 & $<0.1$ & 0.054 & 3.30 & 3.1 & $<6$ & 21 & 0.128 & 0.125 & 21.0 \\
\hline IL08 & $<4$ & 0.2 & 19 & $<10$ & 0.68 & 0.8 & $<0.2$ & 1 & 6 & $<0.1$ & 0.060 & 6.10 & 2.9 & $<6$ & 23 & 0.161 & 0.196 & 23.0 \\
\hline IL25 & 6 & 0.3 & 17 & $<10$ & 0.66 & 0.8 & $<0.2$ & $<1$ & 3 & $<0.1$ & 0.078 & 4.90 & 2.9 & $<6$ & 27 & 0.178 & 0.173 & 25.0 \\
\hline IL11 & 5 & $<0.1$ & 24 & $<10$ & 0.44 & 0.8 & 0.2 & l & 2 & $<0.1$ & 0.055 & 5.20 & 3.2 & $<6$ & 41 & 0.145 & 0.179 & 23.0 \\
\hline IL23 & 4 & 0.2 & 21 & $<10$ & 0.44 & 0.8 & 0.3 & l & 2 & $<0.1$ & 0.058 & 3.50 & 2.7 & $<6$ & 19 & 0.156 & 0.145 & 22.0 \\
\hline IL17 & $<4$ & $<0.1$ & 16 & $<10$ & 0.98 & 1.0 & $<0.2$ & $<1$ & 4 & $<0.1$ & 0.048 & 7.20 & 3.0 & $<6$ & 25 & 0.166 & 0.232 & 30.0 \\
\hline MI 23 & 28 & $<0.1$ & 3 & $<10$ & 0.21 & 0.3 & $<0.2$ & $<1$ & 2 & $<0.1$ & 0.290 & 1.50 & 3.1 & $<6$ & $<3$ & 0.065 & 0.055 & 13.0 \\
\hline WL 08 & 28 & $<0.1$ & 7 & $<10$ & 0.51 & 0.6 & $<0.2$ & $<1$ & 5 & $<0.1$ & 0.130 & 3.10 & 2.8 & $<6$ & 6 & 0.103 & 0.115 & 18.0 \\
\hline WI 14 & 32 & $<0.1$ & 1 & $<10$ & 0.10 & 0.2 & $<0.2$ & $<1$ & $<1$ & $<0.1$ & 0.130 & 0.37 & 2.1 & $<6$ & $<3$ & 0.032 & 0.026 & 3.9 \\
\hline WI 15 & 17 & $<0.1$ & 3 & $<10$ & 0.25 & 0.4 & $<0.2$ & $<1$ & 1 & $<0.1$ & 0.510 & 1.60 & 5.0 & $<6$ & $<3$ & 0.072 & 0.065 & 12.0 \\
\hline WI 16A & $<4$ & $<0.1$ & 1 & $<10$ & 0.07 & 0.1 & $<0.2$ & $<1$ & 2 & $<0.1$ & 0.400 & 0.42 & 2.3 & $<6$ & $<3$ & 0.135 & 0.023 & 3.4 \\
\hline WI 16B & 16 & $<0.1$ & 10 & $<10$ & 0.48 & 0.9 & $<0.2$ & $<1$ & 7 & $<0.1$ & 0.200 & 2.60 & 3.7 & $<6$ & 30 & 0.142 & 0.127 & 24.0 \\
\hline WI 16C & 16 & 0.1 & 4 & $<10$ & 0.24 & 0.5 & $<0.2$ & $<1$ & 6 & $<0.1$ & 0.095 & 1.30 & 2.2 & $<6$ & 5 & 0.122 & 0.073 & 12.0 \\
\hline WI 16D & 19 & 0.1 & 3 & $<10$ & 0.16 & 0.6 & $<0.2$ & 1 & 8 & $<0.1$ & 0.350 & 1.40 & 3.7 & $<6$ & 5 & 0.043 & 0.078 & 16.0 \\
\hline WI 17 & 18 & 0.1 & 2 & $<10$ & 0.15 & 0.3 & $<0.2$ & $<1$ & 3 & $<0.1$ & 0.110 & 1.00 & 2.2 & $<6$ & $<3$ & 0.056 & 0.046 & 7.1 \\
\hline WI 29 & 21 & 0.1 & 1 & $<10$ & 0.08 & 0.1 & $<0.2$ & $<1$ & 1 & $<0.1$ & 0.150 & 0.48 & 2.3 & $<6$ & $<3$ & 0.036 & 0.025 & 2.2 \\
\hline WI 32 & 20 & $<0.1$ & 4 & $<10$ & 0.27 & 0.4 & $<0.2$ & 1 & 2 & $<0.1$ & 0.160 & 1.30 & 2.3 & $<6$ & 7 & 0.062 & 0.063 & 9.6 \\
\hline WI 13 & 34 & $<0.1$ & 2 & $<10$ & 0.17 & 0.2 & 0.3 & 1 & 2 & $<0.1$ & 0.150 & 1.10 & 2.2 & $<6$ & 22 & 0.048 & 0.061 & 5.0 \\
\hline WIOI & 32 & 0.3 & 12 & $<10$ & 0.59 & 0.7 & 0.2 & 2 & 3 & $<0.1$ & 0.200 & 3.40 & 4.5 & $<6$ & 9 & 0.134 & 0.129 & 18.0 \\
\hline WIO2 & 38 & 0.2 & 13 & $<10$ & 0.43 & 0.5 & $<0.2$ & $<1$ & 1 & $<0.1$ & 0.340 & 3.10 & 4.0 & $<6$ & 8 & 0.100 & 0.106 & 14.0 \\
\hline WI 30 & 23 & 0.3 & 13 & $<10$ & 0.60 & 0.8 & 0.2 & 1 & 2 & $<0.1$ & 0.340 & 3.60 & 5.1 & $<6$ & 8 & 0.151 & 0.143 & 16.0 \\
\hline W107 & 31 & $<0.1$ & 20 & $<10$ & 0.62 & 0.9 & 0.2 & $<1$ & 3 & $<0.1$ & 0.120 & 4.30 & 3.4 & $<6$ & 19 & 0.136 & 0.163 & 26.0 \\
\hline
\end{tabular}


TABLE 5. - Dissolved chemical constituent

\begin{tabular}{|c|c|c|c|c|c|c|c|c|c|c|c|c|c|c|c|c|c|c|}
\hline $\begin{array}{l}\text { Lat1- } \\
\text { tude }\end{array}$ & $\begin{array}{l}\text { Long1- } \\
\text { tude }\end{array}$ & $\begin{array}{l}\text { Labora- } \\
\text { tory } \\
\text { Iden- } \\
\text { tifi- } \\
\text { cation } \\
\text { number }\end{array}$ & $\begin{array}{l}\text { Split } \\
\text { sample } \\
\text { iden } \\
\text { tifi- } \\
\text { cation } \\
\text { number }\end{array}$ & $\begin{array}{c}\text { Sample } \\
\text { type }\end{array}$ & $\begin{array}{c}\text { As } \\
\left(\mu_{\mathrm{g}} / \mathrm{L}\right)\end{array}$ & $\begin{array}{c}\mathrm{Ba} \\
(\mu \mathrm{g} / \mathrm{L})\end{array}$ & $\frac{\mathrm{Be}}{\left(\mu_{\mathrm{g}} / \mathrm{L}\right)}$ & $\begin{array}{c}\text { Total } \\
\text { inorganic } \\
\text { carbon } \\
(\mathrm{mg} / \mathrm{L})\end{array}$ & $\begin{array}{c}\mathrm{Ca} \\
(\mathrm{mg} / \mathrm{L})\end{array}$ & $\begin{array}{c}\mathrm{Cd} \\
(\mu \mathrm{g} / \mathrm{L})\end{array}$ & $\begin{array}{c}\mathrm{Cl} \\
(\mathrm{mg} / \mathrm{L})\end{array}$ & $\begin{array}{c}\text { Co } \\
(\mu \mathrm{g} / \mathrm{L})\end{array}$ & $\begin{array}{c}C u \\
(\mu g / L)\end{array}$ & $\underset{(\mathrm{mg} / \mathrm{L})}{\mathrm{F}}$ & $\begin{array}{c}\mathrm{Fe} \\
(\mu \mathrm{g} / \mathrm{L})\end{array}$ & $\begin{array}{c}\mathrm{pH} \\
(\mu \mathrm{g} / \mathrm{L})\end{array}$ & $\begin{array}{c}\mathrm{Hg} \\
(\mu \mathrm{g} / \mathrm{L})\end{array}$ & $\begin{array}{c}\mathrm{K} \\
(\mathrm{mg} / \mathrm{L})\end{array}$ \\
\hline 410816 & 895452 & IL19 & & P & 1.0 & $<2$ & $<0.5$ & 3.1 & 1.30 & 55 & 3.00 & $<3$ & 50 & 0.06 & 14 & 6.7 & 0.1 & 2.8 \\
\hline 435732 & 895659 & WIO6 & & $\mathrm{P}$ & 1.0 & 3 & $<0.5$ & 0.4 & 1.20 & $<1$ & 0.44 & 3 & $<10$ & 0.06 & 37 & 5.3 & $<0.1$ & 0.2 \\
\hline 435732 & 895659 & WI 31 & WI06 & $z$ & 1.0 & $<2$ & $<0.5$ & 0.4 & 1.20 & $<1$ & 0.39 & $<3$ & $<10$ & 0.04 & 36 & 5.1 & $<0.1$ & 0.2 \\
\hline 392325 & 895836 & IL 18 & & P & 1.0 & 4 & $<0.5$ & 0.4 & 1.90 & 3 & 0.46 & $<3$ & $<10$ & 0.06 & 38 & 4.7 & $<0.1$ & 0.1 \\
\hline 452802 & 895846 & WI 11 & & P & .1 .0 & 4 & $<0.5$ & 0.4 & 0.66 & $<1$ & 0.41 & $<3$ & $<10$ & 0.13 & 30 & 4.3 & 0.3 & 0.1 \\
\hline 460743 & 901111 & WI 18 & & $\mathbf{P}$ & $<0.1$ & $<2$ & $<0.5$ & 0.4 & 0.14 & $<1$ & 0.11 & $<3$ & $<10$ & 0.13 & 22 & 4.5 & 0.2 & $<0.1$ \\
\hline 445528 & 901228 & WI 10 & & P & $<0.1$ & 2 & $<0.5$ & 0.4 & 0.77 & $<1$ & 0.26 & $<3$ & $<10$ & 0.10 & 38 & 4.3 & 0.2 & $<0.1$ \\
\hline 480235 & 902842 & MN21 & & p & $<0.1$ & $<2$ & $<0.5$ & 0.4 & 0.08 & 3 & 0.26 & $<3$ & 20 & 0.04 & 22 & 5.2 & 0.1 & $<0.1$ \\
\hline 480235 & 902842 & MN31 & IIN21 & 2 & $<0.1$ & $<2$ & $<0.5$ & 0.4 & 0.11 & $<1$ & 0.62 & $<3$ & $<10$ & 0.07 & 62 & 5.2 & $<0.1$ & 0.1 \\
\hline 424413 & 903834 & WI04 & & P & 1.0 & 3 & $<0.5$ & 1.0 & 1.90 & $<1$ & 0.39 & $<3$. & $<10$ & 0.05 & 8 & 6.3 & $<0.1$ & 0.2 \\
\hline 433418 & 903853 & WIOS & & $\mathrm{p}$ & $<0.1$ & 3 & $<0.5$ & 0.6 & 1.70 & $<1$ & 0.83 & $<3$ & $<10$ & 0.05 & 17 & 6.2 & 0.1 & 0.1 \\
\hline 465426 & 905351 & WI 25 & & P & 1.0 & $<2$ & $<0.5$ & 0.4 & 0.35 & $<1$ & 0.28 & $<3$ & $<10$ & 0.08 & $2 I$ & 4.3 & $<0.1$ & $<0.1$ \\
\hline 452011 & 905814 & WI22 & & $\mathrm{P}$ & $<0.1$ & $<2$ & $<0.5$ & 0.4 & 0.43 & $<1$ & 0.29 & $<3$ & $<10$ & 0.13 & 16 & 4.9 & 0.1 & 0.1 \\
\hline 444942 & 905857 & WI 20 & & $\mathrm{P}$ & $<0.1$ & 2 & $<0.5$ & 0.4 & 1.30 & $<1$ & 0.58 & $<3$ & $<10$ & 0.38 & 32 & 4.3 & 0.2 & 0.1 \\
\hline 440715 & 912140 & WI19 & & p & $<0.1$ & 3 & $<0.5$ & 0.6 & 2.40 & $<1$ & 0.53 & $<3$ & $<10$ & 0.20 & 18 & 4.2 & $<0.1$ & 0.1 \\
\hline 475800 & 912905 & MN20 & & P & $<0.1$ & $<2$ & $<0.5$ & 0.8 & 0.30 & 3 & 0.19 & $<3$ & 10 & 0.07 & 15 & 5.4 & $<0.1$ & $<0.1$ \\
\hline 463207 & 913454 & WI 24 & & P & 1.0 & 2 & $<0.5$ & 0.4 & 0.58 & $<1$ & 0.27 & 4 & $<10$ & 0.09 & 39 & 4.6 & 0.1 & $<0.1$ \\
\hline 454920 & 915229 & WI 23 & & P & 1.0 & 2 & $<0.5$ & 0.4 & 0.87 & $<1$ & 0.36 & $<3$ & $<10$ & 0.12 & 22 & 5.0 & 0.1 & 0.1 \\
\hline 454920 & 915229 & WI 33 & WI 23 & 2 & $<0.1$ & 3 & $<0.5$ & 0.4 & 0.76 & $<1$ & 0.49 & $<3$ & $<10$ & 0.29 & 15 & 4.6 & 0.1 & 0.1 \\
\hline 450320 & 915606 & WI 21 & & p & 1.0 & 3 & $<0.5$ & 0.4 & 1.80 & $<1$ & 0.45 & 4 & $<10$ & 0.64 & 29 & 6.3 & 0.1 & 0.2 \\
\hline 470642 & 915911 & MN12 & & $\mathrm{P}$ & 1.0 & $<2$ & $<0.5$ & 0.4 & 0.31 & 1 & 0.14 & 3 & 20 & 0.03 & 27 & 4.5 & $<0.1$ & $<0.2$ \\
\hline 463113 & 923303 & MN1 1 & & P & $<0.1$ & $<2$ & $<0.5$ & 0.4 & 0.54 & 29 & 0.20 & 3 & 100 & 0.04 & 22 & 4.9 & $<0.1$ & $<0.1$ \\
\hline 455531 & 931726 & MNOS & & p & $<0.1$ & 4 & $<0.5$ & 0.6 & 2.60 & $<1$ & 0.49 & $<3$ & $<10$ & 0.07 & 17 & 6.1 & $<0.1$ & $<0.1$ \\
\hline 455531 & 931726 & $M N 30$ & MNO5 & Z & $<0.1$ & 2 & $<0.5$ & 0.6 & 1.50 & $<1$ & 0.54 & $<3$ & $<10$ & 0.06 & 20 & 6.2 & $<0.1$ & 0.1 \\
\hline 472807 & 933153 & MN26 & & $\mathrm{P}$ & $<0.1$ & $<2$ & $<0.5$ & 0.4 & 0.53 & $<1$ & 0.66 & $<3$ & 10 & 0.06 & 10 & 5.7 & $<0.1$ & $<0.1$ \\
\hline 472807 & 933153 & MN25 & & $\mathrm{R}$ & $<0.1$ & $<2$ & $<0.5$ & 0.6 & 0.21 & 2 & 0.45 & $<3$ & 20 & 0.05 & 11 & 6.3 & $<0.1$ & 0.1 \\
\hline 472807 & 933153 & MN1 $3 \mathrm{~A}$ & & A & $<0.1$ & 2 & $<0.5$ & 0.2 & 0.56 & 2 & 0.22 & $<3$ & 10 & 0.03 & 17 & 5.2 & 0.1 & 0.1 \\
\hline 472807 & 933153 & $\operatorname{MN} 13 B$ & & c & $<0.1$ & $<2$ & $<0.5$ & 0.4 & 0.64 & 2 & 0.33 & 4 & 10 & 0.07 & 22 & 4.7 & $<0.1$ & $<0.1$ \\
\hline 472807 & 933153 & MN1 3C & & D & 1.0 & 3 & $<0.5$ & 0.4 & 1.30 & $<1$ & 0.39 & 3 & 30 & 0.08 & 86 & 4.9 & 0.1 & $<0.1$ \\
\hline 472807 & 933153 & MN27 & & $\mathrm{s}$ & $<0.1$ & $<2$ & $<0.5$ & 0.4 & 0.22 & $<1$ & 0.29 & $<3$ & 10 & 0.05 & 19 & 5.1 & $<0.1$ & $<0.1$ \\
\hline 472807 & 933153 & MN33 & MN13D & 2 & $<0.1$ & 2 & $<0.5$ & 0.4 & 0.92 & $<1$ & 0.34 & 3 & 10 & 0.08 & 63 & 4.7 & $<0.1$ & 0.1 \\
\hline 444205 & 933927 & MNO4 & & $\mathrm{p}$ & $<0.1$ & 4 & $<0.5$ & 1.4 & 3.40 & $<1$ & 0.65 & $<3$ & $<10$ & 0.08 & 14 & 6.6 & $<0.1$ & 0.1 \\
\hline 444205 & 933927 & MN28 & & $\mathrm{R}$ & $<0.1$ & 4 & $<0.5$ & 1.2 & 2.90 & $<1$ & 0.77 & $<3$ & $<10$ & 0.07 & 12 & 6.6 & $<0.1$ & 0.1 \\
\hline 483622 & 935147 & MN22 & & $\mathrm{p}$ & 1.0 & 3 & $<0.5$ & 0.4 & 0.93 & 3 & 0.23 & $<3$ & 20 & 0.04 & 29 & 4.7 & $<0.1$ & 0.1 \\
\hline 474607 & 935156 & MN19 & & $P$ & $<0.1$ & $<2$ & $<0.5$ & 0.4 & 0.60 & 2 & 0.25 & $<3$ & 10 & 0.04 & 17 & 4.8 & $<0.1$ & $<0.1$ \\
\hline 463254 & 941431 & MN10 & & P & $<0.1$ & 2 & $<0.5$ & 0.8 & 2.00 & 4 & 0.53 & $<3$ & 20 & 0.10 & 17 & 5.8 & $<0.1$ & $<0.1$ \\
\hline 463254 & 941431 & $\operatorname{MN} 34$ & MN10 & z & $<0.1$ & 2 & $<0.5$ & 0.8 & 1.50 & $<1$ & 0.30 & $<3$ & $<10$ & 0.08 & 8 & 6.3 & 0.1 & 0.1 \\
\hline 470251 & 941526 & MN14 & & P & $<0.1$ & 2 & $<0.5$ & 0.4 & 1.20 & $<1$ & 0.39 & $<3$ & $<10$ & 0.06 & 16 & 5.6 & $<0.1$ & 0.1 \\
\hline 451038 & 941800 & MNO3 & & P & 3.0 & 5 & $<0.5$ & 2.1 & 4.50 & $<1$ & 0.64 & $<3$ & $<10$ & 0.09 & 18 & 7.0 & $<0.1$ & 0.2 \\
\hline 455142 & 942130 & MNO6 & & P & $<0.1$ & 4 & $<0.5$ & 0.8 & 2.80 & $<1$ & 0.39 & $<3$ & $<10$ & 0.08 & 10 & 6.4 & $<0.1$ & 0.1 \\
\hline 484307 & 945355 & MN23 & & $\mathrm{P}$ & 1.0 & 3 & $<0.5$ & 0.4 & 1.30 & $<1$ & 0.22 & $<3$ & $<10$ & 0.04 & 11 & 5.7 & $<0.1$ & $<0.1$ \\
\hline 472610 & 951548 & MN15 & & P & 1.0 & 3 & $<0.5$ & 0.4 & 2.90 & 7 & 0.54 & $<3$ & 50 & 0.08 & 27 & 5.6 & $<0.1$ & 0.2 \\
\hline 472610 & 951548 & MN29 & MN15 & 2 & 1.0 & 3 & $<0.5$ & 0.4 & 2.20 & 6 & 0.57 & $<3$ & 50 & 0.07 & 14 & 5.6 & $<0.1$ & 0.2 \\
\hline 463108 & 951654 & MNO9 & & $\mathrm{P}$ & 1.0 & 9 & $<0.5$ & 4.3 & 8.60 & $<1$ & 0.74 & 3 & 10 & 0.13 & 16 & 6.4 & $<0.1$ & 0.2 \\
\hline 451253 & 951934 & MNO2 & & $\mathbf{P}$ & 4.0 & 11 & $<0.5$ & 5.3 & 10.30 & $<1$ & 0.80 & $<3$ & 10 & 0.11 & 10 & 7.2 & $<0.1$ & 0.3 \\
\hline 481545 & 952418 & MN18 & & p & $<0.1$ & 2 & $<0.5$ & 0.6 & 2.30 & 6 & 0.30 & 3 & 20 & 0.06 & 11 & 6.3 & 0.1 & 0.1 \\
\hline 453954 & 952633 & MNO7 & & $\mathrm{P}$ & 1.0 & 8 & $<0.5$ & 4.7 & 9.10 & $<1$ & 0.92 & $<3$ & $<10$ & 0.16 & 6 & 7.3 & $<0.1$ & 0.3 \\
\hline 453021 & 961234 & MNO1 & & P & 1.0 & 14 & $<0.5$ & 0.4 & 12.10 & $<1$ & 0.28 & $<3$ & 10 & 0.07 & 15 & 7.0 & $<0.1$ & 0.7 \\
\hline 462235 & 961455 & MNO8 & & $\mathrm{p}$ & 1.0 & 27 & $<0.5$ & 4.0 & 30.30 & $<1$ & 1.20 & $<3$ & 10 & 0.13 & 10 & 7.4 & 0.1 & 0.7 \\
\hline 471331 & 961746 & MN16 & & $\mathrm{P}$ & 1.0 & 30 & $<0.5$ & 8.6 & 40.80 & 2 & 0.69 & $<3$ & 20 & 0.16 & 71 & 7.9 & $<0.1$ & 0.9 \\
\hline 485804 & 962656 & MN24 & & P & 1 & 3 & $<0.5$ & 1.2 & 3.4 & $<1$ & 0.80 & $<3$ & $<10$ & 0.07 & 17 & 6.7 & $<0.1$ & 0.2 \\
\hline 485804 & 962656 & MN32 & MN24 & z & 1 & 2 & $<0.5$ & 1.2 & 3.0 & $<1$ & 0.58 & $<3$ & $<10$ & 0.06 & 13 & 6.7 & $<0.1$ & 0.1 \\
\hline 480718 & 964005 & MN17 & & $\mathrm{P}$ & 1 & 14 & $<0.5$ & 6.6 & 28.6 & 10 & 1.40 & 3 & 30 & 0.13 & 44 & 7.9 & 0.1 & 1.3 \\
\hline
\end{tabular}


concentrations of bulk-precipitation samples-Continued

\begin{tabular}{|c|c|c|c|c|c|c|c|c|c|c|c|c|c|c|c|c|c|c|}
\hline $\begin{array}{l}\text { Labora- } \\
\text { tory } \\
\text { iden- } \\
\text { tifi- } \\
\text { cation } \\
\text { number }\end{array}$ & $\begin{array}{c}\mathrm{Lf} \\
\left(\mu_{\mathrm{g}} / \mathrm{L}\right)\end{array}$ & $\underset{(\mathrm{mg} / \mathrm{L})}{\mathrm{Mg}}$ & $\begin{array}{c}M \mathrm{n} \\
(\mu \mathrm{g} / \mathrm{L})\end{array}$ & $\begin{array}{c}\text { Mo } \\
(\mu \mathrm{g} / \mathrm{L})\end{array}$ & $\begin{array}{l}\mathrm{NH}_{4}-\mathrm{N} \\
(\mathrm{mg} / \mathrm{L})\end{array}$ & $\begin{array}{r}\mathrm{NO}_{3}-\mathrm{N} \\
(\mathrm{mg} / \mathrm{L})\end{array}$ & $\begin{array}{c}\mathrm{Na} \\
(\mathrm{mg} / \mathrm{L})\end{array}$ & $\begin{array}{c}\text { Ni } \\
(\mu g / L)\end{array}$ & $\begin{array}{c}\mathrm{Pb} \\
(1 \mathrm{~g} / \mathrm{L})\end{array}$ & $\begin{array}{c}\mathrm{Se} \\
(\mu \mathrm{g} / \mathrm{L})\end{array}$ & $\begin{array}{c}\mathrm{Si} \\
(\mu \mathrm{g} / \mathrm{L})\end{array}$ & $\begin{array}{c}\mathrm{SO}_{4} \\
(\mathrm{~m} / \mathrm{L})\end{array}$ & $\begin{array}{c}\mathrm{Sr} \\
(\mathrm{Hg} / \mathrm{L})\end{array}$ & $\begin{array}{c}v \\
(\mu g / L)\end{array}$ & $\begin{array}{c}\mathrm{Zn} \\
(\mu \mathrm{g} / \mathrm{L})\end{array}$ & $\begin{array}{c}\text { Cations } \\
\text { sum } \\
\text { (meq/L) }\end{array}$ & $\begin{array}{c}\text { Anions } \\
\text { sum } \\
\text { (meq/L) }\end{array}$ & $\begin{array}{c}\text { Specif } 1 \mathrm{c} \\
\text { conductance } \\
(\mu \mathrm{mho} / \mathrm{cm} \\
\left(225^{\circ} \mathrm{C}\right)\end{array}$ \\
\hline IL19 & $<4$ & $<0.1$ & 15 & $<10$ & 3.70 & 0.6 & 1.4 & $<1$ & $<1$ & $<0.1$ & 0.047 & 5.30 & 3.2 & $<6$ & 66 & 0.390 & 0.238 & 55.0 \\
\hline WI06 & 35 & 0.5 & 16 & $<10$ & 1.10 & 1.0 & 0.2 & 1 & 4 & $<0.1$ & 0.720 & 5.00 & 5.0 & $<6$ & 42 & 0.193 & 0.188 & 28.0 \\
\hline WI 31 & 17 & 0.4 & 16 & $<10$ & 1.10 & 1.0 & 0.2 & 1 & 3 & $<0.1$ & 0.720 & 5.00 & 4.6 & $<6$ & 42 & 0.188 & 0.186 & 23.0 \\
\hline IL18 & $<4$ & $<0.1$ & 19 & $<10$ & 0.72 & 0.9 & 0.2 & $<1$ & 5 & $<0.1$ & 0.067 & 7.40 & 3.5 & $<6$ & 30 & 0.175 & 0.231 & 26.0 \\
\hline WI11 & 28 & $<0.1$ & 7 & $<10$ & 0.64 & 0.9 & $<0.2$ & $<1$ & 6 & $<0.1$ & 0.150 & 3.60 & 3.2 & $<6$ & 20 & 0.129 & 0.151 & 26.0 \\
\hline W1 18 & 16 & $<0.1$ & 2 & $<10$ & 0.12 & 0.3 & $<0.2$ & $<1$ & 4 & $<0.1$ & 0.110 & 0.94 & 2.1 & $<6$ & 6 & 0.047 & 0.044 & 7.8 \\
\hline WI 10 & 32 & $<0.1$ & 9 & $<10$ & 0.47 & 0.5 & $<0.2$ & $<1$ & 3 & $<0.1$ & 0.150 & 2.70 & 2.8 & $<6$ & 19 & 0.122 & 0.099 & 20.0 \\
\hline MN21 & 31 & 0.1 & 1 & $<10$ & 0.05 & 0.1 & $<0.2$ & 3 & 1 & $<0.1$ & 0.079 & 0.23 & 1.9 & $<6$ & $<3$ & 0.022 & 0.019 & 0.3 \\
\hline MN31 & $<4$ & $<0.1$ & 1 & $<10$ & 0.05 & 0.1 & $<0.2$ & 2 & 4 & $<0.1$ & 0.310 & 0.37 & 3.3 & $<6$ & $<3$ & 0.015 & 0.032 & 1.1 \\
\hline WI 04 & 36 & 0.5 & 16 & $<10$ & 1.50 & 0.9 & 0.2 & $<1$ & 2 & $<0.1$ & 0.170 & 5.40 & 4.5 & $<6$ & 26 & 0.252 & 0.187 & 32.0 \\
\hline WI05 & 33 & 0.5 & 16 & $<10$ & 0.76 & 0.9 & 0.5 & $<1$ & 2 & $<0.1$ & 0.660 & 4.20 & 7.4 & $<6$ & 71 & 0.203 & 0.175 & 25.0 \\
\hline WI 25 & 20 & $<0.1$ & 5 & $<10$ & 0.37 & 0.6 & $<0.2$ & 1 & 3 & $<0.1$ & 0.310 & 2.10 & 3.8 & $<6$ & 8 & 0.094 & 0.094 & 2.0 \\
\hline WI 22 & 19 & $<0.1$ & 5 & $<10$ & 0.37 & 0.3 & $<0.2$ & $<1$ & 4 & $<0.1$ & 0.340 & 1.50 & 4.1 & $<6$ & 12 & 0.060 & 0.061 & 5.7 \\
\hline WI 20 & 12 & 0.1 & 16 & $<10$ & 0.96 & 1.1 & 0.2 & $<1$ & 5 & $<0.1$ & 0.140 & 4.30 & 4.4 & $<6$ & 28 & 0.200 & 0.184 & 25.0 \\
\hline WI 19 & 18 & 0.3 & 15 & $<10$ & 0.72 & 0.8 & 0.2 & $<1$ & 5 & $<0.1$ & 0.170 & 3.80 & 5.0 & $<6$ & 59 & 0.268 & 0.151 & 22.0 \\
\hline MN2O & 30 & $<0.1$ & 4 & $<10$ & 0.23 & 0.2 & $<0.2$ & 3 & 4 & $<0.1$ & 0.093 & 0.88 & 2.4 & $<6$ & $<3$ & 0.035 & 0.038 & 3.4 \\
\hline WI 24 & 20 & $<0.1$ & 8 & $<10$ & 0.32 & 0.5 & $<0.2$ & $<1$ & 8 & $<0.1$ & 0.180 & 2.00 & 3.8 & $<6$ & 21 & 0.077 & 0.085 & 11.0 \\
\hline WI 23 & 23 & $<0.1$ & 11 & $<10$ & 0.59 & 0.7 & 0.2 & $<1$ & 5 & $<0.1$ & 0.600 & 2.50 & 6.6 & $<6$ & 10 & 0.104 & 0.112 & 16.0 \\
\hline WI 33 & 16 & $<0.1$ & 10 & $<10$ & 0.56 & 0.7 & 0.2 & 1 & 2 & $<0.1$ & 0.340 & 2.60 & 4.4 & $<6$ & 9 & 0.112 & 0.118 & 14.0 \\
\hline WI 21 & 14 & 0.3 & 23 & $<10$ & 0.82 & 1.2 & 0.2 & $<1$ & 3 & $<0.1$ & 0.190 & 4.40 & 5.0 & $<6$ & 31 & 0.182 & 0.190 & 29.0 \\
\hline MN12 & 31 & $<0.1$ & 8 & $<10$ & 0.24 & 0.2 & $<0.2$ & 2 & 1 & $<0.1$ & 0.140 & 0.85 & 2.7 & $<6$ & $<3$ & 0.064 & 0.036 & 3.3 \\
\hline MN11 & 31 & $<0.1$ & 5 & $<10$ & 0.19 & 0.2 & $<0.2$ & 1 & 1 & $<0.1$ & 0.082 & 0.87 & 2.3 & $<6$ & 22 & 0.053 & 0.038 & 3.3 \\
\hline MN05 & 17 & 0.4 & 30 & $<10$ & 0.81 & 0.9 & 0.2 & 2 & 2 & $<0.1$ & 0.150 & 4.20 & 6.0 & $<6$ & $<3$ & 0.230 & 0.165 & 22.0 \\
\hline MN30 & $<4$ & 0.2 & 23 & $<10$ & 0.82 & 0.9 & 0.2 & 1 & 3 & $<0.1$ & 0.360 & 3.60 & 5.7 & $<6$ & $<3$ & 0.159 & 0.154 & 24.0 \\
\hline MN26 & $<4$ & 0.1 & 2 & $<10$ & 0.09 & 0.1 & $<0.2$ & $<1$ & 1 & $<0.1$ & 0.087 & 0.63 & 2.5 & $<6$ & 6 & 0.043 & 0.039 & 0.9 \\
\hline MN25 & $<4$ & 0.1 & 3 & $<10$ & 0.10 & 0.1 & 0.3 & 1 & 2 & $<0.1$ & 0.360 & 0.70 & 3.5 & $<6$ & 12 & 0.039 & 0.034 & 3.4 \\
\hline MN13A & 34 & $<0.1$ & 9 & $<10$ & 0.33 & 0.3 & $<0.2$ & 2 & $<1$ & $<0.1$ & 0.120 & 0.88 & 3.0 & $<6$ & 3 & 0.058 & 0.046 & 15.0 \\
\hline MN13B & 32 & $<0.1$ & 9 & $<10$ & 0.19 & 0.7 & $<0.2$ & 9 & 2 & $<0.1$ & 0.110 & 1.10 & 3.1 & $<6$ & 7 & 0.065 & 0.082 & 10.0 \\
\hline MN1 3C & 35 & 0.1 & 17 & $<10$ & 0.47 & 0.6 & 0.3 & 3 & 9 & $<0.1$ & 0.150 & 3.20 & 5.4 & $<6$ & 50 & 0.132 & 0.120 & 27.0 \\
\hline MN27 & $<4$ & $<0.1$ & 4 & $<10$ & 0.10 & 0.1 & $<0.2$ & 2 & 1 & $<0.1$ & 0.110 & 0.59 & 2.4 & $<6$ & 4 & 0.026 & 0.028 & 1.1 \\
\hline MN33 & $<4$ & $<0.1$ & 13 & $<10$ & 0.46 & 0.6 & 0.2 & 2 & 12 & $<0.1$ & 0.240 & 3.00 & 5.1 & $<6$ & 39 & 0.107 & 0.115 & 16.0 \\
\hline MNO4 & 19 & 0.6 & 49 & $<10$ & 0.84 & 1.0 & 0.3 & 1 & 2 & $<0.1$ & 0.180 & 5.90 & 6.6 & $<6$ & $<3$ & 0.292 & 0.212 & 34.0 \\
\hline MN28 & $<4$ & 0.6 & 43 & $<10$ & 0.80 & 0.9 & 0.3 & 2 & 4 & $<0.1$ & 0.180 & 4.40 & 6.4 & $<6$ & 12 & 0.265 & 0.177 & 30.0 \\
\hline MN22 & 36 & 0.1 & 11 & $<10$ & 0.91 & 0.9 & 0.2 & 5 & 4 & $<0.1$ & 0.120 & 3.30 & 4.3 & $<6$ & 9 & 0.148 & 0.139 & 19.0 \\
\hline MN19 & 33 & 0.1 & 5 & $<10$ & 0.23 & 0.3 & $<0.2$ & 6 & 3 & $<0.1$ & 0.094 & 1.20 & 2.6 & $<6$ & 5 & 0.070 & 0.053 & 5.3 \\
\hline MN10 & 22 & 0.2 & 26 & $<10$ & 0.37 & 0.6 & $<0.2$ & 2 & 2 & $<0.1$ & 0.110 & 2.90 & 5.6 & $<6$ & $<3$ & 0.144 & 0.118 & 16.0 \\
\hline MN34 & 6 & 0.3 & 21 & $<10$ & 0.38 & 0.6 & $<0.2$ & $<1$ & 2 & $<0.1$ & 0.330 & 2.60 & 5.9 & $<6$ & 7 & 0.127 & 0.105 & 14.0 \\
\hline MN14 & 31 & 0.3 & 18 & $<10$ & 0.53 & 0.8 & 0.2 & 1 & 1 & $<0.1$ & $0.1 \cdot 70$ & 3.00 & 4.9 & $<6$ & $<3$ & 0.134 & 0.130 & 30.0 \\
\hline MNO3 & 16 & 0.7 & 49 & $<10$ & 0.98 & 1.1 & 0.2 & 2 & 1 & $<0.1$ & 0.280 & 6.60 & 8.5 & $<6$ & $<3$ & 0.361 & 0.234 & 41.0 \\
\hline MN06 & 21 & 0.4 & 45 & $<10$ & 0.85 & 0.8 & 0.2 & 3 & 1 & $<0.1$ & 0.210 & 5.60 & 7.7 & $<6$ & 41 & 0.242 & 0.184 & 27.0 \\
\hline MN23 & $<4$ & 0.2 & 19 & $<10$ & 0.65 & 0.9 & $<0.2$ & 12 & 2 & $<0.1$ & 0.110 & 3.50 & 4.3 & $<6$ & 4 & 0.130 & 0.143 & 18.0 \\
\hline MN15 & 28 & 0.5 & 40 & $<10$ & 0.47 & 0.8 & 0.3 & 2 & 1 & $<0.1$ & 0.390 & $3 .-90$ & 8.9 & $<6$ & 12 & 0.235 & 0.153 & 20.0 \\
\hline MN29 & $<4$ & 0.4 & 30 & $<10$ & 0.46 & 0.8 & 0.3 & 2 & 4 & $<0.1$ & 0.160 & 3.50 & 6.4 & $<6$ & 18 & 0.191 & 0.146 & 22.0 \\
\hline MNO9 & 23 & 1.4 & 16 & $<10$ & 1.10 & 1.2 & 0.2 & 3 & 1 & $<0.1$ & 0.680 & 9.70 & 17.1 & $<6$ & $<3$ & 0.632 & 0.308 & 64.0 \\
\hline MNO2 & 11 & 1.3 & 47 & $<10$ & 0.73 & 1.0 & 0.3 & 2 & 1 & $<0.1$ & 0.79 & 9.7 & 19.5 & $<6$ & $<3$ & 0.686 & 0.295 & 66.0 \\
\hline MN18 & 29 & 0.3 & 31 & $<10$ & 0.73 & 1.0 & $<0.2$ & 3 & 2 & $<0.1$ & 0.23 & 3.5 & 6.5 & $<6$ & 5 & 0.192 & 0.153 & 22.0 \\
\hline MNO7 & 22 & 1.2 & 34 & $<10$ & 0.79 & 1.0 & 0.3 & 2 & 1 & $<0.1$ & 0.82 & 9.0 & 17.9 & $<6$ & $<3$ & 0.622 & 0.284 & 62.0 \\
\hline MNO1 & 14 & 1.2 & 91 & $<10$ & 0.29 & 0.6 & 0.6 & 6 & 2 & $<0.1$ & 0.82 & 4.0 & 27.6 & $<6$ & 8 & 0.749 & 0.134 & 32.0 \\
\hline MN08 & 12 & 2.4 & 31 & $<10$ & 2.00 & 2.5 & 0.8 & 5 & 1 & $<0.1$ & 1.21 & 41.0 & 66.9 & $<6$ & $<3$ & 1.887 & 1.064 & 169.0 \\
\hline MN16 & 36 & 3.4 & 4 & $<10$ & 0.95 & 1.4 & 0.5 & 2 & $<1$ & $<0.1$ & 2.61 & 29.0 & 81.2 & $<6$ & $<3$ & 2.405 & 0.722 & 188.0 \\
\hline MN24 & $<4$ & 0.6 & 38 & $<10$ & 0.61 & 1.0 & 0.3 & 2 & 33 & $<0.1$ & 0.17 & 4.6 & 8.9 & $<6$ & $<3$ & 0.276 & 0.190 & 28.0 \\
\hline MN32 & 4 & 0.5 & 34 & $<10$ & 0.59 & 1.0 & 0.2 & 1 & 4 & $<0.1$ & 0.19 & 4.4 & 8.6 & $<6$ & $<3$ & 0.242 & 0.179 & 32.0 \\
\hline MN17 & 36 & 3.2 & 57 & $<10$ & 2.30 & 2.4 & 0.7 & 6 & 2 & $<0.1$ & 1.71 & 47.0 & 68.1 & $<6$ & 26 & 1.885 & 1.187 & 250.0 \\
\hline
\end{tabular}


